https://theses.gla.ac.uk/

Theses Digitisation:

https://www.gla.ac.uk/myglasgow/research/enlighten/theses/digitisation/

This is a digitised version of the original print thesis.

Copyright and moral rights for this work are retained by the author

A copy can be downloaded for personal non-commercial research or study, without prior permission or charge

This work cannot be reproduced or quoted extensively from without first obtaining permission in writing from the author

The content must not be changed in any way or sold commercially in any format or medium without the formal permission of the author

When referring to this work, full bibliographic details including the author, title, awarding institution and date of the thesis must be given

Enlighten: Theses

https://theses.gla.ac.uk/

research-enlighten@glasgow.ac.uk 


\title{
EUCHARISTIC SACRIFICE AND THE PATRISTIC TRADITION IN THE THEOLOGY OF MARTIN BUCER I534-I546.
}

\author{
by \\ Nicholas James Thompson
}

Thesis submitted for the degree of

Doctor of Philosophy

at the University of Glasgow

Apliti:2000

(c) Nicholas Thompson 2000 
ProQuest Number: 10390794

All rights reserved

INFORMATION TO ALL USERS

The quality of this reproduction is dependent upon the quality of the copy submitted.

In the unlikely event that the author did not send a complete manuscript and there are missing pages, these will be noted. Also, if material had to be removed, a note will indicate the deletion.

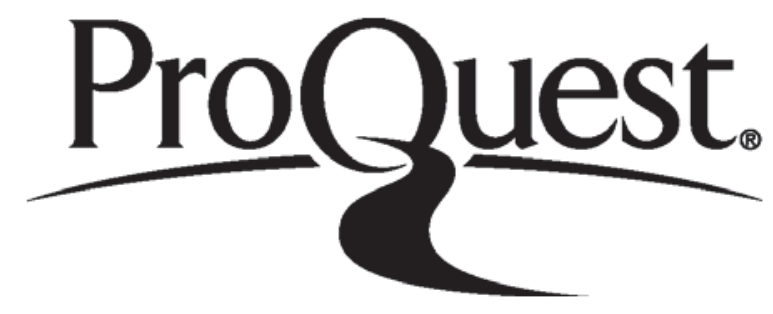

ProQuest 10390794

Published by ProQuest LLC (2017). Copyright of the Dissertation is held by the Author.

All rights reserved.

This work is protected against unauthorized copying under Title 17, United States Code Microform Edition (C) ProQuest LLC.

ProQuest LLC.

789 East Eisenhower Parkway

P.O. Box 1346

Ann Arbor, Ml 48106 - 1346 


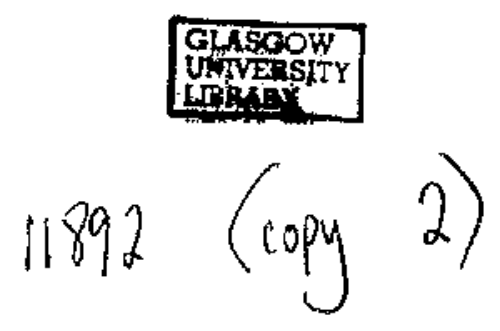




\section{ABSTRACT}

'I'he Reformation debate over eucharistic sacrifice threw the relationship betwecn Scripture and Tradition into sharp relief. While apologists for the stattus quo appealed to Scripture, they usually admitted that it could not be defended without an appeal to Tradition as well. For the Reformers, on the other hand, the "sacrifice of the Masses" epitonised the triumph of the human words and institutions over the Word of God. The Mass was replaced with new liturgies consistent with what the Reformers held to be a scriptural doctrine of the sacrament.

Martin Bucer is widely recognised as the "ecumenist" among the Reformers. His irenic activity was dirccted not only at securing unity within the Evangelical movement, but also at mending the divisions which the Reformation had opened in the wider European church. From 1534, Bucer sought to reassure adherents of the traditional church that Evangelical doctrine was consistent not only with Scripture but with the decrees of the councils and popes, the writing of the church fathers and even the scholastics. He sought as well to engage them in a joint reformation of the church based on the historical consensus ecclesiae.

This study assesses Martin Bucer's theology of eucharistic sacrifice in terms of this broader project. Its development is traced from his earliest published attack on the Mass in 1523, but the focus of the study is Bucer's writing between 1534 and 1546. This period covers his involvement in the Second Colloquy of Leipzig (1539) and the secret colloquy of Worms (1540). It also covers his involvement with Hernann von Wied's attempt to introduce the Reformation to the Archdiocese of Cologne in the wake of the First Colloquy of Regensburg (1541). Two works are considered here. The first is Constans defensio (1543): Bucer's response to the Antididagma (1543) in which the Cologne calhedral chapter attacked the archbishop's reform proposals. The second is Bucer's De vera et falsa caenae dominicae administratione (1546). In both Bucer appealed to the fathers. This time, however, he did so to distinguish his understanding of eucharistic sacrifice from that of Johannes Gropper, the Catholic theologian who had collaborated with him on the Worms-Regensburg Book. Their debate clarifies ambiguities in the articles on the Mass which emerged from the Colloquies. It also sheds light on Bucer's own undcrstanding of these articles.

During the era of the colloquies, Bucer seems to have been ready to countcnance the continued use of theithats tof the Roman rite in the Catholic territories of Germany, but subject to certann provisos. Firstly, the private Mass would be abolished. Secondly, congregational communion would be encouraged at 
public Masses. Thirdly, the Roman Canon would be subject to a "suitable interpretation," and the priests and people would be instructed in it.

The suitable interpretation would involve the following components. Firstly, the people would be warned against superstitious faith in the opus operatum. The opus operatum would be interpreted in terms of Bucer's later theology of sacramental efficacy: i.e. as the exbibitio of the body and blood of Christ and its faithful consumption. The "application" of Christ's sacrifice to non-communicants, living and dead would be understood as thanksgiving and intercession offered by Christ's members through, with and in Christ their head. The "merits" of the saints would be understood as their intercession for the church militant. "Offering" for the dead would be understood as the church's recognition of its communion with those who had died in Christ, and its hope to share with them in the resurrection.

While Bucer and Gropper failed to agree on the nature of Christ's presence in the eucharist, both agreed that, considered as a whole, the Last Supper fulfilled the types of the Old Testament sacrifices. It did so as realised memorial. In both God's past deeds were recalled with thanksgiving. Material goods were presented which "represented" both the people's thanksgiving and the fruits of God's action in the past. A portion of this offering was eaten in God's presence. A portion was set aside for the use of the poor. In both rituals, priest and people anticipated the completion of God's promises. For Israel, this fulfilment was Christ. For the church it was the perfect unity of Christ and his body. 


\section{TABLE OF CONTENTS}

1. INTRODUCTION.

2. THE PLACE OF 'TRADITION IN THE DEBATE ON THE

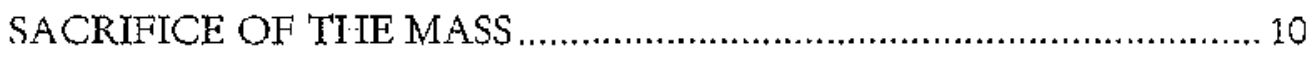

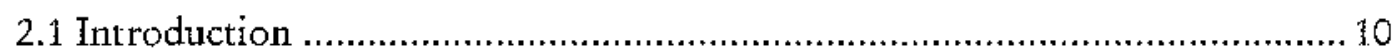

2.2 The Authority of Tradition on the Eve of the Reformation ........................ 13

2.2.1 Humanism as a complicating factor ................................................... 17

3. TIIE EARLY DEBA'TE ON THE SACRIFICE OF TTHE MASS ....................23

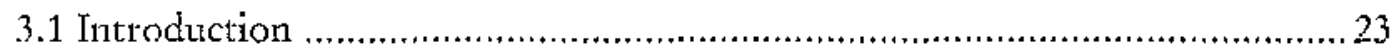

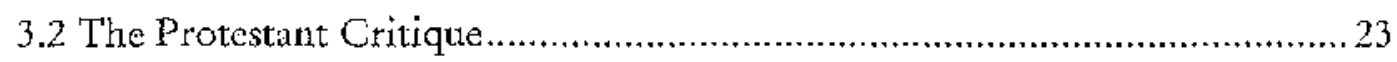

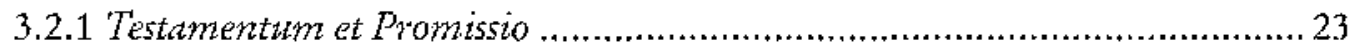

3.2.2 The Opus Operatum and its Application to Others................................ 24

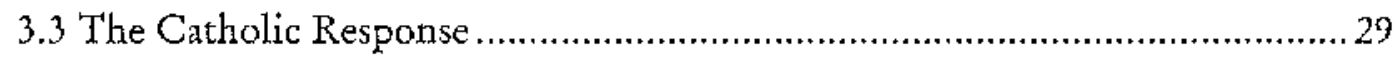

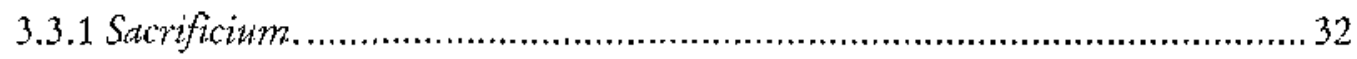

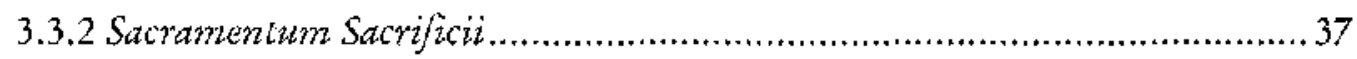

3.3.3 The Opus Operatum and its Application to Others................................ 42

3.3.4 T'he Historical Development of the Mass............................................... 48

3.3.5 The Memorial of the Faithful Departed and the Saints...........................51

4. THE USE OF TRADITION AMONG THE REFORMERS …......................55

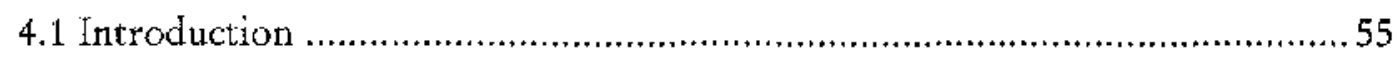

4.2 The Reformers' Use of the Fathers in the Debate on the Sacrifice of

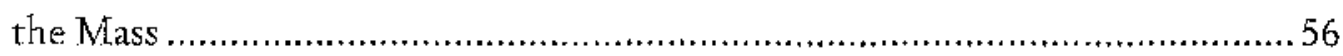

4.2.1 Questioning the Authenticity of the Authorities...................................56

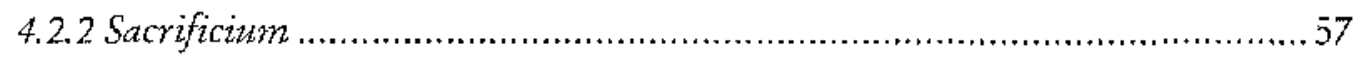

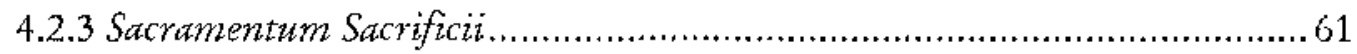

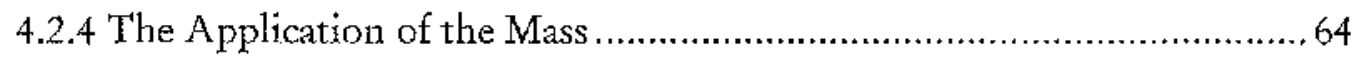

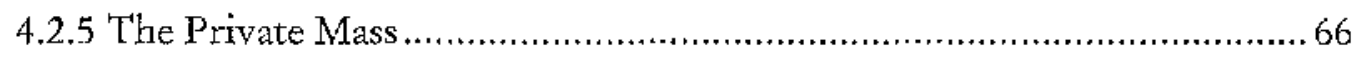

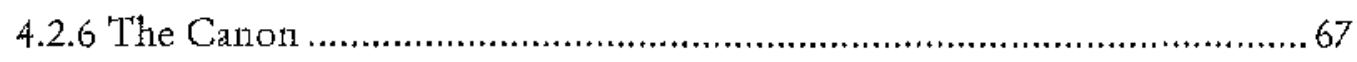

4.3 Summary: Eucharistic Sacrifice and Tradition in the Early

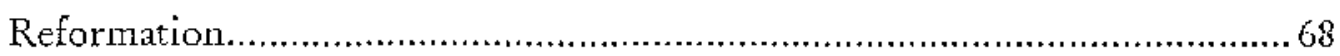

5. BUCER'S EARLY WRITING ON THE MASS: $1523-1531 \ldots \ldots \ldots \ldots \ldots \ldots \ldots \ldots . . . . . . \ldots 1$

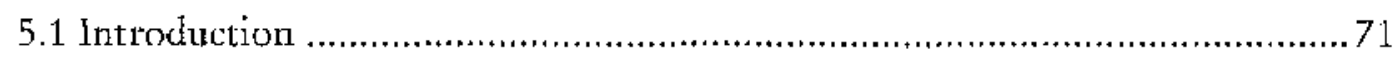

5.1.1 The Abolition of the Mass in Strasbourg ...........................................

5.1.2 From the Abolition of the Mass to the Early 1530 s.............................78

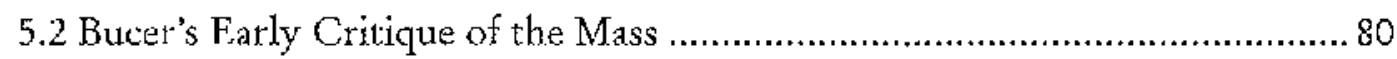

5.2.1 The Mutilation of the Divine Institution of the Sacrament .................... 80

5.2.2 The Ethical and Ecclesiological Dimensions of the Eucharist.................. 81 


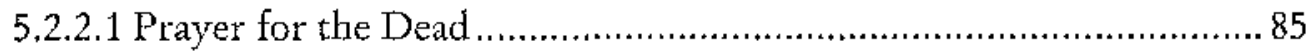

5.2.3 The Status of the Church's Liturgical 'T'radition ................................... 85

5.2.3.1 Christian freedom and the interior and exterior dimensions of

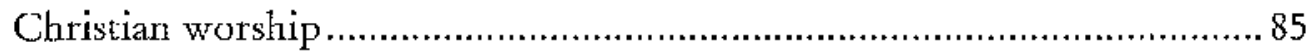

5.2.3.2 The Fucharistic-Sacrificial Tradition ............................................ 87

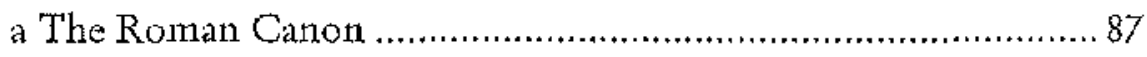

b The Indefectibility of the Church............................................. 89

c The Eucharistic-Sacrifical Vocabulary of the Fathers................. 91

d The Traditional Scriptural Texts .............................................92

5.3 Continuity hetween Bucer's Earlier and Later Approach ............................ 98

6. BUCER'S PREPARATIONS FOR A COUNCIL (1534-1540) .................... 101

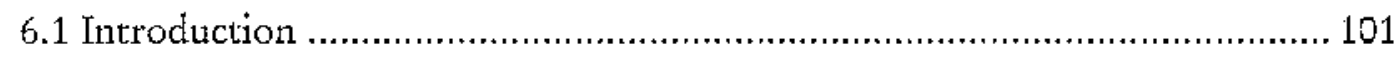

6.2 Evolution of the Idea of a Religious Colloquy ......................................... 102

7. CATIIOLIC IRENIC WRITING ON THE SACRIFICE OF THE

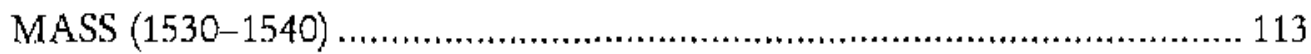

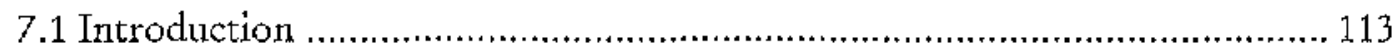

7.2 Augsburg 1530: the Committee of the Fourteen ……................................ 113

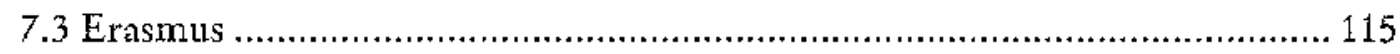

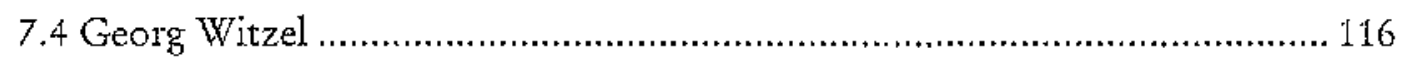

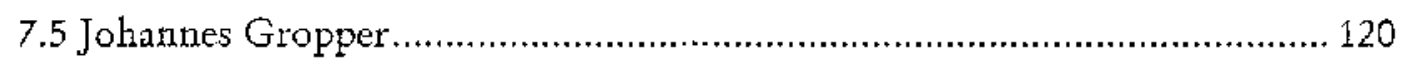

8. THE COLLOQUIES AND THE MASS (1539-1541) ................................. 131

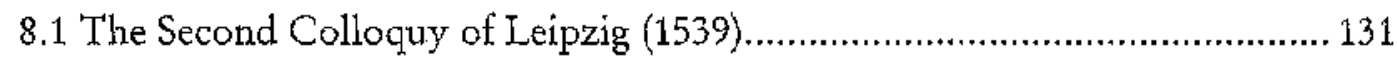

8.2 The Secret Colloquy of Worms (1540) and the Colloquy of

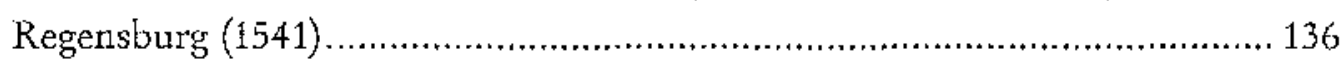

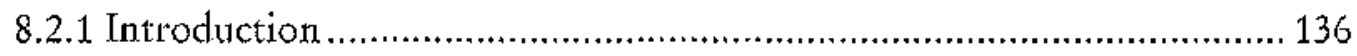

8.2.2 Article Fourteen: The Sacrament of the Eucharist.............................. 138

8.2.3 Article Twenty: Certain Dogmas Confirmed by the Authority of

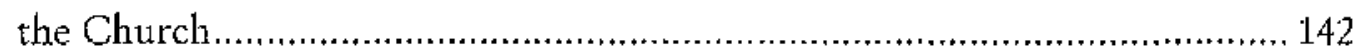

8.2.3.1 The Sacrifice of the Mass .............................................................. 144

a The First Offering: Christ .................................................... 145

b 'The Second Offering: The Church ......................................... 150

c The Third Offering: Praise ................................................. 155

d The Fourth Sacrifice: Bread and Wine.................................... 156

c The Roman Canon ............................................................ 158

8.2.4 Article Twenty-one: On the Administration of the Sacraments

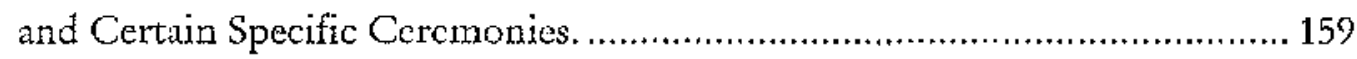

8.3 Summary: The Mass in the Era of the Colloquies ....................................... 163

9. THE AFTERMATI- OF THE FIRST COLLOQUY OF 


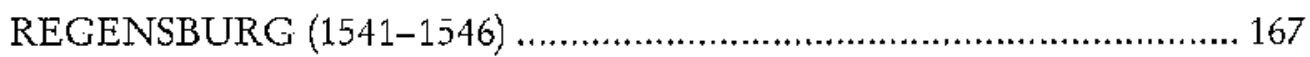

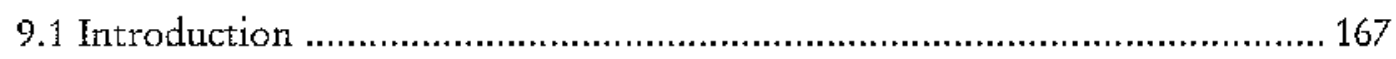

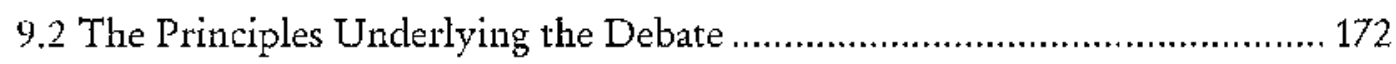

10. EUCIIARISTIC SACRIFICE IN CONSTANS DEFENSIO (1543) AND

DE VERA ET FALSA CAENAE DOMINICAE ADMINISTRATIONE

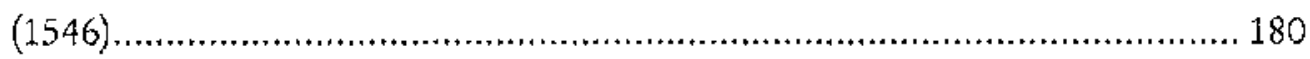

10.1 Structure of the Argument and Some Preliminary Observations............. 180

10.2 Causa Offerendi: the Rationale of Sacrifice............................................. 180

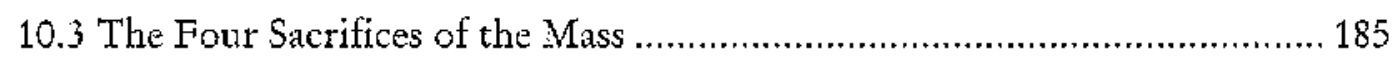

10.3.1 The Offering of Bread and Wine.................................................... 186

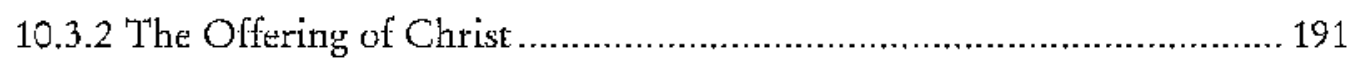

10.3.3 The Offering of the Church .............................................................205

10.3.3.1 The Opus Operatum and Its Application for Others ................... 205

10.3.4 The Offering of Tharkssgiving and Praise .........................................211

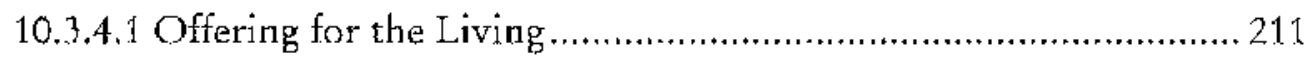

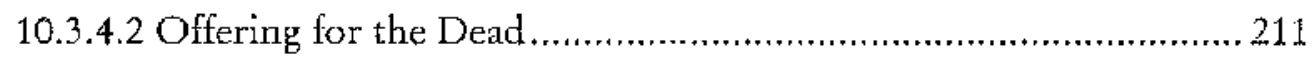

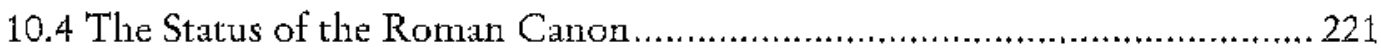

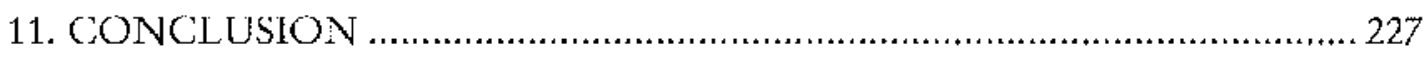

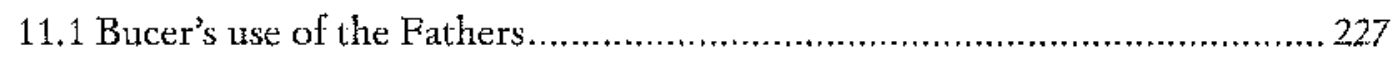

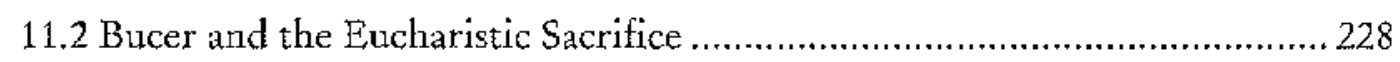

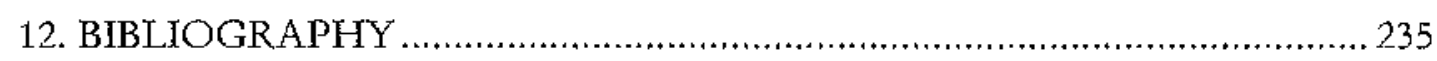

12.1 CON'I'EMPORARY PRINT'ED SOURCES AND PRIMARY

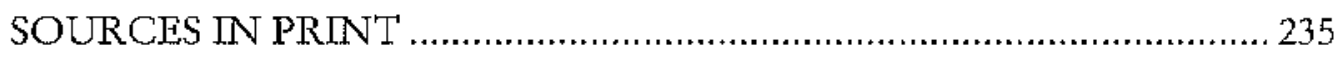

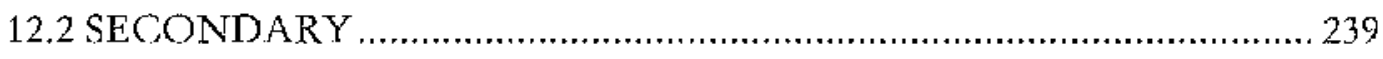


To Mum and Dad

who first made bistory and theology fascinating $\mathrm{cs}$ 


\section{FOREWORD}

Every submitted thesis carries with it a debt of gratitude. "Thanks, first of all, to Dr Ian Hazlett for his expert guidance, but also for his great kindness and hospitality. One is fortunate to find the first in a supervisor, but the second two are supererogatory. Thanks, also to the staff and students of the Faculty of Divinity for the welcome they have extended to me during my time in Scotland. Thanks, finally, to my extended family and wonderful friends, sine quibus non.

Nick Thompson, Palm Sunday, 2000. 


\section{KEY TO ABBREVIATIONS}

ACA Apologia Confessionis Augustande:

Allen Opus Epistolarum Desiderii Erasmi. Edited. by P.S. Alleı, 12 v. Oxford, 1906-1958.

ARC Acta Reformationis Catbolicae ecclesiam Germaniae concemantia saeculi XVI. Edited by G. IPfeilschitter. 6 v. Regensburg, 1959-1974.

BCor Correspondance de Martin Bucer. Vol 1-. Leiden, 1979-

BDS Martin Bucers Deutsche Schiften. Vol. 1-. Guttersloh, 1960-

BS Die Bekenntnisschriften der ev-lutherischen Kirche. Edited by Dentscher Evangelischer Kirchenausschuß. 8th ed. Götingen, 1979.

BOL Martini Buceri Opera Latina. Vol. 1-. Paris, 1954-; Leiden, 1979-

CA Confessio Augustana

CCA Confutatio Confessionis Augustanae

CCath Corpus Catholicorum

CCL Corpus Christianorum. Series Latinat

CR Corpus Reformatortm

Crabbe Concilionum omnizm tam generalium. Edited by P. Crabbe, 3 v. Cologne, 1551.

CSEL Corpusscriptortam ecrlesiasticonam latinorum

CT Concilium Tridentinum: diariorum, actortum, epistularum, tractarum nova collectio. 13 v. Freiburg i. Breisgau, 1901-1938.

DS Lacbiridion symbolorum et definitionum de rebus fidei el morm. Edited by l-1. Denziger \& A. Schönmetzer. 26th ed. Freiburg i. Breisgau, 1976.

Friedberg Corpus iuris canonici. 2 v. Edited by A. Friedberg. Leipzig, 1879. reprint Graz, 1959.

KT'R Katholische Theologen der Reformationszeit. Edited by E. Iserloh. Vol. 15. Münster, 1975-

InE Desiderius. Desiderii Erasmi Roterodami opera omnia emendationa et aucioma... $10 \mathrm{v}$. Leiden, 1703-1706.

Lenz Briefruechsel Landgraf Philipp's des Grossmütbigen von Hessen mit Bucer. 3 v. Edited by M. Lenz. Leipzig, 1880 1881.

Mansi Sacronm concilionum nova et amplissina collectio. Edited by J. Mansi. 53 v. Florence; Paris, $1759-1927$.

Oberman \& Courtenay Gabrielis Biel Canonis Misse expositio. Edited by H. Oberman \& W. Courtenay. 4. v. Wicsbaden, 1963-1967.

PG Migne, Patrologiae cursus completus. Series Gracca. 162 v, Edited by J. P. Migne. Paris, 1857-1866.

PL Migne, Patrologiae cursus completus. Series Latina. 221. v. Edited by J. P. 
Migne. Paris, 1844-1864.

RST Reformationsgeschichtiche Studien und Texte

Schicss Briefwechsel der Brider Ambrosius und Thomas Blaurer 1509-1548. Edited by 'T. Schieß3. 3 v. Freidburg i. Br., 1908-1912.

Stupperich "Bibliographia Buccriana" in II. Bornkanm, Martin Bucers Bedeutung fiur die europäische Reformationsgeschichte, 37-96. Gütersloh, 1952.

SVR Schriftendes Vereinsfür Reformationsgeschichte

SMRT Studies in Medieval and Reformation Thought

ST Summatheologiae

VIEGM Veröffentlichungen des Instituts für Europizische Gescbichte, Mainz

WA D. Martin L.wthers Werke: kritische Gesamtausgabe, 72 v. Weimar, 1883-

WABR D. Martin Luthers Werke: kritische Gesamtsugabe: Briefwechsel. 16 v. Weimar, 1930

Werbeck \& Hofmann Collectoriwm circa quattuor libros 'Sententiamm.' Edited by Wilfridus Werbeck \& Udu Hofmann, 5 v. 'l'übingen, 1975.

7.kTh Zeitschrift fïr katholische Theologie. 
Si ergo vos estis corpus Christi et membra, mysterium vestrum in mensa Dominica positum est: mysterium vestrum accipitis. Ad id quod estis, "Amen" responderis, et respondendo subscribitis. Audis enim, "corpus Christi," et respondes, "Amen," Esto membrum corporis Christi, ut verum sil Amen.

Augustine, Sermo 272 ad infantes de sacramento.

Vt vero nunquam dum hic vivimus, plena est in nobis ista communio Christi et vita eius (nunquan enim est ille in nobis omnia, et nos omnia in eo sumus) ita semper quaerendum et expetendum nobis est, ut ille magis magisque sit in nobis, $\&$ nobis in illo.

Bucer, In sacra quatuor evangelia. 


\section{INTRODUCTION.}

When reference is made to the eucharistic controversies of the Reformation, it is usually the debate over Christ's sacramencal presence which is meant. The Reformers rejected transubstantiation as an authoritative or even suitable description of that presencc. They were unable, however, to agree on an alternative. 'I'he Sacramentarian Controversy ensued.

Despite this, the Reformers were unanimous in tejecting a number of other aspects of received eucharistic doctrine. According to Luther, the gravest of these was the belief that the Eucharist was a good work and sacrifice, "offered" and "applied" by the church's priesthood for the sins of the living and the dead. I.uther regarded this not only as a perversion of the Gospel, but as the mainstay of the whole penitential complex of the mediaeval church: Purgatory, indulgences, pilgrimages, chantries, fraternities, and so forth.

Martin Bucer's efforts to secure sacramental concord among the Reformers are well known and have been studied in detail. ${ }^{.}$Some attention has also been paid to his efforts to reach an agreement on the eucharistic presence with the Catholics in the religious colloquies between 1539 and $1541 .{ }^{2}$ Marijn De Kroon has written on Bucer's treatment of the eucharistic sacrifice in his Psalms commentary (1529). De Kroon argues that Bucer's remarks on the subject in the commentary were calculated to win Evangelical eucharistic theology a sympathetic hearing at the French court. However, he is mostly interested in the implications of these remarks for the Sacramentarian Controversy. Beyond this study, neither Bucer's theology of eucharistic sacrifice nor his irenic activity on the matter have received more than passing mention. ${ }^{3}$

1 Eells, "The Genesis of Martin Bucer's Doctrine of the Lord"s Supper," Princeton 7 theological Review 23 (1925):213-233; Hazlett, The Development of Martia Bucer's Thinking on the Siacrament of the Lord's Suppter in its Historical and Theological Conlext (Dr theol. diss, University of Miinster, 1975); "Zur Ausiegung von Johannes 6 bei Bucer während der Abendmahlskontroverse" in Bucer und seine Zeit (Wiesbaden, 1976), 74-87; Kaufmann, Dir Abendmablistheologie der Straf3burger Reformatoren bis 1528 (Tübingen, 1992); "Streittheologie und Friedensdiplomatie: die Rolle Martin Bucers im Frühen Abendmahlsstreit," in Marin Bucer and Sixteentb Century Lurope, ed. Krieger (Leiden, 1993) 1:238-256; Kittelson, "Martin Bucer and the Sacramentarian Controversy: the Origins of his Policy of Concord," $A R G 64$ (1973):166-183.

${ }^{2}$ Kretschmar, "Realpräsenz und Transubstantiation: der Reichstag von Regenshurg 1541 und ökumenische Konsensusdokumente der Gegenwart," in Praesentia Christi: Festschrift Johamnes Betz zwm 70. Geburtstag dargebracht von Kollegen, Freanden, Schülern, (Düssclioror), 1984), 208-239; Mehlhausen, "Die Abendnahlsformel dos Regensburger Buches," in Studien zur Geschichle und Theologie der Reformation: Festschrift für Emst Bizer (Neukirchen-Vluyn, 1969), 182-211; Fraenlsel, "Les Frozestants et le problème de la transubstantiation au Colloque du Ratisbonne: documents et arguments, du 5 au 10 mai 1541," Oectmenica 3 (1968):70-116.

${ }^{3} \mathrm{De}$ Kroon, "Bemerlkungen Martin Bucers über das Abendmahl in seinem Tsalmenkommentar von 1529," in Bucer und seine Zeit (Wiesbaden, 1976), 88-100. Iserloh, "Der 
Assuming that Bucer shared the Reformers' rejection of the Catholic position, this may not seem surprising. What had Bucer to say that Luther, Zwingli or Melanchthon had not already said? Yct in 1539 at the second Colloquy of Leipzig, in 1540 in a secret colloquy at Worms, and in 1541 at the first Colloquy of Regensburg, Bucer collaborated with Catholic theologians in producing common statements on a number of disputed doctrines, including sacrifice of the Mass. In his Consilium theologicum (c1540) Bucer commented that the antichrists' "godless persuasion" about the Mass did not reside in the words of the Mass itself, or in the practice of the fathers, the decrecs of the pontiffs and councils, or the teaching of the scholastics. From the first Colloquy of Regensburg in 1541 we have the vague, but nonetheless intriguing remark of the papal nuncio that Bucer had professed himself ready to "admit" the Roman Canon. "This prima facie evidence should at least pique our curiosity as to what Bucer imagined he was doing during this period.

Mediaeval commentary on the Mass assumed that the lex orandi determined the lex credendi. The Rcformers' Catholic opponents conceded that, while the substance of their eucharistic theology had its foundation in Scripture, there were aspects of the Mass (stsch as the Roman Canon) which had no explicit Scriptural warrant. They argued, however, that the liturgical practice of the church and testimony of the fathers were also authoritative sources of catholic doctrine. 'The Reformers' insistence on the primary and normative rolc of Scripture meant that, in principle at least, they were not bound to answer such claims. All they had to show was that the Catholic reading of Scripture was erroneous or inconclusive, and their case was proven. Yet it is clear that the Reformers did make use of patristic authorities. Why should this have been the case?

The development of Bucer's attitude toward the reccived doctrine of eucharistic sacrifice is interesting because it was so evidently the product of his developing views on the relationship between Scripture and Tradition. During the period of the colloquies with the Catholics, Bucer would appeal to an historical consensts ecclesiae - contained in the writing of the fathers, the councils, and the decretals - as the basis for a single German church, uniting both Catholic and Evangelical, and retaining many traditional structures and liturgical practices.

The religious colloquies have an appeal for an ecumenical age. The First Colloquy of Regensburg has attracted particular attention because of its short-lived agreement on justification: Luther's articulus stantis vel cadentis eccleside. ${ }^{3}$ Calvin was

Wert der Messe in der Dislsussion der Theologen vom Mittelalter bis zum 16. Jahrhundert," ZkTh 83 (1961):77..79 mentions the treatment eucharistic sacrifice in the Worms-Regensburg Book.

${ }^{1}$ For both passages, see below p. 143, 149.

${ }^{5}$ Luther, Schralkaldic articles (WA 50:198-200). The major monographic work on the 
able to stand back and marvel at what the Catholics appeared to have conceded. 6 Bucer, however, engaged in the risky business of doctrinal negotiation with representatives of a church he believed to be in subjection to Antichrist. His efforts attracted suspicion and bewilderment from both sides of the religious divide. He was accused, both then and subsequently, of masking genuine differences with vague and misleading formulae; of seeking unity at any cost; of letting personal relationships dull his theological acuity; of subordinating doctrinal questions to moral ones.?

However, a number of writers on Bucer have attempted to identify the theological basis of Bucer's hopes and activity during the colloquies. Peter Matheson thinks that some of his statements at the time were purely strategic: "on occasion, [Bucer] could offer far-reaching concessions which he never meant to accede to, but pinned them to conditions he knew the other side could not fulfill either, in order to put them on the defensive." However, Matheson is one of a number of scholars who have drawn attention to Bucer's conviction that there were "members of Christ" existing in the midst of the church of antichrist." Some of these werc convinced Evangelicals. Unable to flee or embrace martyrdom, they had adopted the pragmatic policy of Nicodemism: inward dissent concealed under outward conformity to the rites of the traditional church. However, a greater number of these members of Christ's body remained in the papal church by choice. They admitted the need for reform, but claimed that by acting unilaterally, the Reformers had damaged the substance of the Christian faith and had ruptured the bonds of charity which bound the church together. Bucer's insistence that love is

colloquies is still Augustijns, Te Grodsdienstgesprekken tussen Rooms-Katholieken en Protestanten van 1538 tot 1541 (Haarlem, 1967). See also his "L'Esprit d'Érasme pendant le colloque de Worms (1540)," in Colloquia Frasmiana Turonensia, ed. Margolin (Toronto, 1972) 1:381-396; "Bucer und die Religiongespräche von 1540/41," in Martin Bucer and Sixtcenth Century Eturope, ed. Krieger, 2:671680; "Die Religionsgespräche der vierziger Jahre," in Die Religionsgespräche der Reformationszeit, ed. (i. Müller, (Gütersloh, 1980) 43-53; "Butcer's Ecclesiology in the Colloquies with the Catholics," in Martin Bucer: Reforming Church and Community, ed. Wright, 107-121; Pfnür, "Die Eingigung bei den Religionsgesprächen von Worns und Regensburg, 1540/41: eine Täuschung?" in Die Religionsgrsprüache der Reformationszeit, ed. Müller, 55-88. SVR, 191. Gütersloh, 198C. Zur Mühlen, "Martin Bucer und das Relionsgespräclı von I Iagenaau und Worms, 1540/41," in Martin Bucer and Sixteentb Centutry Europe, ed. Krieger, 2:658-669; Peter Marheson's Cardinal Contarini at Regensburg (Oxford, 1972), 1972 is still the most substantial Linglish work on the subject.

${ }^{6} \mathrm{CR} 39: 215$.

7 For an account of contcmporary and subsequent assessments of Bucer's ecumenical activity, see Wright, "Martin Bucer: Ecumenical 'I'heologian," in Common Places of Marim Rucer (Appleford, 1972), 47-52. See also, Friederich, "Martin Bucer - Ökumenc im 16. Jahrhundert," in Martin Bucer and Sixteenth Centtry Europe, ed. Kricger, 239-255.

"Matheson, "Martin Bucer and the Old Church," in Martin Bucer: Reforming Church and Community, ed, Wright, (Cambridge, 1994), 10, n. 59.

"See also Augustijn, "Bucer's Ecclesiology"; Mathcson, "Martyrdom or Mission: a Protestant Debate," ARG 80 (1989): 154-171; Higman, "Buccr at 1es Nicoderrites," in Martin Bucer and Sixteenth Century Europe, ed. Kricger, 2: 645-658. 
expressed and exercised "for others," is frequently remarked upon. His attitude toward this latcer group was dictated by his belief that Christian love involved a duty of care towards the "weaker brethren." Nicodemism was no longer a merely pragmatic arrangement but an opportunity for mission. The "saints" were called to make themsclves all things to all people, in order to draw as many as possible, step by step, to the fullness of the truth. The concessions made to the Catholics in the era of the colloquies have to be understood in this light.

Gottfried Hammann notes that the motifs of "progress" and "increase" in effective faith are as important to Bucer's ecclesiology as they are to his understanding of the justification of the individual. ${ }^{\circ}$ While the true church was founded on faith in Christ, the communion of his members among themselves and with Christ was never fully perfected. Bucer did not regard this communion as an invisible reality only. It had to be actualised and exercised in the life which members of the mystical body lived with one another and for one another. Hammann draws attention to the implications this had for the development of Bucer's theology of the church's ministry in the 1530s. Against the Strasbourg Anabaptists, Bucer insisted that the ministry of the cliurch had the right to institute laws, ordinances and doctrines which had no express Scriptural warrant (e.g. infant baptism). ${ }^{11}$ Such "unwritten laws" must not be repugnant to Scripture. However, where they were introduced to edify the Body of Christ in faith and love, they were evidence of the work of the Holy Spirit. Augustijn argues that Bucer's appeals to fathers, canons and decretals during the era of the colloquies has to be seen in this light as well. Tradition was not only a way of luring "weak" traditionalist brethren back to the splendour of the Gospel. It is also an expression of Bucer's genuine esteem for those rites and observances which he believed had been introduced to the church in previous generations in order to build it up it in faith and love. Such structures were also in order to preserve and promote the unity of the present church. Iven if the "traditions" inherited from the past did not presently serve the purpose for which they had been intended, it might be possible to renew then rather than abolish them altogether. ${ }^{12}$ Bucer's approach to the traditional church is sufficiently explained neither as accommodation of the weals nor as simple respect for historical continuity and the consensws ecclesiae. His activity in the era of the colloquies involves a mixture of the two. In all cases, his principal concern was to pursuc the course of action which, in the circumstances, seemed most likely to lead to the edification of the church in faith and love.

${ }^{10}$ Hammann, Entre lat secte et cité: le projet d'église du reformateur Martin Bucer (1491-1555) (Geneva, 1984), 36-37

${ }^{11}$ Ibid., 125-127.

${ }^{12}$ Augustijn, "The Colloquies with the Catholics," 114-118. 
But what of the eucharistic sacrifice itself? At Regensburg, the doctrines of justification and cucharistic presence were the subject of long and arduous negotiation. 'Though the Colloquy agreed on the former it collapsed after failure to agree on the latter. By the time it came to the debate on the sacrifice of the Mass, both sides had retreated into their entrenched positions. Counter-articles were submitted after a day's debate. No agreement was reached. This appears to confirm Francis Clark's assessment of the Reformation debate on the eucharistic sacrifice. Clark locates the source of the Reformers' hostility towards the Mass in their antipathy toward what he describes as an "incarnational" theology of sacramental mediation and co-operation. ${ }^{13}$ For Clark, the opposition between the two positions is summed up in the phrase: ex opere operato; the belief that fruits of Christ's onceand-for-all sacrifice are communicated, through the very performance of the eucharistic rite, to those who place no hindrance in their way. ${ }^{1+}$ As we shall see, both Eck and Melanchthon identified the opzts operatum as fundamental to the dispute between them: what was the relationship between the "work" of Christ and the "work" of the church; between Calvary, and the daily "sacrifice" of the Mass? However, in a letter to Melanchthon, Eck would describe this as a question to be left to a general council. ${ }^{15}$ This remark suggests the aptness of Basil Hall's warning against judging the colloquies with hindsight shaped by confessionalisation. ${ }^{16}$ Both sides of the Reformation debate were aware that their differences on the Mass ran particularly deep. Eucharistic sacrifice, however, had never been the subject of a formal conciliar definition, and it is clear that theologians on both sides believed that the Tradition allowed room for negotiation on certain questions.

Following the negotiations at the Diet of Augsburg in 1530, a number of Catholic writers sought to explain the Mass in a way which would make it more palatable to an audience - Catholic and Evangelical -- dismayed by superstitions and abuses associated with its celebration. Georg Witzel sought to distinguish the substance of the Eucharistic tradition from what he believed were later and inessential accretions (e.g. the private Mass). Johannes Gropper attempted to explain Eucharistic sacrifice in a way which minimised the alleged conflict between the Mass and justification by faith. Both might pass as examples of Bucer's "weaker brethren," but I believe there is more to the rapprochement between Bucer and the two men than this.

In what is still a definitive study of the mediaeval theology of eucharistic

${ }^{13}$ Clark, Eucharistic Sacrifice and the Reformation, 2nd ed., (Oxford, 1967), 103.

${ }^{14} \mathrm{Ibid}$.

${ }^{15}$ See below, ch. 6-7.

${ }^{16}$ Hall, "Colloquies between Catholics and Protestants," chap in Humanists and Protestants (Edinburgh, 1990), 144. 
sacrifice and its relationship with the Reformation, Erwits Iserloh has distinguished between two accounts of the opus operalmm." One saw the priesthood and sacrifice of Christ, present sacramentally, as the constituitive sacrifice of the Mass. Here the opus operatum was analogous with the confection of the other sacraments: in the consecration, the church's minister, acting ex persona Cbristi, made Christ's sacrifice present. The other account saw Christ as the victim offered the Mass, but also sought to identify a delegated priestly and sacrificial character in some act of the church's minister outside the consecration. This second account required two opera operata: the consecration performed by the priest ex persona Cbristi and an offering performed ex persona eccleside.

Clark has demonstrated the universal insistence on the Catholic side that the Mass was not an attempt to repeat or supplement Calvary, and that the victim in both cases was one and the same. He has also demonstrated that the Reformers" opposition to the Mass was not a result of the abuses and misunderstandings with which previous generations of Anglo-Catholic scholars had sought to excuse their forebears. ${ }^{18}$ However, Bucer's negotiations with the Catholics suggest that the Reformers understood the reccived doctrine of Eucharistic sacrifice in terms of Iserloh's second paradigm. They were not, however, opposed in an unqualified way to the ecclesial and sacramental mediation of grace. This was particularly true of the Wittenberg Reformers. In the early part of the Sacramentarian Controversy, Bucer ayreed with the Swiss Reformers that the sacraments wcre signs of spiritual realities, but not effective signs. In 1530s, however, he emphasised the "exhibitive" function of the sacraments: through the tnio sacramentalis word and sacrament became the normal and habitual instruments by which the Holy Spirit conveyed what they signified to the faithful, whether worthy or not." Where the encharistic sacrifice was articulated on the Catholic side in terms of Iserloh's first paradigm, then Bucer saw room for rapprochement.

Bucer would never agree with his Catholic counterparts that Christ had instituted an offering of his body and blood in the Last Supper. Agreement was also frustraled by Catholics insistence on transubstantiation for at least, substantial conversion) and by Bucer's equally resolute refusal to accept this. However, where the two sides examincd the institution of the Eucharist in broader terms, particularly as memorial and thanksgiving, there was room for rapprochement. Melanchthon had claimed that sacrament and sacrifice were mutually exclusive. Bucer, however, believed that tcstament, covenant, sacrament and sacrifice

\footnotetext{
${ }^{17}$ Iserloh, "I)er Wert," 44-79.

${ }^{18}$ Clark, 92-94 8c passim.

1. HJammann, 115.
} 
bclonged to the broader genus of "ceremonies" which obtained under both the Old and New Testaments. T'hus, whether foedus or sacrificium was the catcgory used to explain the Last Supper, both sides agreed that the rite was the sacramental means through which the faithful becanc what they already were in mysterio: the perfect unity of head and members won through Christ's sacrifice on the cross. In this contcxt, Bucer recognised the legitimacy of a memorial of the saints and of the faithful departed. It would lead him to acknowledge that in a qualified sense, the Mass could be "applied" to others who were not present. It would also lead him to admit that the Roman Canon had once possessed an "edifying" seinse.

My purpose in this study is not to assess the adequacy of either side's understanding of the church's eucharistic tradition. Nor is it to make any judgement about the compatibility of Protestant and Catholic eucharistic theologies in the present day. It is to describe and analyse the way in which Bucer and his adversaries appealed to a common encharistic tradition both in the religious colloquies and in their immediate aftermath. There can be no doubt that the project of the colloquies involved ambiguities and misapprehension. Clark's analysis has much to offer in terms of its broad strokes, but the ultimate failure of the colloquies and the subsequent hardening of confessional positions should not cause us to overlook the detail of what was in fact agreed on the way.

'The focus of this study is Bucer's writing between 1534 and 1546. It is in this period that we see a change, or perhaps better, a development in Bucer's attitude toward the traditional church and the sacrifice of the Mass. Becausc this pcriod sces both the waxing and the waning of his hopes for the restoration of church unity, it will allow us to assess what aspects of Bucer's approach to the Mass were consistent and what were tactical or contingent. In order to demonstrate that there was in fact some kind of devclopment, this is preceded by a survey of Bucer's treatment of eucharistic sacrifice between 1523 and 1531 .

Chapter Two examines the status of the authority of 'Tradition on the eve of the Reformation. It also looks in greater detail at tension between Scripture and Tradition in the early Reformation debate on the Mass.

Chapters Three and Four attempt to identify the scriptural and patristic commonplaces used in the early Reformation debate on the Mass. As Anthony Lane observes, citations of fathers are not to be confused with modern footnotes. ${ }^{20}$ We cannot assume in other words, that a patristic citation comes directly from an edition or manuscript of the father's work. As chapters two and three will indicate, much of the material used by the Rcformers and their opponents came to them by way of florilegid, text-books and commentaries such as the Decretum Gratiani,

\footnotetext{
${ }^{23}$ Lane, John Calvin: Student of the Cburch Fathers, (Edinburgh, 1999), 1.
} 
Lombard's Sentences, and Biel's Sacri canonis missae expositio. Where a citation occurs in a commonly available mediaeval text, I have noted the fact both here and in subsequent chapters. This does not mean, of course, that any of these collections was necessarily the immediate source to which a polemicist turned. In many cases it is difficult to establish whether a writer obtained a citation directly from the writing of the father in question, from his opponents or from the work of another Reformer. In the following cases I have attempted to identify the inmediate sources of citations used by Bucer and his contemporaries: firstly, where details of an edition, manuscript or secondary source are mentioned in the course of dcbate; secondly, where one of the parties contests a citation's accuracy or authenticity; thirdly where the identity of the immediate source of a citation sheds light on the development of Bucer's thinking. My work here has been assisted by the annotations and bibliographies in recent cditions of Bucer's Opera latina and Deutsche Schriften (e.g. Pierre Fraenkel's edition of the Florileginm patristicum (c1539)). In many cases, I have been able to supplement these with material found elsewhere. In all cases I have noted the location of citations in Migne's Patrologia graeca and Patrologia latina (or other editions where Migne is deficient).

Chapter Five considers Bucer's early writing on eucharistic sacrifice. 'The chief works considered here are Summary (1523), Kurtzer wabrbaffiger Bericht (1524), De caena dominica (1524), Grund und Ursach (1524), various reports on the Mass written by the Strasbourg Reformers between 1526 and 1529 and Bucer's Apologia Confessionis tetrapolitanae (1531). I have also drawn on Bucer's commentaries on the Synoptic Gospcls (1527) John (1528) and Psalms (1529).

Chapters Six to Ten cover the period between 1534 and 1546. Chapter Six situates Buccr's ideas on the Mass in the context of his aspirations for a general or mational council. The chicf works considered here are his Furbereytung zum Concilio (1534) Bericht auss der beyligen Geschrift (1534) and the ms. Consiliam theologicum (c1540).

Chapter Seven examines a number of irenic accounts of the Mass written by Catholic theologians in the wake of the Diet of Augsburg in 1530. Here particular attention is paid to the work Georg Witzel, Bucer's collocutor at Leipzig and Johannes Gropper, his collocutor at Worms.

Chapter Eight examincs the articles on the Eucharist from the Second Colloquy of Leipzig (1539) and the secret colloquy of Worms (1540). Material which helps explain the content of these articles is drawn from some of the worlss which Bucer published or wrote at around the same time: it particular his Adversus Axiond catholicum (1534); the Romans commentary (1536); Consilium theologicum and the Florilegium patristicum (a ms. anthology of patristic citations which Bucer 
began in the late 1530s).

Chapters Nine and Ten examine two works published after the first Colloquy of Regensburg: Constans defensio (1543) and De vera et fulsa caenue dominicae administratione (1546). After 1541, Bucer began to lose hope in the possibility of negotiated reunion. Johannes Gropper, his principal Catholic collocutor was now his opponent. By examining Bucer's literary skirmishes with Gropper and another Catholic moderate, Bartholomaeus Latomus, I hope to identify which parts of the Leipzig and Worms articles represented genuine agreement and which concealed misunderstanding or were ambiguous. 


\section{THE PLACE OF TRADITION IN THE DEBATE ON THE SACRIFICE OF THE MASS}

\subsection{Introduction}

The following lines opened the treatise Quam brevis fuerit missa by the fourtecnth-century theologian Heinrich von Langenstein (d. 1397).

Matthew 26 and Luke 22 demonstrate how short the Mass was, both with respect to its words and its ceremonies when Christ instituted it by celebrating the sacrament of the Eucharist. However, because the Eucharist is the sacrament which is most noble, worthy and rich in the gifts of salvation, and because it is the memorial of the divine passion, so, with the passage of time, and in accordance with an inspired design, many further things have been added to the Mass of Christ, in a way conducive to reverence for the sacrament, to the solemnisation of the consecration, to the impetration of its manifold fruits and to the saving representation of the divine passion, as the Holy Spirit has instructed the apostles and the holy fathers of the primitive church, ${ }^{1}$

Here already the tensions which would open up into a breach between the Reformers and their opponents were evident. On the one hand, the first "Mass" celebrated by Jesus was a ritual of few words and ceremonies. According to Von Langenstein, these still constituted what was essential: the words of institution, the sacramental elements, and the intention of the priest. By these alone was the sacrament "confected." On the other hand, the church had inherited a complex of "accidentals": ceremonies associated with the cclcbration of the Mass. According to the tradiciones palrum, some of these could be omitted only at the risk of sin. Thus Von Langenstein was forced to make a further distinction between what he called "essential" and "accidental" accidentals. The former were prayers and gestures which were used in evcry celebration of the Mass: e.g. the Canon. The latter were those ceremonies which were used in some Masses but not in others: e.g. the Creed, the Gloria and the Sequences sung before the Gospel. ${ }^{2}$ It is not clear whether Von Langenstein regarded this lattcr category of "accidental" accidentals as part of the "inspired design" through which the Holy Spirit had taught the church. More importantly, he does not tell us whether he thought the contemporary church had any competence to modify, replace or remove the accidentals of the Mass, essential or otherwise. Bccausc little in the way of any conflict between these accidentals and

\footnotetext{
${ }^{1}$ Quoted in A. Franz, Die Messe im dentschen Mittelalter: Beiträge zur Gescbicbte der Lilurgie und des religiösen Volkslebents (Darmstadit, 1963), 518.

${ }^{2}$ Ibid., 519.
} 
the "first Mass" had been identified explicitly, little consideration had been given to whether the authority of Scripture or that of Tradition should take precedent in its resolution.

In two tracts published in 1520 - Sermon von dem netuen Testament and $\mathrm{De}$ captivitate Babylonica, Luther launched an attack on the received view of the Mass as a sacrifice. Although Francis Clark argues that such attacks were not unprecedented in the "thcological underworld" of the Middle Ages, Luther's Catholic opponents viewed matters otherwise. In the preface to his De sacrificio missae (1526) Johannes Eck wrote:

No-one is found in the 1490 years following the passion of Christ who has denied that the venerable Eucharist in the sacred office of the Mass is a sacrifice. 'The whole church spread throughout the world has always held this to be the case... as much among the those holding to the true faith as among the heretics and schismatics. ${ }^{4}$

Eck thought that there might be some preccdent for Luther's protest annong an obscure group of North-African Arians who had denied that the Eucharist was offered to Christ, but even these, he said, had not denied its sacrificial nature. ${ }^{5}$ Protest against Luther's other "captivities" of the Sacrament (transubstantiation and communion under one kind) had punctuated the Middle Ages. Councils had responded with formal decrees on these questions. Lateran IV (1215) spoke of the consecration of the eucharistic bread and wine in terms of "transubstantiation." Constance (1415) ruled out the possibility that this transubstantiation might leave the substance of the bread and wine intact." Against the "Wycliffites" and "Hussites," Constance also asserted that communion under one kind had been introduced into the church with good reason - namely the avoidance of "danger and scandal" - and that those who opposed the practice were in error. Should they

\section{${ }^{5} \mathrm{Clarks,} 76-77$.}

${ }^{4}$ Eck, De sacrificio 1.1 (CCath 36:14).

${ }^{5}$ Ibid., 2.1 (CCath 36:79) The reference here is to $1 d$ Monium libri tres 2.2 (PL 65:179) by Fulgentius of Ruspe. These are not to be confused with the Aeriane/Arriani alluded to in CCA 24 (CCath 33:162) and, as we shall see, by Bucer's opponents at Cologne. This group was described in Augustine, De batresibus 53 (PL 42;39f) as followers of a presbyter Aerius "...in Arianorum haeresim lapsus, propria quoque dogmata addidisse [sc. fertur] nonulla, dicens offerri pro dormicntibus non oporterc..." Despite his Arianism this Aerius is not to be confused with eponymous Alexandrian presbyter, Arius. Epiphanius Contra baereses 3.1 (heresy 74) (PG 42:5C3-516) lists several other heresies into which Acrius lapsed. Bucer would refer extensively to this second work when discussing the authoritative status prayer for the dead. See bclow, ch. 10, p. 217.

"DS 581-582 re, the errors of Wydlif; G. Macy, "Ihe Dogma of T'ransubstartiation in the Middle Ages," JEH 45, no. 1 (Jan. 1994):11-41 argues that until this time the pusition known as "consubstatiation" was regarded as a legitimate (though loyically unlikely) interpretation of Lateran IV's transubstantiatis. 
persist in their error they were to be regarded as heretics. Protests about superstitious abuses of the Mass were also common in the same period. ${ }^{8}$ However, while conciliar and papal documents of the mediaeval period referred to the Mass, incidentally, as a sacrifice, a formal definition had never been required.'

Luther, for his part, recognised that the received understanding of the Mass was very widely held in the church of his own day: ut fere nibil sit bodie in ecclesia magis receptius ac magis persuastum. Moreover, it was so, "supported by centuries of practice and accepted by general agreement" that it would not be easy to challenge this consensus..$^{10}$ Yet, he wrote, "my Christ lives, and one is obliged to take greater care in complying with the Word of God than with the understanding of all men and angels." 11

For Luther the Roman Mass came to symbolise all that was fundamentally and diametrically opposed to what he regarded as the "first and chief article" of justification. ${ }^{12}$ As he put it in his reply to Henry VHI's Assertio: "once we havo overcome the Mass, we shall have overcome the papacy entirely." 13 Thus Luther professed his indifference to verba boninum unless his adversaries could show him that the Scriptural foundation of his own case was flawed. ${ }^{14}$ Elsewhere he conceded that the writings of genuinely holy men such as Gregory the Great, Bernard and Bonaventure could be cited in support of the status quo, and yet:

it is safer to count what the saints did without the warrant of Scripture as one of their sins, rather than imitate it as a good example. For you will not greatly offend the saints if you condemn as a sin what they did without certain warrant. ${ }^{15}$

Luther was joined in his antipathy to the received understanding of the eucharistic sacrifice by the other Reformers. In 1524, Zwingli penned a Christliche

${ }^{7}$ DS 626.

${ }^{9}$ Franz, 292-313.

${ }^{9}$ An important conciliar reference is that of Lateran IV (DS 802), "Una vero est fidelium universalis Icclesia... in qua idem ipse sacerdos est sacrificium Iesus Christus, cuius corpus et sanguis in sacrannento altaris sub speciebus panis et vini veraciter continentur." Sec also, DS 794, 822 and 834.

${ }^{15}$ De captivitate (WA 6:512) "Rem arduam ot quam forte sit impossibile convelli aggredior ut quae tanto sacculorum usus firmata omniumque consensu probata sic insederit, ut necesse sit maiorem partem librorum, qui hodie regnant et pene universam Ecclesiarum faciem tolli et mutari penitusque aliud genus ceremoniarum induci seu potius reduci,"

${ }^{11}$ Ibid., 512, "...Sed Christus meus vivit et maiori cura verbum dei oportet observare quam omnium hominum et angelorum intelligentias."

${ }^{12}$ Cf. e.g. Schmalkaldic Articles (WA 50:200), "... die Messe ym Bapstum mus der grosseste und schrecklichste Grewel sein, als die stracks und gewaltiglich, wider diesen Helbartickel strebt."

${ }^{13}$ Contra Henricum (WA 10.2:220), "Triumphata missa puto totum papam triumphare."

${ }^{14}$ De abrogenda (WA 8:432-433), "...furiosis furamus et posthabitis verbis divinis iactemus cum eis verba hominum: Patres, parres, patres, Ecclesia... Concilia... Decreta... .Universitates,..."

${ }^{15}$ Ibid. (WA. 8:449). 
Antwort to the theologians of Bishop Hugo of Constance. The theologians had raised the objection, that if the Mass was not a sacrifice, then Christ must be thought to have deserted the church which had regarded it as a sacrifice for so long. Zwingli replied:

but which one is bis church? It is that which listens his Word. That church has never regarded this sacrament as a sacrifice, as you may in fact discover from the teachers who have becn cited, as well as from the whole congregation of the Christian pcople. This has never regarded the sacrament in such a way that it used it to offer something up..$^{16}$

As we shall sce, Zwingli cited a number of patristic passages earlier in the discussion to make this very point. However, in a work published in the same year in response to Emser's Canonis missae defensio, Zwingli wrote:

Now I warn you not to throw in my way any of those propositions you churn out. Were you to do so, you would ncver make an offering out of the sacrament of the Eucharist - not even if you carticd off with you the testimonies of all the fathers in the entire world. For however many of these you use against me, they cannot weaken the Word of God, except perhaps among those who place more value on the word of human beings.... ${ }^{17}$

Thus, for both sides in the Reformation debate, the question of eucharistic sacrifice was one which threw the relationship between Scripture and Tradition into particularly sharp focus. However before we look at this debate specifically, it would pay us to attempt define Tradition and to consider the way in which its authority was related to that of Scripture on the evc of the Reformation.

\section{2 'The Authority of Tradition on the Eve of the Reformation}

Heiko Oberman has spoken of the Reformation debate about authority as an intensification of two tendencies already apparent in mediaeval theology. He calls these "Tradition l" and "Tradition II." The first, and older of the two tendencies, treated Scripture as a final and sufficient source of authority. Here Tradition was, "the mode of reception of the fides or veritas contained in Holy Scripture." The fathers of the church were the successio doctorum which preserved and passcd on this truth handed down by God. ${ }^{19}$ Oberman contends that before the

\footnotetext{
${ }^{16} \mathrm{CR} 90: 223$.

${ }_{17}$ Zwingli, Adversus Emserum (CR 90:281).

${ }^{18}$ Oberman, The Harvest of Medievd Theology: Gabriel Biel and Late Medieval Nominalism (Cambridge, Mass, 1963), 372.

${ }^{19}$ Ibid., 377.
} 
fourteenth century, scholastic theologians had described their enterprise largely in these terms. ${ }^{20}$ The theologians of Oberman's "Tradition II" appealed to the authority of an, "oral tradition, to a certain undefined cxtent independent, not of the apostles, but of what is recorded in the canonical books." ${ }^{21}$ This parallel tradition was the prescrve of the church's hicrarchy (rather than the more looscly defined successio doctorum) and in certain cases was identified, par excellence, with the teaching authority of the papacy. Here Scripture was not regarded as an entircly sufficient source of authority, even where it was argued that doctrine must be determined maxime or principaliter on the basis of Scripture.

Alister McGrath accepts Oberman's distinction, but argues, "that Scripture, and Scripture alone, was regarded as the materially sufficient source and norm of Christian theology."22 McGrath, for example, argues that the "truths" which the Tradition II theologians derived from Tradition, tended to belong to "subsidiary arcas of Christian thcology" such as the validity of indulgences or the practice of extreme unction. He claims that even the Mariological doctrines, such as the Immaculate Conception, were regaxded as essentially Scriptural. ${ }^{23}$ Here McGrath appears to suggest that the mainstream of mediaeval theology ran tidily into the Reformation appeal to Scripture alone. In fact this was not the case

George Tavard emphasises that in what he calls the "classical synthesis" of early mediaeval theology (akin to Oberman's Tradition I) the sufficiency of Scripture was never sct against the teaching authority of the church in a way that one was thought to take priority over the other. ${ }^{24} \mathrm{He}$ argues that early mediaeval theology tended to extend the notion of "Scripture" or the "sacred page" beyond the Biblical canon to "the overflow of the Word outside Sacred Scripture" in the creeds, in the decrees of the councils and in the writing of those fathers "received" by the church. "Ithus, enumerations of the sources of "catholic truth" such as that of Willian of Octsham (1300-1359) did not suggest any hierarchy in which truths

${ }^{20}$ Ibid., 373-374.

${ }^{21}$ Ibid, 373 .

22 McGrath, The Intellectud Origins of the European Reformation (Oxford, 1987), 141. Schüssler, Der Primät der I Ieiligen Sbrift als theologisches und kanonistisches Problem in Spattmittelalter (Wiesbaden, 1977), 73 .

${ }^{23}$ McGrath, 141.

it Tavard, 2. E.g. Bonaventure wrote on the one hand of the sufficiency of Scriprure, tind on the other of an unwritten apostolic Tradition (including the existence in Rome of a painting of Christ by St Luke) which legitimised the devotional use of holy pictures and statues. See Expositiones in libros Sententiarum 3 d.23 q.1 a.4 ad. 4 (Opera 5:246), "Illud tamen verum est quod doctrina fidei magis vcraciter cst tradita, quam aliqua scientia Philosophica: quia Spiritus sanctus, $8 x$ ipse Christus qui decuerunt fidei veracitatem, $8 x$ sacrac scripturas, in nullo falsum dixenant, nec in aliquo possunt reprehendi"; ibid., 3 d.9 q. 1 a.2 ad, 6 (Opera $5: 101)$. $7 f$.

${ }^{25}$ Tavard, Holy Writ or Holy Church the Crisis of the Protestant Reformation (Tondon, 1959), 
not drawn from sources other Scripture could be categorised (after McGrath) as "subsidiary." Jean Gerson (1363-1429) insisted that Scripture was, "a sufficient and infallible rulc for the guidance of the whole body of the church and its members to the end of the age." 27 Yet he allowed that "catholic truths" could be established by means of post-apostolic revelations whether through prophecies and miracles, or the common testimony of the church or of a General council. ${ }^{2 B}$ Thus Gerson could speak of the "subsidiary" doctrine of the Immaculate Conception, defined at the Council of Bascl in 1415, as "newly revealed or declared." Gerson also considered the earlier existence of a feast of the Virgin's nativity as evidence of the Holy Spirit's work in the church. ${ }^{29}$ Whatever the sufficiency of Scripture meant for these writers, it did not amount to a straightforward identity of Revelation and the contents of canonical Scripture. As Hermann Schüssler observes, late-mediaeval discussion of Scriptural authority and its role in the reform of the church, was always linked with a conviction that the church would persevere in the truth, and that its judgements were guided by the Holy Spirit in such a way that Christ could be said speak in it. ${ }^{30}$

But how was this church was to be identified? Tavard notes that in the thirteenth century, theologians had entertained the possibility (albeit a hypothetical one) that a remnant constituting the "true church" might remain faithful to the Scripture while the church reputatione tantum (i.e. what passed for the church in human opinion) defected from the truth. ${ }^{31}$ It is clear, as well, that commitment to the notion of the church's indefectibility did not mean that any of the organs of authority in the institutional church - be they the papacy, the councils, or the writing of the fathers - were universally regarded as exempt from reform or criticism on the basis of Scripture. ${ }^{32}$ It was widely recognised, for example, that the fathers differed among themselves and had erred. The Decreinm Gratiani excerpted passages from Augustine in which this father admitted to errors and warned against

${ }^{26}$ Schijssler, 82f, "Ockham macht hier keith Aussage über den Gewißheitsgrad der verschiedenen genera von Wahrheiten. Fïr unseren Zusammenhang ist jedoch wichtig, da? cr dic Wahrheiten der zweiten Art (i.e. truths not written in the Scripture, but from the apostlcs per successorum relationem vel scripturas fidelitm) ebenso wie die der crsten unmitcolbar auf die Olicobarung жurïclkführt..."

${ }^{27}$ Gerson, De examinatione doctrinarum 2 (1423) (Ocuvres 9:465), "Scriptur'a nobis tradita est tanquam regula sufficiens et infallibilis pro regimine totius coclcsiastici corporis te membrorum usque in finem saeculi."

${ }^{28}$ Tavard, 32-53; Schïssler, 87.

${ }^{29}$ See e.g: Oberman, Harvest, 390 citing Six sermons inédits de Jcan Gerson, ed. Louis Mourin (Paris: [s.n.], 1946), 421 (not in Gerson's, Oeurres 5 or 7). For the background to this debatc, see ibid. $283 \mathrm{ff}$. See also 'Tavard, 55 for a discussion of similar views in Pierre D'Ailly.

${ }^{\text {to }}$ Schüssler, 294-295.

${ }^{31}$ Tavard, 24-26.

${ }^{32}$ Schitissler, 2ff; 
treating his writing as canonical Scripture..$^{33}$ In one such excerpt (later used by the Reformers against their opponents) Augustine insisted that the authority of the canonical Scripture was to be preferred to the writings of all subsequent bishops. ${ }^{34}$ Citing the same passage, Aquinas argued that the writings of those who expounded the Scripture indicated only the probability of a belief, whereas canonical Scripture taught its necessity. ${ }^{35}$ According to Schüssler, this position was well represented in all the theological tendencies in the later Middle Ages. ${ }^{36}$

In the satne period, however - and often from the same theologians - one linds a tendency to give the authority of the church priority to that of the Scripturc. The Western Schism, and the conflict between conciliarists and canonists accentuated uncertainty as to where ultimate authority in the church was located. Moreover, the teaching authority of the church had to be defended against the disciples of Huss who seemed to pit the sola scriptura principle of Tradition I against the church. ${ }^{37}$ Oberman associates the extreme formulations of "Tradition II" with the canonists who were at this time attempting to secure recognition for an unconditional papal primacy. However he argues that conciliarist theologians such as Gerson and D'Ailly were also representatives of this tendency - even though they placed a great deal more weight on the authority of Scripture than did their opponents among the canonistac. ${ }^{38}$ In a passage which would feature prominently in the patristic arsenal of the Reformers' opponents (Contrat cpistolam Fundamenti 4) Augustine had written, "... indeed I would not have believed the Gospel, unless the authority of the church had prompted (commoveret) me to do so." ${ }^{39}$ Oberman regards it as significant that, in citing the passage, D'Ailly had replaced Augustine's commovere with compellere. Thus what Oberman regards as Augustine's view of the church's "practical" and "instrumental" priority over Scripture would give way to a late-mediaeval belief in its historical and "theoretical priority." In other words, the human authors of Scripture were members of the church before they wrote the books of the Bible, and that it was the church which separated out the canonical and non-canonical books. 'T'he same Spirit which held the church in life and unity provided it with the proper interpretation of Scripture so that, as an instrument of

${ }^{33}$ Decretum Gratiani 1 dist.9 c.3-11 (Fricdberg 1:16-18) For the discussion of these passages in early scholasticism and in the later Middlc agcs, scc Schüssler, 48f; 2741 .

${ }^{34}$ Decretum Gratiani 1 dist.9 c.5 (Friedberg 1:17). Cf. Augustine, Epistola 82.1 (PL 33:277). Cf. also: Luther, Von der neuen Eckiscben Bullen (WA 2:626); Zwingli, Coristiche Antwori (CR 90:201).

${ }_{35}$ Aquinas, ST 1a 1ae q.8 a.2.

${ }^{36}$ Schiissler, 279 ..

${ }^{37}$ Oberman, Harvest, 380ff, 386. 'lavard, 51 argues that even Huss is arguing against the cannonists for the "classical synthesis" of church and Scripture.

${ }^{38}$ Oberman, Harvest, 375f.

${ }^{39}$ PL 42:175. 
the Spirit, the church was infallible in matters of faith ${ }^{45}$ In this way the "church," like Scripture, could be used as a criterion for deciding which opinions of the fathers were to be accepted and which rejected - particularly where they disagreed among themselves. Again, there was no agreement as to where this ecclesiastical authority resided ultimately. Some writers - the canonists in particular - argued that such a decision belonged to the pope. Others were confident that in all necessary matters, it was possible to identify a consensus among the fathers. ${ }^{41}$

\subsubsection{Humanism as a complicating factor}

During the same period, however, a complicating factor arose, bringing the tensions between the institutional church and its authoritative texts into sharper relief. Beyond an interest in the retrieval, editing, publication and study of ancicnt (primarily classical) texts, humanism, "did not exist as a coherent system of doctrinc, or code of values or series of five-year plans... convoked no synods, composed no confessions, despatched no commissars to nudge the deviant towards conformity." Why then, should it have posed any kind of threat to the ecclesiastical status quo?

Many of the texts which the humanists claimed to have "retrieved" had in fact been available, read and studied in the West throughout the Middle Ages. The full texts of some of the fathers - principally Ambrose, Augustine, Jerome and Gregory, but also Latin translations of Origen and John Chrysostom - were widely studied. ${ }^{43}$ Though the Latin Vulgate was the "set" scriptural text in the monastic schools and universities, versions of the Grcek and Hebrew texts of Scripture were also available (though not widely so). ${ }^{44}$

However, the principal form in which patristic material was available to Western theologians was the anthology: e.g. Abelard's Sic et Non (c1122) Peter Lombard's Sentences (c1155) and the Concordia discordantium canonum, (c1140) (better known as the Decretzm Gratiani). ${ }^{45}$ A certain amount of patristic scriptural conmentary was also available through the collection known as the Glossa

${ }^{40}$ Obermat, Harvest, 370, 385-386.

${ }^{4}$ Schüssler, $276 \mathrm{ff}$.

42 Matheson, "Hutmanism and Reform Movements," in Impact of Humanism on Western Europe, ed. A. Goodman \& A. Mackay, (London, 1990), 23-40. Cf. Kristeller, Renaissance Thought and its Sotirces (New York, 1979), 21-313.

${ }^{43}$ Rice, "Ithe Renaissance Idea of Christian Antiquity: Humanist Patristic Scholarship," in Renatissance Humanism: Foundations, Form and Legacy, ed., A. Rabil (Philadelphia, 1988), 17.

"4 Loewe, "The Medieval History of the Latin Vulgate," chap. in, Cambridge History of the Bible, ed. G.W.H. Lampe (Cambridge, 1969) 2:143ff; Bentley, Flumanists and Holy Writ: New Testament Scholarship and the Renatissance (Princeton, 1983), 15.

${ }^{45}$ Bougcrol, "The Church Fathers and the Sentences of Peter Lombard," in Reception of the Church Fathers, ed. Backus, 113-164; J. Worclsmeister, "The Reception of the Church Fathers in Canon Law," ibid., 65ff. 
ordinaria. The Glossa took its final form during the twelfth century. It not only influenced the use of patristic and scriptural texts, but sometimes affected the transmission of the scriptural text itself. ${ }^{16}$

The anthologists (and to a lesser extent, the glossators) arranged texts culled from what were deemed authoritative sources, in accordance with a pre-determined systcm of theological or canonical questions. Authoritative sententiae (i.e. opinions) were marshalled for and against a particular quaestio. Logical analysis was used to determine which sententiae were correct. This arrangement not only removed the texts used from their original context, but encouraged readers to look on the fathers as, "purveyors of logically deducible and definable statements." ${ }^{37}$

Pertinent to the discussion here are the sententiae marshalled in the eucharistic debate between two monks of Corbie: l'aschasius Radabertus (d856) and Ratramnus (d868). The Carolingian renaissance of the ninth century had seen a surge in the copying and distribution of patristic texts in the monasteries of Charlemagne's empire. Paschasius and Ratramnus arranged sententide from these texts under a series of headings related to the nature of Christ's presence in the Eucharist, the proper form for its administration, and the relationship between the Christ's sacrifice and that of the Mass. Both the headings of the debate and the texts marshalled under them informed all subsequent discussion of the Eucharist whether canonical, controversial, or systematic - up to and including the Reformation. Lepin lists twenty-four fundamental texts on the eucharistic sacrifice which would reappear consistently throughout the Middle Ages and Reformation. ${ }^{48}$ A number of these will be considered further in this and subsequent chapters.

The difference between humanist and previous scholastic interest in such "authorities" lay not in any doubt as to their value, but in the way in which the humanists read them. ${ }^{19}$ The drive to return to the linguistic fontes of the classical literary tradition was parallelcd in humanist thcology. In about 1440, the Roman humanist Lorenzo Valla (c1406-1457) produced the compendious Elegantiae linguae latinae: an immensely popular handbook on questions of Latin stylc and usagc. During the same period Valla was also engaged in the production of his Collatio

${ }^{46}$ Matter, "The Church Fathers and the Glossa Ordinaria," in Reception of the Church Fathers in the West, ed., Backus, 83.

${ }^{47}$ Stinger, "Italian Renaissance Learning and the Church Fathers," in Reception of the Charch Fatbers in the West, ed., Backus, 474.

${ }^{48}$ Lepin, L'idée du sacrifice de la messe d'après les théologiens depuis lorigine jusqu'à nos jours (Paris, 1926), 37ff.

49 For the following see Rice, "The Renaissance Idea," 18ff.; Camporeale, "Renaissance Humanism and the Origins of Humanist Theology," in Humanity and Divinity in Renaissance and Reformation, ed. J. W. O'Malley (Leiden, 1993), 108ff, esp. 111-113. 
novi testamenti. ${ }^{50}$ Using the tools of classical philology Valla sought to recover the veritas graeca from the variants of the available Greek manuscripts. Using the same tools Valla produced a commentary or collatio in which he discussed his choices and assessed whether the available versions of the Vulgate had properly translated this Greels text. This relativisation of the Vulgate in favour of the "truth" of the original languages had profound implications for theology informed by Jerome's translation and the variants thereof. It is well known that Valla expressed doubts as to whether a scholastic theology of co-operating grace, or of penance could be sustained on the basis of the Greck text of Scripture. ${ }^{51}$

Humanist critical techniques were also associated with a new kind of historical consciousness. The body of works attributed to Dionysius the Areopagite, had been regarded as a witness to the belief and practice of the primitive church - particularly the primitive Eucharist and the ministry. Nicholas of Cusa had called the traditional attribution into question because he did not find the works of Dionysius mentioned by Ambrose, Augustine or Jerome. Valla, however, was able to find stylistic evidence for Cusa's suspicions and located the origin of the Dionysian corpus in the sixth rather than the first century. ${ }^{52}$ As the task of recovering, editing, and eventually printing the works of the fathers continued, the authenticity of other texts was called into question.

Finally, humanist theology shared its secular counterpart's suspicion of scholasticism. To the fourteenth and fifteenth century Italian oligarchies, the educational programme of the thcological scholae seemed impractical. What their offspring needed was not speculative knowledge, but training in the skills which would prepare them for the political life of the Italian city statcs. The subjects embraced by the new programme were precisely those which seemed to have equipped men like Cicero for engagement in the affairs of the Roman republic: grammar, rhetoric, poetry, history and moral philosophy. The new programme was concerned less with mastery of truth than with persuasion, negotiation, the inner life and the practice of virtue. ${ }^{33}$

To the humanists, scholastic speculation represented the triumph of method over content. Scholastic theology argued for the usefulness of classical philosophy as a tool for exploring the data of scriptural rcvelation. Humanist thcology

${ }^{50}$ Erasmus published, the Adnotaliores (1505) a revised and enlarged edition of the Collatio. J. H. Bentley, Humanists and Holy Writ, 35.

${ }^{51}$ Bentley, Humanists and Holy Writ, 57; 64.

${ }_{52}$ A. M. Rituer, "Dionysius Areopagitica im 15. und 16. Jahrhundert," in Atictoritas Patrum: Contributions on the Receplion of the Church Fathers in the Fifteenth and Sixteenth Century, ed. Grane, 152ff; K. Froelich, "Pseuto-Dionysius and the Ruformation of the Sixteenth Century," in PscudoDionysive, ed. \& transl. C. Luibheid \& P. Rohren (London, 1987), 33-46, esp. 38ff.

${ }^{53}$ Nauert, Humatnism and the Culdure of Renaissance Europe (Cambridge, 1995), 12-13. 
emphasised the gulf between philosophical opinion and divinc revelation. No analogical comparison or point of intersection between the two was possible. Rather the task of the true theologian was to understand Revelation on its own terms: i.e. in the language in which it was presented. ${ }^{54}$

Here patristic theology, like the literature of the Latin "Golden Age," represented a purer state of affairs from which theology had declined. In his programme for theological studies, Ratio verate theologice (1518) Erasmus characterised Scripturc as a fountain flowing into a golden river of patristic theology, and then degenerating into the dirty rivulets of scholasticism. ${ }^{55}$ The difference between the old and the new modes of theologising could be secn in their fruits. The Schools produced a yclping Babel of conflicting opinions. Unlike the fathers, the Scholastics had rashly sought to speak of the Truth before they had learnt the language in which Truth had disclosed Himself. The barbarous quality of their Latin seemed as much evidence of this as the internecine squabbles between "Thomists," "Scotists," and "Ockhamists."

Theologia vera, on the other hand, tended toward harmony because it took Christ, the Logos, as its model. His philosophy amounted in the end to only a few clear words: "Love the Lord your God with all your heart and your neighbour as yourself." In the same place Erasmus cited 1 Timothy 1:5: "the end of the Law is love from a pure beart, a good conscience, and an unfeigned faith." This, Erasmus wrote, was the sighting and lode-star from which every examination of the Scriptures should take its bearing. ${ }^{57}$ 'l'he theologian should, neverthelcss, be aware that Christ had "accommodated" this simple teaching to the diversity of those who heard him in order to draw all conditions of people to a life of holiness. ${ }^{58}$ This variety continued to characterise the teaching of the apostles and their successors, for:

just as singing is rendered most pleasant by the bringing together of diverse voices, so the variety of Christ brings about a fuller song. Thus

${ }^{54}$ Cannporeale, 108ff. Erasmus, Ratio (LB 5:83BC) insisted that he did not condemn scholastic studies as such, but a narrow dependence on them leading theologians, "deque his rebus magno supercilio proncunciare, de quibus Paulus e terio coelo reversus, nots ausus est hiscere."

${ }^{55}$ Ratio (LB 5:82A).

${ }^{56}$ Ibid., 90RC, 133Fif.

${ }^{57}$ Ibid., $135 \mathrm{~B}$.

58 Tbid., 97F-98A, "Accomodiavit sese his, quos ad sese trahere studebat. Ut homines servaret, homo factus est: ut peccatores sanaret, cum peccatoribus familiariter versatus est..." See also ibid. $105 \mathrm{C}-\mathrm{D}$. 
he became all things to all people so that no-one should be unlike him..$^{52}$

Patristic writing exhibited the rhetorical qualities of thenlogia vera. All the Greek fathers and some of the Latins had spoken the original Scriptural languages. Unlike the scholastics they did not seek to force the Scriptures into alien metaphysical categories. They maintained, where necessary, a reverent agnosticism. Like the rhetors of antiquity - and like Christ - they sought to ignite the hearts of those who heard them with the love of God and neighbour. ${ }^{60}$

As we shall see, the Reformation would compel Erasmus to defend the church's Tradition against "innovation" with some vigour. In 1518, howcver, his endorsement of the church's Tradition and its teaching authority was muted. He asserted that one could not dissent on one's own private authority from the publicus Christianus usus and the decisions of those in charge of the church. ${ }^{61} \mathrm{He}$ also conceded that the gradual diminution of faith among Christians had made necessary an increasing number of credal statements. ${ }^{62}$ However the traditional belief of the church (e.g. that Confession is a sacrament) was to be distinguished from disputcs which were not conducive to pietas (e.g. whether Confession is a divine or a human institution). In his Spongia (1523) Erasmus would place the sacrificial character of the Mass in this category: material for scholastic disputes and not something for which someone should be executed. Martyrdom should be for Christ rather than Luther ${ }^{63}$ In the Ratio Erasmus reminded his true theologian that while Christ could not fail, human beings could. In reading the works of past theologians, whether recent or ancient, one must bear in mind the circumstances to which they had been addressed. In the case of the fathers, one could not always be sure that what one was reading had been genuinely written by them. Thus they were always to be read, non cum necessitate credendi, sed cum libertate iudicandi. Everything taught in the church should be judged by the standard of the Gospel (i.e. an sapiat referatque witam Christi) lest the teaching of Christ be twisted into human law. Erasmus

${ }^{5 y}$ Ibid., 92D-E, "sicut e diversis vocibus apte compositis, concentus suavissimus reditur, ita Christi varietas plcniorem efficit concentum. Sic omnibus factus est, ut nusquam tamen sui dissimilis esser," Sec also ibid. 94B.

${ }^{50}$ Ibid., $134 \mathrm{C}$.

${ }^{51}$ Ibid., $90 \mathrm{C}$.

$5^{52}$ Ibid., 92D.

633 Ibid., 10:1663B, ".. an Missa possit aliqua ratione dici sacrificium. Pro his quae solent esse thenata conflictionum Scholasticarum, nec ausim cuiquam vitam eripere si iudex sim, nec velim in capitis discrimen venire." T-Tere the sacrificial character of the Mass was linked with disputed questions such as the divine institution of the papacy, whether cardinals are necessary members of the church, whether Christ instituted confession, whether faith alone confers salyation and whether any work of a human can be called good. Sec also Apologia adversus monachos Fispanos (1523/1529) LB 9:1064D. 
reminds his reader that according to Paul, the spiritual mar judges all things and is judged by no-one (1 Cor 2:15).$^{64}$ It was not long before the Reformers would claim these criteria as their own.

On the eve of the Reformation, then, things stood thus. Scripture was regarded as the sufficient norm for deciding all qucstions of doctrine, but not in a way that its authority was pitted against that of the teaching church, or in a way that saw Revelation as necessarily confincd to its pages. It was regarded as a surer basis for judgement in doctrinal questions than the opinions of the fathers, but it was not automatically concluded from this that there was fundamental disagreement between the Scripture and its interpreters in "unecessary" matters. During the fourteenth and early fifteenth centuries, however, dispute between the canonists, curialists and conciliarists, as well as the challenge to Tradition posed by Wyclif and Huss, had focused attention in an unprecedented way on the question of where ultimate teaching authority in the church resided - whether in the Scriptures, in a general council, or in the office of the papacy. Far more subversive of traditional notions of authority, however, was the impact of humanist scholarship on European intellectual life. The view of history as a decline from "eloquence" to barbarism was transferred from the realm of secular learning to that of theology. Like its secular counterpart, humanist theology was wary of the speculations of the dominant scholasticism, and often derisive of them. In the Scriptural tcxt and in the theological writing of the early church, it claimed to find confirmation that contemporary theology had strayed from its proper task: the conversion of hearts towards the love of God and neighbour. This narrative of historical decline, as well as a now sensitivity to the text and context of the documents with which the humanist theologians worked, encoaraged the humanists to doubt that things in the church had always been as they were now. Read with the new historical and linguistic tools which humanism had made available, the Scriptural and traditional support for certain doctrines and practices began to look less than certain.

${ }^{64}$ Ibid., 5:89E-90F; E.g. re. the fathers ibid., 133B, "... deinde hos cum judicio delectuque leganus: etiansis reverenter legi volo. Homines erant, quaedam ignorabant, in nonnullis hallucinati sunt: dormitarunt alicubi, nonnulla dederunt utcumque vincendis Haereticis, quorum contentionibus tunc fervebant omnia. Practerca vix quisquan est horum, cujus falso titulo non permulta circumferantur: atque adeo, quod cst impudentius, cujus libris non nulta admixta sint alicna." 


\section{THE EARLY DEBATE ON THE SACRIFICE OF THE MASS}

\subsection{Introduction}

I would like to return now to the Reformation debate on the nature of eucharistic sacrifice, and to situate it in the wider debate about the authority of Scripture and Tradition. The period considered here begins in 1520 with Luther's Von dem neuen Testament and ends in 1531 with the publication of Melanchthon's Defence or Apologia of the Augsburg confession. The first part of the chapter outlines the loci communes of the Protestant critique of the Mass. Here I rely chiefly on Luther's writing, though this is supplemented with matcrial from Zwingli, from the Augsburg confession and Melanchthon's Apologia. The second part of the chapter outlines the common-places of the Catholic response. Here we will consider the work of a number of the major Catholic writers on the sacrifice of the Mass during this period: Henry VIII; John Fisher; Hieronymus Emser; Jodocus Clichtove; Joharnes Fabri; Kaspar Schatzgeyer and Johannes Eck. Some material from the Confutation of the Augsbury confession is also included here. 'The Reformers' own appropriation of the fathers and appcal to Tradition is considered in the following chapter.

'The following discussion is confined largely to the debate over the offering of Christ's body and blood ex opere operato to benefit not only communicants but others both living and dead. It will be impossible, however, not to pay at least passing attention to questions of sacramental cfficacy and mediation, the notion of "merit," the veneration of the saints, and prayer for the dead.

\subsection{The Protestant Critique}

\subsubsection{Testamentum et Promissio}

Like his mediaeval precursors, Luther asserted that the whole nature and substance of the Mass lay in the words with which Christ instituted and "confected" the sacrament. ${ }^{1}$ Iuther found no indication in the accounts of the institution of the sacrament that Christ had intended to offer a sacrifice or perform a good work. Rather, in I.uke 22:20 and 1 Corinthians 11:25 he found the cup callcd the "new testament in my blood." In Matthew 26:28 he read that the blood was, "poured out for many for the forgiveness of sins." According to Hebrews 9:16, the activation of a testament required the death of the testator. ${ }^{2}$ Thus in the Supper, Christ had bequeathed to his heirs the promise of the remission of sins and eternal

\footnotetext{
${ }^{1}$ Sermon von dcm neuen Testament (WA 6:355-356); De captivitate (WA 6:512).

${ }^{2}$ Ibid., 513.
} 
life to be ratified irrevocably through his death on the cross. This promise was made prior to any merit or wish of the beneficiaries. Nothing more was required of them than faith which believed Christ's words to be true and did not doubt what a great gift had been bestowed. To confirm this promise Christ had left a sign and memorial, so that as often as it was celebrated, the beneficiaries might give thanks and proclaim his love and generosity towards them. Through the Spirit, given in faith, the recipient of the sacrament was transformed and became a new creature. ${ }^{3}$

In contrast, the Mass under the papacy encouraged the priest and people to believe that they could turn the promise of the sacrament into a work and, "offer Christ himself to God the Father as an all-sufficient victim, and perform a good work which will benefit all those they [i.e. the priests] reconmend to God." ${ }^{4}$ In $D e$ abroganda missa privata (1521) Luther set the received view of eucharistic sacrifice against those scriptural passages - from Hebrews in particular - which spoke of the unique and unrepeatable character of Christ's sacrifice and priestly mediation. These passages would become common-places of Evangelical criticism of the Mass. By a single offering Christ had perfected for all time those who were sanccified (Heb 10:14 \& 1 Pet 3:18). "The Canon of the Mass, in seeking to offer "a pure, holy and spotless victim: the holy bread of eternal life and the cup of everlasting salvation," seemed to be trying to repeat, or at least to supplement, the unrepeatable sacrifice which had put an end to sacrifice for sin (Heb 7:27; 9:25; 10:10). ${ }^{6}$ In a similar way the "priesthood" which claimed to offer the Mass had usurped the common priesthood in which each Christian had immediate access to God the Father through faith in Christ (1 Pet 2:9). In the place of the one Mediator (1 Tim 2:5-7) the church had set up a host of new mediators. ${ }^{\text {? }}$

\subsubsection{The Opus Operatum and its Application to Others}

In defining the sacrament of the Lord's Supper as a "testament and a promise," Luther compared it with, "all the ancient promises of God since the beginning of the world." For this reason, the word "testament" was interchangeable in Scripture with "pact" and "covenant." "lhe ancient promises had all derived their value from the new promise made in Christ. ${ }^{8}$ The rainbow, for examplc, promiscd

\footnotetext{
${ }^{3}$ Ibid., 515 .

"Ibid., 522, "Omnes imaginantur, sese oflerre ipsum Christum den patri tanquam hostiam sufficientissimain et bonum opus facere omnibus quibus proponunt prodesse."

"Luther, De abroganda (W 4 8:415); Cf. Zwingli, Auslegen 18 (CR 89:114f); De canone (CR 89:5836); CA 24.27 (BS 94).

${ }^{6}$ Luther, De abroganda (WA 8:448); Vom Greuel (WA 18:29); Zwingli, De canone (CR 82:584, 592); Auslegen 18 (CR 89:112ff). Cf. Canon missae, Unde et memores.

${ }^{7}$ Luther, De abroganda (WA 8:415, 417); Zwingli, Arslegen 17, 19 (CR 89:103ff; 157ff).

"De captivitate (WA 6:514) "Hoc testamentum Christi praefigurarum est in omnibus promissionibus dei ab initio mundi, immo omnes promissiones antiquae in ista nova futura in
} 
Noah that God would be favourable to him and his descendants. ${ }^{9}$ He distinguished these promises from the "figures of the law" which simply prefigured Christ but in themselves were only "sacraments of works." from the "Old Testament," ratified through the blood of beasts which promised not the forgiveness of sins, renewal in the Spirit and the inheritance of heaven, but the promised land of Canaan. ${ }^{11}$ Under both Testaments, however, there were sacraments proper: divinely instituted promises joined to signs. ${ }^{12}$ It was not, Luther wrote, the sacrament (i.e. the sign) which brought its recipient justification, but the recipient's faith in the promise to which the sign was appended (non sacramentum sed fides sacramenit iuslificat).

Scholastic theology had argucd that the sacraments of the Old Testament (i.e. worship under the Law of Nature and the Mosaic Law) differed from those of the new in that the former morcly significd and promised grace whereas those of New Law signified, contained and "caused" grace. Again, unlike the sacraments of the Old Testament, those of the New conferred grace ex opere operato, i.e. by their very performance and status as divine actions. ${ }^{13}$

Iuther, however, argued that there was no difference between the sacraments of the OId Testament and the New, bccause each came with a promise which demanded faith and could not be fulfilled by any work. 'l'hus it was faith in the promise of God and not circumcision as such which had justified Abraham. ${ }^{\text {IA }}$ The Papists, Luther alleged, placed their faith not in the promise, but in the sign and ritual of the sacrament. 'They claimed that the sacraments of the New Law were elfective in such a way that, "they are of benefit even to those in a state of mortal $\sin$, that neither faith nor grace is required, but that it is enough that one place no obstacle in the way; i.e. that one have no actual intention to sin again." 15

Christo promissione valuerunt, quicquid valterunt, in eaque pependerunt." Cf. Zwingli, Aiks/cgen (CR 89:131), "Testamentum, pactum und foedus wirdt in der geschrifft offt für ein andren grebrucht..."

${ }^{9}$ De captivitate (WA 6:514).

${ }^{10}$ Ibid., $532,515$.

${ }^{11}$ Ibid., 515.

${ }^{12}$ Ibid., 532, 572.

${ }^{13}$ Sce Altenstaig, Lexicon, 287b.

${ }^{14}$ De captivitate (WA 6:532).

${ }^{15}$ Ibid., "...impulsi sunt tantum tribuere sacramentis novae legis, ut prodesse ea statucrent etiam is, qui in peccatis mortalibus sunt, nec requiri fidem aut gratiam, sed sufficere nor posuisse obicem, hoc est, actuale propositum denuo peccandi." See, however, Altenstaig, Lexicon, 286b, where this is described as the opinion of "some" and attributed to Scotus, Quatesiones in libros sententiarum 4 d.1 q.4 (Opera 16:221-223). Altenstaig (op. cit.) notes that Scotus had in mind Baptism, Confirmation and Extreme Unction where the sacramanncnt might confer grace on one who did not bave perfect reason. i.e. a child or an unconcious person in whorn there could not be a genuine movenent of the soul from original or mortal sin and toward God. Altenstaig also refers to the opinion of "others": "...signa vel sacramenta conferre gratian ex opere operante [sic] \& per modum meriti, quando, sicilicet sacamentum foris exhibitum non sufficit ad gratiae collationem, 
The debate ovcr the difference between the Old and New Testaments formed an appendix to the Reformation debate over the nature of justification. Just as Luther's Catholic opponents feared that justification sola fide would lead to the elimination of good works from the scheme of justification, so they feared that Luther's insistence on the fides sacramenti would make the sacraments of the New Testament mere signs. Even in De captivitate Babylonica, however, Luther argued that while the sacraments under both Testaments promised grace they were, in both cases, effective signs: where undoubting faith was present, the sacraments, conferred grace "most surely and effectively." 16 This fides sacramenti was not a work of the recipient, but the work of God. Discussing the baptism of infants, Luther claimed that, "the Word of God, when it sounds, has the power to change the ungodly heart which is no less deaf and incapacitated than any baby." Citing Matthew 9:1 he also argued that chrough the prayer of the believing church even a child could be filled with faith, changed, purified and renewed. ${ }^{17}$ Despite his criticism of the Papists' faith in the opus operatum, Luther claimed that Gregory the Great had been right when he said that the Mass of a bad priest was of no less value than that of a good priest. This, he said, was because the Gospel, (and thus the declaration of the divine promise) could be preached even by the ungodly. ${ }^{18}$ Moreover, he admitted a sense in which a sacrament could be called a work and an instrument. In baptism one human being performed a work by immersing another. He performed this work as an "instrument or vicar of God." However, it was truer to say that Christ, seated in heaven, dunks us with his own hands, promising the remission of sins on earth in the voice of a human being emanating from the mouth of his minister. ${ }^{19}$

Much of this material was systematised by Melanchthon in the Augsburg confession (1530) and its "Defence" or Apologia (1531). Against the Sacramentarians and Swiss Reformers, the Confession asserted that the sacraments were no mere signs: i.e. "marks of profession among humans." Rather, the promises "presented and shown" in the sacraments "strengthened and stirred up faith." Such faith was

sed vitra hoc requiritur bonus motus seu deuotio interior suscipientis sacramentum.." See e.g. Alexander of Hales, Glossa in quatuor libros sententiarum Petri Lombardi (Florence, 1957), 75-77 on 4 d.1 q.6. See also Clark, 353-354.

"De captivitate (WA 6:533).

17 Ibid., 538, "Sicut enim verbum dei potens cst, dum sonat, ctiam impii cor inmutare, guod non minus est surdum et incapax, quam ullus parvulus, ita per orationem Ecclesiae offerentis et credentis, cui omnia possibilia sunt, ct parvulus fide infusa mulatur, mundatur et renovatur."

${ }^{18} \mathrm{lbid}$., 526-527; lor Gregory, see Decretum Graliani 2 4.1 c.84 (Eriedberg 1:387); Biel, Expositio 57H (Oberman \& Courtenay 2:398).

${ }^{19}$ De captivitate (WA6:530).

${ }^{20}$ CA 13.1 (BS 68) "... sed magis ut sint signa et testimonia voluntatis Dei erga nos, ad cxcitandam et confirmandam fidem in his, qui utuntur, proposita." 
not an idle quality; the mere knowledge of a story (notitia bistorica) as might be found among the ungodly and in the devil. Rather it was belief in the effects of the story (i.e. remission of sins). ${ }^{21}$ In the Apology Melanchthon wrote that this faith was not within the capacity of human nature, but was from beyond nature: "an act of trust (fiducia) in the will, i.e. wishing for and receiving what is oflered in the promise; namely reconciliation and forgiveness of sins." 22 Thus faith was not a human work, but the work of the Spirit which must result in regeneration and could not exist alongside mortal sin. ${ }^{23}$ To this extent, what the Reformers called "faitl" resembled what their opponents might call gratia gratum faciens, (i.e, the infused habit of divine love conferred and strengthened by the sacraments). ${ }^{24}$ Thus, Melanchthon argued, the doctrine of justification by faith did not exclude the sacraments. ${ }^{25}$

In its section on the Mass, Melanchthon's Apology also contained an important discussion of the nature of sacrifice. Here he made what he considered a crucial distinctions between: (a) a sacrament and a sacrifice; and (b) a sacrifice of propitiation and a sacrifice of praise and thanksgiving. A sacrament was a ceremony or work in which God presents (exbibet) something to us (i.e. the promise annexed to the sign). A sacrifice was a ceremony or work which we render to God in order to honour him. There were two kinds of sacrifice. A "propitiatory" sacrifice was a worls which made satisfaction for punishment (poena) and guilt (culpa) placated the anger of God, and might also merit the remission of sins for others (i.e. it could be "applied" to them). A sacrifice of thanksgiving (sacrificium eucbaristikon) did not merit forgiveness of sins or placate God but was performed by the reconciled on account of the reconciliation and other benefits they had received. 'Thus Christ's was the only truly propitiatory sacrifice. The sacrifices of the Levitical or Old Law were called "propitiatory" only because they signified this future atonement. With the coming of the Gospel, the figurative sacrifices of the Old Law ceased. Now only

${ }^{21}$ CA 20.23 (BS 79).

${ }^{22}$ ACA 4.304 (183) (BS 219) "Ita fides est non tantum noricia in intellectu, sed etiam fiducia in voluntate, hoc est, velle, ex accipere hoc quod in promissione offertur, videlicet, reconcilationem, et remissionem peccatorum..." Cf. ibid., (BS 170-171), "Sentit [i.e. Paulus] enim promissionem non posse accipi, nisi fide. Quare inter se correlatiue comparat et connectit promissionem ex fidem... Quoties igitur fit mentio misericordiae, sciendum est, quod fides ibi requiratur, quae promissionem misericordiae accipit. Et rursus quoties nos de fide loquimur, intelligi volumus obiectum, scilicet misericordiam promissam."

${ }^{23}$ MCA 4.64 (BS 173) "Cum autem de vali fide loquamur, quae non est otiosa cogitatio, sed quae a morte liberat, et nouam vitam in cordibus parit, et est opus spiritus sancti, non stat cum peccato mortali, sed tantisper dum adest bonos fructus parit."

${ }^{24} \Lambda \mathrm{CA} 4.116$ (BS 183) "Et quia sola haec fides accipit remissionem peccatorum, ot reddit nos acceptos Deo, et affert spiritum sanctum, rectius vocari gratia gratum faciens poterat, quan effectus sequens, videlicet dilectio."

${ }^{25}$ ACA 4.73 (BS 175). 
"eucharistic" sacrifices remained, and these were praise, the preaching of the Gospel; invocation of the name of Christ; thanksgiving, confession and the afflictions of the saints; "in a word, all the good works of the saints."

Melanchthon correlated these conclusions with a number of Scriptural passages. First, there were the New Testament epistles which referred to the common priesthood and spiritual sacrifices of Christians (Rom 12:1; 1 Pet 2:4; Heb 13:15). John 4:23 offered further evidence that the worship of the New Testament "in spirit and in truth" abrogated the Levitical sacrifices and found its highest form in the righteousness of faith. Melanchthon then turned to the Old Testament. He alluded to the critique of the sacrificial cult in Jeremiah 7:21ff and "the other Prophets" (unspecified). He mentioned the passages in the Psalms (LXX Ps. 4:5; $49: 8-15 ; 50: 16-17 ; 39: 6-7 ; 115: 17-18)$ which referred to the sacrifices of righteoustess, praise, thanksgiving and a broken spirit which are pleasing to God. ${ }^{27}$ It was in this sense, Melanchthon argued, that the Mass could legitimately be called a sacrifice, and in this sense that the fathers had understood the eucharistic sacrifice as well. In the Mass there was a memorial of the death of Christ through proclamation of the Gospel and faith which believes that reconciliation has been won through the death of Christ. From this arose the offerings of thanksgiving, confession and afflictions borne in faith. ${ }^{28}$

A similar distinction between Christ's sacrifice and the sacrifice of Christians is found in Zwingli's Auslegen und Gründe der Schlufreden (1523). By taking up their cross and following Christ, (Luke 9:23f) Christians could be said to "offer" themselves (i.e. to renounce themselves and their possessions, and to bear sufferings for Christ's sake). However, this was not to "offer Christ" but to offer oneself in memory of the sacrifice of Christ accomplished once and for all. ${ }^{29}$

Thus it was not the vocabulary of eucharistic sacrifice which was in itself objectionable to the Reformers. The grounds on which the Mass was found objectionable was expressed in two phrases, already noted in Luther's De captivitate Babylonica, which run like a refrain through Melanchthon's Apologia. They are ex opere operato and sine bono motu utentis. The papists were alleged to hold that by the mere performance of the Mass, remission of guilt (calpa) and satisfaction for the punishment due to sin (poena) could be applied not merely to those who participated in the sacrament, or to even those who were mercly present, but to those whom the priest named in his prayer, whether living or dead. The Mass, in other words, was treated as a propitiatory sacrifice which merited grace for those

\footnotetext{
${ }^{26}$ Ibid. 24.25 (BS 356).

${ }^{27}$ Ibid., 24.33 (BS 359)

${ }^{28}$ Ibid., 24.38 (BS 361).

${ }^{29}$ CR 89:129-130.
} 
who offered it and for others. The papists were also alleged to hold that, as with the other sacraments, the opus of the Mass won grace for others even where they showed "no good movement.". Here, it appeared, was the fountainhead of a multitude of abuses and superstitions.

Again, the theological foundation of these clains appeared to be the Canon of the Mass which referred to the church's "offering" for those not present - even to the dead "marked with the sign of faith" (i.e. those in Purgatory) ${ }^{30}$. The Augsbury confession claimed, as well, to have detected an "opinion" that Christ's passion had made satisfaction for original sin only, and that the Mass had been instituted for the forgiveness of "daily" or actual sin committed after baptism. ${ }^{31}$ This (or so Melanchthon believed) provided the theological basis for the "nultiplication of Masses"32 At the side altars of the principal churches and in private chantries, the Reformers saw Masses recited daily not only for the remission of sins, but for protection against adversities such as plague, floods and bad harvests. The Canon also referred to the church's "offering" in memory of the saints in order that the church militant might benefit from their "merit" and intercession. ${ }^{3.3}$ Here, again, the opera of the saints seemed intended to supplement or, still worse, supplant the sufficient work of Christ. Finally, because the Mass could be offered for absent beneficiaries, no-one other than the priest need receive the sacrament: hence the "private Mass." ${ }^{34}$ 'I'hus the sacrament, in which Christ bid the faithful eat and drink, was overthrown and turned into the sacrificial work of the church.

\subsection{The Catholic Response}

Luther had claimed that the more closely the Mass resembled the first

30 See Canon Missae, Te igitur, Memento Domine, and Memento etiam; Luther, De abroganda (WA 8:450-456); Formula missae (WA 12:207); Vom Greuel (WA 18:26-27, 31); Zwingii, De canone (1523) (CR 89:593ff).

${ }^{31}$ For the source of this opinion Ps.-Thomas Aquinas, De venerabili sacramento Eucharistiae 1, (De venerabili sacramento altari nec non de expositione missae ex operibus D. Thomae Aquinatis excerptus (Rome, 1931), 7-8) "...sicut corpus Domini scmel oblatum in cruce pro debito originali, sic offcratur jugiter pro nostris quotidianis delictis in altari, et habeal in hoc Ecclesia munus ad placandum sibi Deum super omnia legis sacrificia pretiosurn et acceptum." See also Clark, 473.

${ }^{32}$ CA 24.21-22 (BS 93). Cf. CCA 24 (CCah 33:163) “... hoe numquam anditum est a catholicis iamque rogati plerique constantissime negant ab eis sic doceri."

${ }^{33}$ Luther, Vom Grenel (WA 18:27); Zwingli, De canone (1523) (CR 89:574ff); Auslegen (CR 89:1631). See Canon missa, Communicantes.

${ }^{34}$ The term was not an invention of the Reformers. It originated in the 10th century as a description of Masses said in private houses or monasteries. See, Vogel, "Une mutation cultuclle inexpliquée: le passage de l'eucharistie conmunautaire à la messe privée," Revue des sciences religienses 54 (1980):240; Jungmann, The Mass of the Roman Rite: its Origins and Development, transl. F. Brunner, 2 v., (New York, 1951) 1:212-233. 
"Mass" of Christ, the better it would be ${ }^{35}$ Implicit here was the assumption that the present Mass did not resemble the first Mass. Consequently, and because of the wider ecclesiological implications, the Catholics were bound to answer Luther with counter-arguments drawn from Tradition. Some, such as the Franciscan Kaspar Schatzgeyer, held that Scripture demonstrated sufficiently that the Mass was a sacrifice. He insisted, as well, that Scripture alone provided a firm, clear and certain foundation for true doctrine. Unlike the fathers of the church, the Holy Spirit could not err., ${ }^{36}$ Thus, in his writing on the Mass, we find only an occasional reference (or, at least, an occasional explicit refexence) to the fathers. Nevertheless, Schatzgeyer argued that even if it could be shown that there was not sufficient support for his case in Scripture, it did not follow that the ratio sacrificii was some Satanic invention. It was clear to Schatzgeyer that the received doctrine of eucharistic sacrifice had lasted well over a nillennium. To suggest otherwise would be to cast doubt on Christ's promise to remain with his church to the end of time (Matt 28:20). ${ }^{37}$

Thus, irrespective of how a Catholic apologist understood the precise relationship between Scripture and Tradition, the sense of Scripture was regarded as identical with the intexpretation inherited by the church from the previous generations. This church was identified with the councils, the fathers, and the succession of bishops in communion with the see of Rome (though not necessarily with the teaching authority of the papacy). ${ }^{38}$ Luther, as Eck remarked during the colloquy of Leipzig in 1519, seemed to assume that the Holy Spirit had hidden the truth from all the saints and the martyrs, "right up to the point at which the reverend father arrived on the scene." ${ }^{39}$

Unlike Schatzgeyer, however, most of the Catholic apologists felt obliged to admit that Scripture was not sufficient when it came to defending the Mass. Common to these apologists was the assertion that the church was prior to Scripture both historically and theoretically. In his Enchiridion (1525) for example, Eck spoke of an evangelium in cordibus; first articulated in the oral teaching of

${ }^{35}$ Sermon von dem nezien Testament (WA 6:355) "Jhe nehcr nu unßcre meße der crstern meß Christi sein, yhe besser sie on zweyfell, und yhe weytter davon, yhe ferlicher." Cf. De captiviate (WA 6:523).

${ }^{36}$ Tractatus de missa (CCath 37:157). However, he admits (ibid.) "non omria instituta apostolica litcris esse mandata, sed viva voce expressa et temporum successu ad pusteros usi et consuctudine derivata."

${ }^{37}$ Replica (CCath 37:53-54).

${ }^{38}$ For a discussion of the various currents in Catholic ecclesiology prior to the Council of Trent, see, Thompson, The Ecclesiology of Ceorg Witzel, 1501-1573: a Study in the Calbolic Reformation (Ph.D. diss., University of Pittsburgh, 1977), $7 \mathrm{ff}$.

${ }^{39}$ WA 59:470, 1174-1181, "Et mirum esset, si illam veritatem deus tot sanctis ct martyribus occultasset usque ad adventum reverendi patris." 
Christ, and then in the oral preaching of the apostles. Scripture flowed from this "Gospel in the heart;" but so did the Tradition of the church. ${ }^{10}$ As the prior recipient of this Gospel, the church alone was able and entitled to interpret Scripture.

Moreover, the church was entitled to introduce doctrines, rites and ceremonies which, though they must not deviate from Scripture, had no express warrant in it. The Decretum Gratiani preserved the sententia of Augustine (from Epistola 54 to Januarius) who noted that at the end of the instructions on the the Lord's Suppper in 1 Corinthians 11, Paul had promised to arrange "other" (unspecified) matters when he arrived. ${ }^{41}$ Although Augustine used this passage to justify fasting before communion, its specifically etcharistic context meant that it also featured prominently in Catholic defence of other "universal" aspects of eucharistic doctrine and practice which had no explicit Scriptural warrant. ${ }^{42}$ The passage featured in Eck's Enchiridion with a number of ochers which referred to the Spirit's guidance of the church and to the oral traditions handed on by the apostles. ${ }^{43}$ In relation to the Eucharist specifically, Eck concluded that:

... it was not the custom of the apostles at the beginning to hand on the sacred mysteries of our faith in writing. Because Christ had not written his new testament in words, as had Moses the law, but on the hearts of the faithful (as we sec in the prophecy of Jeremiah [31:33]) the apostles handed on the mysteries on from hand to hand (as we have it on the authority of John Damascene's book against iconoclasm). ${ }^{4}$

In his Enchiridion Eck took what Polman describes as the Catholics' "characteristic pleasure" in arguing that, for the sake of consistency, the Reformers should not accept the perpetual virginity of Mary, the bomoousion, or the "Lord's day," since none had explicit scriptural warrant. Eck argued that it was clear from references to Baptism in the name of Jesus in Acts, that the apostolic church had

${ }^{10}$ Enchridion 1, 4 (CCath 34:26f, 29f., $76 \mathrm{ff}$ ).

${ }^{41}$ Decretum Gratiani 3 de consecr. dist.2, c.54 (Friedberg 1:1334); Cf. Augustine, Fpistnla 54.8 "ad Ianuarium" (PL 33:203).

${ }^{42}$ See e.g. Emser, Missde assertio (1525) (CCath 28:8); Schatzgeyer, Tractatus de missa (CCath 37:155); Eck, De sacrificio 2.2 (CCath 36:83); Clichthove, Proptunaculum, 7b. See also CR 88:550f where this passage and John 16:12 are raised in the debate on the Mass at the first Disputation of Zurich in 1523.

${ }^{43}$ Enchiridion 4 (CCath 34:78). See John 16:12-13; 2 Thess 2:14; 2 John 1:12. See, however, Encbiridion 13 (Ccath 34:154), where he insists that in the realm of human institutions, "nithil addendum est Scripturae, quod corrumpat aut depravet ipsan... constitutiones ecclesiae, etsi non sunt in Scriptul'a in propria formot, tamen emanant ex ea." $94: 1135)$.

${ }^{44}$ Eck, De sacrificio 2.1 (CCath 36:81); Cf. John Damascene, De fide orthodoxa 4.12 (PG 
seen fit to modify even the trinitarian baptismal formula ordained by Jesus. ${ }^{45}$ Since in each case the church drew its authority from the Gospel inscribed in the heart by the Spirit, it was possible to speak of the church, its councils and, indeed, the fathers, as "inspired."

However, if one was to argue that the eucharistic status quo represented the work of the Spirit, this had to be supported by a demonstration that the satus quo was the same as the sacrament instituted in the Supper and observed in the Apostolic church. ${ }^{47}$ Not even the earliest opponents of Luther claimed that the Last Supper was like the present Mass with respect to all its rites and ceremonies. They sought, nevertheless, to demonstrate that with respect to its "substance," the present Mass was the same offering as that inaugurated at the Last Supper and offered on the cross.

\subsubsection{Sacrificium.}

The Scriptural foundation of the Catholic case was the contention that in the institution of the Supper, Christ had inaugurated the sacrifice of the New Testament. Schatzgeyer put it in the following way:

the blessed Saviour handed his body and blood to the church to be offered through his ministers to God the Father in memory of his offering made on the cross and as the everlasting renewal of the effects and fruits acquired through his blessed passion and death on the altar of the cross. ${ }^{48}$

The Catholic apologists rejected the claim that the Supper was a testament at least in the terms asserted by Luther. ${ }^{49}$ Henry VII argued that if it were denied that Christ had offered in the Last Supper, it followed that he could not have made a testament either. Neither could be brought to completion except through Christ's death. In both cases Christ had inaugurated in the Supper what was to be consummated on the cross and commemorated, celebrated and represented in the Supper..$^{50}$ The writers of the Confutation of the Augsburg confession (1530) found

4. CCath 34:29f., 76-77; Polman, 329. Re. the baptismal formula see, Matt 19:20; Acts 2:38; $8: 12 \& \mathrm{c}$.

${ }^{45}$ See e.g. CCath 34:42 "Fatemur cos qui in concilio conveniunt esse homines. At in concilio generali legittimo [sic] reguntur ductore Spiritu suncto qui eos falli non sinit. Nanz et Paulus, et Ionnes, Esrias et David fuerunt homines... Scriptores... canonici infallibiliter scripserunt, qui fuertuat homines. Sic patres in conciliis." See also Iserloh, Die Eucharistie 85, n.93.

${ }^{47}$ Although some Carholic apologists appear to have countenanced the idea that Revelation had not ceased with the apostolic church (Tavard, 167-169) I have not found any attempt to apply such a notion to the Mass.

${ }^{4}$ Replica (CCath 37:45).

${ }^{49}$ See e.g. Eck, De sacrificio 3.4 (CCath 36:148f); Schatzgeyer, Replica (CCach 37:74f).

5s Assertio 7.2 (CCarh 43:152). 
immediate evidence for the sacrificial nature of the Supper in Christ's instruction to, "do this." Old Testament passages such as Leviticus 23:19 facietis bircum pro peccatis) suggested to them that boc facite had a specifically sacrificial context. ${ }^{51}$ This was not an argument which featured prominently elsewhere in earlier Catholic apologetic. ${ }^{52}$ Howcver, Fisher, Eck and Schatzgeyer were content to argue that the facite of the institution implied more than accipite, sumite. ${ }^{53}$

More conclusive for these writers were the alleged typological correspondences between the Last Supper' and the sacrifices of the Old 'lestament. What is not consistently apparent in these discussions of the Scriptural material is that behind these typological proofs stood a tradition of exegesis with roots in the patristic church and mediated through the work of the mediaeval glossators, commentators and systematic theologians.

Genesis 14:18 referred to bread and wine "offered" by Melchizedek priest of Salem. According to Hebrews 7, Christ had put an end to the Levitical priesthood and had been made eternal high priest according to the order of Melchizedek (cf. Ps 109:4 (LXX)). On the cross Christ had not offered bread and wine, but his body and blood. In the Supper, however, he had instituted a sacrifice under the forms of bread and wine. Thus he had instituted the Eucharist according to the priesthood of Melchizedek as a sacramental and memorial offering of the sacrifice performed once and for all on the cross. ${ }^{54}$ Fisher and Eck cited a long catena of patristic passages which linked the priesthood of Melchizedek and the priesthood of Christ on the basis that of an offering of bread and wine. Prominent among these sententiae were extracts from Ambrose's De sacramentis 4 and 5 and Cyprian's Epistola $63 .^{55}$ As Eck

${ }^{51}$ CCA 24 (CCath 33:170), "...Christus dises wort 'facite' gepraucht und dasselbig nach hebraischer, griechischer und lateinischer sprache zu vil malen fur opfern verstanden..." This argument does not feature in the Latin version of the CCA.

${ }_{52}$ The only other place in which I have found this argument is Fabri, Sermones doctoris loannis tabri, habiri Pragae apud Bobemos, de sacrosacnto Eucharistiae sacramento. (Freiburg, 1529), $\mathrm{nn} 2 \mathrm{~b}$.

${ }^{53}$ Pisher, Assertionum defensto 6 (Opera 197); Eck, Enchiridion 17 (CCath 34:209), "Non solum dicit 'stumite,' sed 'facite,' hoc est - conitnetis prioribus et sequentibus -: consecrate, offerte, sumite."; Schatzgeyer, Trattatus (CCath 37:225). Cf. Luther, De abroganda (WA 8:437ff).

5. Clichthove, Antilutberus 2.10.4 (73a); Propugnucuim, 15b; Ecli, Enchridion 17 (CCath 34:200); De sacrificio 3.10 (CCath 36:69, 182-189); Emser, Missce assertio (CCath 28:170); Schatzgeyer, Tractatus; Replica; Von bocbwirdigisten Sacrament (CCath 37:51, 173, 498ff.).

ss Clichtove, Antilutherus 2.11.13 (75b); Emser, Missarmm assertio (CCath 28:20 \& passim); Canonis defensio (CCath 28:45 \& passim); Wider der pröbst falschen Grund (CCath 28:136); Eck, De sacrificio 2.2, 2.8, 3.10 (CCath 36:86, 100-111, 184f); Fabri, Mallets 4:49a; Fisher, Assertionium defensio 6 (Opera 198-199); Sacri sacerdotii defensio 10 (Opera 1263-1267). See Arnobius, In Psalmos (PL 53:496); Cyprian, Epistala 63 (PL. 4:387) (Parts of this letter quoted in Decretum Gratiani 3 de consecr. dist.2, c.2 \& 3 (Friedberg 1:1315f)); Jerome, Epistola 73 (PL 22:676-678) is non-committal but offers the following as a reason for the rypology in Hebrews: "...neque carnis et sanguinis victimas immolaverit... sed pane et vino, simplici puroque sacrificio Christi dedicaverit sacramentum"; Ambrose, De sacramentis 4.3, 5.1 (PL 16:457-458, 465); Augustine, De doctrina christiand 4.21 (PL 34:111) which is mercly a quotation from Cyprian, op. cit. Fisher has in 
and Fishcr noted, Cyprian's letter also served the Catholic case by suggesting that Christ had instituted an offering in the Supper, that he had instructed the priesthood of the church to do likewise in his memory, and that the sacrifice which the church offered was the passion of the Lord. ${ }^{36}$

The sacrifice of Melchizedek belonged to the "Law of Nature" (i.e. the Law which preceded the Law of Moses). A number of the sacrifices of the Mosaic Law were also held to prefigure the Eucharist with particular clarity. One was the paschal lamb of Exodus 12. The Catholics noted the specifically Paschal context of the Last Supper in Luke 22:1\&7, Matthew 26:1, John 13:1, as well as other New Testament references to Christ as the Lamb and Paschal Lamb (e.g. John 1:29; 1 Cor 5:7). In the Last Supper, they claimed, Christ first offered himself figuratively under the form of the paschal lamb. By observing this, the first sacrifice of the Law, he put an end to its figurative sacrifices and priesthood. He then instituted the new sacrifice and priesthood of the Gospel by offering himself again, now sacramentally, under the forms of bread and wine. Like the paschal lamb, the Eucharist was both sacrificed and eaten. ${ }^{57}$ The Confutation of the Augsburg confession also argued that the Mass, like the paschal lamb, was simultaneously a sacrifice and memorial. ${ }^{58}$

Another sacrificial type upon which Eck, in particular, dwelt was the inge sacrificinm: i.e. the twice-daily sacrifice of a Lamb described in Exodus 29:38ff, Numbers 28:3ff, and Daniel 12:9-12. Eck and the Confulation of the Augsburg confession claimed that the reference to the abolition of the perpetual sacrifice in Daniel 12 referred not to the Romans' destruction of the Temple, but to the abolition of the Mass and canonical hours in the Protestant territorics. ${ }^{39}$

As important as the sacrificial types of the Eucharist were the prophecies which spoke of an end to the sacrifices of the Law, and their replacement with a sacrifice of praise, thanksgiving and righteousness. The critique of the sacrificial system in the Psalms (e.g. Ps 49:8-15,23; 51:16-17 (LXX)) and Prophets (e.g. Isa

addition: Chrysostom, "hunc locum enarrans" (though there is nothing on the Eucharistic connection in his commentarics on Gen 14:18, Ps. 110 or Heb 7 (PG 53:327-328; 55:266; 63:101108)); John Daxascene, De fide orthodoxa "1" [i.e. 4.13] (PG 94:1149). Strangely none quotes Jerome, Commentarii in Mattbeum 4 ad. c. 26 (PL 26:202-203) via Decretum Gratiani 3 de consecr. dist.2 c.88 (Friedberg 1:1350).

${ }^{56}$ Eck, De sacrificio 2.4 (CCath 36:98); Enchiridion 17 (CCath 34:201); Fisher, Assertionts confutatio 15 (Opera 469).

${ }^{57}$ Clichthove, Antilutberus 2.10.5 (82n); Eck, De sacrificio 1.9 (CCath 36:53-57, 59, n. 21); Emser, Missae assertio (CCath 28:17); Fisher, Assertionum defensio 6 (Opera 197-198, 202); Schatzgeyer, Replica; Tratctatus de Missa; Von bocbwirdigisten Sacrament (CCath 37:62, 173, 367, 507).

${ }^{5 B}$ CCA 24 (CCath 33:171).

${ }^{9}$ Clichuve, Antilutbcrus 2.10.5 (73a), 2.11 .12 (75a); Propugnaculum, 15b; Eck, Enchiridion 17 (CCath 31:206); De satcrificio 1.5 (CCath 36:35ff); Emser, Missate assertio (CCath 28:17); CCA 24 (CCath 33:165). Eck, De sacrificio 2.4 (CCath 36:97-98) \& Imser, Canonis defensio (CCath 28:83) also citc the type of the panes propositionum or twelve show-breads of Lev 24:5ff (appealing to Origen, In Leviticum 13.3 (PG 12:546; 547)). 
1:1-14; Amos 5:21-22) was read as a critique of worship under the Mosaic Law and not as a critique of the worship of the contemporary church. ${ }^{60}$

Among the prophetic texts used in Catholic apologetic, Malachi 1:11 featured particularly prominently. As we have already noted, the prophecy referred to a single sacrifice offered "in every place" to the glory of God's name. The apologists argued that Christ had offered his sacrifice in one place (i.e. on Calvary) and yet, because Malachi spoke of a "pure offering," the prophecy must refer to the offering of Christ's body and blood in the Mass, not in a bloody manner as on Calvary, but sacramentally in memorial of the one perfect sacrifice. ${ }^{61}$ Eck argued that the Hebrew for "pure offering," minchab, described the cereal offering in Leviticus 6:7-16. Thus, the prophet had referred not just to a general offering of praise, but to an offering of unleavened bread: i.e. the Eucharist. ${ }^{62}$ The Confutation of the Augsburg confession stated that the Catholic reading of Malachi 1:11 had the authority of Augustine's Adversus Indaeos 9.12 and alii catbolici, but did not offer any further citations. ${ }^{63}$ In the same vein, Eck quoted from a Latin translation of a passage in Irenaeus, Adversits baereses 4. Discussing the institution of the Sacrament, Irenaeus said that Christ, "taught the new offering of the New Testament, which the church, having received it from the apostles, offers throughout the whole world." This passage was cited (with acknowledgement to Johannes Fabri) in Eck's De sacrificio missae and his Enchiridion. ${ }^{64}$

Eck also drew attention to Malachi 3:4, (purgabit filios Levi...). This, he claimed, was also to be read as a prophecy of the priesthood and sacrifices of the church under the Gospel. ${ }^{65}$ In this respect Hebrews 13:10 (babemus altare...) and Hebrews 5:1-3 were taken to refer to the external priesthood, altar and offering of sacrifices which remained in the church under the Gospel. Here, in other words, Hebrews was read as commending the offering of Eucharist for others. ${ }^{\text {s6 }}$ One notes here the tendency of Catholic apologetic to assume that much of the sacrificial

${ }^{\omega}$ Clichtove, Antilutherus 2.11.12 (75a); Eck, De sacrificio missee 1.11 (CCath 36:66ff).

${ }^{31}$ Clichtove, Antilutberus 2.10.6 (73b); Eck, De sucrificio misste 1.2 (CCath 36:19ff); Enchiridion 17 (CCath 34:199); Emser, Missde assertio (CCath 28:17); Schatzgeyer, Scrutinium 6 (CCath 5:88); Replicu (CCath 37:47).

${ }^{52}$ Eck, De sacrificio missue 1.2 (CCath 36:22).

${ }^{5}$ CCA 24 (CCath 33:163). See PL 42:60-62. Tor alii catbolici, see below. p. 58.

${ }^{54}$ Irenaeus, Adversus buereses 4.17.5 (PG 7.1:1023) "...novam docuit oblationem, quatn ecclesia, ab apostolis accipiens, in universo mundo offert Deo."; Eck, De sacrificio 2.3 (CCath 36:91); Enchiridion 17 (CCath 34:201) See Fabri, Mallens 4.2 (48b). Fabri (ibid.) notes indebtedness to Erasmus. This suggests that he had access to material which Erasmus was preparing for the first printcd edition of Irenacus's works: Opus ertditissimum Divi. Irendei episcopi Lugdmensis in quinque libros digesizm... (Bascl: Froben, 1526). The ms. in quescion is discussed in Irénée de Lyon Contre les bérésies, cd. Rousseat, 4v. in 8 (Paris, 1965) 4.2:34-35.

${ }^{65}$ Fck, Fnchiridion 17 (CCath 34:199-200) "Ecce Salvator purificavit sacerdotes evangelicos, ut. offerat sacrificia, non in sanguinc, scd 'in iusticia."; De sacrificio 1.3 (CCath 36:25ff).

${ }^{65}$ Eck, De satrificio 1.13 (CCath 36:72, 74); Emser, Missae assertio (CCath 28:18). 
language of the New Testament referred to the external ministry and worship of the church. For example, 11 defence of Mass-stipends the Confutators cited 1 Corinthians 9:13 (... qui in sacrario operantur, quae de sacrario sum, edunt...). ${ }^{67}$ Elsewhere they cited Acts 13:1-3 translating the Greek lcitourgounton as sacrificarent. In other words, the prophets and teachers at Antioch had offered Mass and fasted before setting Barnabas apart for his special task. ${ }^{6}$

Here Augustine's De civitate Dei had a profound influence on the Catholic argument. Citing De civitate Dei 18.51 Eck argued that external sacrifices existed in the church under the Old Testament, beginning with Abel, and would continue under the New 'Testament until the death of the last of the righteous. In both cases there was one and the same spiritual priest: Christ. Under the Old Testament the external sacrifices prefigured Christ's passion, but they also signified the sinner's penitence, death to sin and desire to be fruitful in goodness. In the "time of the Gospel" the priest and victim offered were Christ and this sacrifice of the New Law availed for ever. I Iowever, just as there had been an external cultus and priesthood in the church of the Old 'Testament so must there be under the Ncw. Thus Christ's one sacrifice was offered daily by the ministerial priesthood acting in persona ecclesiae. ${ }^{6}$ De civitate Dei 10.20 , was cited by the Catholic apologists with particular frequency. Augustine described Christ as priest, offerer and offering, and affirmed that, "he wished the sacrifice to be the daily sacrament of this, since he is the head of the body, and the body belongs to him as head, with the consequence that she [i.c. the church] is as much accustomed to be offered through him as he is through her."

Eck and Schatzgeyer recognized that these Augustinian passages referred to the offering of the whole church rather than that of the minsterial priesthood exclusively. They acknowledged that the laity exercised a universal priesthood and that the ministerial priesthood acted on their behalf. Schatzgeyer, for example, conceded that in the Mass the laity did exercise a spiritual priesthood and offer spiritual sacrifices when with devout heart they "set" (sistere) Christ before the Father, and indeed "offered Christ" through moditation upon his passion and recollection of it. However, this was to be distinguished from the solemn external

${ }^{67}$ CCA 24 (CCath 33:161).

${ }^{6} \mathrm{CCN} 21$ (CCath 33:166). Used in 1522 by the theologians of the Bishop of Constance. See text in CR 90:208, n. 1.

69 PT, 41:614; Eck, De sacrificio 3.10 (CCath 36:179P).

70 PI, 41:298, "Per hoc sacerdos est, ipse offerens, ipse et oblatio. Cuius rei sacramentum quottidianum voluit: esse sacrificium, cum ipsins corporis ipse sit caput, et ipsius capitis ipsa sit corpus, tam ipsa per ipsunz, quam ipse per ipsam suetus offerri." Quoted in Clichtove, Antilutherus 2.11.10; Eck, De sacrificio 2.7 (CCath 36:108); Enchiridion 17 (CCath 34:202); Emser, Missae alssertio (CCath 28:19); Fishcr, Assertionis confutatio 15 (Opera 470). 
representation performed by the minister of the Church in the same way as the priests of the Law of Nature and the Mosaic Law (e.g. Abel and Aaron). ${ }^{1}$

\subsubsection{Sacramentum Sacrificii}

While the boc facite of the institution accounts was read as an instruction to offer a sacrifice, the relationship between the church's offering and Christ's sacrifice on Calvary had to be explained in the light of the passages in Hebrews which emphasised the unique and unrepeatable nature of Christ's sacrifice. 'The problem posed by the una oblatio of Hebrews 10:14 was not a fresh discovery of the Reformation. 'The passage was considered by Lombard in the Sentences. As a solution Lombard proposed that, "what is offered and consecrated is called 'sacrifice' and 'oblations' because it is the nemorial and representation of the true sacrifice and holy immolation made on the cross." 72 One of the authorities he offered in support of this was "Ambrose" (in fact John Chrysostom, Itomilia 17 in Hebraeos). We shall return to this passage below. ${ }^{73}$

$\Lambda$ common word used to explain how Christ's sacrifice was "offered" in the eucharistic memorial was repraesentatio. Lombard elucidated with a quotation from Augustine, In Psalmum 22.2 (LXX):

We have it for certain that "Christ, having risen from the dead dies now no more 8c..." [Rom 6:9] However, lest we forget what was done once, it takes place every year in our memorial. Surely Christ is slain as often as the Pasch is celebrated, and yet the annual commemoration represents [repraesentat] what was done in the past and this it causes us to be moved as much as if we saw the Lord on the cross. ${ }^{74}$

Odo Casel has argued that there was a shifi in the meaning of representatio

${ }^{71}$ Ecli, De sacrificio 1.11 (CCath 36:68); Schatzgeyer, Traclatus (CCath 37:217).

72 Lombard, Sententius 4 d.12 a.7 (PL 192:866) "Post hoc querit si quad geril sacerdos proprie dicatur sacrificium vel immolatio et si christus quotidie immoletur vel semel tantum immolatus sit. $\Lambda$ d hoc breviter dici potest illud quod offertur et consecratur a sacerdote vocari sacrificium et oblationes quia memoria est et representatio veri sacrificii et sanctae immolationis factae in ara crucis. Et semel christus mortus in cruce est, ibique immolatus est in semetipso, quotidie autem immolatur in sacramento quia in sacramento recordatio sit illius quod factum est semel."

${ }^{73}$ Chrysostom, Homilia 17 in Helmaeos (PG 63:249-250) (see Lepin, 42-44 and below, p. 63); The orhers are Augustine, In Psalmum "20" [22.2 (LXX)] (PL 36:170-171); "Augustinus in Sententiis Prosperi," i.e. Lanfranc, De corpore et sanguine domini 15 (IL 150:425) (see Lepin, 50-52, 786f). Sce also Decretum Gratiani 3 de consecr. dist. 2 c.51-53, 71-72 (Friedberg 1:1332-1333, 1341$1342)$.

${ }^{74}$ Lombard, Sententide 4 d.12 a.7 (PL 192:866) "Unde Atgustini, "certun habemus quita Cbristus resturgens e mortuis iam non moritur \&c. tamen ne obliviscamur quod semel factum est in memoria nostra, omni anno fit. Sic quotiens pascha celebratur, nunquid totiens Christus occiditur sed tamen anniversaria recordatio representat quod olim factum est et sic nos facit moveri tanq̨uam videanus Dominum in cruce." Cf. PL 36:170-171. 
between its earliest recorded use in a eucharistic context by Tertullian and the aftermath of the debate between Paschasius Radbertus and Ratramnus in the ninth century. ${ }^{75}$ In Latin Christian antiquity, the word had what we might call a "strong sense." Like sacramentum, mysterium, memoria, commemoratio and figura it was used to suggest the real and effective presence of the sacrificial death of Christ and the work of redemption in the eucharistic action as a whole. Following the eucharistic controversies of the ninth and eleventh centuries, the sacramental elements became the focus of speculation regarding the reality or otherwise of the presence of Christ's body and blood. The bread and wine, rather than the entire action now became the sacramentum of Christ's body and blood. The eucharistic action in its turn became the subject of what Adolph Franz calls the "commemorative-allegorical method" of mediaeval commentaries and sermons on the Mass. ${ }^{76}$ The gestures, words, paraphernalia, and even the structure of the Latin rite were thought to present a symbolic tableau of the passion and death of Christ and often, of the whole of salvation history - to the spiritual gazc of the believer. ${ }^{77}$ Here, Casel argues, the representative function of the eucharistic action, considered in itself, was "weakened." The rite either presented the bcliever with the realities which it symbolised in a purely spiritual and inward manner, or it portrayed them in a way designed to encourage meditation but without any intrinsic effect. ${ }^{78}$

It is noteworthy, for example, that Aquinas addressed the relationship between the sacrifice of the Mass and Christ's sacrifice under the heading of, "the ritual of this sacrament." Here the sacrifice of the Mass was considered alongside other matters such as the suitable time, place, "apparatus" and gestures for the celebration of the sacrament. In a well-known passage, on which Bucer would later draw, Aquinas wrote, "the celebration of this sacrament... is a kind of representative image of the passion of Christ, which is his true immolation," "79 To demonstrate what he meant by "representative image," Aquinas quoted Augustine, De octo quaestionibus Dulcitiv: "images are usually called by the name of the things of which they are images, so that when we look at a picture or a painting on a wall we say, "this is Cicero, that is Sallust." For this reason, Aquinas wrote, one could say that Christ was immolated even in the figures of the Old Testament, for, according to Revelation 13:8 [Vulgate] Christ is the "Lamb slain from the beginning

${ }^{75}$ Casel, "Das Mysteriengedächtnis der Meßliturgie im Lichte der Tradition," Jabrbuch für Liturgiewissenschaft 6 (1926): 135 ff., $2 x$ passim.

${ }^{76}$ Casel, 188.

$\pi$ Franz, 728 \& passim; Jungmann, 1:87ff.

${ }^{73}$ Casel, 194.

${ }^{7}$ ST 3a q. 83 a.1, "Celebratio autem huius sacramenti... imago quaedam est repraesentativa passionis Christi quae est vera eius immolatio."; known to many of the Catholic apologists by way of Biel, Expositio 85F (Oberman \& Courtenay 3:101-102). 
of the world." ${ }^{80}$ Anticipating a theme in Reformation critique of the Mass, Aquinas asked here whether the actions performed in the sacrament wcre fitting, since under the New Testament the ceremonies of the Old Law were no longer to be observed. Although he concluded that the actions were fitting because they were the custom of the Church (which was guided by the Holy Spirit and therefore could not err) he justified this claim by arguing that the words and actions of the Mass "represent" Christ's passion, signify his mystical body and encourage the devout and reverent reception of the sacrament. ${ }^{81}$

Casel, however, argues that Thomas (unlike his predecessor Albert the Great or a majority of the theologians who followed him) managed to integrate the reality of Christ's presence in the sacramental elements with the eucharistic action as a whole. ${ }^{82}$ For Aquinas the Eucharist was also called the "immolation of Christ," "because of the effects of the passion. For this reason it is said in a secret prayer one of the Sundays that, 'as often as the memorial of this victim is celebrated, the work of our redemption is carried out." "'s; Thus, although the sacrifices of the Old Testament and the Eucharist tright be equally "representative" at the level of pure signification, the Eucharist was different because in it, Christ is immolated. ${ }^{84}$ Like the other sacraments, the Eucharist makes present what it signifies: in this case the sacrificial offering of Christ's body and blood. 'Thus, in an carlier article of the Summa Aquinas considered whether the sacrament could benefit others besides communicants. Again, he foresaw the objection raised by the Reformers that other sacraments such as baptism were of benefit only to those who received them, "therefore neither is this sacrament [i.e. the Eucharist] of benefit to others than the recipients." $"$ Aquinas argued, however, that the Eucharist was not only the sacrament of a sacrifice, "but a sacrament and also a sacrifice." 86 For Aquinas,

${ }^{30} \mathrm{ST} 3$ a q. 83 a.1, "...solent imayines earum rerum nominibus appellari quantm imagines sunt; sicut cum intuentes tabulam aut parietem pictum dicinus, Ille Cicero est, et ille Sallustius... [Augustine, De octo Dulcitii quaestionibus 2.3.2 (PL 40:143)] poterat dici Christus immolari etiam in figuris veteris Testamenti. Unde et Apoc. dicitur, Quorum nomina non sunt scripta in libro vitae Agnt qui occiszrs est ab origine ritudiz..."

${ }^{81} \mathrm{ST}^{\prime} 3$ a q. 83 a.5.

\$2. Cascl, $194 \mathrm{ff}$.

${ }^{83} \mathrm{~S} \perp$ " 3a q. 83 a.1, "Alio modo quantum ad effectum passionis. Unde in quadam dominicali oratione secreta dicitur, Quotics buius bostiae commemoratio celebratur, opus nostrae redemptionis exercetis;." Cf. Eck, De sacrificio 1.10 (CCath 36:64), "... id quod in dominicae cuilusdam oratione secreta testatur cum inquit: quotiens buizu bostiae... Attende: non solum 'pingitur' aut 'figurntur,' sed etian exercetur, agitur opus redemptionis nostrae."

${ }^{84}$ ST 3a q. 83 a.1, "Sed quantum ad secundum modum, proprium est huic sacramento quod in ejus celebratione Christus immoletur."

${ }^{85}$ ST 3a q.79 a.7 ad.1, "Videtur quod hoc sacramentum non prosit nisi sumenti... alia sacramenta non prosunt nisi sumentibus, sicut effectum baptismi non suscipit nisi baptizatus. Ergo nec hoc sacramentum prodest aliis nisi sumenki."

${ }_{86}^{8 c}$ Ibid. resp. "Dicendum quod... boc sacramentum non solum cst sacramentum, sed etiam est sacrificium." 
conclusive proof of this found in the words of the Canon which referred to the benefits received by those not present at the Eucharist. Thus, "...for others who do not receive, it is beneficial as a sacrifice because it is offered for their salvation." 87

Casel argues that where the boundary between the strong and weak sense of representation was drawn more sharply than it was by Thomas, mediaeval writers were forced to identify a new sacrificial action which would account for the Canon's references to "offering for" others. ${ }^{88}$ For Aquinas the Eucharist and the Cross were one and the same offering: "the sacrifice which is daily offered in the church, is not different from the sacrifice which Christ himself offered, but is a commemoration of it." "For the likes of Albert the Great, however, the victim of the Eucharist and the Cross were one and the same, possessing the same efficacy, but the manner of the offering was different. ${ }^{90}$ Catholic apologetic during the Reformation inherited this ambiguous tradition according which representation could be both effective ('Thomas) and "mere" representation (Albert).

Thus in De sacrificio missae Eck quoted Aquinas' remarks on the Eucharist as a representative image, and then commented:

but the intemperate heretic interrupts what is being said: "this is what I meant," he cries, "the Mass is the memorial of a sacrifice, not a sacrifice, just as the image of thing is not the thing itself, and a picture of a man is not the man himself..." However we shall quickly knock this heretical quibbling on the head, if he will only hear us out patiently to the end of the argument. ${ }^{91}$

Eck procceded to distinguish between the representative function of the sacrifices of the OId Testament and those of the New. He argued that when Aquinas referred to Christ being, "immolated in the sacrifices of the Old Testament" the representation was only fyurative (i.e. "weak"). The sacrifices of the Law merely prefigured the true sacrifice of Christ. The Eucharist, however was truly and particularly called "sacrifice" bccausc it contained invisible grace beneath the invisible species of the sacrament. ${ }^{92}$

$\mathrm{UP}$ to this point, Eck had simply followed Aquinas, and like Aquinas argued that the Eucharist was effective not only when it was received by the priest and people in communion, but when the Church offered the body and blood of Christ eonum offertur."

87 Thid., "... aliis qui non sumunt prodest per modum sacrificii, in quantum pro salute

${ }^{88}$ Casel, 194.

${ }^{89}$ ST 3a q. 22 a.3 resp.2, "Sacrificiunn autern, quod quotidie in ecclesia offertur, non est aliud a sacrificio, quod Christus ipse obtulit, sed eits commenoratio."

${ }^{90}$ Albert, In 4 libros Sententiarum 4 d.13 q.23; quoled in Cascl, 194.

${ }^{11}$ Eck, De sucrificio 1.10 (CCath 36:62-63).

${ }^{92}$ Ibid., 63. 
to God the Father for others. ${ }^{93}$ For Eck, however, God the Father was every bit as much the indirect object of this effective representation as the faithful: i.e. the Church represented Christ's sacrifice to God the Father. Eck compared this effective representation to presenting a king with not merely a picture or symbol of his triumph, but with the triumph itself. The latter would be far more pleasing to the king than the former. ${ }^{94}$

Eck distinguished this form of representation or memorial from two other kinds of memorial in the church's liturgy. The first was the solemn commemoration of the Passion on Good Friday at which the Church "represented" Christ's sacrifice in gestures, words, rites and vestments, but here any "offering" was mere recordativa. On that day the Eucharist was not celebrated, and only the reserved species was consumed. The second was the "memorial" of the passion of Christ which took place when the priest or a member of the laity received the sacrament 'I'his, again, was recordatio nuda, and not the same as the effective commemoration of Christ's sacrifice in the Mass. ${ }^{95}$

Thus Eck distinguished between a figurative represcntation in the distribution and consumption of the sacrament, and, as we shall see, an effective representation in the prayers immediately following the consecratory formula in the Roman Canon. As Lepin has demonstrated, however, there appears to have been a large measure of agreement among early nediaeval commentators that it was in the communion and the fraction of the host at which the immolation of Christ was renewed mystically or maxime repraesentatur. ${ }^{26}$ This emphasis on the representative character of the fraction and communion was reflected in a number of the patristic sententiae which shaped mediaeval and then Reformation discussion of the Eucharist. ${ }^{97}$ In De sacramentis 4.6 Ambrose had written:

If each time the blood is poured out, it is poured out in remission of sins, I mist always receive it, so that my sins may always be forgiven me. I who always sin must always have sone remedy for them."s

In De Trinitate 3.4 Augustine had written:

${ }^{93}$ Ibid, 1.10 (CCath 36:64), "...ipsum Christum denuo offert [i.e. ecclesia] in odorem suavitatis Deo Patri"

${ }^{94} \mathrm{Ibid}$.

${ }^{95}$ Ibid., 1.10; 3.9 (CCath 36:65; 174ff); Enchiridion 17 (CCath 34:208).

\%" Lepin, 97 fl \& 113 If.

"7) Ibid., 88 fl.

${ }^{28} \mathrm{PL} 16: 446$, "Si quoticscumque effunditur sanguinis, in remissionem peccatorum funditur, debeo illum sempter accipere, ut semper milhi peccata dimittantur. Qui semper pecco, semper debeo habere medicinam." Cited in Lombard, Sententinte 4 d.12 a.8 (PL 192:867). 
we call them the body and blood of Christ, but only in so far as we ritually consume what is taken from the fruits of the earth and consecrated by a mystical prayer, in memory of the Lord's passion for us.."

Biel noted the possibility that the "most distinct" representation of the Lord's passion occurted at communion, on the basis of 1 Corinthians 11:26, (Quotiescunque enim manducabitis panem.. mortem domini annunciabitis donec veniat). He dismissed this, however, in favour of the probabilior sententia doctorum that the most distinct representation of the passion occurred with the separate consecration of the chalice, for boc facite meant conficite. ${ }^{162}$ Nevertheless, the patristic sententiae which suggested that the representation of the Lord's passion occurred at the communion would be used by the Reformers to assert that the sacrificed body and body and blood of Christ were offered to us in the sacrament, but not by us for the remission of sins.

\subsubsection{The Opus Operatum and its Application to Others}

Christ's one sacrifice was thus "offered" daily in memorial, but precisely how was it offered and how were its benefits made available to non-communicants? Here Erwin Iserloh has distinguished between what he calls a "Scotist" and a "Thomist" explanation of the relationship between the cross and the sacrifice of the Mass. ${ }^{101}$ Mediaeval theologians had speculated on whether a priest, asked to offer a Mass for two separate intentions, could fulfil his obligation by saying one Mass for both intentions, or whether he was obliged to say one Mass for each intention. There was general agreement that the priest was obliged to say two separate Masses, but the ways in which the Thomists and the Scotists arrived at the same answer were different.

Scotus observed that the contents of the pyx (i.c. the reserved host) were not regarded as having the same benefit for the church as the offering of the host in the Mass. Therefore some distinction had to be made between the contents of the Eucharist and its offering. ${ }^{102}$ Scotus distinguished between Christ's offering of himself immediate ratione voluntatis on Calvary, and the commemorative,

5L P2:873-874, "Corpus Christi et satguinem dicimus, sed illud tantum quod ex truatibus terrae acceptum et prece mystica consecratum, rite sumimus ad salutem spiritualem in memoriam dominicae passionis pro nobis." Cf. Decretun Gratiani 3 de consecr. dist.2 c.60 (Friedberg 1:1337).

${ }^{100}$ Biel, Expositio $53 \mathrm{X}$ (Oberman \&. Courtenay 2:332m333).

101 For the following discussion, see Iserloh, "Wert," 44-79; W. Werbeck, "Valor er applicatio missae: Wert und Zuwendung der Messe im Anschluß an Johannes Duns Scotus," ZThK 69 (1972):163-184.

${ }_{132}$ Scotus, Quatsitones quadlibetales 20.21 (Opera 26:320); Biel, Expositio 26G (Oberman \& Courtenay 1:245). 
"mediate" offering of his body and blood in the Mass. ${ }^{103}$ The latter, unlike the sacrifice of Christ, was limited in its value. Here Scotus and his expositors, such as Gabriel Biel, distinguished between the value of the gift offered and its offerer. In the Eucharist, the gift offered was the body and blood of Christ. The value of this gift was infinite and it was always acceptable to God the Father. However a sacrifice was said to be acceptable not just because of the value of the gift, but bccausc of the disposition (or "merit") of the offercr. Because of his perfect disposition, Christ's immediate offering was completely acceptable to the Father. ${ }^{104}$ However Christ had also commanded the apostles to offer his body and blood in his memory. 'This mediate opus operutum of the church was always in some measure pleasing and acceptable to God, because the church, as Christ's spouse, would never entirely cease to be holy. However the holiness of the church varied and fluctuated across time. Thus the benefits gathered by the church through the offering of an infinitely valuable gift, varied in accordance with its merit. ${ }^{105}$ In addition to this limitation on the mediate opus operalum, the availability of the fruits of the sacrifice was limited by the faith and devotion with which the celebrant and the church (i.e. the opus operantis) received them. If this were not so, said Biel, "just one Mass would be sufficient for the redemption of all souls from all purgatorial punishments and for the conveyance of all gifts." 105

Iserloh identifies Eck as a representative of the Scotist position. ${ }^{107}$ According to Eck, the priest, acting in persona ecclesiat, presents God the Father with the offering made once by his Son on the cross. ${ }^{10 \Omega}$ In De sacrificio Missae Eck specified when this happens in the Mass:

the offering of the Eucharist comes after the consecration and prior to the communion when the minister, cclcbrating in the person of the Church says: "Wherefore, calling to mind \&c. we your servants offer to your excellent majesty from your own gifts and presents..."10

Here Eck also listed the subsequent prayers of the Canon: Supra quat,

\footnotetext{
${ }^{133}$ Scotus, Quacstiones qnodlibetales 20.22 (Opera 26:321).

${ }^{104}$ Ibid.; Biel, Expositio 26G. (Oberman and Courtcnay 1:244-246).

${ }_{105}$ Scotus, Quaestiones quodlibetales 20.24 (Opera 26:321-322); Biel, Expositio 26H (Oberman and Courtenay 1:245).

${ }^{106}$ Biel, Expositio 27L (Oberman and Courtenay 1:265), "Ex quo certum est quod missa non equivalet passioni et morti Christi quantum ad meritum quia in misse sacrificio Christus non iterum moritur, licet mors eius (unde omne meritum) speciatius in eo commemoretur. Alioquin sicut Christus semel tantum passus est ad totius mundi redemptionem, ita ct una missa sufficeret pro redemptione animarum omnium ab omnibus penis purgatorii, et ad impetrationem totius bon.".

${ }^{107}$ 1serloh, Die Eucharistie, 156ff; "Wert," 55, $77 \mathrm{f}$.

${ }^{109}$ Eck, Enchiridion 17 (CCath 34:205), "Itaque sacerdos in persona ecclesiae praesentat Deo Patri oblationem factan per Filium in ara crucis, et oblatum ipsum."

${ }^{109}$ Eck, De sacrificio 3.9 (CGath 36:174).
} 
Supplices te etc. Thus it was not the sacramental presence of Christ, but the rite in which Christ's body and blood were offered which constituted the sacrifice of the Mass. Because this rite - the sacrificial act of the church - was distinct from that of Calvary, it had in itself a limited efficacy. ${ }^{110}$ Nevertheless, the sacrifices of the cross and of the Mass were identical to the extent that they both contained the same victim: the body and blood of Christ which were made present in the consccration. According to Eck, the church did not offer to God something of its own (as Luther had alleged) but the gift which Christ had left it to offer. Here he quoted from the Unde et memores: "offerimus... de tuis donis ac datis bostiam puram..." Thus, Eck could also say that the offering made in the Mass was not properly the opus of the Church. ${ }^{111}$

According to Iscrloh, variants of this "Scotism" marginalised "Thomism" during the fourteenth and fifteenth centuries. ${ }^{112}$ Nevertheless, during the first decade of the Reformation, we find the "Thomist" position advanced in the works of Schatzgeyer and Cardinal Cajetan (Tomasso de Vio). ${ }^{113}$ For Aquinas the sacrifices of the cross and the Mass were identical not merely because the same victim was offered, but because, quodammodo, the same priest (i.e. Christ) performed the offering. Here the sacrifice of the Mass was identified with the consecration. The priest in both cases was Christ, and the minister of the church consecrated in persona Cbristi. ${ }^{114}$ In the Unde et memores and the following prayers, the church's priest excused himself from presumption, and asked that the sacrifice might be acceptable to God and sought its benefits for himself and for others. ${ }^{115}$ Thus, for Schatzgeyer:

The priests of the New Testament do not succeed Christ, for they do not profess a priesthood other than that of Christ, just as they do not profess another sacrifice. Rather they recognise themselves to be ministers of Christ, renewing his one sacrifice consummated on the cross in the hearts of the faithful through a representation which is

${ }^{110}$ Iserloh, "Wert," 79.

11 Eclk, De sacrificio 3. 5 (CCath 36:155) "Hic plane ecclesia agnoscit esse sacrificia dona Dei, et Luther can calumniatur, ac si ecclesia existimet oblationem esse proprie opus nostrum, quod est meritum nostrum, quo mereamur nobis et aliis."

${ }^{112}$ Iserloh, "Wert," 65. He admits, however, that the distinction between the two positions was not so rigid as to prevent hybrids. For exanple, he finds elements of "Thomism" in Biel's Expositio.

${ }^{113}$ Ibid., 50ff., 71ff.; Die Eucharistie, 158; Introduction to CGath 37:7f. See also Fisher Assertionum defensio 6, 9 (Opera 196-197, 222).

${ }^{114} \mathrm{ST}$ 3a q. 82 a.10, "Hoc sacramentum perficitur in consecratione etucharistiae in qua sacrificium offertur." Ibid., q.83 a.1 resp.3, "Dicendum quod... sacerdos gerit imaginem Christi, in cuius persona et virtute verba pronuntiat ad consecrandum, ut ex dictis palet. El ita quodammodo idem est sacerdos et hostia."

${ }^{115}$ Ibid., q.83 a.4. 
perceived by the senses. Because there are not two sacrifices, there are not two priesthoods. ${ }^{116}$

Again:

that offering, by which the church and her minister offers at the altar, is not fundamentally other than the offering of Christ performed on the cross... it follows that, theologically (though not physically) speaking it is not our work as if it came forth from us... it is not an offering from our goods in the way that we make offering from our goods in other cases... it is no less founded on the promise of Christ and on faith than is communion alone. ${ }^{117}$

Schatzgeyer showed no interest in the relationship between multiple Masses and multiple intentions. This question, however, was taken up by Cajetan on the eve of the Reformation in Opuscula aurea de diversis ac curiosissimis materiis (1511). ${ }^{118}$ Cajetan described the absolute opus operatum of the Mass as Christ immolated: the res ablata made present in the sacrament. Its quantity, sufficiency, merit for satisfaction and impetration were infinite because they belonged to the passion of Christ. However, the opus operatum had no particular efficacy except as thanksgiving and memorial before God the Father. In order to be effective, it had to be applied, and in the application, its efficacy was limited. ${ }^{119}$

How does this differ lrom Scotist position? Firstly, Cajetan insisted that there was no mediate opus operatum by which the priest offered the body and blood of Christ to make limited satisfaction for the beneficiary. Cajetan did, however, interpose the intercession of the offerer (i.e. the payer of the Mass-stipend via the celebrant) between the unlimited sacrifice of Christ and the devotion of the individual beneficiaries. The devotion of such an offerer, he wrote, might correspond to only one year's worth of satisfaction. Hence a year of relief from temporal punishment would be made available to one intended beneficiary, but only half a year each would be made available to two. Hence it was not right to celebrate one Mass for two separate intentions. ${ }^{120}$ Cajetan noted, however, that every Mass was also offered for civil government, the church and all Christians individually. Could these also benefit from a Mass said for a special intention?

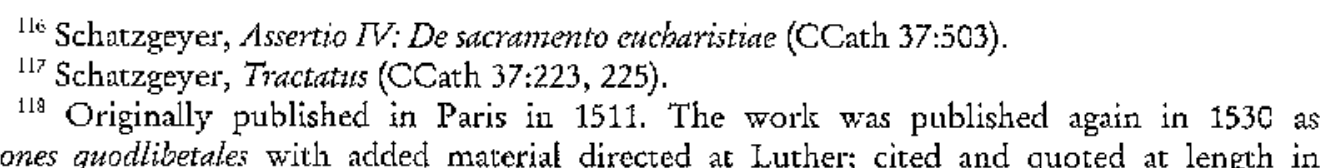
Quaestiones quodlibetales with added material directed at Luther; cited and quoted at length in
Iserloh, "Wert," 71-72; translated in Oberman, Forerumers of the Reformation: the Shape of Late Medieval Thougbt: Illustrated by Key Documents, transl. by P. Nyhus (London: Lutterworch, 1966), 256m263. See also Aquinas, ST 3, Stupl. q.71, a.13-14.

${ }^{119}$ Iserloh, "Wert," 71-72; Oberman, Foremuners, 258.

${ }^{120}$ Iserloh, "Wert," 72; Oberman, Forernmners, 258-261. 
Cajetan concluded that they could, but they would receive only as much satisfaction as their own devotion warranted. They would not, in other words, receive the additional satisfaction transferred from the payer of the stipend to the beneficiary. 'I'hus, through their own devotion, all souls in Purgatory benefited from any Mass, but those which had special Masses said for them would be released from their temporal punishment more quickly as a result of the devotion of others. $^{121}$

Iserloh regards the Scotist understanding of the Mass as the root of the "multiplication of Masses." ${ }^{122}$ Yet, as Oberman points out, Cajetan reaches the same conclusion as the Scotists by a different route. The limited benefits derived frorn the Mass may be a consequence of the limited devotion of individuals rather than the church's mediate opus operatum, but the multiplication of Masses is still thereby vindicated. ${ }^{123}$ As Cyrille Vogel has noted, the multiplication of Masses was a consequence of the assimilation of the privatc Mass into the Celtic system of tariffpenance with its predilection for calculating satisfaction in numerical quantities. The monastic private Mass becamc a "good work"; one among orher ascetic exercises, through which the individual made satisfaction for the temporal punishment due to sir. ${ }^{124}$ Both "Scotists" and "'lhomists" were heirs to this tradition.

A recent Fcumenical discussion of the Reformation debate on the Mass has spoken of the tension between the "catabatic" and "anabatic" aspects of the Eucharist. The catabatic aspect (the Eucharist considered "from above" as the initiative of God) emphasises the uniqueness and gratuity of God's work (e.g. Melanchthon's sacramentum quod Deus exbibet nobis). The anabatic aspect (i.e. the Fucharist considered "from below" as a human response) emphasises that this act of God "docs not merely result in the response of human beings, but actually first makes that response possible and sustains it" (e.g. Melanchthon's sacrificizm eucharistikon) ${ }^{125}$ For the Scotists, both movements were effective ex opere operato. ${ }^{125}$ For the Thomists, however, the anabatic movement was effective ex opere operantis. Considered absolutely, the church's work could be only thanksgiving, memorial and intercession. In this respect Thomism came closer to Melanchthon's understanding of "eucharistic sacrifice" than Scotism. In locating the sole opts

${ }^{121}$ Isetloh, "Wert," 73-74; Oberman, Forerunners, 259.

${ }^{122}$ Iserloh, Die Eucharistie, $191 \mathrm{ff}$.

${ }^{121}$ Oberman, Forerunners, 250.

${ }^{124}$ Vogel, 241ff.; Power, Sacrifice, 42-44, 168-172.

${ }^{125}$ Ölsumenische Arheirskreis evangelischer und ksatholischer Theologen, "Das Opfer Jesu Christi und die Kirche," in Das Opfer Yesu Christi und sein Gegenteart in der Kirche: Klärungen zum Op) ferkarakter des Herrenmahls, ed. Lehmann \& Schlink (Göttingen, 1983), 232.

${ }^{126}$ Iserloh, "Wert," 67. 
operatum in the consecration, it also left room for rapprochement with Reformers, such as Luther and Melanchthon, who defended a kind of objective sacramental efficacy. As Iserloh has pointed out, Cajetan's writing on the Mass influenced the Cologne theologian Johannes Gropper, and Gropper's "Thomism" on the question of application seems to have commended itself to Bucer. ${ }^{127}$

One final point worth clarifying here is exactly what the "fruits of the Eucharist," (whether as a sacrament or as a sacrifice) werc understood to be. Fisher rejected Luther's description of the Eucharist as a testament and promise of the forgiveness of sins on the grounds that it made the sacraments of Baptism and Penance superfluous. The Eucharist was synaxis: the sacrament of the union with Christ and with God the Father through Christ. The blood of the Eucharist was not the Testament but the blood of the Testament. The Testament itself was the Gospel of the forgiveness of sins ratified by Christ's sacrificial death on the cross. It was the fountainhead not merely of the Eucharist but of all seven sacraments. ${ }^{128}$

Late mediaeval text-books such as Biel's Commentary on the Sentences described the fruits of communion as the increase of first grace, "by which the soul pleasing to God is nourished and grows in grace, so that it comes to perfection," ${ }^{129}$ It was admitted that the Fucharist forgave sins, but only in the sense that it remitted venial sins and preserved the recipient against mortal $\sin .{ }^{130}$ Here any disagreement between Luther and his opponents lay not so much in their understanding of the fruits of communion as in their understanding of the relationship between faith and regeneration and the status of the concupiscence remaining after Baptism as "sin." 131

Regarding the eucharistic sacrifice, Biel wrote that it benefited the whole

127 Jscrloh, "Das Tridentiner Messopferdekret in seinen Bcziehungen zu der Kontroverstheologic der Zcit," in Il Concilio di Trento e la Riforma cattolica (Rome, 1965) 2:409-412.

${ }^{128}$ Fisher, Assertionum defensio 5 (Opera 186-181, 186-187).

[2" Biel, Collectorium 4 d.9 q.2 a.I (Werbeck \& Hofma1n 4.1:325, I. 19-25), “...effectus eucharistiae non est prima gratia, qua iustificatur impius, sed illam praesupponit; et prima gratia sufficit ad saluten; ergo alia non tequiritur. Effectus enim manducationis eucharistiae est gratiae augmentum, qua anima Deo grata nutritur et crescit in gratia ut ad perfectionem venit." See also Altenstaig, Lexicon, 105a.

${ }^{1.30}$ Biel, Collectorium 4 d.12 q.2 a.4 (Werbeck \& Hofmann 4.1:381, 1. 5-9) quoting Innocent III, De sacro altaris mysterio 4.44 (PL 217:885), "Eucharistia si digne sumatur, a malo liberat et: conservat in bono, venalia delet et cavet mortalia." See also Altenstaig, Lexicon, 105a.

${ }^{131}$ Sec K. Froelich, "Justification Language in the Middle Ages," in Justification by Faitb: Lutherans and Catholics in Didlogue, ed. Anderson, (Minneapolis, 1985), 144-146. Aquinas, ST 3a q.79 a.3 distinguished between the virtive of the sacrament in so far as it contained the passion of Christ which was the fount and cause of the forgiveness of sins and its efficacy in so far as it was received by one conscious of mortal sin. A mortal sinner was spiritually dead and could thus not rcccive spiritual food. The sacrament was only for the living, i.e. those united to Christ. Cf, Luther, Groß3er Katechismus (BS 719, 1. 31-720, 1. 17). These passages suggest that, after differences in the terminology for the processus iustificationis had been taken into account, the differences between the two positions were not absolutely irreconcilable. 
church, "in obtaining various spiritual and temporal goods, and removing evil from those still on their journey to heaven, from those requiring purification [i.e. in Purgatory] and also by way of thanksgiving for those already in the state of bliss." 132 The Eucharist, in ocher words, made available to the church everything which Christ's sacrifice had obtained for it. In the case of the faithful departed it made available to them the satisfaction of Christ's death. ${ }^{133}$ Insistence on the necessity of faith in receiving the benefits of this sacrifice was common to Catholic apologists discussed here. Henry VIII, Schatzgeyer and Eck all clained that there was no necessary contradiction between the sacrificial character of the Mass and faith in the promise contained therein. ${ }^{134}$ Henry VIII did allow, as Biel had done, that the Mass might obtain the grace of faith for the unbeliever, since the passion and death of Christ had procured the grace through which the pagans came to faith by hearing the Word. ${ }^{135}$ As Clark points out, this is the context in which Melanchthon's objection to ex opere operato, sine bonu motu utentis is to be understood. The Scotists and their Nominalist counterparts had also claimed that for the sacraments to have their effect, only an absence of any impediment (i.e. the obex of active disbelief or of mortal sin) was nccessary. Attrition in candidates for Baptism and in mortal sinners might be transformed into contrition (and thus condign rather than congruent merit) by the grace of the sacrament. As Clark points out, this claim was made in relation to the sacraments Baptism, Penance and Anointing rather than the Eucharist. $^{136}$

\subsubsection{The Historical Development of the Mass}

The exidence for the Apostolic pedigree of the present Mass took the form of a cumulation of proof texts rather than a coherent historical argument. Emser, Clichtove, and Eck all cited the opinion of Isidore of Seville that the kernel of the Mass quo omnes bodie utimur, was celebrated by Saint Peter at Antioch. ${ }^{1.37}$ It was

${ }^{132}$ Biel, Collectorium A d.12 q.2 a.3 (Werbeck \& Holmann 4.1:38C, 1. 32-35), "... pro variis impetrandis, spiritualibus et temporalibus bonis, malisque removendis, et hoc tam viatoribus quam purgandis quatn etian beatis pro gratiarum actionibus."

137 Alterstaig, Lexicon 105a. 36:152f).

${ }^{131}$ Ibid., 15C-155; Schalzgeyer, Replica (CCath 37:68); Eck, De sacrificio 3.5 (CCath

${ }_{135}$ Henry VII, Assertio (Coath 43:154); Cr. Bict, Collectoriwm 4 d.12 q.2 a.21, (Werbeck $2 x$ Hofmann $4.1380,1.12-14)$ " $\mathrm{Nec}$ solun fructificat in bonis et iustis sed etiam in peccatoribus, pro quibus offertur, ut a peccatis convertantur."

${ }^{136}$ I.e. that attrition in infants prior to baptisin and in penitents might be transformed into contrition (and thus condign rather than congruent merit) by the grace of the sacransent. Sec Clark, 353-356 \& above, p. 26.

${ }^{13 \%}$ I.e. the Hanc oblationem and the consecratory prayers. See Isidore of Scville, De ecclesiasticis officiis 1.15 "De missa et orationibus" (PL 83:752). Emser, Missae assertio (CCâth 28:8); Clichtove, Propugnaculum, 18a; Eck, De sacrificio 2.1 (CCath 36:80). For this, and for the majority of patristic references to the apostolic origin of the Mass, all three cite Doctrinale antigutitatem fidei 
then sct dowt in writing by James, brother of the Lord, and subscquent additions were made by Basil. This information, from the "Sixth synod" (i.e. the Council of Trullo 692) and excerpted in the Decretum Gratiani, was a common-place of the scholastic commentarics. ${ }^{138}$ Another proof-text cited by a number of the Catholic apologists came from the 5th cent. Passio or Martyrium Sancti Andrede. It the account of the apostle's martyrdom the Passio had Andrew speak of his daily "offering of the spotless Lamb." Lepin notes that during the Middle Ages these words were often cited as the sententic of Andrew himself. ${ }^{139}$ According to Eck, no less faith should be given to this story about one of the colmmnes ecclesiae, than to the work of any pagan historian. ${ }^{140}$

Explicitly scriptural evidence for the correspondence between the structure of the apostolic Mass and the present one was found in 1 "limothy 2:1 which spoke of "supplications, prayers, intercessions and thanksgivings" (obsecrationes, orationes, postulationes ac gratiarum actiones) in the context of communal prayer. Augustine had first used the passage in this way. According to Jungmann, most mediaeval commentators on the Mass attempted to locate this structure, and indeed this sequence, in the Mass of the Roman rite. The Catholic apologists who citcd this locus, did not attempt to apply it so rigidly, but they did cite it as evidence for the Apostolic origin of the present Mass. ${ }^{1+1}$

Another commonplace of Catholic "histories" of the Mass in the Reformation period was the suggestion of the Hebraist Reuchlin ("Capnio") that the Latin missa had come from the Hebrew root mas (cf. Deut. 16:10) meaning "an offering made to a higher Lord on account of the personal duty owed him." Reuchlin offered $\lambda \epsilon i r o u p \gamma i$ o as the Greek translation ${ }^{122}$ Since it was believed that

(c1425) by Thomas Netter ("Waldensis" i.e. of Saffron Walden) (1372-1431) who had defended the historical development of the Mass against the Wycliffites. The Do:Lrinale, in circulation since the Council of Basel, was first printed in October 1521. See Cliclitove, Antilutherus 2.8 (68b); Propugnaculum, 15a; Eck, De sacrificio 3.10 (CCath 36:189); Emser, Missae assertio (CCath 28:8); Netter, Doctrinale 3.4.28, 36, 38 (Opera 3:197-205, 245-251, 259-265).

${ }^{138}$ Fisher, Assertionum defensio 6 (Opera 193, 195); Clichtove, Antilutberus 2.8 (68a); Emser, Missae assertio (CCath 28:8); Eck, De sacrificio missae 2.1 (CCath 36:81). See Decretum Gratiani 3 de consecr. dist.1, c.47 (Friedberg 1:1306); Council of Trullo, can.32 (Mansi 9:957).

${ }^{139}$ Lepin, 61-62.

${ }^{140}$ Eck, De sacrificio 2.3 (CCath 36:88). See also Schatzgeyer, Scrutinitum (CCath 5:88); Emser, Missate assertio (CCath 28:19).

${ }^{111}$ Emser, Missac assertio (CCath 28:8); Clichtove, Antilutherus 2.8 (69a); Propugnaculum, 7b. See Augustine, Epistola 149.2.12 16 (PL 33:635-637); Nettcr, Doctrinale 3.4.36 (3:247); Jungmann $1: 114$.

${ }^{142}$ Reuchlin, De rudimentis bebricis, 289b; quoted in CCath 36:84, n. 6. According to Iscrloh, Die Eucharistie, 93, Eck, Clichtove and Jacques Lefèvre obtained this material independently from Renchlin. See also Eck, De sacrificio 2.2 (CCath 36:84f); Emser, Canonis defensio (CCath 28:48); Fisher, Assertionum defensio 6 (Opera 204). In his earlier Missde assertio (CCath 28:28, 51) Emser identified what is probably the correct origin of the term, the mittendo by which the catechumens and peniterts were dismissed from the Eucharist before the celebration of the Lord's 
the Mass had been celebrated in Hebrew by the Apostolic Church, and only subsequently translated into Latin and Greek, the persistetice of the allogedly Hebrew missa, demonstrated that the apostles had understood the Mass as a sacrifice.

Ps.-Dionysius, De bierarchit ecclesiastica was regarded by the Catholic apologists as their most substantial evidence for the apostolic origin of the Mass. Despite the doubts cast on the work's provenance by Valla (and subsequently Erasmus), I have been able to find no evidence of a Catholic apologist who doubted that the author was the disciple of Paul and thus an invaluable witness to the belief and practice of the apostolic church. ${ }^{143}$ The French scholar Jacques Lefèvre d'Étaples ("Stapulensis") had schenatised the structure of the apostolic Mass which he believed he found in De hierarchia ecclesiastica. ${ }^{144}$ Leferyre compared this with the structure of the present Mass in order to demonstrate that the mos bodie conformed almost exactly with the mos apostolicus. This outline was subsequently reproduced both by Clichtove and Eck, and we shall meet it again when we discuss Bucer's use of it in Constans defensio. ${ }^{145}$

Along with this "apostolic" material, the apologists produced a collcction of sententiae from the church of the second and third centuries. We have noted the use of Irenaeus's Adversus baereses and Cyprian's Epistold 63 above. Eck and Fisher quoted psendo-Clementine canons on the celebration of the Mass. ${ }^{146}$ Eck and the Confutators appealed to Ignatius' Epistola ad Smymenses 8, via Ambrogio Traversari's Latin translation which used neque offerre, neque sacrificium imolare,

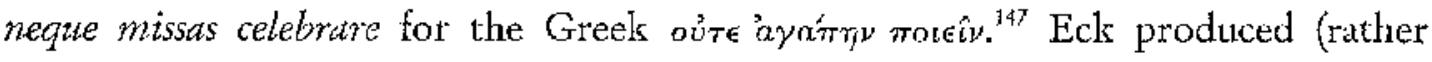
uncritically) a series of references to oblationes in the works of Tertullian. ${ }^{1+8}$ Often the mere appearance of a sacrificial reference in was enough to convince Eck and

Supper proper. Here Emser cited Isidore, Elymologiae 6.19 (PL 82:252) and Renigius of Auxerre, De celebratione missae (PL 101:1246); Cf. Altensiaig, Lexicon 197b-198a.

${ }^{143}$ Polman, 327 refers to Cochlacus, Assertio pro Hieronymo Emsero contra Lutberum... (1521) in which the atuthor claimed that he would refrain from using Ps.-Dionysius as in act of liberality towards his adversarics. See also Clichtove's work, Quod operd Dionysio attribute, sint Dionysii Areopayilate et nun allerius (1517) in Massaut, Critique ef tradition à la veille de la Reforme en France (Paris, 1974), 188-229.

${ }^{114}$ Ps.-Dionysius, De hierarchia ecclesiastica 3.2 (PG 3:425-428); The outline appeared in Theologia vivificans, cibus solidus... (Paris: in alma Parisiorum academia ,1515), 63b. In this anthology, Ambrogio Traversari's translation was published with Lefèvre's "scholia" and Clichtove's Annotationes ad literam. For publication history see, Froelich, 33, 36 and Massaut, 179-189.

${ }^{145}$ Eck, De sacrificio 2.8 (CCath 36:113). Sec also Clichtove, Antiluthertus 2.8.4-6 (69a-69b) Propugnaculum, 8a. See below ch. 10, p. 194.

14t Eck, De sacrificio 2.9 (CCath 36:114-116); Fisher, Assertionum 6 (Opera 192). See e.g. Decretum Gratiani 3 de consecr. dist.2, c.23 (Friedberg 1;1321).

${ }_{147}$ Eck, De sacrificio 2,3 (CCath 36:90-91); Fisher, Assertionum defensio 6 (Opera 192); CCA 24 (CCath 33:167) quoting from Lc.lc̀ve, Theologia wivificans, 215b. See PיG 5:713-714.

${ }^{148}$ Eck, De sacrificio 2.3 (CCath 36:91-95). 
other Catholic apologists, that a second, third or fourth century father had adhered to a 16 th century Catholic theology of eucharistic sacrifice.

While it was tactically prudent for the Catholic apologists to emphasise the apostolic origin of the present Mass, they recognised that from the late fifth century, papal legislation recorded additions to the Roman rite. This had also been recognised by the mediaeval commentators. ${ }^{142}$ Two passages in the Decretum Gratiani suggested that the greater part of the Roman Canon had an early origin. A mutilated fragment from Ambrose, De sacramentis 4 reproduced a portion of a prayer with obvious similarities to the Roman Canon. Echoing the Canon's Unde et memores it referred to, "this spotless victim, this spiritual (rationabilis) victim, this bloodless victim, this holy bread and the cup of eternal life" and prayed that God would receive this offering through his angels at his heavenly altar. ${ }^{150}$ The second cxtract from “Augustine" (i.e. Paschasius Radbertus) De corpore et sangmine Domini mentioned the formula adscriptam, ratam, rationabilem from the Canon's Quam oblationem. Again this seemed to indicatc that Augustine had used a prayer like the Canon. ${ }^{151}$

Clichtove's Antilutberus listed the various additions made by popes Leo and Gregory. ${ }^{152}$ Ennser argued that evidence of later of papal modifications to the Canon should be compared to the passage in John 7:22: "Moses gave you circumcision not that it came from Moses, but from the fathers." The popes who had issued legislation concerning the Mass were, like Moses, merely confirming, or adjusting, what was already handed down from the apostles. ${ }^{153}$ Clichtove claimed that, despite the variety of its authors, "the Holy Spirit, the same supreme architect and builder of the whole structure was in them all."154

\subsubsection{The Memorial of the Faithful Departed and the Saints}

"The prayers in the Canon which spoke of "offering" for the faithful departed were defended with an asscrtion of the apostolic origin of this practicc.

1.19 E.g. Durandus, Rationale 4.1.3-8, 6.1; Innocent IT, De sacro altaris mysterio 3.2 (PL 217:840); Netter, Doctrinale 3.4.38 (Opera 3:261); Biel, Fxpositio 15C (Oberman \& Courtenay $1: 121-122)$.

150 Decretum Graitani 3 de consecr. dist.2 c.55 (Friedberg 1:1334). See Ambrose, De sacramentis 4.5.21 (PL 16:462f); Fck, De sacrificio missae 2.2, 2.8 (CCath 36:86, 111); Emser, Canonis dcfensio (CCath 28:46 \& passim); Fabri, Malleus 4 (48b).

${ }^{151}$ Decretum Gratiani 3 dc consccr. dist.2 c.72 (Friedberg 1:1342). See Paschasius Radhertas, De corpore et sanguine domini (PL 120:1312); Emser, Canonis defensio (CCath 28:63, 76).

${ }_{1.52}$ Clichtove, Antilutberus 2.17.3 (85b). Here he acknowledges his debt to Biel, Expositio 15B (Oberman \& Courtenay 1:121-122) \& Bartolomeo Platina, Liber de vita Christi ac Pontificum omnium (Taurisoe: impensa Ioannis Uerculensis, 1485).

${ }^{153}$ Emser, Canonis defensio (CCath 28:41-44).

${ }^{154}$ Clichtove, Antilutherus 2.17.2 (85b), "Tum quod in illis omnibus, vnus \& idem erat supremus archicectus $\&$ author torius fabricae, spiritus sanctus." 
Augustine's De cura pro mortuis gerenda stated that even if there were no instruction from Scripture to pray for the dead, the authority and custom of the church were such that no one following it could err. Ps.-Dionysius, De bierarchia ecclesiastica 3.9 and 7, Isidore, De ecclesiasticis officiis 1.18, and [Ps.J-John Damascene, De iis qui in fide dormierm were cited in a similar vein. ${ }^{135}$ Tertullian, De corona 3.2 spoke of "making offering for the dead on their anniversaries." 156 The description of Monica's death in Confessions 9.11 gave warrant for offering "the sacrifice of the price [sc. of our redemption]" for the dead. ${ }^{157}$

As we shall see, the custon of prayer for the dead was notionally separable from the doctrine of Purgatory. In practice, however, debate on the former almost invariably involved discussion of the latter. As Clichtove acknowledged in his Antilutherus, one of his richest sources of patristic material on Purgatory was Biel's Sacri canonis missae expositio. ${ }^{158}$ Three scriptural passages were traditionally cited in support of the doctrine of Purgatory. 2 Maccabees 12:41-46 described Judas Maccabaeus' offering of an expiatory sacrifice for his fallen comrades at arms. ${ }^{159}$ Matthew 12:31-32 referred to blasphemy against the Ioly Spirit which would be forgiven neither in this age nor in the age to come. It was concluded from this that there was an age to come (i.e. Purgatory) in which sin could be forgiven. ${ }^{160}$ Finally, 1 Corinthians 3:11-15 referred to three buildings, one of precious stones, onc of wood and one of hay and stubble built on the foundation of Christ. On judgment day these would be tested by fire, and "if any man's work shall be burned up, he shall suffer loss; but he himself shall be saved, yet as through fire." This, it was

${ }^{155}$ Augustine, De cura pro mortuis gerenda 1.3 (PL 40:593). See Clichtove, Antilutherus 2.27.5 (105b); Eck, De sacrificio 2.2 (CCath 36:87); Fisher, Assertionis confutatio 37 (Opera 717). Lsidore, De ecclesiasticis officits 1.18 (PL 83:757). See Clichtove, Antilutherus 2.8.6 (69b); Propngnaculum 18a; Ech, De sacrificio missae 2.3 (CCath 36:93); Emser, Missae assertio (CCath 28:210). Ps.-Dionysius, De bierarcbia ecclesiastica 3.9 \& 7.2 (PG 3:464, 556). See Clichtove, Antilucherus 2.8 .6 (69b); Propugnaculum, 18a; Fisher, Assertionis confutatio 37 (Opera 726). [Ps.]-John Damascene, Sermo de iis qui in fide dormiermt (PG 95:249BC). See Clichtove, Anitilutherus 2.27.5 (105b-106a). With the exception of Isidore, wll of the above sententiae are also cited in the discussion on prayer for the dead in Biel's Expositio 56H \& O (Oberman \& Courtenay 3:375, 381).

${ }_{156}$ Tertullian, De corona (PL 2:98f). See Eck, De sacrificio 2.3 (CCath 36:92).

157 Augustine, Confessio 9.11 (PL 32:775). Sec Lick, De sacrificio 2.7 (CCath 36:108); Clichtove, Propugnaculum, 18a; Emser, Missae assertio (CCath 28:21).

${ }^{158}$ Clichtove, Antilutherus 2.26 (106b). See Bicl Expositio 56-57 (Oberman \& Courtenay 2:369-414). His other major source was Netter's Doctrinale 3.4.50 (Opera 3:270-277). In addition, Clichtove, Antilutherns 2.26-28 (102a-108b) produccs Bernard, Scrmones in Cantica 26 \& 66 (PL 183:903-912, 1099-1100); Gregory Dialogi (chap. not specified, but see PL 77:416-421); Jerome, In Esaiam 18 ad c.66:24 (PL 24:703); Aquilas, Contra errores Graecorum 2.40; "Concilium Cabillonense" 2, c.39 in Decreitum Gratiani 3 de consecr. dist.1 c.72 (Friedberg 1:1313); Innocent III, De sacro altaris mysterio 5.5 (PL 217:892); I Hugh of Saint Victor, De Sacramentis 2.16 (PL 176:579596); Ambrose, De obitn Theodosii Imperatoris (PL 16:1461-1462).

${ }^{15 y}$ Clichtove, Antiluthems 2.26 (102b). For a history of the exegesis of the following passages, see Le Goff, La natissance du Purgatoire (Paris, 1981), 64-67.

${ }^{160}$ Clichtove, Antilutberis 2,26.3 (102b); Eck, Enchridion 25 (CCath 34:260-261). 
claimed, referred to the purgatorial firc. ${ }^{161}$

In the second two cases, the exegesis was influenced primarily by Augustinc. It was he who had claimed in De civitate Dei 21.24 that the "age to come" of Matthew 12:31-32 would not have been mentioned, "unless therc were some who receive forgivencss in the age to come though not in this age." "The beneficiaries of this forgiveness were, "those who have been reborn in Christ and whose life in the body has not been so evil that they are judged unworthy of such mercy [i.e. the prayer of the Church], and yet not so good that they are seen to have no need of it," An' Augustitie considered 1 Corinthians 3 in the Enchiridion 68-70. Here he observed that it was not beyond belief that, "a certain number of the faithful are more belatedly or more speedily saved, through a sort of purificatory fire (ignem quemdam purgatorium) the more or the less they have set their affections on the good things that perish." 163

As Jacques Le Goff points out (and Bucer would arguc) Augustine's observations on the purgatorial fire were advanced with uncertainty and were marginal to his central concerns: e.g. the relationship between faith and works, and the nccessity of spiritual progress on the way to eternal salvation. ${ }^{164}$ Nevertheless the Augustinian passages on the subject which found their way into the anthologies and text-books of twelfth and thirteenth centuries where decisive for the reception of Purgatory by the Reformers' Catholic opponents. ${ }^{165}$

Two passages, in particular, defined those dead for whom prayer, alms and the offering of the Eucharist were beneficial. Augustine's Encbiridion described three classes of the baptised dead: those so confirmed in goodness that they had no need of these charitable works of the living; those so confirmed in evil as to be incapable of benefiting from them; and those neither so good nor so bad that one might not preclude the possibility that such works would benefit them. For the very good (valde boni) such works of the living would count as thanksgiving. For the very bad (valde mali) they were of no help but did at least console the living. For the intermediate category they were "propitiations." As such these good works might obtain for them either a full remission or at least a "more tolcrable damnation." In the same place Augustine observed that while the offering of alms

${ }^{161}$ See Clichtove, Antilutberts 2.26 .5 (103a); Fisher, Assertionis confutatio 37 (Opera 723); Eck, Enchridion 25 (CCath 34:260).

${ }_{152}$ PL 41:742.

${ }^{153}$ PL 40:265, "T'ale aliquid etiam post hanc vitam fieri, incredibile non est... nonnullos fideles per ignem quemdan purgatorium, quanto minusve bona pereuntia dilexerunt, tanto tardius citiusque salvari." See also De civitate Dei 21.26 (PL 41:745).

${ }^{15}$ Le Goff, 62.

${ }^{155}$ See e.g. Peter Lombard, Sententide 4 d.45 a.2-5 (PL 192:948-950),

${ }^{146}$ Enchiridion 110 (PL 40:283). See also De cuta pro mortuis gerenda 1.1-2 (PL 40:592-593). 
and the "sacrifice of the mediator" might "relieve" the dead in the interval between their death and the day of judgment, they would only be of help to those who while alive had behaved with sufficient merit that such works would benefit them. ${ }^{167}$

The eucharistic memorial of the saints tended to be subsumed under the question of the veneration of the saints in Catholic apologetic. Emser's systematic defence of the Canon in Canonis missae defensio forced him to consider the place of the saints in the Eucharist specifically. He defended the words of the prayer Communicantes by explaining that, "the Canon does not call upon the names of the saints placed there, but on God the Father in their name and in their memory." 168 Here he cited the example of 2 Chronicles 19:34 and Daniel 3:35 where God's aid is sought for the salke of his servant David, or his servants Abraham, Isaac and Jacob. ${ }^{169}$ He also cited Augustine's discussion of Exodus 32:10 in which God tells Moses to leave him so that he may destroy the children of Istael in his anger. Augustine comments:

Whether these were the words of someone giving an order or of someone making a request, they seems absurd. God could destroy them even if Moses did not want him to... Thus the obvious sense is that by these words God signifies that those whom he loves have sway with him, and that when our [sc. lack of] merits hinder us from being loved by him, we can be assisted by the merits of those whom God loves. ${ }^{\text {tro }}$

Elscwhere Enser cited Augustine's De civitate Dei 22.10: "we do not erect altars on which we make sacrifice to the martyrs, but wc immolate sacrifice to the one God - the martyrs' and ours." ${ }^{171}$ As we shall see, Augustinian sententiae in a similar vein would form the basis of the rapprochement between Bucer and his Catholic collocutors during the period of the colloquies.

${ }_{167}$ Enctiritlion 110 (PL 40:283) quoted in De card pro monuis gerenda 1.2 (PL 40:593). ScL Clichtove, Antilutherus 2.27.5 (106a).

${ }^{1: 5}$ Fnscr, Canonis defensio (CCath 28:67), "Neque enim canon posita hic divortnn nomina invocat, sed Doum patrem in eorum nomine et menoria."

${ }^{169}$ Tbid.

${ }^{170}$ Augustine, Quaesitiones in beptatetuchum 2.149 (PL 34:646).

${ }^{171}$ Augustine, De civitate Dei 22.10 (1'T, 41:772). See Emrser, Missae assertio (CCath 28:16); Clichtove, Propugnaculum 14b. 


\section{THE USE OF TRADITION AMONG THE REFORMERS}

\subsection{Introduction}

Irena Backus speaks of the Reformers' (specifically Zwingli's and Bucer's) use of the fathers as a process of "neutralisation" and "appropriation." In the first case the Reformers sought to demonstrate that the extra-Scriptural texts on which the Catholics drew did not support the Catholic casc. In the second case, the Reformers sought to demonstrate patristic support for their owtl case.

In the case of neutralisation, wresting the fathers from the hands of the Catholics could be seen as a sort of praeparatio evangelica: clcaring the way for the sovereign authority of the Gospel. ${ }^{2}$ Why, however, should the Reformers need to appropriate the fathers for their own case? First of all, the fathers offered a kind of fortification for the weak in faith. Zwingli claimed that the witness of the fathers assured the weaker brethren that he was not guilty of doctrinal novelty, and that he had carefully checked his interpretation of Scripture against the traditional authorities. ${ }^{3}$ Here, again the fathers' task was to clear the way. They were "mills" in comparison with the solid food of the Gospel. Howcver, Fraenkel argues that divisions within the Reformation forced Reformers such as Melanchthon to develop a positive understanding of Tradition and the teaching authority of the church; one which attempted a via media between the correlations of church and Scripture advanced on the Reformation's "left-wing" and those advanced on the Catholic side. ${ }^{4}$ Against the Catholics, Melanchthon insisted on the Word's historical and theoretical priority over the church." Against the Anabaptists he insisted that the writing of the fathers demonstrated to the contemporary church both that it had received apostolic doctrine and bow it had received it. At any point in the church's history it should be possible to identify the existence of ministers of the Word who preached the Gospel handed from generation to generation. ${ }^{6}$ Thus,

'Backus, "Martin Bucer and the Pacristic Thdition," in Martin Bucer and Sixteenth Century Evrope, ed. Kricyer, 56. These largely correspond to the "negative" and "positive" uses of the fathers proposed ty Grcensladc, The Fnglish Reformers and the Fathers of the Church (Oxford, 1960). The model of "dcparcntification" has been suggested by Hendrix, "Deparentifying the Pathers: the Reformers and Patristic Authority," in Auctoritas Patrum, ed. Grane, 55-68. Howcver this seems to me to make essentially the same point as Backus and Greenslade: i.e. that an insistence on Scripture alone did not prevent the Reformers from using the fathers as examples of what they considered to be sound exposition of the Scriptures. ed. Backus, 600 .

${ }^{2}$ M. Schulze, "Martin Luther and the Church Fathers," in Reception of the Cburch Faibers,

${ }^{3}$ De vera et falsa religione (CK 89:816).

+ Fraenkel, Testimonia Patrum the Function of Patristic Argument in the Theology of Pbilip Melancthon (Gencva, 1961).

${ }^{5}$ Disputatio de autoritate ecclesice (CR 12:428f); Frtienkel, Testimonid, 61.

'Indicium contra Anabaptistus (CR 1:962); Fraenluel, Testimonia, 186. 
alongside the canon of Scripture, there a successio doctortum, and a gift of interpretation; though not one tied to certain persons or offices as in the papal church. This T'radition was identifiable in (though not identical with) the creeds, the decisions of the councils and the writing of the fathers. When confronted by his Catholic opponents with the dictum Augustini (evangelio non crederem etc.) Zwingli had surmised that Augustine had either written these words unreflectively, or that the had meant that he would not have believed the preaching of the Gospel had it not been written down first. ${ }^{8}$ Melanchthon, however, was able to appropriate the dictum for the Reformation. In a disputation on this passage, Melanchthon compared the authority of Tradition with that of a witness in a court. The judge could not know a story to be true unless there were witnesses to it, but it did not follow from this that the witnesses could change the story and continue to be witnesses to the truth. Thus the church was not greater than, or prior to, the Gospel. However insolar as the fathers and other doctors of the church testified to the truth, they could be said to mediate betwcen the truth and those they sought to persuade."

We might call this kind of appropriation of the fathers "magisterial" in so far as it appeals to the authority and succession of the church's teaching ministry along-side the Scripture, but under the authority of the Word or the Spirit. Bucer's view of the role of Tradition would take a similar course in the 1530s. The would also attempt to define the nature of the consensus ecclesiae which bound the church of the present age to that of every previous generation back to the time of the apostles, and, indecd, of Abel.

\subsection{The Reformers' Use of the Fathers in the Debate on the Sacrifice of the Mass}

\subsubsection{Questioning the Authenticity of the Authorities}

Humanist scepticism about the authenticity or provenance of certain patristic texts became a way of neutralising the Catholics' authorities without having to answer them. Oecolampadius heaped scorn on the reliability of the attributions in the Decretum Gratiani. ${ }^{10}$ When the theologians of the Bishop of

${ }^{7}$ De dignitate studii theologici (CR 11:326f.); Declamatio de dono interpretalionis (CR 11:645ff); Fraenkel, Testimonia, 152f, 225.

8 Zwingli, Apologeticus arcbiteles (CR 88:293) "Relinquitur crgo vel Augustinum fortius quam consultius id dicti pronunciasse, aut nunquan crediturum fuisse, si antequan scriptum esset evangeliun, ipsum praedicari audivisset."

${ }^{9}$ Disputatio de autoritate ecclesiate (CR 12:482); Fraenkel, Testimonia, 225-235.

10 Oecolampadius, Ad Billibaldum Byrkaimerum de re eublaristide responsio (Zurich: Froschauer, 1526), d2b, "Minime enim turum fucril ex consarcinatoribus illis multa confuse, perperamque ac falsis titulis confundentibus depromerc..." 
Constance cited Ps.-Dionysius as a witness to the apostolic Mass, Zwingli referred them to Erasmus' Annotationes in Novmm Testamentum. ${ }^{11}$ The provenance of Ambrose's De sacramentis, cited as evidence for the antiquity of the Roman Canon, was recognised by neither Zwingli or Oecolampadius. ${ }^{12}$ The latter also questioned the authenticity of De coena domini, attributed to Cyprian and used by both the Catholics and Melanchthon. ${ }^{13}$

\subsubsection{Sacrificium}

The Catholic appeals to typology and prophecy were also rejected by the Reformers. Melanchthon wrote in his Apologia, "things are going well for our opponents when we allow ourselves to be overcome by allegories. It is established, however, that allegories do not offer firm proofs." ${ }^{14}$

The Reformers nevcrtheless attempted (where possible) to appropriate the types and prophecies. Zwingli contended that Melchizedek had not "offered" bread and wine in the sense that he had sacrificed them. Rather, he had, "olfered" (protulit) them to Abraham, i.e. to eat and drink. 7wingli pointed out that proferre was used even in the Old Latin version of Genesis 14:18 quoted in Ambrose's De sacramentis, (though he did not remark upon the fact that the same passage referred to Melchizedek's exercise of priesthood as a type of Christ at the Last Supper). According to Zwingli, the genuine relationship between Christ and Melchizcdek lay not in the "offering" of bread and wine, but simply in the fact that they had both exercised a priesthood of the most high God in accordance with Hcbrows 68 7.15

${ }^{11}$ Zwingli, Christilicbe Antwort (CR 90:219). Cf. Erasmus, Annotationes, 225 (on Acts 17:34) followed by a discussion of the identity of the genuine Dionysius.

12 Zwingli, De canone (CR 89:567); Oecolampadius, Ad Billibaldum Pyrkairnerum, d3a, "Ambrosii librum de sacramentis uc teruncium quidem ualere autumnat: imo liber ille qui circumfertur Ambrosij non cst, scd cognati eius, qui sententias Prosperi nomine Augustini Rhomanis Potificibus ucnditauit. Scripsit quidem Ambrosius librum de Sacramentis, qui utinam extaret: nam illius \& Augustinus..." Augustine, Retractationes 4 (PL 16:427 -435) rejected the attribution to Ambrose but defended the work's catholicity. Here is the answer to Old, 297 who expresses his puzzlement at the Reformers' apparent failure to recognise, on the basis of $D e$ Sacramentis, that objectionable elements in the Roman Canon existed in at least the late 4th cent. For a contemporary discussion of the authenticity of this work see B. Bottc, cd, Ambroise de Milan: Des sacramtzts: Des mystères, new ed. (Sources chrétiennes, 25bis) (Paris: Éditions du Cerf, 1961), 725.

${ }^{13}$ Occolampadius, Ad Billibaldum Pyrkbaimerum, a3b. Oecolampadius did not say on what grounds he rejectcd this attribution. De coena domini was in fact a chapter of Einaldus Bonaevallis (1156) Liber de cardinalibus opcribus Christi, "De coena domini, ct prima institutione consummantis omnia sacramenta" (PL 189:1641-1650). Discussion of the attribution of this work in PL 189:1510. According to Polman, 122, n, 4, included among the works "falsely ascribed to Cyprian" in Erasnuus' 1530 edition. Quoted, however, in $\Lambda$ CA 24 (BS 371).

${ }^{14}$ ACA 24.35 (BS 360) "Bene cum adversarijs agitur, si patimur nos vinci allegorijs. Constat autem quod allegoriae non pariunt firmas probationes,"

${ }^{15}$ Zwingli, Christliche Antwort (CR 90:187-195). 
Turning his attention to Malachi 1:11, Zwingli exanined the text in the light of two passages from Augustine's De civitate Dei 18.35 and Adversus Inddeos 9.12. ${ }^{16} \mathrm{He}$ argued that the prophecy referred to the sacrifice of Christ on the cross. It was offered "in every place" because it was fruitful to all the ends of the earth. This, he wrote, was what Augustine meant when he said that the sacrifice of Christians was offered cverywhere. ${ }^{17}$ Z,wingli followed this with two passages from Tertullian's Contra Marcionem: firstly, book 3.22 in which the sacrificium mundum of Malachi 1:11 was described as, "the proclamation of glory, blessing, praise and hymns"; and secondly, book 4.1 where it was described as, "simple prayer from a pure conscience." He also adduced Jerome, In Malachiam prophetam 1 which described the pure offering as the prayer of the saints and the "ceremonies" of the Christians. ${ }^{18}$ Melanchthon's Apologia argued that the incense and pure offering of Malachi 1:11 were the prayers, witness, and good works of those who had received the name of Christ. This sacrifice was offered in omni loco as a consequence of the preaching of the Gospel. Thus the language of "eucharistic sacrifice" referred to the worship of the New T'estament in general, rather than the Supper in any exclusive sense. $^{\text {t9 }}$

The inge sacrificium of Numbers 28 and Daniel 12:11 likewise referred not to the outward ceremony of Christian worship but to the death of Christ and the preaching of the Gospel. Through these the flcsh of the old Adam was mortified and new and eternal life began in the baptised. ${ }^{20}$

However, even in his carlicst works against the received understanding of eucharistic sacrifice, Luther admittcd that the sacrificial vocabulary of the Roman ritc might once have had a legitimate significance. He also suggested how this language might be reinterprcted in the present day. In Sermon won dem newen Testament, he noted that Acts 4:34 spoke of the distribution of and sharing of goods in the early Christian community, and that 1 Corinthans 11 suggested a specifically eucharistic context for this. 1 Timothy 4:4-5 gave instruction that all food be blessed with prayer, and, according to Luke 22:17, this was what Christ had done at table. These practices, Luther argued, survived in the collects and offertory prayers of the minor Canon (i.e. the offertory prayers preceding the Preface and the "major" Canon) where the priest raised the unconsecrated host to God on the paten

16 Augustine, De civitate Dei 18.35 (PL 41:594); Adversus Iudacos (PL 42:60ff). I 'iscussed in CR 90:195-205.

${ }^{17}$ Tbid., 197.

: Tertullian, Contra Marcionem 3.22 (PI. 2:382), "...gloriae scilicet relatio, et benedictio, et laus et hymai"; ibid, 4.1 (PL 2:322), "... scilicet simplex oratio de conscientia pura"; Jerome, In Malacbiam 1 (PL 25:1551).

${ }^{17} \mathrm{ACA} 24.25-33$ (BS 359).

${ }^{20}$ Ibid., 24.34 (BS 359-360). 
while the offertory hymn was sung and the people made their offering. Here it was not the sacrament which was offered to God, but food and goods. God was thanked for them and they were blessed for the use of the needy. ${ }^{21}$ These works of charity were among the spiritual sacrifices that had replaced the external sacrifices of the Old Law. In the Mass, Christians offered a sacrifice of prayer, praise, thanksgiving and of themselves. They trusted in the promise of Christ that he was wherever two or three were gathered in his name (Mart 18:20), and they laid their sacrifices on Christ who presented them to the Father as the church's high priest (Heb 9:24; Rom 8:34), 'Thus:

from these words we learn that we do not offer Christ, but that Christ offers us. And in this way it is permissible, indeed, profitable to call the Mass a sacrifice; not on its own account, but because we offer ourselves with Christ; i.e. we lay ourselves upon him and his testament with a firm faith, and appear before God with our prayers, praise and offering in no other way than through him and through his mediation, and doubt not that he is our priest or minister in heaven in the presence of God. ${ }^{23}$

He cautioned, however, that this was not to be mistaken with notions about the opus operatum and the opus operantis. No special merit was to be attached to the prayer of the priest celebrating the Mass. Rather each Christian might exercise his or her common priesthood and nnake intercession through the mediation of Christ the high priest. ${ }^{24}$

Despite the echoes of Augustine's De civitate Dei 10.20 in the passage quoted above, Luther seems to have made no explicit attempt to correlate these early insights with the testimony of the patristic church or that of the wider Christian Tradition. 1 t is unclear whether his conclusions about the original significance of the collects and the offertory vocabulary of the Canon were based on the Scriptural passages he had quoted, or whether they came from some other source. Like other mediaeval commentaries, Biel's Sacri canonis missae expositio (which Luther had read) showed only a vague awareness that the offertory prayers of the minor Canon might once have referred to a collection of food and goods. Uppermost in Biel's mind wcrc Mass-stipends, Mass-paraphernalia (e.g. candles) and the "spiritual offerings" of the faithful. ${ }^{25}$

${ }^{21}$ Sermon von dem neuen Testament (WA 6:366, 14-19).

${ }^{22}$ Ibid., 365. See also De captivitate (WA 6:5241).

${ }^{33}$ Sermon won dem newen Testament (WA 6:369).

${ }^{24}$ Tbid., $368 f f$.

25 Bicl, Expositio 16C (Oberman \& Courtenay 1:130ff). See H. Degering, Luthers Randbenerkung zu Gabriel Biels "Collectorium in quattuor hibros sententiarum" und zu dessen "Sacri canonis missae expositio," Lyon 1514 (Weimar, 1933), 19-20. Sce also Durandus' comments on the 
In his Apologia Melanchthon confirmed Luther's intuitions by appealing to the Canons of the apostles. ${ }^{26}$ This work, wrote Melanchthon, spoke of those present bringing forward bread and wine and other offerings. Some of these offerings were consecrated, some eaten, and what was left over was distributed to the poor. This, however, did not lead to his opponents' leves coniecturae about application ex opere operato. ${ }^{27}$ Melanchthon regarded his opponents' use of Reuchlin's etymology of missa as a vulgar attempt at erudition. ${ }^{28}$ Even if Reuchlin's etymology was correct, Melanchthon argued, it referred to the collected gifts of the people rather than some privileged sacerdotal offering. ${ }^{29}$ Where the fathers were not referring to material offerings brought by the faithful, references to sacrifice in the context of the Lord's supper were to be understood in terms of the sacrificia eucbaristika of the reconciled. ${ }^{30}$ In this respect Melanchthon referred on a number of occasions to the "Greek Canon" (i.e. the Liturgies of John Chrysostom and Basil). The Greek Canon referred, for example, to the offering of prayers, supplications and unbloody sacrifices for the people. It also spoke of offering spiritual and unbloody worship. It was clear, wrote Melanchthon, that these liturgies were referring to the

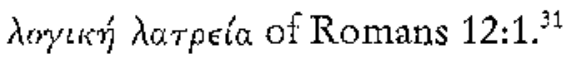

Oecolampadius developed the discussion of the early church's material offerings in a rather different direction. He suggested that these "offerings" referrcd to an external offering of bread and wine in addition to the collection and dedication of food and alms. As we have already noted, Eck and Fabri had access to a Latin translation of at least the fourth book of Irenaeus Adversis baereses. According to Oecolampadius, they had produced this at the Disputation of Baden in 1526 in an attempt to prove: "the presence of the body of Christ in the bread, and a sacrifice in the church for the living and the dead." ${ }^{32}$ In De genuina verbortum, Oecolampadius argued that Irenaeus's references to the "new offering of the New Testament" instituted by Christ in the Supper had to be understood in the context

offertory in Rationale 4.30.4-9 where the material offerenda of the pcople are distinguished from the priest's offering of himself and the oblatio ministrormm i.e. the bread and wine brought to the altar by the attendant clergy.

26 According to Polman, 328, Cochlacus had published Canones apostolorum, veterum concilionum constitutiones, decreta pontificum antiquiora, De primatu Romanae ecclesiac (Mainz, 1525). Scc Mansi 1:3013.

${ }^{27} \mathrm{ACA} 24.85-87$ (BS 372).

${ }^{28}$ See CCA 24 (CCath 33:170) and above p. 49.

${ }^{29}$ ACA 24.85 (BS 372).

${ }^{30} \mathrm{Ibid}, 24.66-67$ (BS 368)

${ }^{31}$ Ibid., 24.88 (BS 373). See c.g. Brightman, 373, 377-378, 380.

${ }^{32}$ Occolampadius, Ad Billiboldum Pyrkhaimerum, h2a, "Sunt qui his locis Irenaei, quem non capiunt, supra modun gloriantur: e quibus nuper in connentu Badensi I-Teluetiorum Eccius ct Faber Constantiensis modcstiac suae specimina protulexunt... in quibus asserebantur Corporis Christi in pane pracsentia, \& pro uiuis ac mortuis in Ecclesia sacrificium..." See above p. 35. 
of his anti-Gnostic polemic. The father had been writing against those who denied the goodness of creation and the resurrcction of the body. Oecolampadius believed that it was for this reason Irenaeus and other fathers had referred to the Eucharist as an "offering" of bread and wine.

For it might seem to then a little thing to give thanks with the bread of simple creation and acknowledge the Creator, Giver and Sanctifier, as we understand it to have been the custom among the ancients... For the ancients bore witness to God as the maker of these fruits which they then collected for the use of the poor. It would have been stupid to receive things from some strange and alien god and then to give thanks with them to a good God. ${ }^{33}$

Here Oecolampadius was ambivalent. He felt that such "Christian offerings" were something of a provocation to Christ's death which had put and end to the species of oblationes. ${ }^{34}$ On the other hand, Christ had institutcd the rite of the Eucharist in order that the faithful might give thanks for the benefit of his death. Just as the immolation of victims under the Law had allowed the ancients to testify to their faith in the coming Messiah, so it was expedient now to give thanks, "in bread and wine" for the Redeemer who had come..$^{35}$ In this, as in the sacrifices of the Old Testament, the brcad and wine served as a reminder and representation of an altogether absent benefactor. ${ }^{36}$ Despite the grudging nature of Oecolampadius' commentary on Irenaeus, the way was prepared for the notion of a "significative sacrifice" of bread and wine, "representing" both the anabatic and catabatic movements of the Eucharist, advanced at the Colloquy of Regerssburg in 1541.

\subsubsection{Sacramentum Sacrificii}

In Melanchthon's Apologia, "sacrifice" had an entirely anabatic sense: i.e. it was something offered to God either by Christ (propitiatory sacrifice) or by the reconciled (eucharistic sacrifice). Sacrifices were distinguished from sacraments

${ }^{3}$ Oecolampadius, De genuina verborum hoc est corpus menm, iuxta vetustissine authores expositione liber (Strasbourg: Knobloch, 1525), d5b, "Parum enim eis uideretur pane simplicis creaturae gratias agerc \& creatorcm \& datorem, sanctificatoren agnoscere; quemadmodum ueteribus morem luisse comperimus..."; g $3 \mathrm{~b}$, "Offerebant enim prisci frugibus, deunque frugurn authorem testebastur, quac tamen in usum cedebant pauperum stultum autem fuisset ex alieni $\&$ cuiusdan mali dei rebus, accipere res quibus bono deo gratias ageret." The other father to whom Oecolampadius refers specifically is Ps.-Augustine [i.e. Fulgentius of Ruspe] De fide ad Petrum 18 (PL 40:772) (also included in PL 65:671-705) which refers to the church's unceasing offering of bread and winc.

${ }^{3+}$ Oecolanpadits, De genuina verborum, $\mathrm{d} 5 \mathrm{~b}$.

35 Ibid., d5b-d6a, "Gratias quoque agentibus patribus, immolationibusque legittimas hostias, sufficisbat creditus ille, qui wenturus erat in nomine Domini: \& nobis nunc utilis est gratiarum actio in parie, si ueniße redemptorem testamux. Quoniam pro beneficio mortis gratias agamus debcmus."

${ }^{36}$ Ibicl, d6a. 
which were entirely catabatic: i.e. offered by God to us. This conformed with Luther's distinction between the sacrifices of the law and the promises of the Old Testament. Under the New Testament, God continued to annex signs to his promises, whereas an external sacrificial cult had been entirely abolished.

The symbolic nature of Swiss eucharistic theology made this distinction between sacrifices and promises unnecessary. The Swiss and Southwest German Reformers accepted the traditional claim that the Eucharist, and not merely the death of Christ, had fulfilled and replaced the sacrifices of the Old Testament. ${ }^{37}$ According to Oecolampadius, the sacraments of the New Testament and the sacrifices of the Old belonged to the same category. The only qualitative difference the sacrifices of the Law and the sacraments of the New was that the former prefigured Christ while the latter referred to him in retrospect. As far as Oecolampadius was concerned, both were no mure than figures which made their appeal to faith. ${ }^{38}$

Oecolampadius quoted and examined Chrysostom's florid evocation of the eucharistic liturgy in the "Sermo de Eucharistia in Encaenizs." Admonishing a lax comnaunicant, Chrysostom described the "table of the mysteries." The Lamb was sacrificed, the priest interceded on the people's behalf, the spiritual fire descended on the sacrifice, the Seraphim stood in attendance. ${ }^{39}$ It was clear, Oecolampadius wrote, that there were no real Seraphim, nor any real fire present in the celebration of the Eucharist. Rather, there were deacons and the Holy Spirit. Chrysostom's commentary was thus the salva significatio given to the rite by one who had "lifted up his heart" at the Stursum corda. Why, then, should one pretend that the body and blood were present in the rite if fire and Seraphim were not? ${ }^{30}$ If the body and blood were present, then the Mass would be an attcmpt to repeat Christ's sacrifice. However, just as the bread was called "body" because it was the memorial

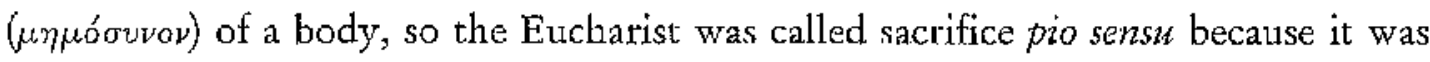
the memorial of a sacrifice. Through it, both body and sacrifice were "represented."

Oecolampadius also referred to another passage from Chrysostom: his Homilia 17 in Hebraeos. ${ }^{41}$ Clark notes the almost universal recourse to this passage

${ }^{37}$ See Kaufmann, 137 on Capito.

${ }^{38}$ Oecolampadius, Ad Billibaldum Pyrkbaimerum, g2b-y2a, "Figurae ueteris legis habent duplicem respectum. Nam uel respiciunt Christun ipsum qui est impletio \& finis legis, ac ligurarum omnium... uel respiciunt ceremonias nouae legis, utpote Baptismum, uel caenam Dominicam, \& sic pares censendae: neque est discrimen aliud, cuam quod illac praccodunt, nostrae sequuntur. Dignitas autem earum erit fide, illis probe titentium..."

${ }^{39}$ Ibid., D3a. Chrysostom's sermon is entitled, De poenitentia... itemque de sacra mensa et de indicio bominis in PG 49:345. Its authenticity is discussed in PG 64:491 apparently without any awareness that it appears elsewhere under another title.

${ }^{40}$ Ibid., Dảb.

${ }^{41}$ Ibid, F8b. 
among Catholic apologists of the period. As we have already noted, the same passage (attributed to "Ambrose") appeared in Lombard's commentary on the una oblatio of Hebrews. Lepin describes it as one of the four fundamental texts underlying mediaeval writing on the Mass between the 9 th and 12 th centuries. ${ }^{42}$ What neither acknowledges, however, was that the passage was equally popular with Zwingli, Oecolampadius and (as we shall see) Bucer. Because of its subsequent importance to Bucer and its importance as a whole, it is worth quoting here in full:

$\mathrm{He}$ [i.e. Christ] is therefore the sacrifice and priest and victim, for if this were not so, it would be the case that many sacrifices were offered and that he were crucified frequently... So what do we do? Surely we offer every day. Indeed we do offer, but by performing the memorial of his cleath. And the victim is one, not many. How is he one and not many? Because he has been offered "once," and has been offered in the "holy of holies." For this sacrifice of ours is a likeness of his. We offer the very same one every time. We do not offer a different one today, and another tomorrow, but always the same one. Thus there is one sacrifice... For our high-priest is the onc who offered the victim which purifies us, and we offer now what was offered then and can never be consumed. However, what we do now is done in commemoration of what was done. Hor he said, "do this in memory of me."

Zwingli (who appears to have been less happy about this passage than Oecolampadius) claimed that Chrysostom had almost been forced to changc his nind when he saw the semel of Hebrews 9:26. However, the father had concluded that the Eucharist could legitimately be called a sacrifice because what was done in the Eucharist was done as a memorial of what Christ had done. ${ }^{44}$ Here Zwingli

${ }^{42}$ Lepin, 37. The transmission of the text to its inclusion in Lombard, Sententiate 4 d.12 a.6 (PL 192:866) and Decretum Gratiani 3 de consecr. dist.2 c.53 (Friedberg 1:1333) is traced ibid., 43; See also Clark, $93 \hat{f}$.

41 "Ipse ergo et sacrificium et sacetdos et hostia; si cnim hoc non esset, multa etiam oportebat sacrificia olferri, sacpius oportebat crucifigi... \{Quid ergo nose Nonne per singulos dies offerimus? Offerimus equidcm, sed ad recordationen facientes mortis cius. Et una est haec hostia, non multae. Quomodo una est et non multae? Et quia semel oblata est illa, oblata est in sancta sanctorum. Hoc autern sacrificium exemplar est illius; idipsum semper offerimus, nec nunc quidem alium, crastina alium, sed semper idipsum: proinde unum est hoc sacrificium... (Pontifex autem noster ille cst, qui hostian mundantem nos obtulit; ipsam offerimus et nunc, quae tunc oblata quidem consumi non potest. Hoc autem, quod nos facimus, in commemorationem quidern fit cius, quod factum cst: 'hoc enim facite,' inquit, 'in mearn commenorationem. '\} Non alitd sacrificium sicut pontifex, sed idipsum semper facimus, magis autem sacrificii recordationem operamus." Translation by Bernard Brixianus in Divi Loannis Chrysostomi opera, 5 v., (Paris: Clauds Chevallon, 1536), 4:323CD; First ptablished in Erasmus' 1517 Basel ed. of Chrysostom's Opera. Text in brackets represcrits the excerpt in Decretum Gratiani (Friedburg 1:1333) and other mediaeval sources. Accordirg to Lepin, 42, n. 2, the translation in the Decretum was the work of Mutianus (6th cent.). See PG 63:349. Greek, ibid., 130-131.

${ }^{+4}$ Zwingli, Auslegen, 18 (CR 89:152); De canone (CR 89:586). Cf. Occolampadius De gentina verborum, c4b-c4a, "Declarat autem seipsum, quid sacrificium et oblationem dicat, nempe nihil aliud, quam recordationem oblationis. Et sicut sacrificium se habet, ita et corpus. Vnde hic est 
compared the language of "sacrifice" with the way it might be said at Easter that, "today Christ our Lord is risen from the dead." This was not, he wrote, because Christ had risen in the listeners' homes on that very day, but because Easter Sunday was called the "Day of the Lord's Resurrection." In De canone missae epicheiresis, Zwingli added that this figure of speech was used because it rendered the memory more vivid. ${ }^{45}$

In his Apoluyia Melanchthon was anxious to dissociate the Wittenberg Reformation from the notion that the Eucharist was a mere commemoration. The Supper, he wrote, was not the "idle celebration of a show" like a tragedy written in memory of Hercules or Ulysses. To remember the benefits of Christ, was to receive them in faith and to be brought to life through them. Thus renission of sins and new life were applied to those who received the sacrament." In the Augsburg confession Melanchthon appealed to Ambrose's, "because I am always sinning, I must always take medicine for it." 47 Catholic apologists had used this passage in support of their contention that the Mass must be offered every day for sins. ${ }^{48}$ However, as we have already seen, this passage had also been used by early mediaeval commentators to denuonstrate that the representation or immolation of Christ's sacrifice occured "most distinctly" in communion when the blood of Christ was poured into the mouths of the faithful. ${ }^{49}$ Thus, within the Lutheran tradition, the Lord's Supper could be "representative" in a strong sense when the faithful applied its benefits to themselves, through faith, in the reception of communion. Again, the way was prepared for the language of "representative sacrifice" used in the Worms-Regensburg Book.

\subsubsection{The Application of the Mass}

On the subject of prayer for the dead, Zwingli declared himself amazcd at his opponents' appeal to the claim of Augustine and Chrysostom that this practice

recordario corporis, quae ipsum corpus dicitur. Distinguit autem inter oblationem quae semel facta, $\&$ quotidianan. Nam illa est unica, \& in Sancta sanctorum illata. Oblatio autern quotidiana est Hiuóovruv."

${ }^{45}$ Zwingli, Auslegen 18 (CR 89:151); De canone (CR 89:587). Zwingli appcars to be indebted for this idea to Augustine, Fpistola 98 "ad Bonifacium" (PL 33:363) where it appears in a discussion of Baptism. See Lepin, 39.

46 ACA. 24.72 (BS 370), "Meminisse Christum non est otiosa spectnculi celebratio, aut exempli causa instituta, sicut in tragoediis celebratur memoria Herculis aut Ulyssis; sed est meminisse beneficia Christi, eaque fide accipere, ut per ea vivificcmur..."

${ }^{47}$ CA 24.30 (BS 94), "Nam id est meminisse ac sentire quod yere cxlibeantur nobis. Nec satis est historiam recordari, quia hanc etiam Iudaet et impii recordari possunt. Est igitur ad hoc facienda missa, ut ibi porrigatur sacramentum his, quibus opus est consolatione, sicut Ambrosius ait: Quia semper pecco, semper debeo accipere medicinam." Cf. De sacramentis 4.6 (PL 16:464).

${ }^{+8}$ e.g. Eck, De sacrificio 1.10 (CCath 36:60).

${ }^{49}$ See above p. 41. 
came from the apostics. He wrote that could find no mention of this in the writing of these fathers. This suggests that Zwingli had not read Biel's Sacri canonis missate expositio where at least Augustine's opinion had becn noted. ${ }^{50}$ Z wingli wrote that even if it was the case that the practice came from the apostles he could only imagine that they had recommended it as a concession the weaker brethren. ${ }^{51}$ The same must have been the case with the language of merit associated with the intercession of the saints. Prayers to the saints who had died had no warrant in Scripture and militated against the mercy of God. Nevertheless, mutual prayer among the saints on earth clearly had Scriptural warrant. There was also a Scriptural language of "reward" promiscd to good works, but it had to be understood that these works were performed by Christ in us and that he alone could truly be said to "merit" anything. In his reply to Emser's Canonis missae defensio, Zwingli concluded that wherever the language of "reward" appeared in Scripture, it was again an accommodation to the weak who were still in need of such "milk." (cl. 1 Cor 3:2.). ${ }^{52}$

As we have already noted, the "Greek Canon" featured prominently in the discussion of eucharistic sacrifice in Melanchthon's Apologia. Melanchthon recognised that, like the Roman Canon, the Greels one included a memorial of the dead. "We do not disapprove of this," he wrote, "but we do disapprove of the application of the Lord's Supper to the dead ex opere operato." ${ }^{53}$ 'The fourth-century heresiologist Epiphanius had condemned the followers of an Aerius who denied the expedience of prayer for the dead. Melanchthon noted, however, that Epiphanius had not condemned those who denied that the Mass could be applied to them ex opere operato. Hence the Reformers could not be condemned as "Aerians." ${ }^{54}$ Melanchthon argued that to "offer" for the dead in the contcxt of the Eucharist was in fact to offer thanksgiving for them. He noted that the Liturgy of John

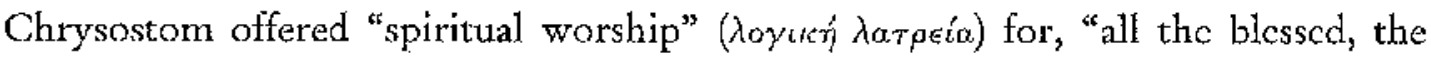
patriarchs, prophets and apostles equally." There was, in other words, no distinction made between offering for the faithful departed and offering in memory

${ }^{59}$ Biel, Expositio $56 \mathrm{H}$ (Oberman \& Courtenay 3:374m375).

${ }^{51}$ Zwingli, De canone (CR 89:595-596).

j2 Zwingli, Adversus Emserum (CR 90:280).

${ }^{53}$ ACA 24.94 (BS 375), "... Hos non improbamus [i.c. oratio pro mortuis] sed applicationem coenae Domini pro mortuis ex opere operato improbamus." Cf. Luther, Sermon von dem neuten Testament (W A 6:372).

${ }^{54}$ ACA 24.96-97 (BS 376). Cf. CCA 24 (CCath 33:162) 8x Fipiphanius, Contra baereses 3.1 (heresy 74) (PG 42:503-516). According to PG 41:iv, Mclanchthon possessed an nns. of Epiphanius, Panutrion (i.e. Contra bacreses). 
of saints in glory. ${ }^{55}$

Unlike Zwingli, Melanchthon allowed that the saints and angels in glory intercede with God for the church. He also allowed that they might be honoured in a threefold manner. Firstly, the church should give God thanks for the mercy he had shown the saints and for his gifts which they had faithfully used for the good of the church. Secondly, the saints' memorial should strengthen the faithful who saw how grace had triumphed in them. Thirdly, each of the faithful should imitate them in faith and in the virtues proper to his or her vocation. ${ }^{56}$ It did not follow from any of this, however, that the saints were to be invoked by name, and Melanchithon pointed out that the Roman rite, even on the feast-days of the saints, never "invoked" them. Rather, the Canon and all the collccts of the Mass were addressed through Christ to God the Father. ${ }^{57}$

He objected, however, to the false belief that the merits of the saints could be applied to others through the Mass. As evidence that such a belief existed, he citcd a passage in Biel's Sacri canonis missae expositio which claimed that the faithful could be "saved" through the merits and prayers of the saints. ${ }^{58}$ Like Zwingli, Melanchthon accorded a qualified legitimacy to the language of merit itself. Eternal life was not owed to the good works of the justified, but it was the reward promised them. In the present life it also pleased God to bestow bodily and spiritual rewards upon works done in faith. ${ }^{59}$ Each, however, received according to his or her own work (1 Cor 3:8) and one person's merits could not be mediated or applied to another.$^{60}$ Unlike Melanchthon and Zwingli, Bucer would find a way of admitting the Canon's refcrences to the assistance of the saints' merits and prayers. In other words, he would, find a sense in which they could be described as "applicable."

\subsubsection{The Private Mass}

As we shall see, Eck did not write a defence of the private Mass until 1541. Early Catholic apologetic seetns to have considered the private Mass defended as long as the sacrificial nature of the Mass was asserted. It was only when doubts were cast on the desirablility of the practice from within the Catholic camp that Eck was

55 ACA 24.93 (BS 37.5) "... applicat cam [i.e. logike latreia] pariter beatis omnibus, patriarchis, prophetis, apostolis. Apparet igitur, Graecos tamquam gratiarum actionem offerte." (Brightman, 387-388)

56 ACA 21.4-7 (BS 317-318). Cf. Zwingli, Auslegen (CR 89:166-222).

${ }^{57}$ ACA 21.10, 13 (BS 318-319).

${ }^{58}$ ACA 24.23 (BS 321). Cl. Biel, Expositio 30N (Oberman \& Courtenay 1:312), "Ex quibus patet, preces nostras spemque conscquendae beatitudinis per mediatores sanctos in caelo inanes non esse, sed ordinc a Deo instituto nos ad corum auxilia confugere debere ac debita veneratione eos semper implorare, ut salvemur eorum meritis atque votis" \& Canonis missae, Communicantes.

${ }^{59} \mathrm{ACA} 4.354$ (BS 227).

${ }^{60}$ Ibid., 21.29 (BS 322). 
moved to defend it. ${ }^{6 t}$

In the Augsburg confession and in the Apologia, Melanchthon claimed that the private Mass (as opposed to the frequent celebration of Mass with communicants) was a novelty which had crept into the church at the time of Gregory the Great (i.e. late in the sixth century). ${ }^{62}$ In the Augsburg confession, Melanchthon noted that, according to the Historia tripartita, there had been a daily Mass in many churches. However, since Chrysostom referred to the priest standing daily at the altar bidding some come to communion and warning others away, he concluded that this celebration had involved daily communion as well. $\mathrm{He}$ cited the "ancient canons" to the same end. ${ }^{63}$ In the Apologia, Melanchthon cited Epiphanius' claim that the church of Asia had received the practice of thrice-weekly communion from the apostles. ${ }^{64}$ He also noted that the Greek church celebrated the Eucharist on Sundays and feast-days only, while in Eastern monasteries a single public Mass was celebrated daily. He attributed the rise in popularity of the private Mass to the arrival of the venal mendicant orders, but remarked that cven Francis of Assisi had exhorted his brethren to celebrate a single communal Mass each day. ${ }^{65}$

\subsubsection{The Canon}

For Zwingli, the Canon was one among many examples of the way in which "neglect of the Word of God has given the fathers occasion to err." congeries: i.e. an accumulation of the work of various writers which took its final form after the time of Gregory the Great. ${ }^{67}$ If it had been considered a "canon" at the time of Gregory, Zwingli argued, this pope would not have dared to change it. Such was the barbarity and coarseness of the Latin in the present Canon that a man such as Gregory would either have rejected it cntircly and started alresh, or he

6: See below, ch. 8, p. 162.

62 CA 24.35 (BS 25); ACA 24.7 (BS 351). He does not cite his sources. See, however, Gregory, Epistolae 2, 97, 150 (PI. 77:548, 660, 834). Luther also accuses Gregory in De abroganda (WA 8:452-453,449).

${ }^{63}$ CA 24.34-41 (BS 94-95). See Historia tripartita 9.38 (PL 69:1155D); Chrysostom, Homilia 3 in Enistolam ad Epherios 1. (PG 62:29); Council of Nicea 1, can.18 (Melanchthon seems to be referring to can.18 "De clericis usuram aut ampliationem accipientes" in the Ps.-Isidorean Decretals (PL84:97; Mansi 2:691) rather than the can. 18 which appears in Mansi 2:676 \& 690. Old, 24 records a 1524 edition: Tomus primus quatuor conciliorum generalium... Ysidoro authore, ed. J. Merlin (Paris, 1524)) 830).

${ }^{64}$ ACA 24.8 (BS 351). Cf Epiphanins, Contra baereses 3.2.expositio fidei 22 (PG 42:825-

${ }_{65} \mathrm{ACA} 24.6-8$ (BS 350-351). See Francis of Assisi, Epistold toli ondini misa una cum oratione: Omnipotens aterne in Francois d'Assise: ÉErits, ed Desbonnects (Sources chrćticnnes, 285) (Paris, 1981), 250, "Moneo propterea et exhortor in Domino ut in locis, in quibus fratres morantur una tantum missa celebreturr in die."

${ }^{66}$ Zwingli, De canone (CR 89:586).

${ }^{67}$ Ibid., 564 . 
would have left the prayer absolutely unchanged precisely becatise of its status as "Canon." As we have already remarked, Zwingli questioned the authenticity of Ambrose, De sacramentis, and thus discounted the possibility of at least the fifth century origin of a substantial portion of the Canon. ${ }^{69}$ Even if De sacramentis were the work of Ambrose, Zwingli, argued, the father had left it to other bishops to alter the prayer as they saw fit. Zwingli would follow his example. ${ }^{70}$

\subsection{Summary: Eucharistic Sacrifice and Tradition in the Early Reformation}

A number of commentators have noted that as a consequence of Catholic insistence on the inspired nature of Tradition, the caltegories of "father" and "council" bccamc historically elastic. Theoretically, as much reverence was due to the teaching of Bernard and Thomas as that of Augustine and Jerome; to Iateran IV and Constance as to Nicaea. Because they could not privilege a certain cra of the church's history, the apologists tended to minimise (or simply overlook) any differences between ancient and contemporary Christianity. ${ }^{71}$ In this early period, we find no sense of doctrinal development and no acknowledgement of an Erasmian hierarchy of doctrines and practices with some categorised as essential and others as less essential. For example, in answer to Luther's claim that Massvestments were a matter of indifference, Emser wrote:

after instruction for those priestly vestments had been given under the Old Law by God himself, and was then received by the church through the tcaching of the Holy Spirit, the holy canons prohibited the celebration of Mass without them. Thus I do not think that anyone is free to omit them without sinning... for "the one who does not listen to the church" (as Christ says) "is to be to you as a pagan or a tax-collector.".72

The passage suggests the largely defensive character of much Catholic writing on eucharistic sacrifice in the decade between 1520 and 1530. The response to Protestant insistence on the primacy of Scripture, was to emphasise the stablc and uniformly authoritative witness of Tradition (including the traditional exegesis of Scripture). Granted such accidental changes as James' commitment of the Mass to

${ }^{68} \mathrm{Ibid} ., 565$ \& 569 , "Barbarismos ac soloecismos ad hunc usum indicabo, ut, quibus rudius csl iudicium, paulatinn videant non apud priscos natum esse canonem, apud quos eloquentiae artificiuns longe integrits erat."

${ }^{69}$ Tbid., 567.

${ }^{70}$ Thid,., 567.

317.

${ }^{71}$ R. Kecn, 708; Sec also Bagchi, 166; Fraenkel, Testimonia, 258f; 'I'avard, 129; Polman, 316-

${ }^{72}$ Emser, Missae assertio (CCath 28:34). 
writing, and the additions made by warious popes; granted even the differences between the Eastern and Western liturgies, the Mass remained substantially the same as that first offered by Christ in the Supper. Tertullian understood the "offering" of Christians in the same way as Paul. Chrysostom and Aquinas understood the "offering" of Christians in the same way as Tertullian.

Protestant insistence on the prinacy and normative character of Scriptural authority did not imply an indifference toward Tradition. The witness of Tradition assured Zwingli and Melanchthon that their interpretation of Scripture was no innovation. Rather, it was the re-assertion of the primum et verum obscured by the papal church. The testimony of the fathers assured Melanchthon of the church's preservation in the truth. The preserved church, however, was not the one identified with institutions such as the papacy or councils, but the one which had listened to and preached the Word across the course of history. This "dcpatentification" of the fathers freed the Reformers from the obligation to appropriate the Tradition wholesale, and allowed them to draw attention to its differentiated nature. They could argue that when Tertulliarı or Irenaeus spoke of sacrifice in the context of the Lord's Supper, they had not meant a propitiatory sacrifice availing ex opere operato. Rather, they had meant thanksgiving, praise and prayer. Zwingli characterised the Roman Canonl as an example of neglectio verbi Dei. Nevertheless, Luther, Melanchthon and Oecolampadius made some attempt to identify the historical circumstances out of which such vocabulary had arisen. Alt three linked it with a collection of bread, wine and alms in the context of the Supper. Oecolampadius added to this the need to asscrt the goodness of creation and the Creator, by "offering him" gifts of bread and wine.

Dcspitc the diametric opposition which Luther saw between the Catholic and Evangelical accounts of the Lord's Supper, it should be evident from the discussion above that there were points at which the various accounts began to convcrgc. All agreed that the memorial of the Supper "represented" the sacrifice of Christ on Calvary. For both the Lutherans and the Catholics, the representative function of the consecration and communion was "strong": i.e. it had an objective cfficacy. According to both the Lutheran and Catholic accounts, Christ continued as the principal agent when this institution was observed by the church. The church's minister, in other words, acted on Christ's behalf in the administration of the sacrament. Despite the Scotist-Nominalist claim that the sacraments were effective ex opere operato in the absence of any obstacle (obex) to grace, the Catholic apologists insisted that faith was necessary in order to enjoy the fruits of the Mass. Melanchthon conceded that the memorial of Christ's death was an appropriate context for the offering of thanksgiving and intercession for oneself and others, 
including the dead.

These points of convergence form the basis of the common statements on the Mass which would emerge from the colloquies in the following decade. Much of the intellectual impetus for these colloquies would come from the Humanist theologians who wrote from both sides of the Reformation divide. Their approach to the eucharistic sacrifice will be considered in Chapter Seven. I-Towever, I propose now to turn to Bucer and examine his attitude toward the sacrifice of the Mass in the early part of his career. 


\section{BUCER'S EARLY WRITING ON THE MASS: 1523-1531.}

\subsection{Introduction}

\subsubsection{The Abolition of the Mass in Strasbourg}

...often I celebrated Mass and read the Canon, and my intention in doing so was equally devout, but at the time, I could not assess the meaning of the words, "these offerings," "the gifts," and similar expressions found in the Canon. Thus I recited them and did not even know why, and though I was willing to explain and interpret them for someone else in accordance with the meaning given then by papal teachers, yet my mind and heart could not appreciate or grasp them in the way in which they were presented.'

This reminiscence appears in Bucer's Kurtzer wabrhaffiger Bericht, published in 1524. At this point, Bucer's memories of his own celebration of the Mass as a Dominican priest must have becn relatively fresh. He had been ordained in Mainz in 1516 at the age of 25 . He was released from his vows as a Dominican in March or April 1521, but served as a court chaplain to the Count-Palatine Frederick. From May to October 1522 he served as priest in Landstuhl, and from November 1522 to April 1523 as preacher in the church of Saint John at Wissembourg. His first attack on the Mass appeared in the Summary (1523) of his preaching before the towncouncil and people there.

Bucer offered the above reflection on his earlier understanding of the Mass by way of an excuse for those fathers who had permitted various practices into the worship of the church without realising that they were incompatible with Scripture. They had, Bucer thought, acted unreflectingly - just as he had when celebrating the Mass. ${ }^{2}$ God's Word clearly forbade anyone to offer sacrifice in a manner other than that commanded by God. In seeking to make a sacrifice of the Mass, the fathers had erred, just as disciples of Christ - even the apostles - had erred since the foundation of the church. ${ }^{3}$ For Bucer, as for Luther, Zwingli and the other Reformers, any argument about eucharistic sacrifice was inextricably bound up with an argument about the nature of the church's history and its tradition.

It is difficult to reconstruct what understanding of the eucharistic sacrifice Bucer had inherited from his theological education. Cajetan's Opuscula aurea, (the work in which Cajetan had worked out his ideas about the value of the offering of

\footnotetext{
${ }^{1}$ Ein kurtzer wabrafftiger Bericht (1524) (BDS 2:106).

${ }^{2}$ Ibid.

${ }^{3}$ Ibid., 105.
} 
the Mass) was included among selected "philosophical" works at the end of the book-list which Bucer sent from Heidclberg to the Dominican prior at Selestat in 1518." However, in 1529 he would mention the "horrid imposture" that "the Mass is such that, whatever the condition of the one who celebrates it, its merit is nevertheless infinite and efficacious in obtaining anything from God." ${ }^{\text {" Augustijn }}$ describes this remark as "popular belicf." However, if qualifications were made about the devotion of the celebrant and beneficiaries, this would be a fair representation of Cajetan's "Thomism." Yet this was the first time that this particular "imposture" had appeared in Bucer's writing, and he seens to have mentioned it with the air of one discovering a novelty. On the other hand, in his Summary, Bucer noted the argument that the effectiveness of the Mass was not dependent on the moral condition of the priest because the priest offered on behaif of the whole Christian assembly: i.e. the "merit" was the fluctuating but never entirely absent holiness of the church. ${ }^{8}$ "This is closcr to Iscrioh's "Scotism," but as Iserloh himself observes, theology of eucharistic sacrifice on the eve of the Reformation was cclectic, and the Thomist view was a minority one. ${ }^{9}$ If the remarks quoted above are anything to go by, Bucer's education on the Mass had produced mostly puzzlement.

On the other hand, Bucer's list for the Prior of Selestat included Erasmus's Encbiridion militis christiani (1515). The list described this as a "theological work." In it Erasmus alluded to the sacrifice of the Mass in the middle of a discussion of two passages from the Gospel of Johnn chapters 3:24 on worship in spirit and truth and 6:63: caro non prodest quiquan. In his discussion, Erasmus contrasted the celcbration of the Mass according to the flesh with its celebration according to the spirit:

Perhaps you sacrifice [i.e. offer Mass], and live for yourself, and the misfortunes of your neighbour do not touch you. You are still in the flesh of the sacrament. If, however, as you sacrifice you give effect to what your participation signifies - that is, to be of the same spirit as the Spirit of Christ, the same body as the Body of Christ, a living member of the Church - if you love nothing except in Christ, if you

\footnotetext{
${ }^{4} \mathrm{BCor} 1: 48$.

${ }^{5}$ Epistola Apologetica (BOL 1:107-108).

${ }^{6}$ Ibid., 107, n. 131.

${ }^{7}$ Iserloh, "Der Wert der Messe," 71.

${ }^{8}$ BDS 1:122, "Es gylt auch nichs... ob schon der pfaff boeß sey, so scy dic Mesß dennest gitot und das gebett auch krefftig, dann es gescheh in person gemeyner christlichen versammlung." I.uther discusses the case of the bad priest offering ex opere operato in Sermon von dem nexen Testament (WA 6:371, 10-12), but not in the context of the bad priest offering ex persona ecclesiae.

"Iserloh, "Wert," 65.

${ }^{16} \mathrm{BCor} 1: 45$.
} 
consider all your goods to be held in common with everyone, if the misfortunes of all grieve you exactly as if they were your own, then you sacrifice with great fruit, for you sacrifice spiritually. If you feel yoursclf somehow transfigured into Christ, and living less and less in yourself, give thanks to the Spirit who alone gives life... let what is represented beforc your eyes there be carried out in you. It is the death of your Head which is represented. Examine yourself inwardly in your heart to see how close you are to being dead to the world. Because if anger, ambition, greed, self-indulgence still possess you cntircly, even if you partake of the altar, you are far from the worship. Christ has been killed for you; slaughter those victims of your own. Sacrifice yourself to him; who sacrificed himself for you." "1

I have quoted this passage in full, because it seems to me to capture both the essence of the critique of the Mass adopted by Bucer as well as his cautious reappropriation of the vocabulary of eucharistic sacrifice at the end of the 1520 s and thereafter. Although Bucer would reiterate Reformation common-places such as the semel of Hebrews 9:12, he would judge the Mass and the liturgical reforms at Strasboutg as much by the criteria of love of neighbour and communion of the faithful among themselves and with Christ. Where he thought that these could be secured, he would consider readmitting the eucharistic-sacrificial vocabulary of the fathers. Moreover, for a brief period in the following decade he would consider the readmission of the traditional eucharistic rite.

Bucer arrived in Strasbourg in May 1523 and was involved with the first changes to the celebration of the Mass in Strasbourg at the end of the same year. On 3rd December he officiated at the marriage of Mathias Zell, Public Preacher at the Cathedral, and Katharina Schutz. During the nuptial Mass, Zell and his wife received communion under both kinds. On 27th Jantary 1524, Zell administered the rite of Baptism in German. This paved the way for the celebration of a modified "German Mass" with the administration of communion under both kinds in the Cathedral chapel of Saint John on 16th February. ${ }^{12}$ In the course of 1524 and in early 1525, the Strasbourg presses produced a number of Evangelical orders for the celebration of the Mass. ${ }^{13}$ These were ritually conservative. ${ }^{14}$ The elevation of the host was retained, as were the priestly gestures and genuflections. The rite retained the name "Mass." Its celebrant continued to face the altar and was described as a

11 Erasmus, Enchiridion militis christitni (LB 5:30F-31AB).

${ }^{12}$ Bornert, La réforme protestante du culte à Strasbotirg aut xut siècle (1523-1598): approche sociologique el interprétation ribéologique (Leiden, 1981). 110-118, 143; M. Lieshard, "Introduction," in BOL 1:3. The celebrant was probably Diebold Schwarz, Zell's assistant at the parish of St Lawrence.

:3 Bornert, 113-118.

is See BCor 1:293. 
"priest." The offertory prayers of the minor canon were replaced in the Tettsche Messe by Diebold Schwartz with a version of the Orate fratres. This exhorted the congregation to pray to the Father through the Son for the gift of the Spirit in order that they might become a living, well-pleasing sacrifice. ${ }^{15}$ In all of the orders the Canon was either modified or replaced entircly. ${ }^{16}$ The prayer which followed the elevation in the order, Teutsch Kircben Ampt (1525) seems to have been an attempt to adapt the Canon's post-consecratory prayers to the interpretation of eucharistic sacrifice outlined in Luther's Sermon von dem Neuen 'I'estament. Christ: was described as our, "high-priest," "himself the sacrifice and atonement for our sins." The prayer declared the resolve of the faithful to take up the cross of their own suffering and to follow their Lord in the path he had already trod. In Schwartz's Mass, however, the post elevationem simply described the body and blood of Christ as an assurance and promise through which believers were made certain of grace won through Christ's passion and death. ${ }^{17}$ These German "Masses" were a short-lived phenomenon. Even as they emerged from the printing houses of Strasbourg, more radical reform of the eucharistic liturgy was under way.

Even before this, however, Catholic opposition to Luther's views had been evident in Strasbourg. In 1520, the Franciscan Thomas Murner (1469-1537) had published the relatively irenic Cbristenlicbe und briederliche ermanung ir reply to Sermon von dem neuen Testament. ${ }^{18}$ Between 1520 and the end of 1522, Murner launched a series of progressively angrier pamphlets against Luther and his views culminating in Von dem grossen Lutherischen Narren (Dec. 1522). ${ }^{19}$ At around the same time, Murner translated Henry VIII's Assertio septem sacramentorum. This was published in 1522, and again 1523, by the Catholic printer Johann Grüninger. Grüninger also published Emser's Missae clbristianorum assertio and a German translation of extracts from Fisher's Assertionis Lutheranae confutatio - both in $1524 .{ }^{20}$

From the end of May 1524 Murner delivered a series of six sermons on 1

${ }^{15}$ The text of this prayer is quoted in Old, $19, \mathrm{n}, 5$. See also the description of the Ritus caende dominicae, quem obseruamus in Bucer's and Capito's letter to Zwingli, mid-11.1525, (BCor 1:285) and in their letter to Luther, 23.11.1524 (BCor 1:293).

16 The text of the eucharistic prayer from Schwarz's ms. together with major variants from the other Strasbourg German Masses of 1524 can be found in Coena Domini: die Abendmablsiturgie der Reformationskircben im 16./17. Jahrbundent, Pahl, ed. (Freiburg, 1983) 1:311-317.

${ }^{17}$ Ibid., 314-315.

${ }^{18}$ Iserloh, Der Kanpf um die Messe in den ersien Jabren der Auseinandersetzang nil Lutber, (Münster, 1952),13-19.

${ }^{19}$ Lienhard, "Thornas Murner et la Relormation," chap, in Un temps, wne ville, ane Réforme: la Reformation à Strasbourg: Studien zur Reformation in Strassburg (Aldershot: Variorum, 1990), $51 f f$. Sce also bibliography in Thomas Mumer: Elsäsischer Thenloge und Humanist, 1475-1537, ed. Badischen Landesbibliotlek Karlsruhe (Karlsruhe, 1987), 186-196.

${ }^{20}$ Lienhard, "Introduction," BOL 1:5-7. 
Corinthians 11 (i.c. on the Eucharist) at the Franciscan convent in Strasbourg. The series was well-attended, as was the preaching delivered concurrently in the same convent by three of the Evangelical clergy: Wolfgang Capito, François Lambert and Bucer. Murner expressed dismay that such matters should be debated before the laity, and this dismay seems not to have been entirely unjustified. 'The crowds in attendance were disorderly, and Murner's physical safety was endangered on at least one occasion. The Rat (Senate) sought to restore order by stipulating that such preaching was henceforth to be delivered only in Latin. ${ }^{21}$ Though the Evangelical preachers challenged Murner to a formal public disputation, he demurred. Eventually he was lured to a congressus amicus with the Reformers. At this meeting he argued that because the preachers had challenged him, they should undertakc to answer his arguments rather than he theirs. Murner was finally prevailed upon to hand Bucer a copy of his sermons (these have not survived). ${ }^{22}$ Bucer replied in writing with De caena dominica which was published late in the summer of 1524. The sacrificial nature of the Mass - i.e. what Murner had undertaken to demonstrate - was considered in the work, but Bucer also dealt with other matters raised in Luther's De captivitate Babylonica, Sermon von dem netun Testament and Von Anbeten des Sacraments (i.e. transubstantiation, the testamentary nature of the sacrament, and the veneration of the host).

We began this chaptcr with Bucer's remarks on the Mass in Kurtzer weabrbafftiger Bericht against Conrad Treger (c. 1480-1542) the head of the Rhineland-Swabian province of the Augustinian conventuals. This work, too, was an attempt to publicise the results of another public disputation manquée. ${ }^{23}$ In March 1524, Treger had published a hundred theses on the authority of the church (Paradoxa centum...de ecclesie concilorumque auctoritate) in his native Freiburg, and professed himself ready to defend these. The Strasbourg preachers wrote to Tregcr in the same month accepting his challenge to a disputation. They promised that this would take place in front of a select audience and assured him of security in Strasbourg. ${ }^{24}$ Treger stalled, in the meanwhile engaging in a pamphlet skirmish with Capito. Eventually he was persuaded to come to Strasbourg and to enter a Latin disputation with Capito, Bucer and Lambert. ${ }^{25}$ 'I'reger's presence in the city

\footnotetext{
${ }^{21}$ For the structure of the Strashourg magistracy see Chrisman, Strasbourg and the Reform: a Study in the Process of Change, (Now Haven, 1967), 24-27.

${ }^{22}$ Sec Bucsr's account in BOL 1:21, and in a letter to Capito, late July/early Aug 1524 (BCor 1:262-263, no. 70).

${ }^{23}$ For the following account, see introduction by J. Müller in BDS 2:17-33.

${ }^{24}$ BCor 1:222-226, no. 61-62.

${ }_{25}$ There is a brief account of this disputation at the beginning of the Kuivzer reabrbaffiger Bericht (BDS 2:39-40). Regarding the exchange between Treger and Capito see BCor 1:264-265 and BDS 2:23ff. See also Millet, Correspondance de Wolfgang Capiton (147-1541): analyse et index (daprès le Thesaurus Baumiants et autres sources) (Strasbourg, 1982), no. 221, 223, 228.
} 
attracted hostile attention. He was held to have slandered the Rat and people of Strasbourg by accusing them of heresy in a Schmachbuchlein addressed to Capito. Following the disputation, Treger was placed under house-arrest. $\mathrm{He}$ was released after he had persuaded the Rat that he had not wished to defame them, and he returncd to Switzerland refusing further challenges to disputation. The Kurtzer wabrbafftiger Bericht, published in October 1524, contained Bucer's account of the events connected with Treger's visit to Strasbourg. It also contained his answer to Treger's Paradoxa. It dealt with the Mass as an example of the fundamental question at issue in the debate: the relationship between the teaching authority and institutions of the church and the authority of Scripture.

At the end of December 1524, Bucer published, Grand und Ursach. Although the German Masses were still emerging from the printing houses in 1525, the Strasbourg preachers were beginning to push for more radical changes in the liturgy. The elevation of the host, the priestly vestments and the use of a stone altar had been abolished along with a host of other traditional liturgical practices before the end of $1524 .{ }^{26}$ Writing to 'Zwingli in November 1524, Capito and Bucer noted that, on account of the "wcakncss of ccrtain peoplc," they had so far tolerated ceremonies which were not of themselves contrary to the Word of God. Now, however, the time had come to do away with these practices of a "bygone age."27 Grund und Ursack was both a defence of changes which had already taken place and a progxamme for further liturgical reform. Though written by Bucer, it was also signed by the clergy of the six city parishes. Henceforth, they asserted, the church in Strasbourg would use only those prayers and words which were drawn from Divine Scripture. God had commanded his people to add nothing to his law and to take nothing from it (Deut 12:32) ${ }^{28}$ This principle was to be applied with particular rigour to the Mass:

For since light has nothing in common with darkness, Christ no relationship with Belial and the believer no share with the unbeliever... we have, on the basis of Scripture, completely abolished and suppressed everything in our community which was added to the Lord's Supper to strengthen and embellish the contempt and mockery of Christ and of divine mercy. "I'hus we no more use the name "Mass," rather, "the Lord's Supper." 29

A discussion of the sacrifice of the Mass, the eucharistic memorial, the elevation, the vestments and ritual gestures occupied over half of Grund und Ursach.

\footnotetext{
${ }^{26}$ Bornert, 96-97.

${ }^{27}$ BCor 1:281-286. See also their letter to Luther, 23.11 .1524 (ibid,, 288-289).

${ }^{2.6}$ BDS 1:207.

${ }^{29}$ Ibid., 206.
} 
Only at the end of the discussion of the Lord's Supper do we find intimations of the sacramental controversy which was about to consume the Evangelical movement and elbow eucharistic sacrifice to the periphery of the Reformers' attention. ${ }^{30}$

Despite this radical programme of liturgical reform, the celebration of the Mass was not finally abolished in Strasbourg until February 20 th 1529 after a vote in the assembly of the Scboffen. ${ }^{31}$ From 1526 , the Rat had received petitions seeking the final abolition of the, "four horrible, idolattous and blasphemous Masses" which continued to be celebrated in the chapters of the Cathedral, St. Thomas', Old Saint Peter's and Young Saint Peter's. ${ }^{32}$ The petitions of the Evangelical bourgeoisie dwelt on three points: the imminent danger of the wrath of God if the capitulary Masses were allowed to continue (especially upon wives and daughters who, with other weak souls, would insist on hearing Mass); the Mass's apparent contradiction of Scripture; and, finally, the division and social unrest caused by coexistence of two kinds of rite and preaching, ${ }^{33}$ We shall consider the content of the preachers' petitions in detail later in this chapter. Apart from demonstrating that the Mass was contrary to the Word of God, the aim of the preachers was to convince the magistracy of its right and duty to abolish the Mass completely. The longer the magistrates delayed, the greater the urgency with which this theme was aired. A 1528 memorandum by Bucer was entitled, Das die Mesß $\beta$ die schwerist gottisscbmach vnd abgotterey wnd von keiner cbristlichen oberkeitt zu dulden sey. ${ }^{34}$ Elsewhere, the preachers recalled the example of Josiah's reform of the worship of Judah ( $2 \mathrm{Kgs} 22$ \& 23). Romans 13 was also frequently cited, less to emphasise the need for obedicnce to secular authorities, than the magistrates' responsibility to God for the good of those under their authority. ${ }^{35}$

From the Catholic side, the Rat was alternately petitioned and thrcatened by the bishop of Strasbourg, Wilhelm von Hohnstein, and by the chapters of the capitulary churches. These reminded the Rat of its responsibility to observe the terms of the Recesses of Worms (1521) Nuremberg (1523) and then Speyer (1526) which had forbidden all innowations until an Imperial Diet or council of the church

\footnotetext{
${ }^{30}$ Ibid., 246-254. Karlstadt had arrived in Strasbourg in Oct 1524 .

${ }^{31}$ This assembly of 300 delegates drawn from the guilds formed a sort of lower house in the Strasbourg magistracy. See Chrisman, 25-26.

${ }_{12}$ BDS 2:505, "Darumb g. h., so lang jr die fier greuelichen, Abgöttischen vnd gortzlesterlichen Messen dulden... würdt der geschrift nach tait zu hoffen sein, das doch ein lidliche bösserong [sic] bey vns vffkümen möge." 'The preachers' petirions ate found in BDS 2:468-537. One of the burghers' petitions is found in BDS 2:427-42, n. 17. See also Bocnert, 69-70, 101-102, 137141; Chrisman, 167-170.

${ }^{33} 7$ bid., $167-168$.

${ }^{34} \operatorname{MDS} 2: 532-537$.

${ }^{25}$ I3DS 1:200-203; BDS 2:472-473, 493-496, 503-506, 513-514, 541.
} 
should decide otherwise. ${ }^{36}$ In 1527 the bishop proposed a programme of liturgical reform allowing greater use of the vernacular in the administration of the sacraments, more diligent preaching of the Word, a reduction in the number of Masses for the dead and measures for the suppression of various other "abuses," Nothing canc of this programme, however. The preachers, for their part, were keen to stress that, despite constant promises of a reforming council, there was no genuine will for reform on the opposing side. ${ }^{38}$ Since the massing-priests and thcir ilk could not demonstrate the Scriptural foundation of their Mass, the Rat might at the very least abolish the remaining Masses until a free general council had rcached a decision on the tratter. ${ }^{39}$

\subsubsection{From the Abolition of the Mass to the Early 1530s}

In 1530 Bucer and Capito collaborated on the first draft of what would become the Tetrapolitan confession, presented at the Diet of Augsburg. Bornert correctly describes the Tetrapolitana's chapter on the Mass as a summary of the usual objections. ${ }^{40}$ Both its first and final drafts protested that the Evangelical preachers would have preferred not to have modified the Mass without the authority of the Emperor or princes, but it was so manifestly offensive to the glory of God that they had been obliged to act unilaterally. ${ }^{41}$ What is interesting is that in both the Tetrapolitan confession and the Apology (completed in 1531) Bucer protested that the received understanding of eucharistic sacrifice was not that which had been held by the fathers. The Tetrapolitan confession simply noted that the Mass was contrary in "so many ways" not only to the divine institution of the Lord's Supper, but also to the custom of the "older and purer church and also the teaching of all the holy fathers." ${ }^{32}$ The Apology repeated this argument, but this time Bucer was ready with a number of patristic sententide with which to illustrate his point. Without citing any particular passages, the Confutation of the Tetrapolitan confession had listed Dionysius, Ignatius, Irenaeus, Tertullian, Origen, Cyprian, Basil, Eusebius, Ambrose, Jerome, Augustine, John Chrysostom, John Damascenc among, "orher Christian teachers who have taught the sacrifice for the living and the dead." It also named Lawrence as one who had shed his blood for it. ${ }^{43}$ Bucer was

\footnotetext{
${ }^{16}$ See e.g. Ibid., 2:428, 435, 498, 509.

${ }^{37}$ Bormert, 140.

${ }^{38}$ See e.g. BDS 2:50?

${ }^{39}$ Ibid., 498.

${ }^{40}$ Bornert, 387. See BDS 3:134-143.

${ }^{41}$ Ibid., $140-143$.

${ }^{42}$ Ibid., 140-141, "Seytenmal dann die Messen in so schweeren missprauch gerathen sein, das sye gottlichem gesatz wie autch dem prauch der elltern vnnd Rainern kïrchen, auch lecre aller haylligen Vitter in so vil weg vand gar vil mer, dan hie erzelet, zuwider sind."

${ }^{43}$ Paetzold, Die Konfutation des Vierstüdtebekenntrisses, (Leipzig, 1900).
} 
not bound in principle to reply to this list of authorities. In De coena dominica, for example, he had written to Murner: "when we name them [i.e. the sacramental elements] 'bread and wine' we speak as the Apostle; when you affirm that nothing is left of the bread and wine but accidents, you speak as 'Thomists', or (in order to exculpate yourselves as much as possible) as 'Ambrosiists' or 'Patrists." ${ }^{34}$ In the Apology, however, Bucer replied that the saints listed by the Confutators had never dreant of such a sacrifice as the papists now celebrated and the Confutators themselves attempted to defend. ${ }^{45}$ In one sweep the fathers from Dionysius to Damascene were claimed for the Reformation. Whence this confidence?

First of all, the use of the fathers in an official confession of faith was politic. As we noted above, a number of Imperial Diets had urged the Estates to safeguard the traditional customs and ritual of the church and to prevent the introduction of innovations. The Diet of Speyer in 1529 forbade the suppression of the Roman rite specifically, and the representatives of Strasbourg had protested that such a prohibition ran counter to their consciences. ${ }^{46}$ In April 1530, Bucer wrote to Ambrosius Blaurer that he was considering how he would defend the ceremonial innovations to the Emperor." An appeal to the "fathers" in the Tetrapolitan confession and its Apology would go some way towards countering the impression that Strasbourg, Memmingen, Constance and Lindau had been "innovating." If the writers of the Confutation of the Tetrapolitan confession claimed that the Evangelical view of eucharistic sacrifice ran counter to that of Tradition, then it would help the Evangelical case to be able to show that the Confutators' very "tradition" was itself an innovation.

Moreover, Bucer's interest in demonstrating the patristic foundation of Evangelical cucharistic doctrine had an ambit wider than the Empire. Strasbourg's location and role as a haven for Evangclical refugees from. France encouraged him to take an interest in the fortunes of the Reformation in France. His Psalms commentary of 1529 was dedicated to the French Dauphin, François de Valois. However it was probably as much intended for Francis I who at this time was perceived to be favourably disposed towards the Reformation. ${ }^{18}$ In the

${ }^{44}$ BOL 1:34, "Igitur cum nos panem nominamus et vinum, loquimur ut Apostoli, cum vos affirmantes, nihil hic reliquum panis et vini, praeter accidentia, loquimini ut Thomistae, vel ut maxime vos purgetis... Ambrosilistae vel Patristac.:

${ }^{4 j}$ BDS 3:289. Cf. Tetrapolitana 18 (ibid., 133), "... Von disen württ bey vnns gelert vnnd gepredigt, wie das von den Euangelisten vnd Paulo furgeschryben vrnd von den haylligen Vättern gehalltcn..."

${ }^{45} \mathrm{Jedin}$, A History of the Council of Trent, transl. E. Graf, 2 v. (London: Nelson), 1:247.

${ }^{47}$ Schicess 1:209, no. 162.

42 L. Hazlett, "A I'ilot-study of Martin Bucer's relations with France, 1524-1548," in Martin Bucer and Sixteenth Century Esrope, ed. Krieger, 2:512-521. For the dedicatory cpistle see BCor 3: 301-301. 
commentary, Buccr would attempt not only to appropriate the language of the "repetition" of Christ's sacrifice, but would do so with an appeal to Thomas Aquinas and Peter Lombard. Again the fathers (including Aquinas) offered respectability to Evangelical eucharistic doctrine: a preparatio evangelica helping to gain Evangelical doctrine an entrée at the courts of sympathetic Magistrates.

Bucer's biblical commentaries of the late 1520's were also addressed to an international Evangelical readership. They werc intended, first of all, to explain the new biblical hermeneutics. In a 1527 letter to the Strasbourg Rat, Bucer noted the danger posed by patristic allegorical excgesis (Chrysostom excepted) for less experienced readers of Scripture. Allegory, wrote Bucer, was used to support false interpretations of the "mysteries of Christ" (i.e. the sacraments) and "the Masses." In his scriptural commentaries he wished to draw the fratres rudiores of France and Italy away from such exegetical trivia to the "germane sense" of Scripture and to edification in faith and love. In the same place, Bucer remarked that he hoped the commentaries would assist readers, etiam post patmm scripta. ${ }^{49}$ Thus, even if Bucer's Jobn commentary did not cite and discuss the fathers as explicitly as his later Romans commentary, patristic exegesis was nevertheless an implicit (and sometimes explicit) point of reference throughout. ${ }^{56}$

\subsection{Bucer's Early Critique of the Mass}

We will consider Bucer's critique of the received understanding of eucharistic sacrifice under three headings. The first of these is the mutilation and subversion of the institution of the sacrament. The second is the ethical and ecclesiological dimension of the Lord's Supper. The third is the status of the church's liturgical or ceremonial tradition.

\subsubsection{The Mutilation of the Divine Institution of the Sacrament}

The institution narratives of the Synoptic Gospels and 1 Corinthians 11:2326 confirmed for Bucer that the orientation of the Lord's Supper was, firstly and fundamentally catabatic: i.e. a movement from God towards humans. Because Jesus had given the command to take, cat and drink: "it is clear that we must receive his body and blood just as his apostles did. Of the offering which those who call themselves "priests' now suppose they perform, he says nothing." ${ }^{21}$ At this point sacrifice was synonymous in Buccr's mind with the idea that we give something to

\footnotetext{
4) $\mathrm{BOL} 3: 16-17$.

50 See I. Backus, "Introduction," BOL 3:xiii ff., and "Martin Bucer and the Patristic Tradition," in Martin Bucer and Sixtecnth Century Europe, ed Krieger, 58-62.

${ }^{51}$ Simmary (BDS 1:117). See also Grund und Ursach (BDS 1:210-211).
} 
God, "as when I give a brother alms." 52 To call the sacrament itself a "sacrifice," could only mean that it was a new, independent or at least devolved sacrifice. ${ }^{53}$ If Christ really had instituted a sacrifice, why did the priests not follow his example by offering their own bodies, rather than attcmpting to crucify Christ's again and again $?^{54}$ The priesthood of the Mass, the claim to offer it as a sacrificc and a good work for the living and the dead, and the sacrificial paraphernalia which accompanied it stood in direct contradiction of the witness of the Epistle to the Hebrews. The Church had one priest, one altar and one sacrifice. ${ }^{55}$ Christ had offered for us once on the cross and his sacrifice availed forever. There was now no need of a sacrifice for sins. ${ }^{56}$

\subsubsection{The Ethical and Ecclesiological Dimensions of the Eucharist}

However, the anabatic aspect of the Eucharist (i.e. the human response founded on the divine initiative) was never far from the forefront in Bucer's discussions of the institution of the sacrament. IJammann notes Bucer's tendency to leap straight from Luther's soteriology into ecclesiology, and this is also the casc with his theology of the Eucharist. ${ }^{57}$

In his treatise Das ym selbs niemant, sonder anderen leben soll (1523) Bucer had argued that the goodness of human creatures consisted in their existence for other humans. In this way they fulfilled the end for which they had been created and thereby lived for God. Fallen humanity, however, lived for itself. This disorder would be re-ordered in so far as, "in all his dccds he [i.e. the human creature] seeks not his own welfare, but that of his neighbour and brother to the honour of God. ${ }^{38}$ Through the re-ordering of their existence in this way humans would also learn to exercise proper stewardship over creation which was made to scrve them. ${ }^{59}$ In this sense, to love one's neighbour as oneself was the fulfilment of the whole law. God required no worship from us other than the works of mercy. ${ }^{60}$ The second part of the treatise outlined the process through which such reordering took place. It began through faith that Christ alone had obtained the mercy of the Father by the shedding of his blood. It was brought to perfection through re-creation by the

\footnotetext{
${ }^{52}$ De caena (BOL 1:49).

${ }^{53}$ Dass D. Luthers (BDS 1:231), “... in kein weg mag sy ein opfer sein, das vff eins newes do Christus wurd vffgeopfert."

${ }^{5+}$ BOL 1:48.

${ }_{55}^{5}$ Grund und Ursach (BDS 1:214).

${ }^{56}$ See e.g. BDS 1:117, 212-213, 234, 330-331; BDS 2:453, 488, 526; BDS 7:136-137; BOL $1: 47-49$

${ }^{57}$ Hammann, 33, 35-36.

${ }^{5 R}$ BDS 1:51.

${ }^{59}$ Ibid.

${ }^{60}$ Ibid., 51, 63, 66.
} 
Spirit of Christ. ${ }^{61}$ Such faith was always weak and imperfect in this life, but where faith was present, the service of one's neighbour to the glory of God was always present as well. ${ }^{62}$ Likewise the absence of love of neighbour was a certain sign of the absence of true faith.

As we have already noted, the "ground and basis" of Bucer's liturgical reform, was that worship must observe the injunctions of God set forth in the Scripture. The liturgical reforms recommended in Grund und Ursach were justified as follows: "because we know both that the Spirit of God alone can know the things of God (1 Cor 2:10-11), and that divine Scripture contains everything which is good (2 Tim 3:16), in the fellowship of God we use no song or prayer which is not taken from divine Scripture..." ${ }^{63}$ In this period of Bucer's career, liturgical reform meant not only a return to Scripture, but the elimination of anything which was not found in Scripture. Das Niemand sich selbs, however, suggests how wrong it would be to imagine that in this early period Bucer's liturgical principles amounted to a straight-forward biblicism. In fact the twin and inseparable principles of faith and love of neighbour - the sum of the law - were, and would remain, fundamental to Bucer's liturgical programme. What would change was Bucer's understanding of how love of neighbour was to be realised.

In De coena dominica Bucer took up and defended Luther's contention that the sacrament of the Lord's Supper was a testament. Like Luther and Zwingli, Bucer treated "testament" as a synonym for covenant (foedus). More than Luther, however, he emphasised the human side of the covenant: in the sacrament we have, "both what the Lord promises as well as what is required from us in return." "The fruits of God's testament and promise werc that "we raise the faith our hearts to God and, justified by this, we live now not for ourselves but for the Lord, ascribing truth and mercy to God and devoting ourselves to love our neighbours." ${ }^{165}$ The summa of the Evangelical Mass was not simply the institution accounts, but also Paul's words in 2 Cor 4:10, "we carry about the death of the Lord Jesus in our bodies, so that the life of Jesus may be visible in our body." "is

Love of neighbour was necessarily connected with another prominent thome

"I Ibid., 60 .

${ }^{42}$ Ibid, 65 ,

(3) Ibid., 275.

${ }^{64} \mathrm{BOL} 1: 25$.

${ }^{65}$ Ibid., 51. Cf, the priest's Vermanung in the outline of a desirable order for the celebration of the Lord's Supper BDS 1:246.

("s De caera (BOL 1:23), The people eat and drink the elements, "annunciantes, quan hace repraesentant mortem Servatoris, pro abolitione peccatorum nostrorum obitam, qua certu victorian partam nobis, peccati, mortis et inferni gloriamur, ut liceat Domino servire in laetitia, quantumlibet nos peccatum in carne urgent, et cruce excrceamux, mortificationem Domini Jesu in conpore circumferentes, ut et vita Jesw in corpore nostro manifestetwr." 
in Bucer's writing on the Eucharist" the communion of believers with one another and with Christ in the fellowship of the one body. In Grund und Ursach Bucer noted that Paul had called the sacrament Gemeinschafft; a name which remaincd among the Greeks [as Synaxis] and among the Latins as "Collect." The antichrists with their sacrifices had seen to it that the memory of this latter title had almost disappeared. ${ }^{67}$ For this reason Bucer proposed that a single service on Sunday replace the daily Mass, that a single common table replace the multiple altars, and that the people be encouraged not merely to hear the Mass, but to share al the one tabie. In this common celebration the people would recall their common redemption from sin by the sacrifice of Christ's body and blood so that they had now had nothing of their own but held everything in common in the fellowship of the one bread and the one body. 68

This emphasis on the corporate dimension of the etcharistic memorial became still more pronounced as Bucer began to veer from an unreflectively Lutheran understanding of the eucharistic presence toward the position taken by the Swiss reformers." His eariy emphasis on the necessity of "spiritual" consumption of the sacrament and its consequences gradually led Bucer to question why the sacramental presence of Christ's tlesh was necessary at all." "Eating and drinking the body and blood of Christ" became believing that he had given up his body and shed his blood to save us. In so doing, the faithful testified to the fellowship which they had with all those who partook the same bread. ${ }^{\text {.1 }}$

However, the corporate dimension of the Eucharist would also feature prominently in Bucer's re-appropriation of the language of "bodily" and "substantial" presence from the early 1530s. Christ was received substantially and bodily by those who lived in him as he in them (John 5:56) flesh of his flesh and

${ }^{6}$ Ibid., 243. He may have this from Erasmus, (e.g. Stultitide laus (LB 4:465C)) Zwingli (c.g. De verd et falsa religione 18 (CR 90:807)) or Luther (e.g. Sermon von dem bochwirdigen Sacrament (WA 2:743,7-10)) but these names for the Eucharist wrere widely recognised in mediaeval commentary, see c.g. Altenstaig, Lexicon theologicum, 102b, "...Dicitur, sinaxis, id est communio quo ad finem in via,..."

${ }^{68}$ BDS 1:242. See also ibid. 1. 28ff.

(9) This is not to sugyest that the corporate and ethical dimension of the Eucharist was absent in Luther. His Sermon von dem bochwirdigen Sacrament (WA 2:742-758) contrasts the Eucharist as Gemeinschafft with the false fellowship of the confraternities and, inter alia, their extravagant expenditure on Masses. Howcver, the Sacramentarian Controversy would push this aspect into the backsground.

${ }^{70}$ Hazlctt, Development,54-90; Hamrnann, 36.

${ }^{71} \mathrm{Sec}$ c.g. Bucer's controversial additions to his translation of Bugerhagen's In librm psalmonm interpretatio (1524) in BDS 2:218-219, esp. 219, 1. 21-26, " $\ldots$ das brot zuo brecher1 und den trelch under uns zuo teylex, dobey wir bendencken sollen und im des danck sagen, das er sein leyb und bluot uns zuo erloesung hyngeben hat, das dann mit im bringt die verbruederung mit allen, die solchs glauben genossen sind, mit denen wir ein brot und ein lcyb sind, dic wir allc eins brots teylhalft sind." See also In Evangelion Iohannis (BOL 2:271), "... quis dubitet et hoc T?auli loco [i.e. 1 Cor 10;16] koinonian pro: socictate accipicndam?" I-Lazlett, Development $47 \mathrm{ff}$, 
bone of his bone (Eph 5:30 (Vulgate)).$^{72}$ As we shall see, this participation in Christ's body was not something static and complete, but a reality into which believers were gradually incorporated in the repeated celebration of the sacrament. In the 1530 s Bucer would also adnit that the extenal administration of the sacrament was an instrument by which the Holy Spirit realised this einleybung in those who were members of Christ's body by faith. ${ }^{73}$

The converse of the positive theology of the Eucharist outlined above was Bucer's condemnation of the Mass on the basis that it overthrew the love of God and neighbour on which the law depended. ${ }^{74}$ In the Summary the multiplication of Masses was criticised because it encouraged the misuse of created goods. What should have been given to the poor, in accordance with the command of God, was used to fund and encourage the simoniacal, low-living of the Mefling and Mefsmacher ("massing-priests") rattling off their soul-masses. Their faithless celebration of the Mass was reflected in the loveless quality of their lives. ${ }^{75}$ To allow this to continue was also no service to the Massing-priests as fellow Christians. The terms of their employment forced them into a position in which their Mass-stipend was always their primary consideration, and they were thus almost forced to consume the body and blood of Christ unworthily. ${ }^{76}$

Grund und Ursach advocated the abolition of the priestly vestments with their costly fabrics and ornamentation because they cncouraged pomp and pride and stood in the way of brotherly love and almsgiving. ${ }^{77}$ Altars were likewisc to be removed because the moncy spent on them would better have been given to the poor. ${ }^{78}$ These things were also abolished because they made a sacrifice of the Lord's Supper. ${ }^{77}$ However, for Bucer the traditional theology of eucharistic sacrifice was not simply an abstract theological error. It had practical and moral consequences,

${ }^{72}$ See e.g. Reply to Bonifacius Wolfhart (1532) (Pollet Études 1:95) "Siquidem... sic nobis Christus exhibeatur, ut ille in nobis, nos vero in ipso simus, caro de carne eius et os de ossibus, membra et corpus eius, certe inficiari non licet eum exhibere coque adesse substantialiter et corporaliter, nisi non adsit vivo corpore [sic] sum caput et ncmbra invicem vitisque palmiti substantialiter et corporaliter." See also Hazlett, Development, 322.

${ }^{73}$ Hamnann, 230.

${ }^{74}$ Grund und Ursach (BDS 1:195).

75 Summary (BDS 1:116, 120) "... sobald sye über einander geschlappert haben ire Seeimesßen, von sturd an ins würtzhuß lauffen, fressen und sauffen den gantzen tag, spilen und treiben die unzüchtigsten wort als von lscim reiter noch kriegsknecht gehoert wiirdt? Und ob aber schon diser groben sünd keine geschicht und ist allein glaubloß und liebloß leben..."; ibid., 121, 123124, "Darumb mein allerliebsten brueder, spart eüwer gelt, belfft den eïwern und andern armen damitt, wie eiich grott gebotten hatt..."

${ }^{76}$ Ibid., 120-121.

77 Ibid., 233-234; BDS 2:447; BCor 2:86; Cf. Luthcr, Semon von dem bodbwirdigen Sacrament (WA 2:755, 5-24).

$7 \mathrm{Grund}$ und Ursach (BDS 1:24I-242).

${ }^{79}$ Summary (BDS 1:117, 124). 
because faith and love were inseparable. ${ }^{\text {yo }}$

\subsubsection{Prayer for the Dead}

It is interesting in this respect that (because of its theoretical connection with love of neighbour) Bucer was not prepared to ccusure prayer for the dead unconditionally. There was certainly no word about Purgatory to be found in Scripture, for 2 Maccabces was not a biblical book. ${ }^{81}$ To pretend to offer Mass for the living and the dead was to forget that we have Christ as an advocate who makes intercession on our behalf for ever. Intercession made in Christ's name was not the preserve of the Massing-priests, but of the whole Christian community. ${ }^{82}$ On the other hand, one should not refuse the genuine, if confused, love of those who wished to commend the dead to the Almighty with faithful prayer. Such prayer, however, should be made only once or thrice (i.e. as opposed to series of Masses) with trust that it was heard by God. ${ }^{83} \mathrm{By} 1529$, Bucer hardened his position. In the Epistola apologetica he argued that since prayer was a work, not of our will, but of the Holy Spirit in us, praycr for the dead was unlikely to be true prayer: i.e. the Holy Spirit made no mention of it in Scripture. ${ }^{84}$ Yet, even here, he allowed that the "faithful soul" could pray for the dead because the breadth of God's counsels could never be known, and it was possible that, even after death, God's name was hallowed, and his kingdom perfected and obedience to his will fulfilled in his elect. ${ }^{85}$ Moreover, "after a manner of speaking," to mourn the dead (moderately) and hope for the resurrection for them remained, "a duty of brotherly love." 86

\subsubsection{The Status of the Church's Liturgical Tradition}

\subsubsection{Cbristian freedom and the interior and exterior dimensions of Cbristian worsbip}

Beyond the contention that the Eucharist had not been instituted as an offering of the body and blood of Christ, two other related principles governed Bucer's approach to the Mass - though with changing consequences. The first was a distinction between the interior and exterior aspects of worship. The second was that of Christian freedom.

In Grund und Ursach the criterion of worship "in spirit and truth" (John

${ }^{80}$ Grina tond Lrsach (BDS 1:234).

${ }^{81}$ Summary (BDS 1:115-116).

${ }^{82}$ Ibid., 124.

${ }^{83}$ Tbid., 125. Sec also ibid., 143.

${ }^{84}$ BOL 1:106.

${ }^{85}$ Ibid., 107.

${ }^{86}$ Ibid., 106. 
4:23-24) served as warrant for the abolition of the gestures made by the priest during the Mass (i.e. bowing, the sign of the cross, kissing of the altar, striking of the breast, elevation of the hands). ${ }^{87}$ Christians were no longer bound to the shadows of the ceremonial Law (Col 2:17; Gal 4:8-9). Christ had fulfilled the ceremonial priesthood of $\Lambda$ aron, with its rituals and vestments, and entered into the true sanctuary. The priestly vestments of Christ were not made with hands, but were truth, judgement and righteousness, which all the baptised shared when they put on Christ (Gal 3:27). Insistence on the use of vestments persuaded the people that scoundrels were holy, and thus strengthened and sustained superstition, meanness and malice. "The planting," Bucer wrote, "is not by the Father, how then could it bring forth good fruit?" ${ }^{\prime 8}$ Rather, the work of the devil was evident in the ritual of the Mass. ${ }^{89}$ 'True worship was Spirit because it flowed from the prompting of the Spirit of Christ. It was true because it accorded with Scripture in which the Spirit declared how God desired to be worshipped. It was spirit because it sprang in the elect from the gift of faith which was effective in love. It was true because love did not require elaborate rituals and external signs to give the sensible impression of piety.

During this early period, Bucer tended to treat Christian freedom regarding external ceremonies as freedom from then. However, Bucer's insistence on Christian freedom qualified and nuanced his insistence on worship in spirit. Grund und Ursach, for example, advocated the abolition of the elevation of the host because it strengthened the people's belief that the Mass was a sacrifice. Following Luther, Bucer believed that this practice had its origins in the setting-aside of portions of the food-offerings in Leviticus $2: 9 \& 4: 8$. He also believed that the pagan Romans had a similar practice. ${ }^{90}$ Either was sufficient grounds for its abolition. Yet, Bucer wrote, the preachers had borne with this and other popish ceremonies until the weak could be properly instructed in the Word. In the meanwhile they had thought it sufficient to emphasise that the elevation did not mean that the priest wished to offer the Lord's body and blood again. Rather, it reminded the faithful that Christ was lifted up on the cross and offered once to the Father. He acknowledged the criticism that the preachers had proceeded too slowly in this matter, but he emphasised that Christians were not longer bound to the elemental principles, and that to the pure all things were pure (Gal 4:3, 9; $\mathrm{Col} 2: 20$;

${ }^{87}$ BDS 1:237.

${ }^{98}$ Ibid., 234.

${ }^{89}$ Thid., 234-23.

${ }^{93}$ Ibid., 218. Cf. Luther, Wider die bimmlischen Propheten. (WA 18:118) where Luther attributes the argument from Leviticus to Karlstadt, and rejects it. Luther does not mention the pagan origins of the practice. 
Tit 1:15).The use of outward things was always to be determined by a Christian's obligation to serve his or her neighbours for their betterment. Paul for example had circumcised Timothy to assist his work among the Jews of Lystra and Iconium (Acts 16:1-3). As Paul said of himself: "I became all things to each person so that ix everything I might make some of them holy" (2 Cor 9:22). ${ }^{91}$

Here the elevation was not ultimately a thing indifferent, as it was for Luther. ${ }^{92}$ Because of its origins in the Jewish and Pagan sacrificial cult, it would eventually have to be abolished. For the meanwhile, however, it could be neutralised by attaching a new significance to it: i.e. as a memorial token of the crucifixion. Hete already we have the essence of the policy pursued by Bucer throughout the era of the colloquies: faith active in the works of love as the sum of the law; the consequent obligation to bear with the weak; the consequent freedom with regard to outward ceremonies and liturgical legislation; re-interpretation of those ceremonies as a way of leading the weak toward the fullness of the truth. During the 1520 s however these criteria were offered largely as reasons for the wholesale abolition of the traditional rite.

\subsubsection{The Eucbaristic-Sacrificial Tradition}

\section{a The Roman Canon}

The interim toleration of the elevation could not, however, be accorded to the Roman Canon. Like Luther and Zwingli, Bucer regarded its words as the mainstay of the antichrists' doctrine of sacrifice, and the refusal of his opponents to countenance its abolition was evidence of their bad faith. As we have already noted, mediaeval theologians, such as Heinrich von Langensteitl, belicved that the "substance" of the Mass resided in the words of Christ. In De caena dominica Bucer asked his adversaries why they were not content with the words of Christ if they held their Mass to be the same as that which he had instituted. He continued:

who do you imagine is the author of that whole sacrosanct Canon of yours? How is it that when Christ instituted this supper as a celcbration of his momorial, you have made it a remedy against all misfortunes and instituted the most filthy source profit ever dreamt of in this world? The dung of human traditions and the stench of hell which emanate from that wicked Mass of yours, suggest who its author is. ${ }^{33}$

\footnotetext{
${ }^{11}$ BDS 1:219.

${ }^{92}$ See e.g. Luther, Von Anbeten (WA 11:448).

${ }^{23}$ BOL $1: 53$, ${ }^{\alpha} .$. Stercus humanarum traditionum, et fetorem inferni vestra scelerata missa olet, auctorem referens."
} 
Grund und Ursach recommended the, "little book on this Canon (i.e. De canone missae epicbeiresis) quitc recently published by Zwingli the highly-gifted Apostle of Zürich." Bucer remarked that he had nothing to add to what Zwingli had written on the subject. ${ }^{94}$ For example, he would follow 7.wingli in accepting Reuchlin's derivation of missa from the Hebrew. It was because of this that Grund und Ursach advocated the abolition of the name "Mass."

A 1526 report by Strasbourg preachers (Bucer appcars to have been the principal author) declared that, "almost the entire Canon is a blasphemy," and undertook to demonstrate this with an analysis of some of its prayers as Luther had done in Vom Greuel der Stillmesse and 'Zwingli in De canone missae epicheiresis." For the benefit of the magistrates, the preachers' report translated the Suscipe of the "minor" Canon. They also summarised the content of the Unde et memores and the Supra quac propitio: two of the prayers following the consecration. Of the Suscipe the preachers wrote:

See what a blasphemy it is: before the consecration he offers up a bit of bread and wine to God for his own sins and those of all Christians, living and dead, for their salvation and eternal life. The death of Christ alone has effected and provided for this. Is this not a mockery of God and an abominable blasphemy against Christ? He says the same sort of thing after the consecration oncc he has elevated the sacraments."

Of the Unde et memores and the typological offerings of Abel, Abraham and Melchizedek mentioned in the Supra quad propitio, they commented:

Sce, there he himself intends to offer Jesus Christ and he, a poor sinner prays first that God the Father will deign to accept him with a favourable countenance as he did Abel's sheep, Abraham's ram and the bread and wine which Melchizedek gave to Abraham and his fighting men to eat after battle. But what blasphemous mockery is this?... The. whole Canon, the best and principal part of the Mass, is full of it. Let each Claristian now judge what is to be thought of the Mass!"

\footnotetext{
${ }^{15}$ BDS 1:237.

${ }^{75}$ BDS 1:209. Cf. Zwingli De canone (CR 89:567). For Reuchlir's etymology, see above, ch. 3 , p. 49 .

76 Predicanten Bericht der Mcssen balb (BDS 2:488), "Der gantz Canon is vast gotzs laesterlich, wie tttliche [i.c. Luther and Zwingli] antag bracht haben." Cf. WA 12:211; 18:8-36; CR. 89:556-608.

${ }^{77}$ BDS 2:489. Cf. WA 18:25, 13-15, "Sollen wir Gotte eyrnen byssen brod und weyn anbieten, das er annemen wolle fur die Christenheyt? und dazu sagen, Fs sey eyn hcylig unbefleckt opffer?" Neither Luther nor Zwingli, however, analyses the prayers of the ninor Canon. In the passage cited here, Luther is discussing the Te igitur.

${ }^{9 B}$ BDS 2:489, "... Dyses ist nun der gantz Canon voll, das best vnd haupstuck der Meß; vrteyll nun ein jeder Christ, waß von der Meß zuo hallten sye!"
} 
Similar comments on the Sippra quae propitio appear in Bucer's memorandum That the Mass is the worst sacrilege written a few months before the abolition of the capitulary Masses. ${ }^{29}$

b The Indefectibility of the Church

Another concern of the 1526 preachers' report was to answer the following question asked by a "simple" soul (probably a puzzled magistrate): if the Mass was so dreadful, how could it have been tolerated for so long and by so many holy people? 'The answer was twolold. Firstly, the ancients did not regard the Mass as a good work and sacrifice, but as the memorial of the good work and sacrifice which Christ made once for us on the cross. Secondly, Christ had warned in Matt 24:24 of signs and portents which would deceive even the elect, and since God had permitted the existence of idolatry, false preaching and an imperfect humanity for four-thousand years under the Old Testament, he could not be reproached if he had let the error of the Mass prevail for a few hundred years and was now restoring the truth through a small number of people. ${ }^{100}$ 'The first part of the preachers' answer hints that there may once have been a legitimate sense in which the sacrificial vocabulary of the Mass could be interpreted. We shall return to Bucer's development of this theme shortly.

The second part of the question situates the Mass in the wider Reformation debate on the authority of tradition and the church. As we noted at the outset, Bucer had written on this theme in Kuttzer wearbaffiger Bericht, his reply to Treger's Paradoxa. Treger had voiced similar objections to those attributed to a simple questioner in the 1526 preacher's report: firstly, if the received understanding of eucharistic sacrifice was incorrect, then the church had been abusing the Eucharist and blaspheming for centuries; secondly, if it were claimed that the true "invisible" church had never committed such abuses, then how was this church to be identified? ${ }^{101}$ Bucct replied to what he described as das argament seculorum by producing Acts 11 as an example of the earliest church's error concerning the vocation of the gentiles. This, he remarked, was no minor error, but one which was contrary to the entire Scriptures of the prophets and Christ himself. ${ }^{102} \mathrm{How}$, then, could the primitive church be said to have prevailed against

${ }^{2}$ Das die Mes $\beta$ ist die schroerist gottischmach vnd abgottery (BDS 2:53.5).

${ }^{100}$ Ibic., 490-491.

101 Ein kurtzer wahrbaffiger bericht (BDS 2:103, 120-121). Sec c.g. ibid., 120-121, xli. Wunderred. Zuom fürgenommenen, so von tausent jaren haer und weiter uns mit uffopferung des leibs Christi und it annemung der sacramenten mithellig gewesen seind alle, dic christlichen nammen verjehen haben, welche voelcker, welche leüt seind dann ewex unsychtbare Kirch [sic], die ir sagen, das sye nit yrren noeg und glaubt haebe wrie ir glauben?"

${ }^{102}$ Ibic., 105, 108; Cf. Luther, De abrogania (WA 8:411, 21). 
the gates of hell (Matt 16:18)? The answer was that:

the true community of Christ, i.e., the church which is established and fixed on Christ does not err on the principal points and necessary articles of the faith, namely that divine Scripture is true and she never yiclds on what it teaches: that through Christ alone, by grace, we become good and holy. ${ }^{103}$

Even in denying the vocation of the gentiles, the primitive Church had remained built on this foundation. ${ }^{30 t}$ Likewise, then, Gregory and Bernard and other "dear holy fathers" had erred in many things, especially in so far as they had accepted much in the worship of God which was inconsistent with Scripture. Yet their foundation was Christ. ${ }^{105}$ Holiness, was not something received all at once, but something into which both the individual and the church must grow. Bucer quoted Ephesians 4:11-15 and commented: "Here we hear that the body of Christ, which is the true Christian church, must daily be improved, that is, we must increase and grow in the knowledge of Christ." "Just as knowledge and faith in Christ were deficient, so the worship of the church was always deficient and, to some extent, in violation of the first commandment to love God with the whole heart. ${ }^{107}$

Herc we see what Hammann identifies as an increasingly important theme in Bucer's ecclesiology: that of the individual's and the church's progression and increase towards maturity and final glory. ${ }^{108} \mathrm{lt}$ is not just a case of the corpus mixtum in which wheat associate with tares in the outward fellowship of the baptised. Bucer insisted that the church is invisible and not coextensive with the outward fellowship of the baptised. He insisted that it was recognised where the pure Word of God was preached and Christ acknowledged as head. However he also claimed that it might be recognised where those who dwelt in love brought forth the fruits of love from faith. ${ }^{109}$ In this respect the church was never perfect, but always on its way toward perfection.

${ }^{103}$ BDS 2:103. See also ibid. 85, 89.

${ }^{104}$ Ibid., 104, 106.

${ }^{105}$ In his choice of falthers and in his argument Bucer is probably inflenced by De abrogandet (WA 8:413-414, esp. 414, 7-14).

${ }^{106}$ Fin kurtzer wabrbaffiger Bericht (BDS 2:106).

${ }^{107}$ Ibid.

${ }^{108}$ Hammann, 36-37.

${ }^{209}$ See e.g. ibid. 113, "Dann die christlich Gemeyn nichts anders ist, dann dic gemcynschafft der hcyligen, das ist der glaeubigen. Und die ist ye unsichtbar, dann wir glauben syc, das were nit, wo wir sye sehen. Aber seitenmal syc, die im lieb wallen, bringen sye irc guove fruecht, dabey kennet man sye. Und darumb wo man das wort gottes lauter prediget und gern hoeret, da man Christo underthaenig ist, da man Christum erkennt als ein haubt, da glaubt ein yeder das ein kirch sey." 
Again, the constituent parts of Bucer's later policy towards the Mass are already present here. Even when its members laboured under the gravest doctrinal error the true church persisted in the proclamation of the pure Word of God and obedience to it. The pure Word of God was not associated here with a kind of biblicism, but with obedience to the proclamation of faith in Christ which bears fruit in the works of love. It was possible for one of the elect, for a church or for the church's preaching to be seriously compromised by idolatry and yet to remain built on the foundation of Christ and to produce the fruits of love - however imperfectly. According to this criterion, as Bucer would later confess, there were churches of Christ among the papists. This did not just mean that there were convinced crypto-Evangelicals - "Nicodemites" - biding their time in Catholic territories. It also meant that there were weak and deluded members of the body of Christ, addicted to the ceremonies of the papal church and reluctant to abandon this milk for the solid food of Evangelical worship. Since the vocation of Christians was to live for their neighbours, to leave the weak in their error would not do. They had somehow to be weaned away from it. In the 1520 s Bucer would attempt to accomplish such weaning as quickly as possible. In the 1530s, however, a gradualist approach would seem more expedient.

c The Eucharistic-Sacrifical Vocabulary of the Fathers

This gradualist approach would be assisted by Bucer's growing conviction that the ritual of the church had not always had the same superstitious significance attached to it in the present day. We have already noted that the Strasbourg reformers had attempted to accommodate the weak by re-interpreting the significance of the elevation. Here Bucer believed that the significance of the elevation had always been idolatrous (i.e. sacrificial). By investing it with a new meaning (i.e. memorial of Christ's death), he could prepare the pcople for its eventual abolition. Even in this early period, however, he believed that the sacrificial vocabulary used in relation to the Eucharist had possessed a legitimate sense.

In Grund und Ursach, the sacrificial vocabulary used in patristic writing on the Eucharist was explained as a kind of apologetic-catechetical device, According to Bucer, the early fathers had no words which would allow them to explain Christian rites to the pagans in a language they would understand. Instead they had to draw on analogies from the pagan world. Thus Tertullian had compared Baptism to the ritual by which soldiers were received into the army ${ }^{110}$ For similar reasons, the "old Latin writers" (i.c. Tertullian, Cyprian "and others") had compared the

${ }^{110}$ See e.g. Tertullian, De corona 11 (PL 2:111-113). 
Eucharist to the sacrifices of the pagans:

... just as the pagans honoured their gods in their sacrifices, ate with one another and joyfully revived their friendship so it was that, on the basis that somcone who correctly observes Christ's Supper contemplates him with praise and thanksgiving, and on the basis that Christians renew their spiritual and everlasting covenant and testament in the Lord with holy food and drink, [the ancients] were able to say, "the pagans have their sacrifices and offerings in which they assemble to honour their gods. Our sacrifice will be the Supper of Christ in which we offer to God nothing other than ourselves, and yet consider there that sacrifice which was offered up for once for us and avails eternally..."11

In the same place Bucer compared early Christian use of eucharisticsacrificial vocabulary with the words of a Christmas hymn: "Christ is born roday." To spcak of the Eucharist as, "the sacrifice of Christ" was to express the immediacy of Christ's sacrifice for those who called it to mind and recognised that they had a share in its fruits. ${ }^{112}$ 'Thus the eucharistic-sacrificial vocabulary of the fathers was a figure of speech. It was a way of saying that Christ's sacrifice was present to faith. In the Eucharist, nothing other than the obedience of faith was offered to God in return.

\section{d The Traditional Scriptural Tcxts}

In Kurtzer wabrbaffiger Bericht Bucer considered the Catholic proof-text Malachi 1:11 as an example of how the Scripture was interpreted correctly when passage was compared with passage, and the whole submitted to the law of love from a pure heart, a good conscicncc and unfeigned faith (1 Tim 1:5). ${ }^{113}$ Treger and his ilk, wrote Bucer, read this passage as a reference to the Mass in order to prove that it was a sacrifice as they understood it. However a comparison with the spiritual sacrifices referred to in Romans 12:1, 1 Peter 2:5, Psalm 50:8 and Psalm 51:17 demonstrated that the prophecy referred to, "the preaching of the Gospel and of faith... not just in the churches on pretended altars, but in all places under his dominion..." So far this is standard Relormation fare. ${ }^{114}$ Bucer, however, went lurther. 'The sacrifice prophesied by Malachi was one of thanksgiving and praise,

${ }^{111}$ Grand und Ursach (BDS 1:216-217).

${ }^{112}$ Tbid., 216. See also BDS 2:110. Despite the similiarity to the Easter (i.e. "Christ is risen today") analogy used in Zwingli, De canone (See above, ch. 4., p. 63) it possibly came to Bucer via Capito's An den bochroürdigen fürsten und berren Weilhelmen Bischoffen zu Strulßurg wnnd Landgrawen zu Elsats Entschuldigung... (Strasbourg: W. Köplcl, 1523) D2a-b; quotcd in Kauffman, 139, ‥ 139.

${ }^{113}$ BDS 2:59. (ff Erasmus, Retio (LB 5:135B).

${ }^{114}$ In Grund and Ursach (BDS 1:217). 
but it was also an acceptable food offering in so far as Christians put away the old yeast of wickedness and became the new unleavened dough of purity and truth (1 Cor 5:7-8). As far as I can discover, Bucer is the only one of the Reformers to have accepted that the oblatio munda of Malachi 1:11 was a cereal-offering as well as one of praise and thanksgiving. Here he seems to have wanted to keep a back-door open to a eucharistic, even a eucharistic-sacrificial interpretation of Malachi 1:11, provided that the sacrificial connotations here were divested of any notion that the Euchurist was an offering of the body and blood of Christ performed by a "tonsured and anointed" priesthood. ${ }^{1 i 5}$

Bucer was, however, unwilling to concede (as Zwingli had done in De canone missae epicheiresis) that the external ritual of the Mass could be seen as a liturgical allegory corresponding to this figurative language of sacrifice and offering. ${ }^{16}$ In Grund und Ursach Bucer followed Zwingli's De canone missue libelli apologia (1523) in ruling out the legitimacy of such allegorical interpretations. ${ }^{17}$ Some, he wrote, wished to explain the words and works of Christ by recourse to the types and shadows of the Old Testament (e.g. the use of gestures, vestments, altars and the title "priest"), but when one had beheld the countenance of Christ in whom the law and prophets were fulfilled, it was perverse to wish to return to veiled countenance of Moses (cf. 2 Cor 3:12-18). ${ }^{118}$

In his John commentary, Bucer availed himself of the opportunity provided by the type of the brazen serpent (John 3:14) to criticise the exuberant use of allegory which he found in the exegetical writing of the fathers, and to lay down guidelines for its legitimate usc. ${ }^{119}$ Typological interpretation of the Old Testament should be governed by the typology used in the New. For examplc, Melchizedek could be regarded as a type of Christ in terms consistent with Hebrews 7. Thus Christ was the true king of justice and peace, the true priest and the one who had truly blessed Abraham and his descendants. Bucer did not attempt to dismiss patristic eucharistic typology here. He did not need to, because it is clear that such typology would fall under the sentence passed a few paragraphs later:

${ }^{115}$ Kurtker wabrhafftiger Bericht (BDS 2:61), "... darzu auch das speißopffer. dann wir cin newer teyg sein sollen, gleich wie wir ungeseürt seind, i. Corinth. v. Das ist: zuom gefallen Gottcs sollen wir leben on alten saurteyg der boßheit und argkeit un in dem syeßtag der lauterkeit und worheit. Diße exposition lemen uns andere ort der schrifft und reimpt sich etwas bassz uff die liebe uß lauterem hertzen etc. dann wir mit eüch sagen solten, wir beschornen und gesalbten kitinnen allein Christum für alle sachen upoferen." Discussing various kinds of sacrifice in S. psolmormm, $110 \mathrm{a}-\mathrm{b}$ he also refers to the minchab of Mal 1.11 as "oblatio cibaria."

${ }^{116}$ CR 89:600-601.

${ }^{117} \mathrm{CR}$ 89:620. Here Zwingli explains that vestments had been tolexated only for the sake of the weak.

${ }^{119}$ BDS 1:253. See also ibid., 234 235.

${ }_{119}$ In Evangelion Ioannis 3, sect. 2 (BOL 2:142-157). On Buccr's wider treatment of allegory, see Müller, Martin Bucers Hermeneutik, 100-114. 
If you wish to refer to a type what you attribute to Christ and his body, and the writings of the apostles do not teach it, and the Holy Spirit has not revealed it as a certainty to his saints, you will teach nothing sound and you will hear that common saying: "a figure proves nothing." 120

In his Psalms commentary (i.e. on Ps. 110:4) Bucer wrote that those who found a type of Christ's priesthood in Melchizedek's offering of bread and wine had written inconsyderate. No such type was warranted in the New Testament. Nevertheless, like Zwingli he allowed that Melchizedek had "offered" (proferre) bread and wine to Abraham and his soldiers. ${ }^{121}$ One might therefore retain the eucharistic typology if one were to say that:

Just as Melchizedek offered bread and wine to Abraham when he was tired from battle and to his men; just as he revived them in this way and prayed well, so Christ gives his people the living and life-giving bread and winc from heaven, namely his flesh and blood, and by this he restores their strength so that they may rejoice forever... ${ }^{122}$

However, those who wished to indulge in "allegories," should follow the example of the apostles who, under the influence of the Holy Spirit, preached a Christ they had seen face to face. Except when confronted by those who were "addicted to gesture and ceremonies," they did not attempt to expound the mystical significations of rites, nor did they pass such interpretations on to their successors. Paul, for example, had used typology only sparingly when pressed to it by pseudoapostles who urged the necessity of the ceremonial law and descent from Abraham, to the detriment of the grace of Christ. ${ }^{123}$ The phrase "addicted to ceremonies" used here was precisely that which Bucer would use in the 1530s to dcscribe the "weak" Christians under the yoke of Anti-Christ.

In Bucer's writing in the late 1520 s we find him acknowledging that the Eucharist had succeeded the multiple sacrifices of both the Jews and the gentiles. ${ }^{124}$ Like Baptism, the Eucharist fulfilled these types in so far as it was: "a symbol and

\section{I.XX.}

${ }^{123} \mathrm{BOL} 2: 154$.

${ }^{21}$ Zwingli, Christliche Antreort (CR 90:189) notes proferens in the Vulgate and exenenken in

${ }^{122}$ S. psalmoram, 343a, "Rectius hunc typum explicarcnt isti, si dicerent, sicut Melchizedek, fesso a praelio Abrahamo, $8 \mathrm{C}$ suis panem \& uinum protulit, quo cos recrcaret, \& bene precatus est, ita Christum suis dare panem \& uinum de coclo uiuum ac uiuficantcm, nempe carnem $8 c$ sanguinem sutm, quo ita vires reficiuntur, ut acternum gaudeant..."

${ }^{123}$ In Evangelion Toannis 3, sect. 2 (BOL 2;153).

${ }^{12+}$ See e.g. Epistola apologetica (BOL 1:94), "In Eucharistia quae una in vicem successit tot tanque multipliciun sacrificiorum sicut baptismus in locum toties repetendac olim ab aqua expiationis..."; In quatuor evangelid, 186a; S. psalmorum, 145b, "Nos in locum omnium sacrificiorum, unam habemus Fucharistiam..," (re. Ps. 26:6-8) 
token of the covenant which God has made with us [by which] we are reminded of those things which it befits God to do for us and us, in turn, to do for God." ${ }^{125}$ The relationship between the sacrifices and ceremonies of the Old Testament and the Eucharist was explored in greater detail in Bucer's Commentary on the synoptic Gospels and in his Psalms commentary. In his discussion of the institution of the Supper, Bucer wrote that every commendation of God's kindness and every confession of faith in God among his saints was accompanied by a symbol. God had initiated his covenant with circumcision, confirmed it with sacrifices, and conferred higher offices by means of the imposition of hands and anointing. Each of these symbolic actions prefigured Christ. Even though the Gentiles were not aware of the nystical significance of their own sacrifices, Nature had at least prepared them for the Gospel with the expectation that in all serious transactions words would be accompanied by a sign. ${ }^{126}$

Here the apologetic-catechetical use of sacrificial vocabulary which Bucer found in Tertullian and Cyprian was implicitly legitimised. The two Latin fathers were teaching the gentiles in a language they had been prepared for by the lex naturae. Bucer seems to have envisaged a progression rather than a radical disjunction between the sacrifices of natural religion or the law of Moses and the sacraments of the New Testament. The broken bread and the cup, for example, fulfilled the type of the libation found both annong the gentiles and the Jews. ${ }^{127}$ Bucer also noted the occurrence of two cups in Luke's account (Luke 22:17 \& 20) of the institution of the Eucharist The first cup, he wrote, did not belong to "our sacrament," but to the old law. Christ, however, had observed this libation, because he zealously performed any rite which could be accommodated to human piety. Bucer claimed that Jews had blessed a cup at the beginning of a meal in order, "that they might always take food and drink in the presence of the Lord, as it were, from his hand, and in order that they might live completely for God by whom they acknowledged and declared that they were kindly nourished." 128 At the end of the Supper Christ established a blessing cup with which thanks was given for a gift surpassing that of bodily food or drink: i.e. for our redemption won through this blood. With the cup of blessing Christians were taught to proclaim not merely the

${ }^{125}$ Fpistola apologetica (BOI. 1:94).

${ }^{125}$ In quatuor evangelia, $184 \mathrm{a}$.

${ }^{127}$ Thid., 184b, "Sic enim est \& Baptismatis symbolum, quo non apud Tudaeos tantum, sed apud omnes gentes initiatio ad religionem \& omnem religiosan actionem fiebat. Vt itaque libatio panis \& vini in omni vsu sacrificiorum apud omnes gentes erat, res quoque tam simplex \& parabilis, Dominus cam sanctificare voluit, \& Ecclesiae suae sacramentum facere, quo veram veri corporis $8 x$ sanguinis sui communionem suis impertiret."

${ }^{128}$ Thid., 184a, “...vt illi semper velut coran Domino, \& ex illius manu cibum potumque sumerent, indeque prouocarentur, vt Deo etiam toti viuerent, a quo se adeo benigne ali agnoscebant, atque praedicabant." 
kindness of God in supporting their bodily lives, but in bringing them from eternal death to eternal life. ${ }^{129}$

For Luther and for Melanchthon, sacrament and sacrifice stood opposed. For Bucer, as for the Swiss Reformers, sacrament and sactifice fell into the larger category of divinely instituted signs or "ceremonies" of the covenant, reminding us of what we can expect of God and what God requires of us. Both sactament and sacrifice pointed toward Christ. Under the law of Moses the ceremonies had a future reference. Under the New Testament they commenorated Christ. Bucer would not say that the Eucharist was a sacrifice because for him this would have been tantamount to saying that the Eucharist was instituted as an offering of the body and blood of Christ. Yet all ceremonies and institutions from Abraham to the time of the apostles, "were divinely given so that the saints might be conformed to the law of God, that is that they might love God with their wholc heart, and love their neighbour as themselves." 130 In his Psalms commentary Bucer cautiously readmitted the notion of sacramental "repetition" on the basis that the ceremonies of both Testaments found their unity in the unique sacrificial work of Christ.

One is the blood of Christ which makes expiation for our offences and reconcilcs us to the Father (Hebrews 9:[12]). For this we, too, give solemn thanks in the sacred Eucharist, and with our commemoration and thanksgiving we, as it werc, repeat it. For thus we read in [the Decretum Gratiani]...: Whon the host is broken, while the blood is poured from the chalice into the mouths of the faithful, what else is depicted but the immolation of the Lord's body on the cross, and the stream of blood from his side. It is for this rcason that Saint Thomas writcs that the Eucharist is called a sacrifice by reason of what is past, in so far as the Lord's passion, which is the true sacrifice, is conmemorated there. ${ }^{131}$

${ }^{129}$ In quatuor evangelia, 184a, "Idque item ex more vetusto Iudaeorum, sed quen vertit hic in sacramentum sui noui populi. Poculum enim libabat is qui peracto conuitio Deo gratias agrebat. Inde memorant Euangelistac Dominum iterum gratias egisse. Instituit autem vsum huius poculi nobis, ad agendum gratias ob longe praestantius donum quam sir cibus $\&$ potus corporis, pro redemptione nostri sanguine ipsius facta. Et hinc vocat illud Apostolus [1 Cor 10:16] poculum benedictionis, id est gratiarum actionis quod benedicimus, id est circa quod, vel quod habentes in manibus (vt D. Chrysostomus istuc Apostoli dictum interpretatur) benedicinus Domino, \& praedicamus beneficium quod sanguine suo non ab aeterna morte asseruit in vitam acternam. $\mathrm{CF}$. Chrysostom, In 1 Epistolam ad Corinthios (PG 61:199).

${ }^{150}$ S psalmonm, 145b, "Omnia utique instituta $8 x$ caerentoniac ad id diutinitus datas sunt, ut: sancti tandem legi Dei conformurentur, hoc est, diligerent Deum ex toto corde, \& proximum sicut se ipsum."

${ }^{131}$ S. psalmonm, 38a, "Vnus est sanguis CHRISTI, qui commissa nostra expiat, \& nos patri reconciliat, Hebrae. 9. Pro hoc $\&$ nos in sacra Euchariscia sollennes agimus gratias, ac idem pia commemoratione, et gratiartm actione, velut repetimus. Sic enim legimns de Con. distin. 2. cap. Cum frangitur [c. 37]. Cum frangitur hostia, dum sanguis de cilice in ora fidclium funditur, quid aliud, quam Dominici corporis in cruce immotatis, ciusque sanguinis de latere effusio designatur? 
As Bucer noted in his Commentary on the synoptic Gospels, one of the reasons for this "repetition" was that, "while we live here, therc is never a full communion with Christ and his life (for he is ncver everything in us, nor we everything in him). 'I'hus we truust always seek and desire that he live tnore and more in us and we in him." "The "repetition" was no mere memorial, but the means through which the faithful grew with their brothers and sisters into the one bread and the one body. ${ }^{133}$

However, even if the Eucharist belonged to the same genus as the sacrifices of the Old Testament, the state of affairs obtaining after the death of Christ was different from that which had obtained before it. Under the New Testament there had been a richer and more cffective outpouring of the Spirit than there had been under the Old. Now the Spirit worked more from within than through external ceremonies. For this reason there were fewer ceremonies of the Ncw Testament. Those who beheld God lace to face were completely free from all need for ceremonies and it followed that the closer one came to the full vision of God the smaller the need for external signs. ${ }^{134}$ It is interesting to note the progression in the Psalms commentary. It is no longer a case of Evangelical freedom pure and simple. Those who live under the New Testament are freer than those living under the Old Testament, but still not completely free. Only the blessed are completely free. ${ }^{135}$ The whole dispensation of ceremonies had a pedagogical function: the weaning of God's elect, across the course of human history, from the worship of creation to worship of the Creator. The multiple ceremonies of the law reflected the infancy of God's chosen people. Firstly, they set the chosen people apart from the gentiles and their idolatrous ceremonies. ${ }^{136}$ Secondly, they prevented the chosen people from

Vnde et $D$. Thomas parte. 3. quacstione. 73. Eucharistiam sacrificiun nitione eitus, quod praeterijt, uocari scripsit, quatenus in es paßio DOMINICA, quae uerum sacrificiun est, commemoratur." See Friedberg 1:1327 and ST 3a q.73 a.4. Passage discussed in De Kroon, "Bemerkungen Martin Bucers über das Abendmahl in seinem Psalmonlrommentar von 1529," in Bucer und seine Zeit, ed. De Kroon, 92-94.

${ }^{132}$ In quanor evangelia, 184a, "Vt uero nunquam dum hic vituinus, plena est in nobis ista communio Christi \& vita eius (nunquam enim est ille in nobis omnia, \& nos omnia in eo sumus) ita semper quaerendum \& expetendum notis est, vt ille magis nagisque sit in nobis, \& nobis in illo."

133 S. psalmorum, 38a, "... sic pia consideratione quod horum [i.e. sangtuis et corpus] immolatione in uitam aeternam restituti sunt, recreantur, \& amore seruatoris inardescunt, ut totos se illius uoluntati dedant, inque gratiam eius, cum fratribus uere in untm corpus, \& eundem panem coalescunt."

134 Ibid., 225a, "At ubi foedus nouum cum electis per uninersum orbem sparsis, per Fuangelion, \& huius persuasorem Spiritum sanctum largits, quam unquan antea super omnes elcctos effusum, ictum est, \& coeperunt plenius quam antea Deum cuncti agnoscere... ut propius ad uitam coelestem sancti accesserunt, ita elementis pietatis, externis huiusmodi cerimonijs [sic], facti sunt liberiores, sicut corum peritus liberi crunt, cum Deum uidebunt sicuti est.

${ }^{133}$ In Evangelion Iodnnis 3, sect. 2 (BOL 2:153), "... nos Spiritu ditiores sumus, acceptimus paucissimas, aliquas tamen, quia nondum toti spirituales sumus."

${ }^{136}$ S. psalmorum, 196a, 225a, "... quamdiu popuhus I)ei pueri instur habuit, \& a gentibus segregatus sub lege, ceu paedagogo degit." 
inventing ceremonies of their own and falling into idolatry. The complex rituals of the pontificals and monastic ordinals were evidence of this continuing human propensity. Thirdly, God made the burden of the ceremonial law insupportable (Acts 15:10) in order to tcach his people obedience. ${ }^{137}$ Fourthly, and most importantly, the sacrifices of the ceremonial law taught the chosen people to depend and trust in God rather than his creatures. The consequence of such trust was the sacrifice of rightcousness by which the elect were re-formed in the image of God, consecrating themselves to his glory and to the benefit of those with whom they lived. ${ }^{138}$

As the reference to the pontificals and monastic ordinals suggcsts, even the ceremonies of the New Testament also continued to fulfil their pedagogical function under the New Testament. The tandem which Bucer had used to describe God's purpose in instituting ceremonies across the course of human history, also applied to the individual's growth in holiness. 'T'o be reconformed in holiness was a gradual process. Thus the two ceremonies of the New Testament set the elect apart, and showed them that God wished to be worshipped through the obediencc of faith rather than through the superstitious observance of ceremonies. To remain attached to outward signs was at worst idolatrous and at best childish. The adult form of life was to become conformed to Christ and God, so that one's every word deed, in every time and place were dirccted to God's glory and human salvation. ${ }^{39}$

\subsection{Continuity between Bucer's Earlier and Later Approach}

It might not appear that the sacramental theology of Bucer's scriptural commentaries left any more roon for ceremonies not expressly enjoined in Scripture than did the principles enunciated in Grund und Ursach, but I think in fact they did. Firstly, in his discussion of Matthew 26:26-29, he inplicitly legitimised the later inclusion of elements not originally included in the Supper. Jesus had cstablished a solemn ceremony:

by which, in the place of all the sacrifices and ceremonies of the ancients, we might nourish our faith and renew all devotion. Hence this ceremony has becn celebrated by all the saints right from the time

${ }^{137}$ BOL 2:152-153.

${ }^{134}$ S. psalmonm, 37b-38a, " $\mathrm{E}$ igo in alia animo inclinare, $8 *$ a creattris sta bona quaerere, radix, fons, \& fundamentum est omnis iniusticiae. Quis iam det Dei \& potentiam \& bonitatem, tum hominum ac omnium retun extra Deum inanitatem \& fugacitatem satis agnouisse? cui enim hoc datum est, ei haudquaquam poßibile est, non in Deo solo fiduciarn omnem collocare, \& prae to cuncta pro nihilo ducere, indeque ad Dei inaginem penitus reformari."

139 Ibid., 225b, "Puerilia autem esse elementa, quicquid est corporalium rituum, \& externatum caeremoniartum, nems dubitare poterit, qui agnoterit virilem vitae formam essc, ut Christo atque adeo Deo conformes simus, ita comparati atque instructi, ut ounia dicta \& facta nostra, omni tcmpore et loco, Deo gloriae, \& mortalibus sunt saluti. ${ }^{n}$ 
of the apostles to the present day with the preaching of the death of the Lord and the whole work of our redemption, with the prayers adjoined to this, and a collection for the poor..$^{140}$

According to Bucer's Psalms commentary, almsgiving belonged by its very nature to true sacrifice. ${ }^{141}$ Almsgiving was perhaps even implicit in the logic of the first cup of the Last Supper, with which the people of the Old Testament had been accustomed to acknowledge God as the source of their bodily sustenance. Almsgiving, however, was not explicitly mentioned in the account of the institution. In Bucer's comment on the institution narrative here, I believe we have a hint of a theme which he would pursuc in the early 1530s: the right of the church to institute practices, without explicit warrant in scripture, where these were conducive to the building-up of the body of Christ. Provided that it met this criterion, there was much that could be included in the eucharistic rite without express warrant in Scripture.

Secondly, Bucer's trcatment of the typology and economy of ceremonial law in his scriptural commentaries seems to me to foreshadow the gradualist policy which he would adopt toward the traditional eucharistic rite in the 1530s. The gradual unfolding of a ceremonial economy did not simply apply to the course of the history of the elect from Abraham to the present. If was also mirrored in the history of the individual member of Christ's body. Love of the creator above creation did not come all at once. Individuals had remained built on the foundation of Christ even whilc lapsing into the gravest idolatry. In his dealings with the Christian Judaisers, Paul provided an example of how such weak believers were to be dcalt with. He had become all things to each in order to draw some to a fuller recognition of the truth. Where necessary he and the orher apostles had appealed to the types and shadows of the Old Law to do this. Tertullian and Cyprian had likewise accommodated their language to that of the gentiles to explain Christian ceremonies in a language with which they were familiar. Such gradualism was justified in the economy of ceremonies itself. There was no fundamental discontinuity between the ceremonies of naturc and the Law and those of the New Testamcnt. Rather Baptism and the Eucharist were one further step in a process in which the Spirit was liberating fallen humanity from its desire to worship creation

${ }^{140} \mathrm{Jn}$ quatuor evangelia, 186a "...qua loco omnium sacrificiorum \& ceremoniarutm veterum, fidem nostram alerenus, \& pictaten omnem instauraremus. Finc cum praedicatione mortis Domini \& totius operis nostrae redemptionis, adiunctis precibus, \& collatione in partperes, celebratur haec ccrcmonia a sanctis, iam inde a tempore Apostolorum."

1"1 S. psalnorum, 38a, "Hoc si primum fecerimus holocaustum [i.e. corporum nostrorum], tum \& munera offerimus, sacras elcemosinas, \& quotidiana quolibet officia, quibus hostijs, ut Fpistola ad Ebraeos habet, gratificamur Deo, qui sibi factum interpretetur, quod minimis eis feccrimus." (re. the sacrifician institide of Ps. 4:6) 
and drawing it toward a free and unmediated vision of its Creator. We are all liberiores in the process of becotning penitus liberi. 


\section{BUCER'S PREPARATIONS FOR A COUNCIL (1534-1540)}

\subsection{Introduction}

In August 1530, during the negotiations of the Committee of the Fourteen at the Diet of Augusburg, Johannes Eck sent a memo to Melanchthon:

As to what you say on the application of the Mass and the opus operatum, I am for my part so certain of these that I would die for them. Yet for love of peace, I advise all the Estates now to keep silent on this matter until the coming council... In this way there will be peace and tranquillity and may the sword descend upon the Turk. ${ }^{1}$

Eck's words offer an excellent summary of the situation of the debate on the Mass in the period between Augsburg and the recess of the Diet of Regensburg in July $1541 .^{2}$ Since 1523 the Estates of the Empire had called for a "free Christian council" as a means of resolving the cansa Lutheri and as a rallying-point against the Turks. A general council was eventually convoked by Paul III in 1536, but its first session would not meet until 1545. In the meanwhile, individual Catholic princes instituted unilateral programmes of reform in their own territories in order to stem the progress of the Reformation.

In the Recess of Augsburg, Charles $\mathrm{V}$ admitted that many abuses and hardships had arisen in the church and promised to secure the convocation of a general council within a year. In the meanwhile, however, he ordered the Evangelical territories to return to the, "ancient Christian faith." Among other things, he forbade all modifications to either the private or public Mass. "Those cities and princes who failed to observe the terms of the Recess, were thrcatened with legal and military action. ${ }^{3}$ Charles' ability to act on these threats was hampered by the formation of the League of Schmalkalden and by the diplomacy of Francis I, whose contincntal European territories were flanked by those of the Hapsburgs. From 1534, Francis I made overtures to the Schmalkaldic Lengue and the anti-Hapshurg Catholic princes of Germany. In 1536 he concluded an alliance with the Ottomans. This foreign threat and the threat of civil war between the Lcagues of Schmalkalden and Nuremberg (formed by Catholic princes in 1538) made Charles V's need for a religious settlement all the more acute. At the Diet of

'Schirrmacher, Brief und Acten zu der Geschicbte des Religionsgespräcbes zu Marburg 1529 und des Reichstages zu Augsuturg 1530 (Gotha, 1876), 244, "Was meinet ihr, de applicatione missate und opere operato halt ichs bey mir so gewif, das ich drauf sterben wolt. Aber pro amore pacis rathe ich allen stenden, diß itzt in ruhe zu stellen, usque ad futuram concilitum... Sic fiet bona pax et cranquillitas et ueniat gladies stiper Titram."

${ }^{2}$ For the following sce, Jedin 1:166-415.

${ }^{3}$ Schirrmacher, 313 -314, 334. 
Frankfurt in 1539, he promised the Schmalkaldic League a colloquy, to be attended by all the princes and Estates of Germany. At it a select group of devout and irenic negotiators from both sides would atterxpe to find a way of ending the religious divisions. At Hagenau and Worms in 1540, and then again in Regensburg in 1541, Charles sought to implement this proposal.

This period saw a change in Bucer's attitude toward the Mass and the traditional church. The bulk of his activity in this respect came at the end of the period. Chapter Eight will examine the common statements on the Mass which emerged from the second Colloquy of Leipzig in 1539 and the secret Colloquy of Worms in 1540 . The focus of our attention there will be the statement on the Mass in the Worms-Regensburg Book which emerged from the latter colloquy. Before we do this, however, it will pay us to examine the development of Bucer's broader approach toward the traditional church and some of the factors which influenced it.

\subsection{Evolution of the Idea of a Religious Colloquy}

In 1533 Erasmus published De sarcienda ecclesiae concordia, a commentary on Psalm $83(\mathrm{LXX})$ to which he appended his proposals for the restoration of unity in the church (pending the decision of the promised general council). ${ }^{4}$ The work attracted a wide audience. At Strasbourg it was translated into German by Bucer's colleague Capito.' Bucer himself hoped that the German nation would take account of what Erasmus had written; they had much to thank him for. ${ }^{6}$ The governing principle of the recommendations in De sarcienda was synkatabasis or "accommodation." As we have seen, Christ's accommodation of his simple philosophy to all manner and condition of people had formed the model for Erasmus' theologia vera in 1519. So in De sarcienda divine synkatabasis, provided a model for the resolution of the ills the contemporary church. ${ }^{7}$ Christ had accommodated himself to the human condition in order to draw all humans to things more perfect. Likewise, it would behove those on all sides to accommodate themselves to the weakness of their neighbours. ${ }^{8}$ Erasmus reminded his readers that

+ Title of 1533 Froben ed. In the 1540 Froben edition \& LB, entitled De amabili ccclesiac concordis. For an account of the less than amiable circutnstances of its composition see Pollet, "Origine et structure du 'De sarcienda ecclesine concordia' (1533) d'Érasmc," in Scrininn Erasmianum, ed., J. Coppens, (Leiden, 1969), 2:183-188.

${ }^{5}$ Von der kirchen lieblicben vereinigkng (Strasbourg, 1533). Summary of dedication to Albrecht of Brandenburg at tached in Millet, Correspondance, 173, no 156. The translation attracted criticism from Gereon Sailer who feared it would encourage complaccncy anzong magistrates sympathetic to the Reformation (see ibid. 175).

6 To Ambrosius Blaurer, 8.1.1534, (Schiess 1:461, no. 39C) sce also ibid., 452, no. 385.

${ }^{7} \mathrm{LB}$ 5:486A-B, 498A.

${ }^{8}$ Ibid., 500B, "Accedat illia atrykaraßáous, vt vtraque pars alteri sese nonnihil accommodet, sine qua nulla constat, concordia. Sed hactenus obsecundetur, vt ne moueantur t'a 'ukiv hactenus feratur hominum infirmitas, vt paulatim inuitentur ad perfectiora." 
the kingdom of God was found within. Thus it was perilous to make judgements on the basis of outward appearanccs. ${ }^{9}$ For example, though idolatry was a grave sin, the statue of a saint might also be kissed out of love for the saint it represented. ${ }^{10}$ Harmony would return to the church as soon as individuals ceased to cast a censorious eye over the outward behaviour of others, and sought to live justly in accordance with the state of life allotted them. ${ }^{11}$ Imitation of the divine humility would also lead to respect for the proper limitations of theology. The divine mysteries greatly exceeded the human mind, and those who attcmpted to know more about them than God was prepared to disclose risked falling into madness. ${ }^{12}$ Where Scripture was paradoxical it should be allowed to remain paradoxical. Erasmus placed contemporary disputes over justification in this category. ${ }^{13}$ A conning council might decide on these matters, but until it did, it would be rash to abandon what had been handed on through the authority of the past, and confirmed by long use and historical consensus. Innovation was to be avoided absolutely unless it offered some signal benefit or one was driven to it by necessity. ${ }^{14}$

A few years earlier, in Contra psetdo-evangelicos (1529) Erasmus had launched an attack against Evangelical "innovations." Their illegitimacy, he thought, could be seen in the fruits they had borne. Far from encouraging amendment of life they had provoked a deterioration of behaviour both among the Evangelical laity and among the "monks" whose familiar savagery was now redoubled. This was a consequence of the rash haste with which the Evangelicals had dismantled the structures and rites of the traditional church. Erasmus repeated the familiar charge of Catholic apologetic: that the Reformers' attempt to restorc the church to its pristine state assumed that the church had done without Christ for fourteen-hundred years, and, "while her husband lay snoring," had worshipped idols, in entire ignorance of the content of Scripture. ${ }^{15}$ While he admitted that there was much that was in need of reform, Erasmus urged caution and moderation. Where reform was undertaken hastily, there was a danger that the baby would be thrown out with the bath-water: vitia rerum tollantur, non res ipsae. ${ }^{16}$

In 1530 Bucer published a reply: Fpistola apologetica. He argued that the consensus ecclesiae, could not be equated simply with uniformity in the church's

\footnotetext{
"Ibid., 484D.

${ }^{10}$ Ibici., 501A-F.

${ }^{11}$ lbid., 498A, 499F.

${ }^{12}$ Ibid, $480 \mathrm{~B}$.

Ibid., 500B-F.

${ }^{14}$ Ibid., 500B.

${ }^{15}$ LB $10: 1582$ E.

${ }^{16}$ Ibid., $1583 \mathrm{~F}$.
} 
legislation and liturgy. Such consensus had not even existed in the apostolic church (e.g. regarding the observance of the Jewish law). Bucer challenged Erasmus to identify even one subsequent father, council or Pope who had not differed from the others on many questions. ${ }^{17}$ The genuine consensus of the church was more fundamental. It amounted to faith in Christ and love of one's neighbour in which the whole of the law was contained. Bucer asserted that in all their reforms the Philoevangelici had attempted to vindicate such a consensus, and that they wcre prepared - particularly for the sake of the wcaker brethren - to leave intact a great number of the traditional institutions and ceremonies where this consensus could be preserved. ${ }^{13}$ Erasmus should not, however, assume that the preservation and restoration of apostolic teaching would always be associated with concord. Wherever the Gospcl was preached, there would always be discord, as Christ himself had testified (Luke 12:49; Matt 10:34-36). ${ }^{19}$ Here we notice a modification of the principles which had governed the liturgical reforms at Strassburg in the early 1520s. Freedom no longer meant anly freedom to abolish ceremonies without express scriptural warrant, but the freedom to preserve them as well. Where the doctrine of justification (as Bucer understood ir) was recognised as the foundation of the consensus ecclesiae, both liturgical conservatism and diversity were possible.

As its title suggests, the tone of the Epistola apologetica was defensive. In 1534, Bucer published the nore irenic Furbereytung zum Concilio. Significantly, this took the form of a dialogue. Its speakers are Gotpraecht ("one who still clings to the pomp of ceremonies, yet seeks God and his ways in truth") and Gothertz ("one of those who are called 'Lutherans', yet also seeks God with his heart"). ${ }^{20}$ Each asks the other to put anger aside so that he may speak freely from the heart. Gotprecht is a spokesman for the kind of anxieties aired by Erasmus in Contra psendo. evangelicos: acknowledgement of the need for reform; but distress at the uprooting of the church's traditions, and horror at the consequent unrest and moral decline. He represents Bucer's growing conviction, that much traditionalist opposition to Evangelical reform was a matter of addiction to antiquity and the fear of innovation rather than one of fundamental opposition to Evangelical doctrine. ${ }^{21}$

\footnotetext{
${ }^{17}$ BOL $1: 136-137$

${ }^{13}$ Ibid., 158-159, 207, 210, 219.

"I Ibid., 203.

${ }^{26}$ BDS 5:276.
}

${ }^{21}$ In Epistola apologetica (BOL 1:208) potentially sympathetic Catholics are described dismissively as "qui preposteris cerimoniis inhaerent." A more nuanced account came thirteen years later in De vera ecclesiarum in doctrina, caeremonijs \& disciplinat reconciliatione \& compositione (Strassburg: Wendelin Rihel, 1543) (Stupperich 73), 29-30, where Bucer classified the various types of Catholic adversaries: "Alij uero partim antiquitatis reterentia, \& timore nouitatis, partim amore ac studio eins doctrinae $\& \tau$ disciplinae, in qua educati sunt, \& ita prolecerunt ut aliquen locum teneant, partim etiam quod nostra agendi ratio, uidetur insolentior, socielatem nostram fugiunt. At 
The "Lutheran" Gotherz asserts that both sides of the religious divide harbour wolves in sheep's clothing, as well as true children of God. Any scurrilous behaviour on the Evangelical side springs from the flesh rather than from the Reformation itself. What is good brings forth only good (Matt. 12:33). Gotherz then attempts to demonstrate that the good on both sides are united on the essential articles (Hauptstück) of the Christian faith, even though they may differ with regard to certain outward ordinances and ceremonies. The two men enter a garden (where Gotherz says he keeps his Bible) to converse. Gotprecht compliments his collocutor on the state of this garden. Gotherz replies tellingly: "whon I tend my inner garden properly, then things are much better." 22

What Bucer had identificd as the substance of the consensus ecclesiae in the Epistola apologetica is advanced as the foundation of future unity between the two interlocutors: i.c. that true faith cannot help but be active in the works of love, and that faith without works is dead, and therefore no faith at all. Gotprecht notes that the Scholastics speals of fides informata which does not bring with it the love and deeds consequent upon the teaching of Christ. This is to be distinguished from the faith which hears the voice of Christ, holds what he says as certain and true, and demonstrates this in heart, word and work. Gotherz directs his companion (not lor the first time) to Eck's Encbiridion locorum commsnium which notes that, "according to the use of Scripture, belief in God (credere in Deum) includes cleaving to God through charity." The "Lutherans," he says, are speaking not of bare faith, but of fides formata. Wi Without such faith one is condemned, and yet God gives the gift as he pleases and cannot be compelled or questioned. ${ }^{24}$ On free will Gotherz claims that "we believe as Saint Augustine." In our fallen state wc cannot through our own free will turn to God and love him as our highest good (here he cites "Thomas and the Scholastics"). Yet, through the work of the Holy Spirit, God enables us to recognise him as our highest good, to love him and to wish to pleasc him. The will which chooses good through the operation of the Holy Spirit, is truly free in so far as it is unconstrained by a nature destroycd through sin. ${ }^{25}$ The notion of "faith active through love," permits the concepts of "merit" and works of "satisfaction" to make a return to the discussion of justification. Merit is admitted

hi, quoniarn Christi studio texentur, etiam si in multis praeter scientiam, non ita aduersantur nobis, quin plurima in administratione Ecclesiarum, quae iam aliquandiu [sic] obtinet, correcta uelint." Sce also Lenz $3: 21$.

${ }^{22}$ BDS 5:281, "Wann ich meins inneren gartens recht wartet, werc wol besser."

${ }^{23}$ Ibid., 288, 343. Cf. Eck, Encbiridion 5 (CCath 34:98).

${ }^{24}$ BDS 5:345

${ }_{25}^{25}$ Ibic., 344. Sce e.g. Augustine De spiritu et litera 5 (PL 44:201-205); De civitate Dei 15.21 (PL 41:466-467); Enchiridion 30-32 (PL 40:246 -247); Aquinas, ST 1 2ae q.109, a.1-8 \& 1a 2ae q.113 a.5; Biel, Collectorizm 2, dist. 28, q. 1 (Werbeck \& Hofmatın, 527-545). 
in the Augustinian sense: i.e. God crowns his good works in us. As Gotherz points out, even "your Eck" admits that merits are the gifts of God. ${ }^{26}$ Satisfaction is admitted in $s o$ far as it was once the name given by the ancient church to the works performed by penitents returning to the church as a disciplinary measure. It is to be understood, however, that these works do not satisfy God in the scnse that they placate him and bring remission of sins. This only Christ could do. ${ }^{27}$ Gother'z also rejects any notion of supererogatory works, the church's spiritual treasury and Purgatory. ${ }^{28}$

Belief in the possibility of agreement on justification would shape Buccr's policy throughout the period of the colloquies. The themes outlined above would be developed in greater dctail in his 1536 commentary on Romans, and their influence is apparent in the statements on justification which emerged from the colloquies of Leipzig, Worms and Regensburg. ${ }^{29}$ Bucer's understanding of human merit in particular, would play an important role in his interpretation of the Roman Canon's reference to the merits and prayers of the saints and his conditional acceptance of the Canon at the end of the period of the colloquies.

It is evident throughout the Furbereytung that Bucer continued to regard Scripture as both the final norm for the exercise of anthority in the church and the final criterion by which the validity of any external re-union between the churches of Christ was to be judged. At one point Gotherz remarks, "we wish to disdain noonc who otherwise teaches the truth. Yet must we not find and ascertain who is speaking the truth in divine matters from divine Scripture?"30 Gotherz refers to the fathers throughout as the "dear holy fathers," and, on most occasions, cites Aquinas favourably. It is clear, however, that these authorities are to be judged by Scripture.

'This might seem to bear out Peter Stephens' claim that, like the other Reformers, Bucer, "totally rejects setting the authority of the church beside or above that of the Bible." 31 Hammann, however, argues that in the early 1530s, Bucer was ready to set the authority of the ministry beside Scripture. The result is something akin to Oberman's "Tradition I." 32 Buccr's confrontation with the

\footnotetext{
${ }^{26}$ BDS 5:344-345. See e.g. Eck Enchiridion 31 (CCath 34:320); Augustinc, Epistola 194.5.19 "ad Sixtum" (PL 33:88); De gratia et libero arbitrio 6.9.15 (PL 44:890); Lombard, Sentences 2,27,7 (PL 192:715); ACA. 4.354 (BS 227).

${ }^{27}$ BDS 5:346.

${ }^{23}$ Ibid., 345.

${ }^{21}$ Conclusions summarised in prelace to Metaphrisis et enarratio in Epistolam D. Pauli Apostoli ad Romanos... (Basel: Petrus Perna, 1562) 12-14, (Stupperich 55a) (pagination same as 1536 edition).

${ }^{30} \mathrm{BDS} 5: 283$, "Wir woellen niemand verachten, der anders die warheyt sagct. Wor abor nun in Goettlichen sachen die warheyt sage, sollen wir nit dasselbige auß der gocttlichen schrifft suochen und lernen?"

${ }^{31}$ P. Stephens, The Holy Spirit in the Theology of Martin Bucer (Cambridge, 1970), 140.

${ }^{32} \mathrm{G}$. Hammann, 126.
} 
Strasbourg Anabaptists had led him to regard the visible church, its ministry and its sacraments as the habitual and normal (though not the exclusive) channels through which the Holy Spirit brought the elect into communion with Christ and worked out their sanctification. ${ }^{33}$ Thus, as Bucer observed in his Romans commentary, to ask whether the church had primacy over Scripture or vice versa was like the citizens of a commonwealth asking whether the laws given by the king had priority over the commonwealth or vice versa. In fact both had their authority from the king. Likewise if the king were to send out legates with his commands one would not ask whether the legates had priority over the commands or vice versa. Again, both had their authority from the king. The same was true of the church and its ministry, ${ }^{34}$

Thus, in the anti-Anabaptist Bericht auss der beyligen Geschrift (1534) Bucer defended unwritten laws (agrapba gebot) and noted that Tertullian, Cyprian, Augustine and Jerome, "and all those [whose writing] we possess" testified that the church had received unwritten ordinances from the apostles. ${ }^{35}$ Likewise, in the Furbereytung Gotherz readily admits that those who exercised authority in early church instituted practices without express scriptural warrant: e.g. the observance of Sunday, and rules concerning fasting and almugiving. These ordinances were of two kinds: those necessary for the Christian life, and those made to suit the exigencies of particular times and situations. As an example of the first, Gotherz cites the regulation of the Lord's Supper in 1 Corinthians 11 and the injunction in 2 Thessalonians 3:10 that those who refuse to work should not be given food. As an example of the second kind Gother's cites Paul's recommendation that women refrain from speaking and cover their heads in church (1 Cor 11:4-16; 14:34).$^{36}$ Both kinds were instituted to build up the body of Christ. Even where the second kind no longer serve their original purpose the present ministers of the church should not abolish them lightly lest they, "break the bruised reed or quench the dimly burning wick" (Isa 42:3). On the other hand, even the most solemnly enjoined commandments of God (e.g. keeping the Sabbath, honouring one's mother and father) could be broken when it served the human good and the honour of God (cf. Mark 2:23-28; Matt 19:29). Thus a certain equity or epieikeia was to be observed in the application or abolition of "laws which concern the outer man" - written or unwritten. One should always take into account time, place, and person in deciding the degree to which such a rule was to be observed. As Marijn de Kroon has

${ }^{35}$ Ibid., 115.

${ }^{34}$ Bucer, In Romanos, 18-19.

${ }^{35}$ BDS 5:225. The precise sententicie are not cited, but see below, ch. 9, p. $174 \mathrm{ff}$. See also, Müller, Mantin Bucers Hermeneutik, 162-165.

${ }^{36}$ BDS 5:312-317. Cl. Confessio Tetrapolitana 16 (BDS 3:107-109); Bericht (BDS 5:219-229) on Anabaptist use of Deut 4:2 and 13:1 against infant baptism.. 
remarked, the Aristotelian concept of epieikeia is Bucer's answer to Frasmus' synkatabasis. ${ }^{37}$

Gotprecht protests that some Evangelical preachers have abolished everything which does not have express warrant in Scripture - a fair description of the programme enunciated in Grund und Ursacb. Gotherz replies that the chief command and Word of God is that we should love the Iord with our whole heart, whole soul and love our neighbour as our sclf (Matt 22:37, 39); "all other ordinances and regulations which promote godliness are only explanations and interpretations of this law of love."3" In the Bericht, Bucer claimed that Christ taught only repentance and faith active in love and suffering. ${ }^{39}$ The apostles applied this teaching to particular situations even where they had no express command of Christ. In so far as Christ's ministers did the same, they could claim, (as had Paul, 1 Cor $7: 4 C ; 14: 37)$ to be acting on the azthority of the Holy Spirit. ${ }^{4 C .}$

This aspect of the authority of the church's ministry was not emphasised in the Furbereytung. It was perhaps something of which an audience of Gotprechts did not need to be persuaded. Nevertheless, Bucer emphasised there that the church, in so far as it was the assembly of genuine believers (and not simply the outward fellowship of word and sacrament) was the body, limbs and bride of Christ; the temple of the Holy Spirit. ${ }^{41}$ In so far as it regulated its life in a way that promoted faith active through love, it was to be heard as the pillar and bulwark of the truth (1 Tim 3:15). Whoever did not heed it was to be treated as a gentile or a tax-collector (Matt 18:17). ${ }^{42}$

Where did this place the church's unwritten tradition concerning the Mass? In the Bericht, Bucer sought to quell fears that admission of the unwritten tradition of infant Baptism would allow the readmission of the papist Mass. Unlike infant baptisn, he wrote, the Mass was not an authentic tradition of the church. Not only did it have no express or implicit warrant in Scripturc, but many aspects of it were expressly forbidden there. God had forbidden his people in bolh Testaments to

${ }^{37}$ M. de Kroon, Studien zu Martin Bucers Obrigkeitverständnis; Evangeliscbes Etbos und politisches Engugement (Gütersloh, 1984), 37-56. In the dedicatory epistle to Defensio adversus Axioma catbolicum, A2a, A5b, A6b, A8b Bucer appeals to the French goverment's exercisc of aequitas its matters of religion. See also Bucer, In Evangelion Iobannis 3, sect 2 (BOI, 2:150), Aristotle, Ethrics 5.10 and Aquinas, ST 2a 2ae q.20, "bonum est, praetermissis verbis legis, sequi id quod poscit iustitiae ratio et communis utilitas.

${ }^{38}$ BDS 5:318, "Nun, so das hauptgebot und wort Gottes ist, das wir sollen Got lieben a an $\beta$ gantzem bertzen, gantzer seelen und allen kreffen und den necbsten als uns sell... wer kan anders sagen, dann das alle dic ordnungen und satzungen, so zur Gotseligkeyt fürdcren, nur crklarung und auslegung seind dises gebots der licb."

\footnotetext{
"Ibid., 223.

${ }^{4 c}$ Ybid., 221 .

${ }^{41}$ Ibid., 291-29.3.

${ }^{42}$ Ibid., 293-295.
} 
trust in anyone but him, whereas in the Mass people trusted in the sacrifice of the priest. The Lord had said that "all" were to drink from the chalice, but in the Mass the chalice was withheld from the laity. The Canon whispered in Latin contraverned Paul's injunction that anything said in the Lord's Supper was to be intelligible (1 Cor 14:6-18). ${ }^{13}$ Thus in the Furbereytung, when Gotprecht asks how the Evangelicals can let such a long-held practice fall into abeyance, Gotherz responds with an impassioned denunciation of the Mass. He finishes: "My dear Gotprecht, I bey you, take it not amiss, but on this occasion I can no longer discuss this frightful abuse and unspeakable blasphemy against the passion of our Lord Jesus Christ and all Christian behaviour." "44

The dialogue is terminated, but only for the moment. It appears that Bucer had in mind another work in which Gotherz and Gotprecht would discuss the hard cases of Baptism and the Lord's Supper, ${ }^{45}$ 'I'his did not eventuate. Nevertheless, even in criticising the Mass, Gotherz has sketched in thc outline of a future dialogue. The Mass, he says, contradicts not only Scripture but all the, "dear, ancient, holy fathers." patristic writing on the Mass is thus not implicit, or at least fully implicit, in the present idolatry. Even the scholastics, Gotherz claims, did not believe that the Mass was a, "new offering of Christ for the living and the dead," as the simple folk were now led to believe. Rather they and the fathers called the Mass a sacrifice because it brought to mind the sacrifice of Christ on the cross, as well as the share we have in Christ who gives himself to the faithful in the sacrament. ${ }^{* 6}$

Here Bucer was simply reiterating the material which we have already noted in the Psalms commentary. The same approach was evident in two conciliatory works written at about the same time as the Furbereytung and, like the Psalms commentary, directed to the Gotprechts of the French court. The first was Bucer's Defensia adversus Axiona catholicum (1534). The second was a memorandum on the restoration of religious unity written for Francis $I$ in 1534.

Adversus Axioma catholicum was Bucer's response to an attack on the Reformation by the Sorbonnist Bishop of Avranches, Robert Ceneau. Bucer framed his discussion of the disputed questions in a way which highlighted the continuity between Evangelical doctrine and the patristic tradition. ${ }^{47}$ For a brief period in 1534

+3 Ibid., 226.

${ }^{44}$ Ibid., 351, "Mein Gotprnecht, ich bit dich, habe mirs nit zu unguot., ich kan von disen so crschrocklichen mißbreuchen und unaußprechlichen verlesterung des leydens unsers EIerren Jesu Christi und alles christlichen thuns uff diß mal nit mehr mit dir handeln..."

45 BDS 5:280, "Ire spacn vom Tauff und Sacrament seind so weit nun bracht, das wir davon zuo seiner gelegenheir besonders red haben muessen..."; 352, "... zu anderer zeyt wolten wir fruchtbarcr handeln..."

${ }_{40}^{4}$ Yhid., 350.

${ }^{*}$ See e.g. Lis prefacc (Adversus Axioma, B4b), "Nullum est in ecclesia receptum fidei toostrae symbolum, cui non in omnibus inhaereamus; deinde quae religionis nostrae dogmata nobis a Nicena 
and 1535, Francis I flirted with the idea of a teligious colloquy as a means of securing his desired alliance with the League of Schmalkalden and the Catholic princes of Bavaria. ${ }^{48}$ In the summer of 1534 , the Strasbourg physician Ulrich Geiger visited Wittenburg on behalf of Francis' envoy Guillaume du Bellay, and consulted with Melanchthon. He returned to France by way of Strasbourg and showed Bucer a memorandum which Melanchthon had composed for Du Bellay as well as a lettor which Melanchthon had written to Bucer himself. Bucer and Caspar Hedio wrote their owti memoranda on the restoration of unity. Bucer's memorandum acknowledged that agreement on the Mass would take considerable effort, but again appealed to "all the fathers" against opinions thrust upon the people, confirmed daily by the celebration of Masses, and condemned by the Scholastics themselves. ${ }^{49}$ The patristic material used in both these documents will be considered in the discussion of the Worns-Regensburg Book in Chapter Eight.

Another aspect of Bucer's policy toward the Mass is forshadowed at the end of the Furbereytung when Gotprecht asks how the two partics can ever have gentuine unity when they celebrate two different liturgies. Gotherz responds by appealing to the patristic church as a model of diversity in unity. He cites (but does not quote) Irenaeus's letter to Pope Victor I on the datc of Easter (quoted in Eusebius' Historia ecclesiastica 5.24), Augustine's Epistola 54 to Januarius on variation in eucharistic practice, and comments on variation in fast-days in the Historia tripartita $9.38 .^{50}$ As we shall see, Augustine's Epistola 54 would prove particularly useful to Bucer since it not only supported variations in eucharistic practice, but offered criteria for distinguishing between binding and non-binding traditions. Gotprecht objects that Christ cannot be divided, and that liturgical diversity will not work. Gotherz replies that, in this case, the two parties must work for a proper Christian council. If a general council is not forthcoming, a national council must be held. In this way Germany will set an example to other nations. ${ }^{51}$ At this point toleration of liturgical diversity is not extended to the

aliisque sacrosanctis synodis, illis vetustis, tradita sunt, item quae leguntur apud 'l'ertullianum, Cyprianum, Ambrosium, Hieronymum, Augustinum, Chrysostomum, Cyrillum, Nazianzenum et quicquid est maiorum gentium patrum; postremo etiatn quae isti viri Dei in sacras literas concorditer scripserunt, ecclesiae in en sententiam, imo Spiritus Satncti exponentes, hacc, inquan omnia sacrosancta habemus." I am indebted to my supervisor Dr. Ian Hazlett for access to drafts of his forthcoming edition in the Opera latinat series of Bucer's works. The memorndum, Sententiae Pbil. Melanchthonis, Martini Bacceri.. de pace Ecclesiae is edited in Poller, Études 2;509-520.

${ }^{48}$ Hazlerc, "Martin Bucer's Relationship with Trance," 516-518; Pollet, Étzdes 2:489-409.

${ }^{19}$ Pollet, Étzdes 2:5 12 .

so BDS 5:355. Sce PG 20:503; PL 33:199-204, 204-223; PL 69:1153-1156. Some of Augustine's Epistola 54 letter was reproduced in the Decretum Gratiani 1, dist.12, c.11-12 and 3 de consecr. dist.2, c.13 \& c.54 (Friedberg 1:29-30, 1318-1319, 1333-4) 'The use of this sententid in 1533 suggests that Bucer did not acquire it from Witzel as Fraenlkel suggests, BOL 3:143, n. 196.

${ }^{51}$ BDS 5:358. 
Roman rite. Gotherz exclaims that ceremonies which run counter to faith and good morals cannot be endured with patience. He cites the case of Nadab and $\Lambda$ biu who were consumed by fire for making an illicit offering of incense (Num 10:1-2). "Our God," says Gotherz, "is a terrible God and not to be trifled with."

By the end of this decade, however, Bucer's critique of the Roman ritc had softened. In Consilium theolgicam (c1540) Bucer would assure a Nicodemite vir quidam that, through diligent study of the fathers, the rites and ceremonies of the papal church could be adapted to a more wholesome interpretation: i.e. one which stirred up and strengthened faith and love. ${ }^{53}$ Bucer expressed his confidence that where the primacy of faith and love were maintained, "you can amply recover all Christians from the every abuse of any ccremony at all to its true use." ${ }^{54}$ At around the same time (from 1539) Bucer began to compile what would become an extensive, annotated anthology of patristic sententide on various disciplinary, ceremonial and doctrinal questions. ${ }^{55}$ We shall refer to this anthology, the Florilegium patristicum, in the course of Chapters Eight to Ten.

The precise circumstances addressed by the Consilizm theologicum are unclear. ${ }^{56}$ What is clear, is that Bucer had in mind the plight of Evangelicals, "living in churches as yet oppressed by the papal tyranny," and the extent to which they could participate in the liturgical and disciplinary life of the traditional church. ${ }^{57}$ The audience of the Consiliztm represents a different constituency from the Gotprechts of this world. Yet Buccr's purpose in advising against flight from the rites of the ungodly was to remind these crypto-Evangelicals of their duty toward their weaker brethren: i.e. those who had built on the foundation of Christ, and yet, because of their ignorance, had built in wood, hay or straw (1 Cor 3:11-12). ${ }^{58}$ 'This was borne out in the two passages which headed the first page of the

${ }_{52}$ Ibid., "Unser Got ist ein erschrccklicher Gott, mit dem nit zut scherzen ist."

${ }^{53} \mathrm{BOL} 4: 34-35$.

54 Ibid., 35, "Nam haec: esse in gratia, agere ex dilectione Dei, esse rite contritum et confessun, continent in sc veram idem, fideique verae ad omnia usum, ut vel his solis conditionibus possis Christianos abunde onnes a cuncto abusu quarumlibet ceremoniarum ad verum usum revecare."

55 On its dating see Fraenkel, "Introduction," BOL 3:xiv-xvi; \& " "Zwischen Altcatholicizismus und Cacsaropapismus: zu Martin Bucers Materialsammlung ïber die Rolle des Papsttums in der Alten Kirche," in Reformatio Eccleside, ed. R. Baïmer ([3aderborn, 1980), 597-598.

${ }^{56}$ Fraenlkel (BOL 4:xv-xxix) dates the work to the winter of 1540-1541, and believes that the last part of the work is intended to answer the anti-Nicodenzite argutnents of Calvin's Epistolde dute de rebus boc saecitlo cognitu apprime necessarisis (1537) (CR 33:233-312); P. Matheson, "Martyrdom or Mission? a Protestant Debate," ARG 8C (1989):154-171 dates the work to Sept.Oct. 1540 , and identifies the anti-Nicodemite adversary as Bullinger.

57 See the title (BOL 4:1): Consilitm theologicum in ctivadam viri gratiam privatim conscriptum quo autboritate sacrarum literarum ostendoret: an et quatenus Christiani, in ecclesits ponifficia tyranide adbuc pressis degentes, illkwon ritibus et peractionibus comunicare possint.

${ }^{58}$ Ibid., 5. 
Consilium. The first was 1 Corinthians 9:19-22 (...Cum liber essem ex omnibus, omnibus me servum feci, ut plures lucrifacerem). Bucer had appealed to this passage in Grund und Ursach when justifying the retention of the elevation. It was now redolent of Erasmian synkatabasis - or, rather, Bucerian epieikeia. The second passage came from Augustine's Epistola 54, cited, as we have seen, in the Furbereytung. For the sake of fellowship and the avoidance of scandal, it enjoined the preservation of local traditions where these were not contraty to the catholic faith or to good morals. ${ }^{59}$ Bucer continued to assert that Christ had nothing in common with Belial, but he reminded his reader that to remain in communion with the weak was to remain with members of Christ rather than Antichrist. ${ }^{60}$ There were still churches of Christ "anong the papists."

With regard to the traditional Mass, the Consilizm did not mince words:

there is no other instrument of ungodliness and superstition in this world today (nor was there ever any) which was observed by humans with greater contempt of God and Christ and morc serious ruination of godliness than the Mass. ${ }^{62}$

It was a product of the, "superstition and avarice of Antichrist." discussion of the Mass and associated practices (e.g. commemoration of the dead) the Consilium amounted to the dialogue on the Mass promised in the Furbereytung. Here Bucer outlined what a Gotherz might tell a Gotprecht in order to edify him in faith while leaving intact the majority of the "ceremonies" to which the latter remained attached. Moreover, Bucer would assure his reader that the deplorable wickedness and superstition of the Massing-priests and their retinue had no foundation in the traditions and decrees of the fathers, the words of the Mass itself or, indeed, the teaching of the schools. ${ }^{64}$ Again, we shall examine the material on which Bucer based this assertion below.

${ }^{5}$ Ibid, 1. See PL 33:200.

${ }^{6}$ BOL 4:173.

${ }^{61}$ Ibid., 5. Cf. Von der waren Seelsorge (1538) (BDS 7:95) "Dann nicht in ceremonien und eüsseren gepreüchers, sonder inn waren glauben, in gehorsame des reinen Evangelii, in rechtem brauch der h. Sacramenten, wie uns die der Herre [sic] verordnet hat, staht die gemeinschafft der christlichen Kirchen."

"2 BOL 4:94, "... ut hodie non sit in orbe instrumentum impietalis et superstitionis (nec unıquam fuerit) quod maiore contumelia Dei ac Christi ct graviore ruina omnis pietatis ab hominibus colatur, quam missa."

${ }^{63}$ Ibid., "Et primum de supremis et gravissimis abominationibus, quae superstitione et avaricia antichristi circa sacram eucharistiam invcctae sunt."

${ }^{i n}$ Ibid., 149. 


\section{CATHOLIC IRENIC WRITING ON THE SACRIFICE OF THE MASS (1530-1540)}

\subsection{Introduction}

What had caused this gradual change in Bucer's approach to the Mass? But for the acquisition of new patristic sententiae, the schema outlined in the Psalms commentary and in the Furbereytung would continue to inform Bucer's understanding of the eucharistic sacrifice. During the 1530s, however, there was a redoubled attempt by Catholic writers to "interpret" the Mass in a way which sought to minimise the oppositions which Luther had claimed to find berween the Mass and the doctrine of justification. This effort was largely, though not exclusively, the work of Catholic Erasmians.

\subsection{Augsburg 1530: the Committee of the Fourteen}

The possibility of "suitable" interpretations of the Mass had already been raised at the Dict of Augshurg. Toward the end of August 1530 Melanchthon wrote to Spalatin seeking his advice. It had bcen falsely reported, he wrote, that the Evangelical negotiators in the Committee of the Fourteen had acceded to a scries of articles urged on them by the Catholics. Among these was one which supported the retention of the Roman Canon subjcct to a "suitable and godly interpretation." The Mass, it said, was a memorial sacrifice, and the Canon's references to "victim" and "sacrificc" should be understood in this way. It seemed to Melanchthon, however, that to concede this would be to hand the Massing-priests the handle of a sword with which they could, in time, re-introduce their impostures. "What," he asked, "does the peasant know of a 'figurative,' 'passive' and 'representative' sacrifice?" It is difficult to identify the sources of this "interpretation," though one of them seems to have been Eck. In his Iudicium de Augustano confessione for Albrecht of Mainz and George of Saxony, Eck wrote that agreement on the words "sacrifice" and "victim" would be possible, "if they [i.e. the Evangelicals] did not deny that Christ was offercd figuratively in the Old Testament, in his suffering on the cross, and in mystery in the Mass, and that this mystical offering was the memorial of the victim offered on the cross."

${ }^{1}$ CR 2:296 (20/21.8.1530). For the Catholic proposal see Schirrmacher, 234 and the record of proceedings by Hieronymus Vehus, in Hunée, Der Libell des Hieronymus Vebus zum Autgsburger Reichstag, 1530: Untersuchung und Texte zur katholischen Concordid-Politik (Münster, 1988), 229-230.

${ }^{2}$ Indicimm doctoris Eccii de Augustana confessione (Schirrmacher, 207), "Concordari posset cum ecclesia, quod non esset uocanda encharistia, sacrificiun, uictima. Victima. Sic fuit in ara crucis. Si tamen non negarent, sic corpus Christi fuit oblatum in ueteri testamento figuraliter et in cruce passibiliter, ita in missa mistcrialiter. Quae misterialis oblatio esset memoria oblationis uictimalis in 
There seem, however, to have been other sources for the Catholic offer. As early as 1526 , Melanchthon alleged the existence of an "opinion" which sought to retain private masses, and to correct the earlier "opinion of Thomas and Scotus." He noted that proponents of the second opinion defined the Mass as a good work, though one which we present to God in order to give thanks rather than to deserve (promerere) grace for the living and the dead. They claimed that Christ had instituted the sacrament as thanksgivitug for his passion. They compared this to the Roman institution of games as a way of offering thanks to deserving citizens. Like the good work of almsgiving, thanksgiving benefited both the individual and the community as a whole. The daily celebration of Mass was to be prescrved, since, like the inge sacrificium of the Levitical law, it provided a ceremonial means by which thanks could be given on the community's behalf. ${ }^{3}$ Melanchthon described the authors of this new opinion as quidam recentiores. "Faber and the like" wcte said to favour it. ${ }^{4}$ In one of two similar Indicia de missa dating from 1530, Melanchthon described the proponents as auctores magni and noted that they were followed by many bishops. ${ }^{5}$ Erasmus, however, was not intended here. Melancthon attributed a fourth erroneous opinion to him: "that the Supper is a symposium, instituted for the nourishment of mutual love, because communal meals give rise to friendships..."

In one 1530 Indicium, Melanchthon wrote that if the second opinion had prevailcd, Luther might never have written against private Masses. ${ }^{7}$ With its emphasis on memorial and thanksgiving, however, this opinion still down-played the fact that Christ had instituted the Supper in order that we might receive something from him. As long as the private Mass was retained, onc was forced to conclude that the church's ministry had been established either to offer something to God or in order to receive Christ and his consolations for itself alone (i.e. in the

cruce." A nus. Compenditum confessionis protestantium principum (Honée, 281-293) (11/12.9.1530) did its best to accommodatc this language without accepting either the Canon or the private Mass.

${ }^{3}$ Melanchthon, Irdicium de missa et coclibatu (CR 1:840-841).

"Two "Fabers" had written on the Mass before 1526. Johannes Fabri's Mallezs, 4.2, (48b) mentions the Mass only in passing and not in an irenic veir. Jacques Lefèvre d'Etaples deals with the eucharistic sacrifice in: Quincuplex psalterium (Paris: in clarissino Parisionum Gymmasio, 1509), 6a (Ps. 4:6) 76a (Ps 49:15) 279a (Ps. 109) (all LXX); Pauli epistolae xim (Paris, [s.n.],1515) 146b-147b, $2.36 \mathrm{~b}$ (re. Hebrews) and his Commentarii initiatorii in quattuor evangelia (Basel: A Cratandri, 1523), $115 \mathrm{a}, 232 \mathrm{ab}, 239 \mathrm{a}, 256 \mathrm{~b}-257 \mathrm{a}$ (re. the institution accounts). The memorial charatter of the eucharistic sacrifice and its Paschial typology are emphasised but, with the exception of his Guspel conmentaries, these were published before 1520 and there is no evident sign that even the Gospel commentaries were offered as solutions to disagreements which had arisen over the Mass. (For other "Fabers" see Bietenholz 2:4-6, 315-318).

${ }^{5} \mathrm{CR} 2: 211$. hnother later version in Schirmacher, 153-162.

"Schirrmacher, 161. In CR 2:208--214 however, this fourth opinion and a fifth (of Zwingli) are onitited.

${ }^{7}$ Schirrmacher, 156; CR 2:211. 
priest's communion) - whatever thanksgiving the celebrant or non-communicant lay-person might offer in addition. Here already we find Melanchthon making the sharp distinction between sacrament and sacrifice which would appear in his Apologia. The "eucharistic" sacrifice of the faithful was rightly associated with the sacrament of the Lord's body and blood, but not of its essence. ${ }^{8}$ Melanchthon thought, neverthcless, that there was material here for a disputation inter erudilos. If such a disputation were not to take place, he asked that "in the meanwhile" at least, those who did not hold private Masses should not be condennned as heretics, for they did nothing against either Scripture or the custom of the ancient church. ${ }^{9}$

In fact the Catholics at Augsburg insisted on the retention of the private Mass, and the Evangelicals rcfused with equal intransigence to reintroduce the practice in their territories. ${ }^{10}$ The reason for their failure to reach even an interim modus vivendi on the private-Mass lay in one word: application. What, in other words, was the relationship between the sacrificial victim of Calvary present in the sacrament and the Canon's offerimus pro? Whose was the opus operatum, and in what way could it be said to "merit" anything for anyone? It might well be possible to explain the Canon's references to "victims," "offerings" and "sacrifices" by means of types, memorials, mysterics and "threefold" distinctions but, as Melanchthon wrote to Spalatin, the Canon's "we offer them for..." suggested a real sacrificial opus rather than just a memorial or representative one. ${ }^{11}$

Nevertheless, in the negotiations of 1530 we have the ground prepared for the colloquies in which Bucer was to participate between 1539 and 1541. The Catholics were rcady to cntertain interpretations of the Mass which sotight to allay Evangelical anxieties. The Apologia, for all its intransigence on the opus operatum, signalled those areas of the traditional vocabulary (i.e. thanksgiving, prayer for the dead, commemoration of the saints) which the Evangelicals were ready to admit.

\subsection{Erasmus}

As we have seen, Erasmus did not believe that the sacrificial character of the Mass was de articulis fidei. This scepticism was borne out in De sarcienda where the language of the suggested modus vivendi was loose enough to accommodate both a Catholic and a Melanchthonian understanding of eucharistic sacrifice:

${ }^{8}$ Schirrmacher, 156-158; CR 2:211-212.

${ }^{9}$ Schirmacher, $158-159$.

${ }^{10}$ Honéc, 344. Cf. Bucer to Blaurer \& Zwick, 29.8.1530 (Schiess 1:220-221, no. 172) re. what the Evangelicals were wrilling to concede, "... hane in solitis kirchenkleyderen ac decentis cerenoniis, quaecque ex insitutione Christi susceptae sunt, teverenter celebrasse... ambigua in his plerague sunt:"

I: CR 2:292, 296. 
The ancient, sacred teachers did not shrink from the words "sacrifice" and "immolation." I admit that Christ, having died once, does not die again, but that unique sacrifice is (as it were) daily renewed through the mystic rites when we draw from it fresh grace for ourselves as from an inexhaustible fountain. We immolate a victim for the living and the dead when on their behalf we entreat the Father through the death of his Son. Beyond that, since all prayer, praise and thanksgiving is rightly called a sacrifice, this name is applied to the Mass in particular becausc it contains all these things in a more sacred manner. ${ }^{12}$

Erasmus described the Roman rite as, "thanksgiving which they call 'Eucharist,' reverent commemoration of the Lord's death, and prayers, including the Lord's Prayer." There was nothing there which was not godly and worthy of reverence. ${ }^{13}$ However Erasmus condenned the behaviour of people who wandered about the church chatting during the public offering of the Mass, and then looked for a priest to offer a private Mass or the office for their own special intentions. The nultiplication of private Masses, he wrote, led only to superstition and abuse. That Saint John Lateran had only a single altar suggested to Erasmus that the private Mass was a novelty. ${ }^{14}$ Here it is worth noting that private Mass was criticised on the grounds that it subverted the corporate dimension of the Eucharist. Erasmus claimed, nevertheless, to accept the traditional account of eucharistic sacrifice. ${ }^{15}$

There were other Catholic attempts to address the impasse in the years following Augsburg. 'Two authors in particular, interest us herc. The first is Georg Witzel with whom Bucer would negotiate at Leipzig in 1539. The second is Johannes Gropper with whom Bucer would collaborate in the production of the first draft of the Worms-Regensburg Book in 1540.

\subsection{Georg Witzel}

Witzel (1501-1573) had studied at Erfurt from 1516 to 1518 and then for a semester at Wittenberg in 1520. In the same ycar he was ordaincd and became parish pricst at Vacha in Hesse. In 1524 he married and, on Luther's recommendation, was appointed pastor at Niemegk in 1525. During this period Witzel became convinced that the Lutheran Reformation had produced religious and moral anarchy. He resigned his post at Niemegk in 1531 and in 1532 he produced his first anti-Lutheran tract, Pro defensione bonorum operum adversus

${ }^{12}$ LB 5:503C-D.

I." Ibid., 502 D-E, "... gratiarum actione, quam appellant Eucharistiam, ac religiosa commemoratione mortis Dominicas, rursus precationibus, inter quas est precatio Dominica... Quid it his non pium ac venerandum?"

14 Ibid., $503 \mathrm{~A}-\mathrm{E}$.

${ }^{15}$ Ibid., 503E. 
novos Evangelistas. This was the beginning of a bitter pamphlet skirmish with I.uther's associate Justus Jonas. ${ }^{16}$ In 1533 Witzel wrotc to Erasmus expressing admiration at his ability to stand between the two parties in the religious controversy; the "sophists" and "papists" on the one hand and the "sects" on the other. ${ }^{17}$ In the same year, Witzel published Metbodtus concordiae in which, he set out his own proposals for the restoration of religious unity. ${ }^{18}$ In the course of the next five years Witzel wrote a number of other works on the restoration of discipline and piety. Among these was Von der heiligen Eucharisty odder Mess published in 1534. ${ }^{19}$ In 1538 , he was summoned to Dresden where he became a councillor at the court of George Duke of Saxony.

While in Dresden, Witzel published further sermons on the unity of the church, as well as Typus ecclesiae prioris (1540) an anthology on the liturgical and disciplinary practice of the carly church. In its unpublished form, this appears to have provided the basis for negotiations at the second colloquy of Leipzig. ${ }^{20}$ A Latin translation of Von der beilizen Eucharisty was also published in Leipzig during this period. ${ }^{21}$ Fraenkel has argued for the influence of the Typus on Bucer's Consilium theologicum and Florileginm patristicum. ${ }^{22}$ However, although the two men appeal to similar patristic sententiae, it seems to me impossible to demonstrate that Bucer came upon these by way of Witzel rather than through others sources. If anything, Witzel's influence was a broader one; he sought to demonstrate similarities between the Roman rite and other liturgical evidence from the patristic church and he signalled the readiness of certain Catholics to re-interpret the Mass on this basis.

Like the Catholic negotiators at Augsburg, Witzel claimed that the Canon had been unfairly accused and that if an impartial interpretcr were found, many would find in its favour. ${ }^{23} \mathrm{He}$ was fond in his works of distinguishing between sophistae and scholastici on the one hand and schismatici and sectae (i.e. the Lutherans) on the other (only Zwinglians counted as baeretici). Catbolici and

16 Thompson, 41-54.

${ }^{17}$ Allen 10:93-96, no. 2715.

18 Gcorgii Wicelii Methodus concordiae ecclesiasticae cum exhortatione ad Concilizm, iuxta exemplar excussum adud Nicolaum Wolrab. 1533... adiectae sunt notae marginales, docinina, \& vita ipsitus... per T.I.S. T.P (London: Iohannes Billins, 1625).

19 Von der beiligen Eacharisty odder Mess, nach anweisunge der Schrifft wnd der Eltisten schrifftuerstendigen Hailigen Lerer... (Leipzig: Valten Schuman, 1534).

${ }^{23}$ In the following discussion I have used a slightly later edition: Typus eccleside prioris... reicblich gemebret and von netem gedruckt [s.m.: s.1.] 15忄1). The added sententiae seem to be those included at the end of each chapter under the heading "Hirvon mehr."

${ }^{21}$ De Eucharistia sacrosanctissima ecclesiate Christi Iesu, autbore Georgio Vuicelio, transl. Johannes Lausten (Leipzig: Nicolas Wolrab, 1539).

${ }^{22}$ Fraenkel, "Introduction," BOL 4:xvii-xviii.

23 Witzel, Methodus concordiae, 18, "De Canone lis ingenss est sub judicibus non nimis integriss[imis] verum si ille aequum interpretem adipiscatur, mirabor, ni plures inveniat, qui reo quam qui actori faveant." 
ecclesiastici such as himself passcd along a via regia between the squabbling factions. Witzel did not undertake a defence of the Canon in the Methodus, but the Typus, and to a lesser extent, Von der beyligen Eucharisty seem to represent his attenpt at "impartial" arbitration.

The patristic texts in the Typus were held together with a brief commentary on what Witzel believed their import to be. He began his discussion of the sources of the Roman Mass with a summary of the shape of the liturgy in the Ps.-Dionysian Iierarchia ecclesiastica 3. He noted that this structure was the same as that in the "Mass of the Greels" which he had recently translated into German "for the betterment of all catholics." ${ }^{24}$ Both of thesc sources would feature promincntly in Bucer's writing on the Mass at the time of the Cologne Reformation. Witzel also attempted to trace the development of the Roman rite from what he described as the "fragments" available to him. Few of these fragmenta appear in Bucer's writing on the Mass, and where they do (e.g. Irenaeus Adversus baereses 4) they might just as easily have come to him from another source (e.g. Gropper or an edition). Where the Typus may have influenced Bucer was in its demonstration of correspondences between a number of the Canon's prayers and fragments of eucharistic prayers described in the works of the fathers and in the liturgies of the Eastern church. For cxample, the Unde et memores corresponded with anamnetic prayers in the Liturgies of "Clement" John Chrysostom and Basil, the eucharistic prayer of Ambrose (i.e. in De sacramentis) and the apparent echo of a eucharistic prayer in Cyril of Alexandria's Epistola 17 against Nestorius. ${ }^{25}$

Other aspects of Witzel's teaching on the Eucharist may also have commended him to Bucer as the sort of man who could be worked with. Firstly, Witzel seems, like Bucer, to have been reluctant to let over-precise definitions of Christ's eucharistic presence become an obstacle to unity. Witzel criticised the "Lutheran sect" for opposing transubstantiation. However he also criticised the Scotists for their speculations. For the kirkische, it was enough to know by faith that the body and blood of Christ were truly reccived in the sacrament. ${ }^{25}$ This

\footnotetext{
${ }^{24}$ Work not located. Possibly Euchologion christianorum: Hundert und mebr Christlicher und schoner gebete... allen Gottes furchtigen menschen angeneme (Leipzig, 1538). See Thompson, 219.

${ }^{25}$ Typtu, 27b, "Zuuoran ist das stïck ex Missa Grecorum, wclchs latinischet, sich anfehet: Vhde \& nos serui tui, et plebs tud, memores tunigeniti iti, $\&_{c}$. Welchs vor 1300 . jaren gelesen worden sein sol..." Cites Bessarion, De sacramento eucharistiae (Mohler 3:47) for "James" and "Clement" (see Brightman, xvii, xlvi, xlviii); Cyril of Alexandria, Epistola 17 (PG 77:113), Florilegium (BOL 3:21), n. 25 notes the occurrence of this citation in Witzel, but Bucer had already used it in his Apologial for the Tetrapolitan Confession (BDS 3:290) both natay have aquired it from the Decretum Gratiani 3 de consecr. dist. 2 c. 80 (Friedberg 1:1346).

${ }^{26}$ Von der beyligen Eucharistie, H1a \& P1a, "Zu dem, ists ein yrthum, wiewol yhn wenig sehen, das die Sect auch anderst leret von der Transubsstantia[tion] des Sacraments, denn die gantze Christenheyt... Im sacrament sey eben so wol brod vnd wcin, als fleisch vnd blut, so die Schrifft vad kyrch helt, es sey nach dem gesprochen wort des Herren, nicht mehr brodt vand wein, sondern
} 
statement, at least, left room among the kirkische for the likes of Bucer.

In Von der beyligen Eucharisty Witzel insisted that Christ had instituted the sacrament as a "memorial sacrifice" (Gedenckoppffer which he translated in the same place as oblatio recordativa). He regarded the paschal context of the Last Supper as proof of this and defended the traditional exegesis of the sacrifice of Melchizedek. ${ }^{27}$ $\mathrm{At}$ the forefront of his discussion of the memorial sacrifice was its catabatic aspect. For the faithful the Eucharist was an "icon" or "mirror" through which the memory of Christ's death was refreshed. ${ }^{28}$ It was not a bare nemorial (Gedechtnis) but an anamnesis or Widdergedecbtnis by which those who lived anid the sorrows and cares of this world were continuously reminded of the sacrifice of Christ and perfected through it. ${ }^{29}$

To this point Witzel's understanding of the eucharistic memorial might be said to correspond with the understanding advanced in Bucer's Psalm commentary. However, against the Lutheran "sect" Witzel argued that Christ had not instituted the sacrament with the words, "do this for the forgiveness of sins." Like earlier Catholic apologists, he argued that the forgiveness of sins was obtained by the pouring out of Christ's blood on the cross. Thus the eucharistic Gedenckopffer made everything obtained through the shedding of Christ's blood on the cross available for all the baptised botb living and the dead. The priest offered it for the washing away of their sins, for and for the salvation of all people (i.e. even the nonbaptised). ${ }^{30}$

Despite this, Witzel refrained from referring to "application" or the opus operatum. The Typus also urged caution on the question of the private Mass and

schlecht fleisch vnd blut." Ibid., H1b, the Kirchische, "stehen vnd reden, vber vnd widder aller menschen weisheyc, kunst vand vernunfft das Christi fleisch vnd blut warfafftig im Sacrament emphfangen werde, vad das zuuerstehen, ist allein der glaub gnuy."; H3a, "Es bringt dem Sacranent kleyne elhre, vad wenig frumerl, das vber diese Scotische broctercy so vil Sophistischer fragen zu zote gehenl,"

${ }^{27} \mathrm{Ibid}, \mathrm{I2a}, \mathrm{K} 1 \mathrm{~b} \mathrm{ff}$.

${ }^{28}$ See e.g. ibid., M4a, "Sie sollen seyn der gegenwertigen Kyrchen ein sichtlich Representation odder fuersiellung des selbigen eynigen oplfers, durch welche dem Christen volck das gedechtnis des leydens Christi erfrischer, vad vnscru hertzen gleich vernewert werde... Sie sol seyn das recht Icon des creutzoplfers, vnd wie ein spiegcl des Herren leidcns. Nu kan diese furstellung vnd haltung des gedechtnus yn keiner weise oder form schicklicher geschehen, denn wie die Kyrche thut, ynn dem sie Gott Melch[isedeks] opffer bringt, nach dor weysc, dic Christus im Abendmal gehalten vnd gepoten."

${ }^{29}$ Ibid., L1a, "...so wil der Kriechen Avajuvnots cin widderholets Denclsopfor haben, den sie

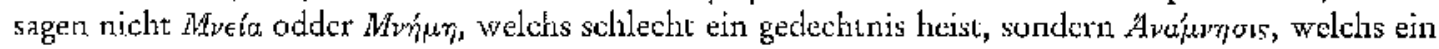
widdergedechtnis heist, das do widder vnd aber widder gescheen sol, darauff saget Patus, so offt $\mathrm{yhrs}$ tbut \&c. [1 Cor 11:26] denn Ana feyret nicht. Kurz dis denclibrod sol cin solch werk odder Latry seyn, das vns das eynig opffer Ihesu Christi an Creutz fuer vis volnbracht, ynn stetigem, volkomend, stritschem gedechtnis bchalte, yn so viel sorgen vad aengsten dieser welt, daryn wir leben muessen.

${ }^{30}$ Ibid., P3a-P4b. 
prayer for the dead. The offices of the dead in the early church were discussed, but not in the context of the Eucharist. On Purgatory, Witzel's only comment was that the early church, "had not quarrelled about it." 31 He confessed that he did not know what the origin of plural Masses was. He noted that Gregory the Great had mentioned thirteen altars in onc church, but asserted that the "church of the fathers" did not mention this practice. ${ }^{32}$ Like Melanchthon, he emphasised that while the patristic sources referred to a daily offering of the Eucharist, they also referred to daily communion by the people. They also referred to a single altar in each church. Thus, while he did not question the private Mass directly, this data suggests that Witzel sought a moderation of the number of Masses, especially those without communicants. ${ }^{33}$ On prayer and almsgiving for the dead, he wrote that these practices clearly had the warrant of the earliest church, but their relationship with Purgatory should not be pursued with immodica asseveratio. Indeed it would be better if all were to live so that they did not need undergo such punishment in the afterlife. ${ }^{3 *}$

\subsection{Johannes Gropper}

Johannes Gropper (1503-1559) a jurist and Keeper of the Great Seal of the Archdiocese of Cologne, attended the Diet of Augsburg in the retinue of the Archbishop and Elector, Hermann von Wied. His observation of the religious debate and negotiation there led him to undertake intensive private study of the writing of the Reformers, Scripture and the fathers. Like many Humanists, Gropper had initially regarded the Reformation as a continuation of the struggle between the new learning and monkish obscurantism which had characterised the Reuchlin affair. However, as a consequence of his thcological study, Gropper made a decision for the Catholic side. ${ }^{35}$

The Anabaptist rising of 15.33-1535 in nearby Münster was read by Hermann von Wied as a warning of the anarchy which would follow if popular discontent with the church were not assuaged. In the neighbouring Duchy of Julich-Cleves, he had an example of moderate reform in the church order or

${ }^{31}$ Typus, 69a-70b.

${ }^{32}$ Ibid., 23b, "Wenn, woher, und warumb die pluralitet der Missen auffkomen, gibt vns nichts zu schaffen..." Cf. Gregory Epistola 150 (PL 77:834).

19 Ibid., 26a, 16b-17a, "Dann solche ordenung haben die Sacrament, Predigt, Tauff, Firmung, speisung. Tauf und Firmung geschach an dem glaeubigen ein mal, aber predigt vnd dise speise vad tranck teglich." Cf. Augustine, Epistola 54.3 (PL 33:201); Jerome, Epistola 71 "ad Lucium" (PL, 22:672).

${ }^{34}$ Methodus, 58-59.

${ }^{35}$ T.ipgens, Kardinal Johannes Gropper, 1503-1559 und die Anfange der katbolischen Reform in Deutschland (Münster, 1951), 9-51. 
Declaratio promulgated under Duke John in $15333^{36}$ In 1535 the Archbishop commissioned Gropper to draw up an agenda for a provincial "council" or synod which would institute a similar programme of reform in the Electorate of Cologne. ${ }^{37}$ The Synod met in 1536. The fruits of Gropper's labours appeared in the Encbiridion christianae institutionis published in 1538 as an appendix to the Canons of the Synod. ${ }^{38}$

The Canons urged a programme of preaching, "of canonical Scripture and the divine utterances according to the ecclesiastical interpretation of the holy fathers and teachers." ${ }^{39}$ The Encbiridion was intended to provide a model and source-book for such sermons. It would "briefly" explain the Decalogue, the Apostles' Creed, the seven sacraments and the Lord's Prayer "according to sound church doctrine" and give common-places suitable for the exhortation of "all ages and ranks." ${ }^{40}$

Separated from the Canones under the title Institutio compendaria doctrinae christanae, the Enchiridion ran to at least a further seventecn editions in Italy, France and the Low Countries. ${ }^{41}$ It was particularly warmly received by teformminded members of the Roman curia such as Cardinals Contarini, Sadoleto and Pole. ${ }^{42}$ The enthusiasm with which the Enchiridion was greeted in England is suggested by Melanchthon's letters to Henry VIII and Thomas Cranmer warning against its charms. ${ }^{43}$ Both Luther and Melanchthon regarded the book as a cunning attempt to conceal the errors of the papist church with "sophistical glosses." It was more likely, Luther thought, to inflame divisions in the church than lead to concord. ${ }^{44}$ Ironically, the reforms of the provincial synod met with a half-hearted

${ }^{36}$ Mechtild Köhn, Matrin Bucers Entvourf einer Reformation des Erzstiftes Kölr: Untersuchung dor Enststebungsgeschichte and der Theologie des "Einfaltigen Bedenckens" won 1543. (Wittenberg, 1966), 19-23.

${ }^{37}$ Lipgens, 51-66; Köhn, 24-33.

${ }^{38}$ Canones Concilli Prouincialis Coloniensis... quibus altectum est Encheridion $\lfloor$ sic] christianae institutionis (Cologne \& Leipzig: Nicolas Wolrab, 1538). Final version of the canons, as well as drafts, in ARC 2:192-305. For the Encbridion, I have used the 1538 edition of the Cantones.

39 Canones 6.20 (ARC 2:253), "Surnma doctrinac cluxistianac in Enchiridion contrahenda: Porro cum secundum evangelicam atque apostolicam doctrinam... in ecclesia dei sola canonica scriptura ac divina eloquia secundum ecclesiastican interpretationem sanctorum patrum ac doctorum et recitari et pracdiciui debeat, non abs $\mathrm{re}$ videtur parochis summam bibliorum paucissimis praescribere, ne alicubi dum scripturae metas nesciunt."

${ }^{10}$ Canones 6.21 (ARC 2:253).

${ }^{* 1}$ Por details see Lipgens, 255.

"2. Braunisch, Die Theologie der Rechtfertigang im "Enchiridion" (1538) des Jobannes Gropper: sein kritischer Dialog mit Pbilipp Melancbthon, (Mïnster, 1974), 37-44.

${ }^{43} \mathrm{CR} 3: 678,682,808$. See esp. CR 3:814 to Henry VHl, 1,11.1539, "Ac frustra hic finguntur sophismata ad excusandam applicationem. Nemo ex universo populo aliter sentit, quans hoc opus prodesse universae Ecctestae. Ipse etian Canon Missne hoc profitetur. Quid ludunt verbis quidam astuti, qui negant se applicare Missas cum sciant suo facto confumari populi erroren etiansi ipsi aliter sentiant."

${ }^{44}$ WABr 8:349, no. 3287 (see also CR 3;960); WABr 9:52, no. 3444. 
reception in the territory of Cologne itself. Six years later, Hermann would cnlist Bucer's help in a far more radical reformation of his Archdiocese, and we shall turn our attention to this in Chapters Nine and Ten.

The fact that the Enchiridion was placed on the Index in 1596 may suggest that, from a post-Tridentine viewpoint at least, its contents were unorthodox. ${ }^{45}$ Although Gropper attended the Council of Trent and was made a cardinal shortly before his death in 1559, it was alleged that the Enchiridion caught "double justification," (i.e. that justification has a double formal cause: the imputed righteousness of Christ, and "inherent righteousness" through which faith is made eflective in the works of love). This view had been advanced by a number of theologians at Trent, and was everitually excluded (though not condemned) by the Tridentinc decree on justification. ${ }^{46}$ It is clear that Gropper's own views on justification were tainted in the eyes of subsequent theologians because of his association with the agreement on justification reached at Regensburg in 1541. More, recently, however Rcinhard Braunisch has questioned the fairness of this assessment of Gropper's teaching of justification. ${ }^{47}$ Whether or not Braunisch is right, Gropper's attempts to appropriate the Evangclical language of "imputed righteousness" within a Catholic framework seem to have recommended him to Bucer. Buccr had already read the Enchiridion whon he attended the Diet of Hagenau in 1540. He made a point of meeting Gropper there and presented him with his Romans commentary. ${ }^{48}$ As in the Furbereytung, a convergence of views on the nature of justification seems to have created an atmosphere of trust in which other disputed matters could be discussed.

Gropper's views on the eucharistic sacrifice were orthodox from both a pre. and post-Tridentine standpoint. It is clear, nevertheless, that the section on the Eucharist in the Encbiridion was written with an eye to assuring his opponents that there was no opposition between the Mass and the doctrine of justification. Despite the promised "brevity" of the Enchiridion, its exposition on the sacrifice of the Mass was a long one.4"

${ }^{45}$ Braunisch, Die Theologie, 44.

${ }^{46}$ DS 799. See also the sententia of the Jesuit gencral Lainez, CT 5:542, 617.

${ }^{27}$ Braunisch, Die Theologic, 419-438 clains that Gropper, like Trent, teaches a single formal carne but distinguishes between its two aspects: i,e. remission of sins and the inward renovation of the mind. He compares this with Aquinas' "Iustificatio dupliciter dicitur..." in ST 1a 2ae q.100 a.12.

${ }^{18}$ Augustijn, "L'Esprit d'Erasme an Colloque du Worms," 383-384; The principal accounts of this meeting are in: Gropper, An die Roemsche Keyserliche Maiestat... Warbafftige Antwon und gegenberichtung... (Cologne: Iaspar Gemepaeus, 1545), 36b-38a; Bucer, De concilio et legitime itdicandis controversis... (Strasbourg: Officina Knoblochiana, 1545), p2b (Stupperich, 85); Von den cinigen recthten twegen... (Strasbourg: Wendel Rihel, 1545), 56-62 (Stupperich, 59)

4" Gropper, Enchiridion, 98a, "In qua res explicanda, si paulo diutius immoremur, quam Encheridij breuitas patiatur, nemo nobis vitio verterit, quod operae pretiun fore puternus..." 
At the heart of the exposition was an attempt to link Melanchthon's sacrificium eucbaristikon and sacrificium propitiatorium and to resolve the opposition he had found between sacrament and sacrifice..$^{50}$ In order to do this, Gropper depended heavily on the account of Christian sacrifice in Augustine's $D e$ civitate Dei 10 . He defined sacrifice as sacrum factum: a deed dedicated to God alone; one through which we "name, offer, return and dedicate" to God what is properly owed to him. ${ }^{51}$ Human creatures could give God nothing which he had not already given them. What they owed to God was to obey, love, worship and trust in him in whose image they had been created. This was the sacrificium laudis which God asks of us. Before the fall Adam and Eve had been able, with God's assistance, to offer this worship of their free volition. After the fall, however, humans were absolutely incapable of rendering to God what they owed him. Gropper dwelt at length on the incapacity of humanity vitiated through original $\sin ^{52}$ Fallen humanity required one who would reconcile it with God though a sacrifice which would propitiate an offended God, overcome the devil, and enable the reconciled to render again the sacrifices of praise due to God. ${ }^{53}$

The sacrifices of the natural Law and the Law of Moses prefigured the truly propitiatory sacrifice of Christ. However they had two further functions. Firstly, they allowed those who offercd them to express their trust that from the foundation of the world there was no other way to be saved than through this one victim. Secondly, and minus principaliter, they also signified the sacrificia pietutis: the good works which wcre the necessary consequence of faith in the sacrifice of Christ:

whence it follows that all the many kinds of sacrifices which God taught were to be performed in the Tabernacle, may be taken to signify the love of God and neighbour. For the whole of the law and the prophets hangs on these two $\mathrm{o}^{54}$

This was why the prophets and the Psalms had rebuked those who believed

${ }^{\text {i9 }}$ See above ch. 3 and in Loci communes (1535) (CR 21:480-481).

${ }^{51}$ Enchridion, 98a. Gropper does not used the ready-made (Lepin, 80) definition in $D c$ civitate Dei 10.6 (PL 41:283) "verum sacrificium est omne opus, quod agitur ut sancta societate inhaeramus Deo, relatum scilicer ad illum finem boni, quo veraciter benti esse possinntss." His definition was probably chosen for its similarity to Melanchthon, Loci communes (1535) (CR 21:480), "Sacrificium est cerenonia vel opus nostrum, quod nos Deo reddimus, ut eum honore afficiamus; hoc est, testamur nos agnoscere hunc ipsum, cui hanc obedientiam praestamus, were csse Dcum, ideoque nos ei hanc obedientiam praestare."

${ }^{5 ?}$ Enchinidion, $98 \mathrm{~b}-100 \mathrm{~b}$.

${ }^{53}$ Ibid., 100b-101b.

${ }^{54}$ Ibid., 103a, "Vnde consequitur, vt quaecunque in mixistcrio tabernaculi multis modis de sacrificijs leguntur diuinitus esse praccepta, ad dilcctionem dei $\&$ proxinni significandam referantur. Quod in his duobus praeceptis vniuersa lex [endcat \& prophetae..." 
that they could be justified through the performance of the external cult without faith in the remission of sins or regard to their neighbours. To this extent there was no difference between the sacrifices of the Old Testament and those sacrificia pietatis to which the New Testament referred (e.g. Rom 12:1). ${ }^{55}$ Whether before the passion, death and resurrection of Christ or afterwards, genuine sacrificia pietas were fundamentally the sacrifice of Christ. ${ }^{56}$ It could also be said that the members of Christ's body, whether in the Old 'T'estannent or the New, were "offered" through him to the Father. Here Gropper quoted from De civitate Dei 10.6:

... and in as much as all the works of godliness and mercy are rightly called sacrifices, and rightly said to be offered to God through Christ working in us, "it immediately comes to pass that the whole city of the redeemed, that is, the congregation and society of the saints, is offered as a sacrifice to God through the same great priest. He first offered himself for us in his passion in the form of a slave, so that we might be the body of so great a head. For this is what he offered, in it he is offered, according to it he is mediator, in it he is priest, in it he is sacrifice." $" 57$

Here, however, Gropper added a qualification. The Ncw Testamnent had done away with "allegory and equivocation." In instituting the Eucharist, Christ named and handed to his disciples the truth of his body and blood, and not just any body and blood but the one "which is given up for you." ${ }^{38}$ Apparently addressing himself directly to the Melanchthonian distinction between sacrament and sacrifice, Gropper admitted that, the body and blood of Christ present on the altar were, "more properly called 'sacrament' than 'sacrifice":

${ }^{55}$ Ibid., 101b-102b

${ }^{56}$ Ibid., 102b, "Patres ergo veteris testamenti, quum se promissionis esse filios per fidem intelligerent, spiritui seruitutis in timore valedixerunt, acceptoque spiritu adoptionis filiontum dei... summa ope contenderunt, vt se totos per hanc fiduciam deo consecrarent... reputantes eiusmodi pietat is erga deum studia \& officia vera esse sacrificia, quae a reconciliatis filijs pater requireret, non quidem vt propitiatoria, nam illud vnicum est, sed vt sacrificia filialis fiduciae, debitae obedientiae laudis, \& gratiarum actionis, quae quum ex solius Christi sacrificio onnen suun valorem mutuentur ac fortiantur, atque adeo dona sint dei, \& propemodum non nostra, sed Christi sacrificia, quae Christus in membris suis per fidern facit ac operatur."

${ }^{57}$ Ibid., 103b, "Et demum, omnia pietatis ac misericordiae opera, recte sacrificia appellentur, ac deo per Christum in nobis operantem offerri recte dicantur, profecto efficitur, vt tota ipsa redempta ciritas, boc est, congregatio, societasque sanclorum, velut vinitursale sacrificium offeratur deo per eundem illum sacerdotem magnum, qui prius seipsum obtulil in passione pro nobis, wt tanti capitis corpus essemus secundtum formam serui, banc enim obutit, in hac oblatus est, quia secundum banc mediator est, in bac satcerdos, in bac sacrificium." Cf. PL 41:284.

${ }_{\text {5a }}$ Ibid., 94a, "Proinde cunctis figurarum vel similitudinum nebulis amotis, non corpus quodlibet, sed corpus domini, quod pro nobis traditum est, edere, $8 x$ illum sanguinem, qui pro nobis effusus est in remissionem peccatorum, nos bibere indubitato credimus..." 
for sacrament and sacrifice may be seen to differ in so far as a sacrament is a holy sign through which God represents something to us, whereas a sacrifice is something we render to God. ${ }^{5 y}$

However, this was the sacrament of Christ's sacrifice, "in which he himself is the priest and offering which avails forever. ${ }^{\$ 50}$ Moreover, where the priesthood and sacrifice of Christ's body and blood were present, so too was the offering of his mystical body. Here Gropper distinguished between the res ablata and the oblatio of the Mass. The res oblata was twofold: the true body of Christ with all its morits and the mystical body of Christ with all the gifts which it had received from God. ${ }^{61}$ This sacrifice was, "no less acceptable today in the sight of the Father than on that day on which blood and water flowed from his sidc." ${ }^{32}$ All propitiatory value, merit and satisfaction in the Mass were to be attributed to the res oblata prescnt sacrificially. This was the opus operatum of the Mass. ${ }^{63}$

The oblatio was also twofold: it was the outward actio of the Mass which the church performed in obedience to Christ's command to do this in his memory. It was also the inward spiritual offering which was performed through faith and the outward action. ${ }^{64}$ In the oblatio the church called to mind the goodness and the works of God, particularly Christ's passion, death and resurrection. Of itself this availed nothing ex opere operato. ${ }^{65}$

In other words, the res oblata was the work of redemption already perfected; the perfect unity of Christ and his members present in mysterio. T'he oblatio was the church militant in whose midst the petfect unity of the body was present but not yet fully realised. ${ }^{66}$ Through the Eucharist, a "pledge of luture glory," the work was

59 Ibid., 104b, "... Licet secundum franc rationem corpus domini in altari non omnino proprie dicatur sacrificium, sed magis sacramentum, selt res sacranenti, quod sacramontum $8 x$ sacrificium eo differre videantur, vi sacramentun sit sacrosanctum signum, per quod deus nobis aliquid extibet. Sacrificium vero quod nos deo reddimus..."

${ }^{60}$ Ibid., "...Attamen... patres non dubitarunt, hoc Christi corpus in altari sacrificium \& salutarem victimam appellare, non ratione sacrificij, quod est situm in actione saccrdatis, sen missae communicantium, aut ecclesiae, sed ratione sacrificij, quod in cruce oblatum est semcl, in quo Christus saccrdos est, ipse \& oblatio in sempiternum potens. Eo enim cluod manet in acternum, sempiternum habet sacerdotium." Cf. Autgustine, De civilate Dei 10.5 (PL 41:282), "Sacrificium ergo visibile invisibilis sacrificii sacramentum, id est sacrum signum est."

${ }^{61}$ Ibid., 104a, "In missa itauje duo sunt, res oblata, ipsa item oblatio. Rursus, res oblata duplex est, videlicet corpus Christi verum, $8 x$ corpus Christi mysticum."

"2 Thid., 104b, “... sic in betneplacito dei constat acceptabile, \& perpetun virture consistit, vt non mirus hodic in conspectu patris oblatio illa sit efficax, quam eo die qua de saucio latere sanguis \&x ac1na exiuit..."

63 Ibid., 105a.

${ }^{64}$ Ibid., 105a-106b.

${ }^{65}$ Ibid., 105a.

"Cf. the exposition on justification, ibid., 132a, "Postquam enim deus per gratiam iustificantem nos recipit in filios \& coheeredes Christi, idque per fidem, fit vt postea opera nostra tanquam filiorum \& reconciliatorum, in fide \& timore filiali facta, licet non admodum perfecta, \& absoluta, deo placearn, quia iam placent personae per Christum, ex cuius perfectione nostram 
brought to completion in them. ${ }^{67}$ Throughout his account, Gropper stressed that the reception of communion was the natural end of the sacrament. Reception of the body and blood of Christ acted as a brake on concupiscence and a strengthening against sin so that Christ lived more and more in the faithlul and they in him. ${ }^{68}$ Fence the Canons of the provincial council urged that the people confess and receive communion as often as possible. They forbade the celebration of private Masses until the public Mass on Sunday had been celebrated, and urged the people to stay at the public Mass until communion, the praceipua missae pars. ${ }^{64}$

At no point in his account did Gropper use the word "transubstantiation," however he undoubtedly taught the substantial conversion which transubstantiation describes. ${ }^{70}$ The opening paragraph of the Enchiridion's chapter on the Eucharist stressed the correspondence between the complete transformation of the sacramental elements into the body and blood of Christ and the church militant's gradual transformation into the nature and substance of Christ through participation in the sacrament of his body and blood. In this the Eucharist differed from the other sacraments in which the outward element was not transformed. ${ }^{71} \mathrm{In}$ a remark probably directed at the Sacramentarians, Gropper emphasised that the risen flesh of the Saviour was not separated from his soul or divinity, but was lifegiving. ${ }^{72}$ Thus through the sacrament the faithful united with Christ:

not only spiritually (as happens through right faith and sincere charity) but also bodily, so that we are not only joined together in the Spirit,

impericctionem supplemus, sumus enim membra corporis eius ex carre \& ussibus cius, De plenitudine eius omnes accipientes \& iustitiam eius nostram facicutes."

6.7 Ibid., 91.

6s Enchiridion 113b, "Principalis ergo huius sacramenti virtus est, vt qui sumit hoc sacramentum carnis \& sanguinis domini, ita cum ipso coniungatur vt Christus in ipso \&c ipse in Christo inucnisatur..."; $115 \mathrm{~b}$.

${ }^{69}$ Canones 7.21, 24, 26 (ARC 2:261-264).

${ }^{70}$ See ibid, 93a-94b where he repcats the Catholic argument that if Scripture refers to the consecrated bread as "breac" it is in the sense of the "Bread of Life" and the "Bread of Angels." See also ibid., $96 \mathrm{~b}$ re. the fraction of the host, "quae quidem Iractio in spccic tantum panis fit, quac post consecrationem remanet sine subiecto, Christus vero in teger manet \& totus in singulis pariculis..."

${ }_{71}$ Ibid., 90b, "Et eatenus hoc sacramentum cheteris sacramentis, tum veteris, tum noui testamenti maius \& excellentius est, guod in alijs elementum scu exterior species nullam substantialem mutationem recipit... At solum sacramentum panis \& vini potentia verbi diuini ita mutatur, vt substantialitcr non sit quod ante fuerat, sed quae ante consecrationem erant panis $\&$ vinum, post consccrationem sint substantialis caro \& sanguis Christi."

72 Ibid., 94b-95a, "Absit enim, vt vel in mentem nostram subeat Christi corpus post resurrectionem, vel a sanguine, vel ab anima, vel a diuinitate scparari... Et ideo in Ephesino Concilio [can. 11] contra Nestoriam diffinitum est, nos were vivifualricem, \& ipsiss verbi proprian factam. carnem percipere." Cf. Mansi 4:1803. 
but are also members of his body and of his flesh and of his bones, as we read in Saint Paul's letter to the Ephesians 5:[30]. ${ }^{73}$

The bread of the Eucharist was the mystery of the church's unity in the body of Christ. Alluding to Augustine's mystagogical Easter Sermo 229, Gropper wrote that through Baptism, Confirmation, Penance and the Eucharist the faithful were, "baked into Christ's bread."

Yet the faithful who participated in the sacrament were joined not only with others who participated in the sacrament simultaneously, but with the whole body of Christ living and dead. Gropper described this as the ratio synaxeos: the "sense" or "point" of the communion which the baptised had with Christ and one another. ${ }^{75}$ The faithful could not recall the self-offering of Christ and not be ready to offer themselves in the service of their neighbour. ${ }^{76}$ Equally, they could not celebrate the eucharistic memorial and not recall the saints, the faithful departed, and all people, believers and unbelievers alike."

Here Groppcr produced stock scntentiae and arguments in favour of the memorial of the saints and the faithful departed. I will not rehearse these here, though some will be noted in the discussion of the Worms-Regensburg Book later in the chapter. However, the distinctions which the Enchiridion makes regarding the application of the Mass are worth noting. With regard to the res oblata ;

nothing is proper to the [ministerial] priest, but Christ performs the whole action, when even today he creates, sanctifies and blesses his most true and holy body and shares it out among those who partake of it in a godly manner. ${ }^{78}$

The ministerial priest consecrated vice Cbristi pronouncing the words of

${ }^{73}$ Ibid., 90b, "Vnde id... consequitu, nempe nos virtute huius tam eximij sacramenti non solum spiritualiter (quod recta fide, charitateque syncera sit) sed \& corporaliter Christo vniri, vt simus non tantum spiritu ei conglutinati, sed \& simus membra corporis eizs ex came \& ex ossibus cits." See Eph 5:30 (Vulgate).

74 Ibid., 115b. See Augnstine, Sermo 229 "De sacramentis fidelium, feria 2 Paschat" (PL 38:1103) Possibly via Decretum Gratiani 3 de consecr. dist.2 c.36 (Friedberg 1:1326).

75 Enchiridion, 110a, "Commutionem vocauerint, quod qui hoc sacramento digne communicat, certus sit se in Christi corpore esse, \& sanctorum omnium (qui eiusdcm corporis membra sunt) meritis ac precibus adiuuari, defendi, ac confirmari. Engo synaxis ratio omnino reqirit, ve ecclesia militans... ad altari donirni recordetur... quod sanctos, alioqui semper pro nobis apud eum solicitos excitet." See also ibid., 110b, "Porro quun synaxcos ratio requirat, sanctorum connxemorationem in missa fieri, quanto magis par est, vt \& defunctorun in Christo ad tanti sacrificij oblationem memores simus..."

${ }^{76}$ Ibid., $107 \mathrm{~b}$.

77 Ibid., 108a-113b.

${ }^{78}$ Ibid., 104b, “...in hoc sactamento nihil proprium est sacerdotis, sed totum agit Christus, qui vsque hadie hoc veracissimum \& sanctissinum corpus summ creat, sanctificat, benedicit, \& pie sumentibus diuidit." 
Christ. ${ }^{79}$ This action made Christ present as priest and sacrifice with the offering of his mystical body and all its benefits including the merits of the saints. Yet it was atnother thing for the church to "offer the true body of Christ or the mystical body to God" (i.e. to pray for the living and the dead and to seck association with the merits of the saints). This no-one did except through faith and a motus bonus of the heart. In the oblatio the ministerial priest acted ex persona ecclesiae uti minister publicus. Nothing was attributed to his prayer ex opere operato. ${ }^{\mathrm{kO}}$ "lhe beneficiaries named by the priest benefited only in so far as they were joined to the mystical body of Christ through faith. God, rather than the priest "applied" the benefits of Christ to those who received them in faith, and even that faith was not their work but the work of God in them."

Although Francis Clark has described Gropper's view of the Eucharist as "Scotist," his understanding of application corresponds better with what Iserloh has characterised as "Thomist." "This much is evident from the Apologia (1542) which Eck wrote in defcnce of his participation in the Colloquy of Regensburg. Gropper's description of the eucharistic sacrifice as, "no less effective in the sight of the Tather than on that day on which the blood flowed from his side" offended Eck's "Scotist" sensibilities:

If the daily offering is equally efficacious, as it was on Good Friday on the altar of the cross, it follows that there is no distance betwcen the bloody sacrifice and the unbloody one; no difference between the true and real offering and the representative one... If all the offerings were equally efficacious, it would follow that they were of the same value. Yet the offering of Christ on the cross was of infinite value, for it is the propitiation for our sins and those of the whole world... but the daily offering in the Mass is of a finite value. Otherwise one daily Mass would suffice for the sins of the whole world. ${ }^{63}$

${ }^{79}$ Ibid., 105a, "Aliud est enim conficere corpus Christi, quod facit sacerdos Christi vice, Christi verba pronuntians, aliud vero offerre deo Cliristi corpus vertum. vel mysticum, quod nemo vtiliter facit, nisi accedat vera fides \& bonus motus, vel offerentis vel eius pro quo fit oblatio."

${ }^{\text {sa }}$ Ibid., 108a, "Vnde inquit, memores domini... \&c. cui sane hostiae (non suo operi operato, $v t$ vocant) vitae aeternae \& salutis perpetuae efficaciam tribuit. Ergo non suam oblationem applicat, sed fructum oblationis Christi, quatn recolendo rememorat, per fidem sibi applicari petit."

${ }^{81} \mathrm{lbid}$., 106b, "Nec enim hanc applicationen sacerdoti, sed deo tribuimus, non operi nostro, sed dei beneficio, quod tamen non aliter quan voluntatis nostrae assersu per fidem accipimus. Idque etiam vt possimus, is velle \& perficere qui dat sua bona voluntate."

82. Clark, 262.

${ }^{83}$ Eck, Apologia... aduersus mucores et calumnias Buceri super actis comitorum Ratisbonae (Cologne: Melchior Nouesianus, 1542), N1b-N2a, "Si oblatio hodierna est aeque efficax, sicut in die parasceves in ara crucis, sequitur nullam esse distantiam inter sacrificitom cruentum et incruentum, nullam esse differcntiam inter oblationem veram realen et inter repracsentatiuam: Nilhil referre inter Christum vere oblatum et exemplar illius et conmemorationem semel facti sactificij. Sequeretur, si essent oblationes aeque efficaces, essent eiusdem valoris; oblatio autem Christi in cruce 
Clark is correct when he describes the church's oblatio in Gropper's account as a "pleading" of Christ's sacrifice, but he does not seem to take into account Gropper's understanding of what is "present on the altar." For Gropper the res oblata is both the body and blood of Christ sacrificed on the cross and the corpus Christi mysticum. Thus application ex opere operato occurs when the sacrament is consecrated and the benefits won by Christ for his mystical body are made present in all their infinity. There is no question of an imperfect mediate opus, constrained by the merit of the church militant, through which the benefits of the perfect sacrificial victim are meted out to intended beneficiaries. Where the priest and church do act as intermediaries or "delegates" in Gropper's account, it is in a manner analogous with other sacraments. Just as Christ baptises, so Christ blesses, consecrates and distributes the sacrament. The church's minister prays on behalf of the people that what Christ has won will be of benefit to both the living and the dead. This, however, is intercession - application in a secondary sense, ex opere operantis.

For Gropper the sacrifice of Christ, present in mysterio, was the constituitive sacrifice of the Mass, but he did not explicitly identify the consecration as a sacrificial act. ${ }^{.4}$ If, like Eck, one believed that the consecration was simply the making present of the sacrificial victim, but not in itself sacrificial, then Gropper's distinction between the consecration of the sacrament and the oblatio of the church could be interpreted to mean that the church's offerimus was only a figurative offering of prayer, incidental to the sacrament but not of its very nature. ${ }^{65}$ This certainly seems to be how Bucer interpreted Gropper's account. However, differences between Gropper and Bucer about the nature of the institution of the Eucharist would not become clear until after 1541.

Nevertheless, Gropper's emphasis on the transformation of the corpus Christi ecclesiasticum into the corpus Christi mysticum by means of the corpus Christi

fuit infiniti valoris, quia ipse est propiciatio pro peccatis nostris et totius mundi... oblatio autem quotidiana in missa est finiti valoris, alioquin sufficeret quotidie una missa in toto mundo."

${ }^{84}$ Here his trentment of the Mass can be fruitfully compared with Cajetan's De sacrificio missae aduersus Luteranos inxia scripturam tractatis, (Rome: Gerardus Bladus Asulanus, 1531). Lilse Gropper, Cajetan regards the presence of Christ's sacrificed body and blood as constituitive of the eucharistic sacrifice, but states explicitly that the consecration is itself sacrificial as it makes present not just the body of Christ, but (A.3b) "corpus christi quod frangitur seu datur pro tobis." Christ is thus present in the Mass immolatitio modo: i.e. in the manner of one sacrified. At 'I'rent (Cl' 7.2:445-446) Gropper would refer to approvingly to this work. He would also refer, ibid. 446, 1. 4 to Cajetan's Opuscula aurea. We do not know whether Gropper had read either prior to writing the Enchiridion. Since Gropper's education at the University of Cologne was in the Thomist via antiqua (Lipgens, 15-27) it may be that any similarities at this time result from a conmon "Thomism."

${ }^{35}$ See e.g. his comments on the application of the Mass in CT 7.2:445, 1. 38-4.t6, I. 2, "Accedit quidem huic operi Christi opus sacetdotis. Sacerdotes operant, sed huic opert per se sumpto nemo tribuit meritum remissionis peccatorum seu etian vim applicationis eitsden pro sacerdotis arbitrio." 
cucharisticum seens likely to have commended itself to Bucer. In the Bericht, Bucer had quoted Augustine's words in the mystagogical Sermo 272: "When you hear, "the body of Christ,' and answer 'Amen,' be a member of the body of Christ, in order that your 'Amen' may be true." 36 At this point, Bucer had been defending the patristic language of natural and corporal presence on the grounds that the "communion in the body of Christ" was no mere figure of speech but a work of God whereby the Lord dwelt in the faithful naturally and bodily. ${ }^{87}$ Augustine, he wrote, meant that Christ imparted his true body and blood offered up on the cross in order that he might be in the faithful and they in him, his limbs and his body. ${ }^{88}$ As Hammann points out, in the 1530s the Lord's Supper became for Bucer not merely faithful proclamation of what the church and the faithful had through the sacrificial dcath of Christ, but the habitual and sacramental means by which the Holy Spirit realised the einleybung in the body of Christ begun in the sacrament of Baptism, and actualised (albeit imperfectly) in the corporate life of the faithful. ${ }^{89}$

However, while Gropper saw transubstantiation as implicit in this transformation, Buccr would maintain a careful distinction between the external and internal aspects of the eucharistic mystery. As we shall see, he would admit the language of sacramental "transformation" in connection with the unio sacramentalis between the elements of bread and wine and the body and blood of Clirist. However, this transformation was realised for and among the faithful only. In the Bericht and in the 1536 edition of his Commentary on John (specifically, John 6:56) he appealed to Augustine's De civitate dei 21.25 which maintained that heretics and schismatics separated from the unity of the body of Christ consumed the "sacrament" of the body and blood of Christ but did not truly eat Christ's flesh. Because they did not reccive the benefits of Christ's death by faith, they could not be said to dwell re vera in Christ nor he in them. ${ }^{90}$

${ }^{86}$ BDS 5:245 incorrectly cites Sermo 22\% "ad infantes de sacramentis" (PL 38:1099-1011). In fact Sermo 272 "ad infantes de sacramento" (PL 38:1247), "Si ergo vos estis corpus Christi et nembra, nysterium vestrum in mensa Dominica positum est: mysterium vestrum accipitis, Ad id quod estis, Amen respondetis, et respondendo subscribitis. Audis enim, corpus Christi; et respondes, Amen, Esto nembrum corporis Christi, ut verum sit Amen."

${ }^{87}$ BDS 5:244.

${ }^{83}$ Ibid., 245.

${ }^{89} \mathrm{H}$ Tammant1, 227-230, 389, Cf. BDS 5:190, 252.

${ }^{50} \mathrm{Ibid}$; BOL 2:263, 272-273 "Hic scribit divus Augustinus... re vera manducare Dominum esse manere in Domino et habere illum in se manentem idque Dominum ipsum sequenti dicto: Qui mandiscat... Uohn 6:56] Iam sunt qui corpus Domini in sacra cucharistia sumunt, nec tamen demittunt in ventrem animac, hoc est: non reputant dignc fidc sua beneficium Domini... Proinde non propric et simpliciter edere illud dicuntur divo Augustino, sed sacramentotenus." Sec PL $41: 741-743$, csp. 742 . 


\section{THE COLLOQUIES AND THE MASS (1539m1541)}

\subsection{The Second Colloquy of Leipzig (1539)}

George Duke of Saxony had been an energetic opponent of the Reformation, particularly at the Diet of Augsburg in 1530. His territories, however, bordered on Utraquist Bohemia and were interspersed with the Evangelical territories of Electoral Saxony and Hesse. Delegates to the Estates of Ducal Saxony were familiar with the reforms which had taken place in the neighbouring territories, and, with increasing urgency, sought the authorisation of communion under both kinds and clerical marriage. The Duke's immediate heir was his son Frederick, a Catholic. Next in line was the Duke's brother Henry who showed increasing sympathy with the Reformation. The Duke's advisors feared that in the event of his death, Henry would make a bid to succeed his brother with the help of the Evangelical Elector John Frederick. ${ }^{1}$

Led by the Chancellor, George von Carlowitz, The Duke's advisors planned a programme of moderate Catholic reform by which they hoped to stave off internal pressure for more radical reform. They also attempted to neutralise external pressure through two religious colloquies with representatives of the neighbouring principalities. From 29th April to 3rd May 1534, an unsuccessful colloquy between representatives of Ducal and Electoral Saxony and the ecclesiastical Electorate of Mainz was held at Leipzig. The principal theological negotiators at this first colloquy were Melanchthon (representing Electoral Saxony) and the Dominican Michael Vehe (representing of the Archbishop of Mainz). 'The first Colloquy of Leipzig reached agreement on justification, however it collapsed after failing to reach agrcement on the Mass. ${ }^{2}$ It is worth noting that later in the same year, one of Duke George's coutcillors, Julius Pflug (1499-1564) wrote that the future of religious concord rested entirely on the Mass. The other controversial matters could, he thought, be dealt with easily, yet:

they deny that there is any sacrificial power in the Mass, except in so far as prayer for the church is associated with the Eucharist. Thcy

${ }^{1}$ See Wartenberg, "Die Leipziger Religionsgespräche von 1534 und 1539: ihre Bcdcuturng für die sächsich-albertinische Innenpolitik und für das Wirken Georgs von Karlowitz," in Die Religionsgespräche der Reformationszeit, ed., G. Müller (Gütcrsloh, 1980), 35-41; Augustijn, Die Godsdienst gesprekken, 16-35; Greschat, 177; Jedin 1:356; Pollet, Julius Pfing et la crise religieuse, 7981.

2 Pollet, Julius Plug et la crise reliyiense, 52; Sec Melanchthon's report to the Elector of Saxony, John Frederick, CR 2:722-726, esp. 723-724. Re. Vehe see, KTR 4:15-28. 
mean in other words that the Mass is not in itself a sacrifice which is beneficial for others. ${ }^{3}$

Von Carlowitz, arranged for a second colloquy to be held at Leipzig on 1st January 1539. This time he invited representatives of Hesse as well as those of Electoral Saxony. Bucer happened to be in Hesse at this time. In October 1538, the Landgrave Philipp had sought Bucer's help in winnning the support of Hessian Anabaptist leaders for the Landgrave's 1536 reform ordinance. Before Bucer's return to Strasbourg, Philipp also secured his services as a theological advisor at the coming colloquy. Bucer accompanied the Hessian Chancellor Johann Feige to Leipzig. Electoral Saxony was represented again by Mclanchthon and by its chancellor Gregor Brïck. Ducal Saxony was initially represented by the Humanist scholar and mayor of Leipzig, Ludwig Fachs and by Von Carlowitz. In the course of the proceedings, however, Witzel took Fachs' place as its theological representative. ${ }^{4}$

Lutheran hostility toward the apostate Witzel was such that Melanchthon refused to negotiate with him. The proccedings at Leipzig, which took place between 2 nd and 7 th January 1539, became a discussion between Witzel and Bucer. ${ }^{5}$ The result was sixteen articles which proposed a "true reformation" of doctrine and ceremonies drawing on the model provided by Scripture, right faith and the observation of the ancient apostolic church. ${ }^{6}$

There was, howcver, disagreement as to what constituted the "ancient apostolic church." Initially Von Carlowitz had proposed "the time of Gregory back to the time of the apostles." This was the time-frame covered in Witzel's Typus. Bucer and Melanchthon objected that there were matters inconsistent with Scripture on which all those in the time of Gregory had agreed. Here they specified apparitions of souls, Purgatory and "monkery." Von Carlowitz then proposed the time of Augustine as an upper limit. The Fvangelicals were not willing to give carte blanche to the beliet and practice of this period either. When Von Carlowitz complained that in so doing they had severed themsclves from the Apostolic church, they prolessed themselves ready to abide by the "chief articles" of the belief and practice of the ancients, but with the proviso that there must be full agreement

\footnotetext{
${ }^{3}$ Pollet, Julius Pflug: correspondince 1:346.

"For Witzel's account, see his Warer Bericbt (1562) in ARC 6:17-20.

${ }^{5}$ For Bucer's account, see Lenz 1:63-68, no. 23 \& Ein Christlich ongefabrlich bedencken... (Strassburg: [s.11.], 1545) (Stupperich, 79).

6 BDS 9.1:23. For the textual history of the German draft of the articles see the introduction in BDS 9.1:20-21. Michael Helding's Latin translation of the articles appears in ARC 6:1-17.

7 Puccr to Ptilipp of Hcssc, 2.1.1539 (Lenz 1:64, no. 23), "... wie die gewesen were von der zcit Gregorii zurtick bis uff dic apostel."
} 
on these. The "sophists," they said, had a way of perverting such agrcements." These may have been more Melanchthon's sentiments than Bucer's. It was Melanchthon, for example, who had attempted to warn the Fnglish against the "sophistry" of Gropper's Enchiridion. Howcver, as Bucer's later letters from Worms would suggest, he was not unwary of the dangers posed by ambiguous doctrinal formulations.

The Leipzig article on the, "sacrament of the body and blood of the Lord" began with a brief statement on the eucharistic presence: "[in the sacrament] the true body and true blood of the Lord are truly handed to us and poured out for us and taken under the species of bread and wine." The doctrine of concomitance was then defended. 'This seems intended to ensure that when the article later described communion under one kind as an "abusc," it was not seen to have any implications for the doctrine of the eucharistic presence. ${ }^{10}$ As Augustijn and De Kroon note, the terminology used to describe the eucharistic presence (onder der gestalt) is that of the 1530 Augustana invariata rather than the cum pane et vino formula of Melanchthon's Apoloyia, the Augustana variata and the Wittenberg Concord of 1536. ${ }^{11}$ However the annotations with Bucer's 1545 edition of the articles noted that gestalt was not to be understood to imply tratsubstantiation. ${ }^{12}$ As we have already noted, Witzel did not believe that transubstantiation should be an obstacle to unity in the church. However the choice of the invariata formula may indicate that Witzel shared in a widespread Catholic suspicion of the formula in the Augustana variata. We shall return to this question when we examine the articles of the Worms-Regensburg Book.

The definition of the eucharistic presence was followed by an account of eucharistic liturgy in the church of the "Saint Paul, the most ancient teachers and approved fathcrs." It noted that there had been always only one Mass celebrated in each church. After the reading of the Law and the Gospel, and after prayers and bymns the faithful, "made offerings to the Lord for the use of the poor." 13 Then, following the dismissal of the Catcchumens and the Sursum conda:

"Ibid., 67.

${ }^{9}$ BD5 9.1:30, "Von dem heyligen sacrament des leÿbs und Bluts Christi. In dem wurt vins warlich der ware leib vind das war Blut [sic] des herren vnder der gestalt Brot vnnd weins gegeben vnd genossen." Strangely, the blood is not mentioned in Helding's translation, "in hoc vere nobis corpus verum et vera caro domini sub specie panis et vini porrigitur" (ARC 6:6, 1, 2-3) possibly to defend concomitance.

${ }^{10}$ BDS 9.1:30, 1. 5-13.

${ }^{11}$ BS 64-65 \& 247-248 "...nos sentire, quod in coena Domini vere et substantialiter adsint corpus et sanguis Christi et vere exhibeantur cum illis rebus, quae videntur, pane et vino..."

${ }^{12}$ BDS 9.1:30, n. 37.

${ }^{13}$ Ibid., 1. 15-16, "...die opffer dem hern fur die armen gebracht..." 
the priest consecrated and distributed the holy sacrament with the words of the Lord about the offered bread and wine; he also reverently recalled the memory of the bitter death of Christ and his glorious resurrection and ascension, and in these prayers he set [furgestelt] Christ the Lord before God the Father for the sins of the faithful, that is, he prayed to the heavenly Father that ho would look upon the sacrifice of his Son made once on the cross, that he would receive it as payment and satisfaction for the sins of his people, and that he would be favourable and merciful to them. The ancients called this, "the immolation of Christ." "I'he people likewise dedicated, commended and offered thcir gifts, prayers and praises to Christ the Lord. This is why there is no thought among the ancient fathers of just one "offering" which is to take place in the celcbration of the Mass. ${ }^{14}$

Fere the pricst's memorial seems intended to echo the Canon's Unde et memores and similar extracts from Eastern eucharistic prayers collected in Witzel's Typus. The eucharistic prayer was followed by the sign of peace and the reception of communion under both kinds, first by the clergy and then by the people. The celebration was closed with thanksgiving and a blessing. ${ }^{15}$ It should be possible, the article stated, to celebrate Mass in any place and, "as often as it can take place in a way which builds up godliness among the people, [and] as long as trust in the opus operatum, the presence and participation of the unworthy and other abuses are excluded."16 The "other abuses" included the celebration of Mass without communicants and failure to explain the mystery of the Eucharist to the people or speak the words of the prayers audibly. ${ }^{17}$ The article advocated that all celebrations of Mass include an exhortation to receive communion as well as the restoration of an admonition by which the unworthy and those undergoing instruction in the fath were dismissed. Priests were to strive diligently to instruct the people in the meaning of the Mass. ${ }^{18}$

Beyond this measure of agreement, Bucer and Witzel appealed to the diversity of eucharistic practicc which they claimed had existed, "in the churches at the time of Saint Augustine." Once again this seems to be a reference to Augustine's Epistola 54 to Januarius. ${ }^{1 \%}$ The churches which held Masses only on Sundays and

${ }^{14}$ Ibid., 31, 1. 1-11 “... daher bey den alcen Vätern nit von einerley opffern, so in halten der. messen gescheen soll, gedacht wirdet."

${ }^{15}$ Ibid., 31, 1. 11-16.

${ }^{16}$ Ibid., 31, 1. 17-21 "... allein das man das vertrawcn vffs opus operatum, auch das vnwirdig bey sein vnd entpfaen der heÿligen sacrament sampt allen mißbreuchen vleyssig verhutet..." $\mathrm{Cf}$ ARC 6:6, "... sumptio indignorum ct reliqui abitsus exludantur..."

${ }^{17} \operatorname{BDS} 9.1: 31,1.21-32,1.3$.

${ }^{18}$ Ibia., 34, $15-24$.

${ }^{19}$ Ihid., p. 32, 1. 17-p. 33, 1. 9. See above, ch. 3, p. 31, ch. 6, p. 110. According to Wartenberg, 37, Von Carlowitz had senc a memorandum to Philipp of $L$ lesse in 1537 proposing the co-existenc: of the Lutheran and Roman rites, at least pending the decision of a general council. 
feast days (i.e. the Reformation churches) were not to be condemned. ${ }^{20} \mathrm{Yet}$, while the cclcbration of Mass without communicants had been described as an abusc, there were a number of clauses from the Catholic side which sought the daily celebration of a public, sung Mass even where it could not be guaranteed that communicants would present themselves. ${ }^{21}$ Those who did not communicate bodily, claimed the Catholics, might also communicate spiritually. ${ }^{22}$ The Evangelical side replied that this was a mutilation of the Sacrament in which Christ had instructed the faithful to take and eat. ${ }^{23}$ Despite this, the parties agreed to disagree and to work to preserve the common ground. ${ }^{24}$

The veneration of the saints and the commemoration of the dead were dealt with separately from the Eucharist. This reflects the separation of the two questions in Witzel's Typus. The article "on the veneration of the dead saints" distinguished between the commemoration of the saints, and the invocation of the saints. It alleged that the ancients had practised the latter only when in rhetorical overdrive. ${ }^{25}$ 'I'he principal end of the ancient commemoration had been to promote imitation of the saints. A secondary end had been to ask God that to hear the prayers made by the saints on our behalf. The article recommended that faithful commemoration of the saints replace direct invocation of them since the latter tended towards idolatry. ${ }^{26}$ An exceptionally brief article on the memorials of the dead recommended only that these be hcld in an honourable and devout manner. Here whatever promoted true godliness and had been decided by common consent was to be retained. ${ }^{27}$

${ }^{20}$ BDS $9.1: 32,1,10-16$.

${ }^{21}$ Ibid., p. 34, 1. 25-p. 35, 1. 4. Neither side is well-disposed toward private Masses. The Catholic side simply wishes to preserve daily, sung missac publicae. See ibid., 33, 1. 26-34, 1. 1, "Dann sie erst dartor achtern, wo man die Missen teglich halt, doch allein die offentlichen gemeinen gesunger enpter, das man die leuth damit baß zur kirchen pringen vnnd auch zu recht gleïbiger gedechtnus des tods Christi anrcitzen muge..."

${ }^{22}$ Ibid., 34, 1. 4-8.

${ }^{23}$ Ibid., p. 35, 1. 11-p. 36-1. 3.

${ }^{24}$ Ibid., 36, 1. 8-13.

${ }^{25}$ Ibid., 47, 1. 24-33, "Jn etlichen predigen aber der alten findet man, das sie erhitzigt auß jrem lob, die rede auch zu jnen gewarli vnnd sie gebcten haben. das ist aber ein prosopopoeia gewesen..." Prosopopeia is personification (See BOL 2:57, n. 123). BDS 9.1:4\%, 11. 118 takes this to mean that in the commemoration of their deeds the dead person is addressed as if present personally.

${ }^{24}$ Ibid., 48, 1. 2-10.

${ }^{27}$ Ibid., 49, I. 113. 


\subsection{The Secret Colloquy of Worms (1540) and the Colloquy of Regensburg (1541)}

\subsubsection{Introduction}

On November 25th 154C, an Imperial religious colloquy bcgun at Hagcnau in the previous June, reconvencd at Worms. As we have already noted, this meeting had been promised to the League of Schmalkalden in the Recess of the 1539 Diet of Frankfurt. Through the colloquy, Charles V hoped to secure the League's support for a Turkish war and a respite from the threat of a religious war in Germany. ${ }^{28}$

The first task of the Colloquy of Hagenau had been to decide on the text to be used as the basis for a future colloquy. It became clear, however, that the collocutors could not even agrec on this. The Catholics argued that a discussion of every article of the Augsburg confession was unnecessary. The colloquy should exclude what had been agreed to in the Committee of the Fourteen, and concentrate on the disputed articles. ${ }^{29}$ Howcver, as Bucer's Per quos steterit (Sept. 1540) suggests, the Fvangelical negotiators were dissatisfied with the Catholic account of what had been agreed at Augsburg. ${ }^{30}$ Bucer referred, for example, to a document bandied about by some on the Catholic side and written by Eck. ${ }^{31} \mathrm{~A}$ scriptum Ecki from this period alleges that the Evangelicals and Catholics had agreed on precisely the view of the Mass rejected by Melanchthon in his letters and iudicia from Augsburg. ${ }^{12}$

The reconvened colloquy at Worms finally agreed that the Augsturg confession would serve as the basis for discussion. Negotiations lasted until 14 th January 1541. They were closed at the Emperor's behest. The reason given for the closure was lack of progress. ${ }^{33}$ In fact Charles $V$ was on his way to Germany. He had convoked an Imperial Dict at Regensburg for March 1541 and promised to present it with proposals for a religious settlement.

'These new proposals were the product of secret negotiations during the Colloquy of Worms. ${ }^{34}$ Early in December 1540, the Imperial Chancellor Granvelle had approached a small group of theologians considered sympathetic to a negotiated re-union. ${ }^{35}$ Granvelle hoped that, removed from the heat of the official Colloquy

\footnotetext{
${ }^{28}$ Zur Mühlen, 659-660.

${ }^{29}$ Honée, 25-29.

${ }^{30}$ See Per quos steterit (1540) (BDS 9.1:165-173).

${ }^{31}$ Ibid., 173.

${ }^{32}$ CR 3:1054-1059.

${ }^{33}$ A number of accounts of these proceedings are edited in ARC 3:196-357. In fact Eck and Melanchthon had reached agreement on original sin. See CR 4:32-33.

${ }^{34}$ T.enz 1:274, no. 101.

${ }^{3 !}$ Ibid., 274-275.
} 
and the scrutiny of the opposing camps, these men would produce an entirely new negotiating text. ${ }^{36}$ The two principal collocutors were to be Gropper and Bucer. Gropper was accompanied by Gerhard Veltwyck, a Humanist and secretary to Granvelle. Bucer was accompanied by Capito.

Granvelle summoned Bucer to a meeting on 14th December and put the proposal to him. Buccr, though sceptical, sought the counsel of both Jakob Sturm and Johann Feige. He was advised to proced. ${ }^{37}$ To avoid the appearance of having acted unilatcrally, Bucer obtained a pre-dated letter from the Philipp of Hesse authorising him to participate in the secret colloquy. ${ }^{38}$ In the letter Philipp authorised Bucer to speak as an individual but not as a representative of the Protestant Estates. ${ }^{39}$ Negotiations began on December 15 th and ended on December 31 st 1540 .

As Augustijn notes, we have few sources of information about what took place at the secret colloquy itself. ${ }^{40}$ The most detailed account is in the correspondence between Bucer and Philipp of Hessc. These letters also offer us some insights into Bucer's motives and expectations. Anothcr source of information is pamphlet skirmish in which Bucer and Gropper attacked each other during the attempted Refornation at Cologne. ${ }^{+1}$ Our main source, however, is the product of the secret colloguy: the Worms-Regensburg Book. ${ }^{42}$

The first draft of the book (or at least an agenda for discussion) was drawn up by Gropper. ${ }^{43}$ According to Lipgens, this draft was later published as a series of articles in Warbaffitige Antwort (1545) a defence of Gropper's conduct at Regensburg. This view has been contested. The apologetic intent of Warbafftige Antwort suggests that the articles represent Gropper's interpretation of the Worms-

${ }^{36}$ Granvelle also feared that the belligcrents in the Catholic party at Worms would leave the colloquy if they knew of the existence of negotiations with some hope of success. Sec Lenz, ibid.

${ }^{37}$ Len\% 1:269, no. 98, 274, no. 101; Bucer, De concilio, p2b.

${ }^{3 *}$ Augustijir, "L'Esprit d'Érasme," 278.

${ }^{39}$ Lenz 1:280-283, no. 103.

49 Augustijn,"L'Isprit d'Érasmc," 383.

${ }^{41}$ Bucer Von den einigen rechten wege.. 63-66; De concilio et legitime indicandis, p2b-p4a; Gropper, Warhafftige Antwort, 38b-39a. See alsv Gropper to Jodocus Hoetfilter, 14.12.1544 (CCath 32:351-358).

${ }^{42}$ The recent edition in BDS 9.1 (to which I have referred here) follows Augustijn (See "Bucer und die Religionsrespräche," 678; "The Colloquies with the Catholics," 110) in distinguishing between the the final draft produced by the secret colloquy (the "Worms Bools") and the final draft presented to Charles V at the end of the Diet of Regunsburg (the "Worms-Regensburg Bools"). In the latter, for example, the fifth article on justification from the formor (BDS 9.1:397401) has been completely reworked. BDS 9.1:323-183 contains Latin and Gcrman version of the Worms-Regensburg Book (collated with the variants and additions from the editions published by the collocutors). Uncorrected German draft of Worms Book is in Lenz 3, no. 31-34. Latin version of Regensburg Book in CR 4:190-238. Latin version of Worms Regensburg Book in ARC 6:21-88.

${ }^{43}$ Lenz 1:532, suppl. 4, no. 7. 
Regensburg Book - one which he clained Bucer had pretended to share. ${ }^{44}$ There are certainly verbal echoes of Gropper's Enchiridion in the Book's article on the Mass. On the other hand, the articlc contains ambiguities and matcrial not found in the Encbiridion. 'Thus, although, Groppor's influence is evident - probably predominant - it is difficult to delimit exactly wherc his contribution ended and that of Bucer and the other collocutors began.

After the colloquy had finished its final draft, a copy was sent in secrct to Philipp of Hesse. The Landgrave was asked to examine it with some of his theologians. ${ }^{45}$ Philipp returncd an enended text to Granvelle. ${ }^{46}$ In Regensburg on Apri1 23rd 1541, the book was shown to the papal legate Cardinal Contarini by the Emperor's agent Louis de Praët. Over the next two days, Gropper assisted the legate and Cardinal Morone, papal nuncio to the Imperial court, in reading over the text. It was then handed back to the Emperor with twenty further corrections. ${ }^{47}$ This corrected draft was presented to the Colloquy of Regensburg on 27 th April 1541 as the work of certain leartned (but deceased) theologians from the Low Countries. ${ }^{48}$

The Eucharist was considered under different aspects in three of the Book's articles. Article Fourteen, On the sacrament of the Eucbarist, dealt with the of the consecration of the sacrament and its effects in faithful communicants. Article Twenty set out, Ceriain teachings which bave been affirmed on the anthority of the church. Among these were the veneration of the saints and the sacrifice of the Mass. Article 'Twenty-one, $O n$ the use and administration of the sacraments and certain specified ceremonies dealt with the private Mass, the administration of conmunion under both kinds, and the language of the celebration.

\subsubsection{Article Fourteen: The Sacrament of the Eucharist}

Before we examine the article on the sacrifice of the Mass, it is worth pausing to consider the contents of Article Fourteen and the debate surrounding it. Here, already, we see evidence of misunderstandings which would come fully to

${ }^{44}$ Sce RIOS 9.1:329, n. 35 and C. Augustijn, Godsdienst gesprekeen, 61, 11. 6; Braunisch, "Die 'Artikell' der 'Warhafftigen Antwort' (1545) des Johannes Gropper: zur Verfassertrage des WormsRegrensburger Buchcs (1540/41)," in Von Konstanz nach Trient, ed. R. Baümer, (Munich, 1972), 519545; Tipgens, 124.

${ }^{45}$ Lenz 1:291.

${ }^{46}$ Philipp also suggested that I.uthcr's comment on the draft be sought through Joachim II, the elector of Brandenburg, though without giving Luther any idea of the text's origin. See ARC 3:341-343.

${ }^{47}$ Matheson, Cardinat Contarini, 101.

4h Eck, Apologia 12a. The collocutors were Melanchthon, Bucer and Pistorius for the Protestant Estates and Eck, Gropper and Pflug for the Catholics (Augtstiijn, Godsdienst gesprekken, 80). 
light during the attempted Reformation of Cologne, Bucer's contribution to the debate among the Evangelical theologians at Regensburg also sheds light upon his broader approach to the Mass.

On 2nd May 1541, the Colloquy reached its well-known agreement on justification. Discussion on the sacrament of the Eucharist began on May 5th. The article drafted at Worms had described Christ's presence in the Eucharist as follows: "... after the consecration, the true body and the true blood of Christ are truly, substantially present and are distributed to the faithful under the species of bread and wine." ${ }^{39}$ After "bread and wine," however, Cardinal Contarini had inserted the phrase, "which of course - i.e. the bread and wine - have been transmuted and transubstantiated into the body and blood of the Lord."

It is usually argued that here Contarini was concerned less about transubstantiation than the authority of ecumenical councils; in this case Lateran IV. ${ }^{51}$ Clearly conciliar authority was importart to Contarini, but it would be wrong to think of his insistence on transubstantiation as secondary. As Fraenkel points out, the interventions at the Colloquy by Contarini and Eck suggest that both regarded the formulae of the Concord of Wittenberg and the Aurgustana variata as a slippery slope leading from Lutheranism to Zwinglianism. ${ }^{52}$ This is evident, Fraenkel argues, not only from remarks the two men made at the time, but from a sudden interest among theologians on both sides in the adoration, circumgestation and reservation of the host. ${ }^{53}$ None of these practices had been mentioned in Article Fourteen, but for Eck and Contarini, they had become a way of smoking out the "heresy of Berengar." Adoration of the host would be idolatrous unless Christ was truly and substantially "in and under" the element of the bread. Alrcady a report of the Catholic negotiators at the official Colloquy of Worms had characterised those who subscribed to the cum pane formula of the Variata as, "new Arians" concealing their denial of catholic truth with tricks of language. The report described the unter der Gestalt formula of the German Invariata as "catholic." However, although the Variata was said to have the appearance of truth, the report described it as a "Berengarian subterfuge" concealing its proponents' belief that Christ's hody was in

\footnotetext{
19 BDS 9.1:437, 1. 13-15, “... post consecrationem verum corpus et verus singuis donini vere et Substantialiter adsint et fidelibus sub specie panis et vini distribuantur."

5e Ibid., n. v) "... illis nimirum hoc est pane et vino In corpus et sanguinem doninj transmutatis et transubstantiatis d[istribuantur]."

${ }^{5 l}$ See e.g. Matheson, Cardinal Contarini, 122; Gleason, Gasparo Contarini: Venice, Rome and Reform (Berkley, 1993), 236, n. 212; Melhatusen, 189.

${ }^{52}$ Variata (BS 6.5) "...quod cum pane et vino vere exhibeantur corpus ct sanguis Christi vescentibus in coena domini"; Concord (ibid.) "...cum pane et vino vere el substantialiter adesse, exhiberi et sumi corpus Christi et sanguinem..."

${ }^{53}$ Fraenkel, "Protestants," 81; Cf Concord (BS 65) "Nam extra usum, cum asservatur in pixide aut ostenditur in processionibus, ut lit a Papistis, sentiunt non adesse corpus Christi."
} 
heaven and so could not be in many places on the earth - let alone "truly and really" in the sacrament. ${ }^{54}$ Contarini's dispatches from Regensburg show that he was well aware of such distinctions. ${ }^{55}$

After two days of fruitless debate, the parties met separately to find a new formula agreeable to both sides. Gropper and Pflug produced a reformulation of the article which called transubstantiation a "not unsuitable or improper" description of the "divine transmutation" of the bread and wine. This statement was made cum improbatione Berengarii so as to exclude a Zwinglian view of a sacrament. ${ }^{56}$ It appears, however, that neither Gropper nor Pflug shared Contarini's slippery-slope approach to the new Evangelical formulae. ${ }^{37}$ For this reason they refused to absolutise transubstantiation as the only possible explanation of substantial change. ${ }^{5.8}$.

Fraenkel has published an account of the meetings between theologians and Princes of the League of Schmalkalden between the 5th and 10th of May, together with minutes of discussions among the theologians on 7 th and 8th of May 1541. ${ }^{59}$ Of all the theologians whose contributions are recorded, only Bucer and a Johannes Rierer, theologian to the Margrave George of Brandenburg, show any inclination to engage in some form of compromise on the encharistic presence. On the question of transubstantiation, Bucer maintained that the term could not be held to be necessary for salvation. He adduced the support of Luther, the Scripture and the fathers who, he said, continued to call the bread, "bread" after the consecration. He condemned the circumgestation of the host and its adoratjon as "manifest idolatry." However he argued that if the Catholics were to admit no idolatry other than this, and were to admit a "just reformation" in their territories he could not exclude them from the lingdom of God. On the reservation of the species, he was prepared to allow that a diversity of practice might prevail as in the early church. These "fantasies" of the Catholics might be borne with, if they did not attempt to reimpose them on the Evangelical churches. He noted that the sacrament was also

${ }^{54}$ ARC 3:308, 1. 33-309, 1. 26. According to Hazlett, Development, 387-388, this accusation had precedent in the Sorbonnist Robert Ceneau's attack on the variation in Evangelical eucharistic doctrine De coena domini (1534). See also Adversus Axioma, H2b.

is Historisches Jabrbuch der Goerres-Gesellschaft 1:376ff, "ct dicono queste tre propositioni... la prima è chè ... ancora che ci sia Christo presentialmente ci resta pero la sostanza del pane e del vino, la qual fu nel principio positione di Luthero, ma parea pai che fosse sopita; la seconda propositione è che Christo sia nel sacramento solamente quando si usa... onde si avanza dopoi dicono che lì non ci è pitu Cliristo; la terza propositione è... che Christo non si deve adorare in quel sacxamento; queste due ultime propositioni per quanto io credo hanno aggiunto per conformasi in parte con li sacramentariï": quoted in Fraenkel, "Protestants," 80.

${ }^{36} \mathrm{CR}$ 4:261-262.

${ }^{57}$ Fraenkel, "Protestants," 86.

${ }^{56}$ DS 877, "Quae conversio convenienter et proprie ... transsubstantiatio est appellata."

${ }^{59}$ Frnenkel, "Protestants," 29-116. Another account ir Lenz 3:16-31. 
treated with signs of reverence such as the raising of hands and genuflection in the Evangelical churches. ${ }^{60}$

Doctrinally, Bucer did not differ from the other Evangelical theologians. What distinguished his attitude from theirs was his belief that Catholic eucharistic practices could be tolerated, provided that the life of the church in Catholic territories could be reformed in other respects. However, it is important to notice that Bucer did not seem to regard this toleration as permanent. He asserted that, "there can be no permanent peace unless our adversaries abandon this term 'transubstantiation." ${ }^{\prime 61}$ The best explanation of Bucer's approach lies in a remark made by Philipp of Hesse as he attempted to win the support of two intransigents Musculus and Brenz - for a policy of toleration:

...it seemed to him, and to several good men who came to him today, before and after lunch, that there were many good men among our adversaries who could gradually be won over through tolerance; especially the Emperor, [Louis de] Praët, Gerhard [Veltwyck], the bishops of Augsburg, of Cologne, of Eichstätt, of Bamberg ctc. - not that we must approve of their errors or justify them or reintroduce them in our churches; however, we should tolerate them as if still weak and not condemn them. ${ }^{62}$

It appears that Bucer had won the Landgrave's support for his attempts to accommodate the weaker brethren.

It is also worth noting Calvin's remarls that Bucer and Melanchthon had, "composed ambiguous and spurious formulas on transubstantiation, to try to satisfy our adversaries without giving anything away..." "Two of the documents which emerged from the meetings of the Evangelical theologians sought to appropriate the language of "transmutation," used by Gropper and Pfiug. The Censura $D$. theologorum nostrate partis stated that:

we affirm that the body is truly present and yet the bread is converted or changed in mystical fashion; i.e. one by which a true representation [exhibitio] of the present body takes place after the consecration. We

\footnotetext{
"Fraenkel, "Protestants," 102-106. Bucer was also concerned that intransigent rejection of transubstantiation would be ill-timed at this stage in the regotiations. Sec CK 39:215 and Lenz 3:21.

${ }^{61}$ Fraenkel, "Protestants," 103, "Verum non posse fieri solidam concordiam nisi adversarii transsubstantiationis vocabulum abiiciant."

${ }_{62}$ Ibid., 113, "Videri tamen sibi, et alicuot bonis quibusdan viris, qui hodie ante et post prandium ad se venerint, quod multi boti sint iriter adversarios, qui possint sensim per tolerantiam lucrifieri, ut pote Caesurem, Pratum, Gerhardum, Episcopos Augustensem, Coloniensem, Aistetensen, Bambergensem etc. Non quad nos debeamus ipsorum errores approbare, itustificare, vel acceptare et in nostras Ecclesias reducere, sed ut eos veluti adhuc inftrmos toleremus nec condemnemus."

${ }^{63} \mathrm{CR} 39: 217$.
} 
understand this mystical change to be not only one of signification, but onc by which the body of Christ becomes present. ${ }^{\text {st }}$

Another anonymous document, the Antigrapbe dia tou 7ma myos Maij conscripta, stated that a "more convenient" name for the transmutation would be "transconditionation.". Musculus's minutes of the discussions on the 8th of May report Bucer's opinion that, "we can admit that in the Supper there is a great change of a kind in the bread in so far as the bread is taken for the enjoyment of spiritual nourishment." "6́ "Transconditionation," may thus have been Bucer's contribution to the debate at Regensburg.

As the relationship between Gropper and Bucer became embittered in the course of the attempted Reformation at Colognc, it would become clear that the substantial presence of Christ "on the altar" by means of the consecration was a sine qua non of Gropper's understanding of the eucharistic sacrifice. In his own later commentary on the articles of the Worms-Regensburg Book in the Wabrbafflige Antwort, Gropper protested that he had not understood at the time that Bucer intended to, "re-introduce the heresy of Berengar." As we shall sce, Buccr would continue to insist that cven transubstantiation could be accepted as a description of the eucharistic presence if understood in what he believed to have becn its original sense: the change or conversion of the elements into sacraments.

\subsubsection{Article Twenty: Certain Dogmas Confirmed by the Authority of the Church}

By the time the Colloquy of Regensburg considered the articles on the invocation of the saints, the sacrifice of the Mass and the use and administration of the sacraments (Articles Twenty and Twenty-one) it was clear to everyone that no successful outcome was possible. Melanchthon summarised the final days as follows:

${ }^{64}$ CR $4: 263$.

${ }^{6.5}$ Fraenkel "Protestants," 103, n. 23 "... et quoniam in coena Domini corporalis illa panis ac viat conditio in spiritualen conditionem transfertur, convenientius transconditionationis quam transubstantiationis yocabulum."

un Ibid. 103, "... confiteri quidem nos magnam aliquam mutationem panis in caena, quod terrenus panis in spiritalis alimoniac usum sumitur."

67 Warbaffige Antroprt 84b, "Etiansi non esset damnatum in Berengario, quod is [i.c. Buccr] omnium postremo (ut erat inconstantissimus) asseruit, quod \& deinde in Concilio Romano [i.c. the Ego Berengarius of 1059 in Decretum Gratiani 3 de consecr. dist.2 c.42 (Friedbcrg 1:1328-1329)] cam ob rem indicto, licet infide abiurauit, videlicet, cum pane \& $x$ uino exhiberi corpus \& sanguinem Domini (uti \& articulus iste Protestantiun continet) tamen neque scriptura, neque Catholica loquendi formula in Ecclesia recepta, sic habet. Certe Christus discrte ait: Hoc (nimirum indicans idipsum quod ostendens in manibus tenebat) est corpus meum. Non dixit: Hoc est corpus meun cum pane \& uino." 
We came to the topics of the power of bishops, the invocation of the saints, the offering made in the Lord's Supper or "the application of the Mass," as they call it. Because it was impossible to agree on these matters, the opposing opinions will have to be submitted [i.e. to the Emperor and Diet]. Eventually, having given up hope of conciliation, we sped through the rest of the book ${ }^{68}$

Eck, who had led the Catholic side in the debate on the sacrament of the Eucharist, was "taken ill" (he had drunk too much) during the debate on the Mass." Gropper had his moment to shine. Cruciger reported sourly:

Our people are conferring with Gropper from Colognc. Hc is no less persistent and annoying [i.e. than Eck], but in another way: he is complctely drunk, pickled, dazzled and demented with the opinions of the church fathers, whom he inagines he has completely consumed, and comes here equipped with their weaponry. We, however, have recourse to another defence: the Word of God, which is invincible even against the gates of $\mathrm{H}$-ell. ${ }^{\text {ro }}$

Whatever Cruciger thought, Contarini was impressed. He reported to Rome:

They then discusscd the Mass and the Canon, in which context there was talk of the invocation of the saints. Gropper certainly gave great satisfaction, and dissolved their objections so well, that Bucer said, "I, for my part, would admit the Canon." ${ }^{31}$

At the end of the debate on Articles Twenty and Twenty-one the Evangelical theologians submitted two "counter-articles," as they had already done for article fourteen, and other articles on which no agreement had been reached. Counter-article "B" dealt with the sacrament of the Eucharist, " $G$ " dealt with the Mass, and " $\mathrm{H}$ " advocated the abolition of the private Mass and the rcstoration of communion under both kinds. ${ }^{72}$ The counter-articles were attached to the final draft of the Worms-Regensburg Book re-submittcd to the Emperor at the end of the Colloquy. While some of the other counter-articles had engaged with the content of the book, counter article " $G$ " is no more than a summary of the material from

${ }^{B S}$ CR 4:332-333.

6.) $\mathrm{CR}$ 4:306.

${ }^{70}$ Ibid.

${ }^{11}$ To Cardinal Farnese, 23.5.1541 (F. Dittrich, cd., Regesten und Briefe des Cardinals Gasparo Contarini (1483-1542). (Braunsberg: Verlag von Huyes Buchhandlung, 1881), 327), "I-Ianno poi conferito dellia messa ct del canone, dove si parto etiam dell'invocation [sic] de Santi. Il Gropperio certamente ha satisfato bene, et sciolse loro obietioni talmente, che il Bucero disse: Io per me admetteria il canone."

${ }^{72}$ See CR 4:352-354, 370-374. 
Melanchthon's Apologia which at certain points it repeats verbatim. 'This may suggest that the book's passage on the Mass was considered so ambiguous that it called for an unambiguous re-assertion of the Evangelical position. It may also be the case that critical engagement with Article Twenty seemed pointless once negotiations had broken down.

Article Twenty began by listing a number of dogmas which, "are conlirmed and established by the authority which the church enjoys both in the interpretation of Scripture and dogmas and in the establishment of ordirances." said, were received as divinely revealed (divinitus tradita). These were the Apostles' Creed, the relationship between the persons of the Trinity, the nature and person of Christ, original sin, infant baptisn, et similes. ${ }^{74}$ The article then gave detailed attention to threc further dognas: the veneration of the saints; the veneration of images; and the Mass, "which the wholc church agrees to be a sacrifice, though an tabloody, spiritual one." It is noteworthy that none of these three was included in the category of dogmata veluti divinitus tradita. Implicitly at least, the Mass belonged to a second rank: "received on the same authority" (i.e. of the church) but not neccssarily divinely revealed. In this way sacrifice need not be seen as intrinsic to the institution of the sacrament. Eck would later object to the location of the discussion of the Mass in the book. It suggested to him that the eucharistic sacrifice, invocation of the saints and veneration of images had no foundation in Scripture, and were no more than philosophers' opinions. ${ }^{75}$ Even Trent, howcver, would discuss the sacrament of the Eucharist and the sacrifice of the Mass separately. Nor, as we have noted, had thcre been any previous conciliar definition of the Eucharistic sacrifice. ${ }^{7}$ For this reason it is difficult to know what significance should be read into the separation and dogmatic ranking of the eucharistic sacrifice in the Worms-Regensburg Book.

\subsubsection{The Sacrifice of the Mass}

The book divided the Mass in to four "spiritual" sacrifices: (1) the sacrifice "of Christ" himself; (2) the church's self-offering; (3) the sacrifice of praise; (4) the church's gilts of bread and wine. In the Mass all four were offered to God, "provided that everything is performed in a godly and devout manncr." ${ }^{n 7}$ If, as

${ }^{73}$ BDS 9.1:452, 1. 16-18.

${ }^{74} \mathrm{Ibid}, 1.19-23$.

75 Eck, Apologia N1b, "... quasi illa non haberemus quoque ex scripturis, sed voluit Lutheranis adulari \& dognata appellauit, ac si essent philosophorum placita, ant Hippocratis decr'eta..."

${ }^{76}$ See above, ch. 2, p. 12.

${ }^{77}$ BDS 9.1:461, 1-3, "Adhacc onnis Ecclesia missam, in qua verum corpus et verus sanguis christi conficitur, sacrificium esse conscntit, sed incruentum, spirituale. In ea enim, modo pie et 
Lipgens believed, the articles published in Gropper's Warbaffige Antzort, were the draft for the secret colloquy, then the four-sacrifice-structure was Gropper's. ${ }^{78}$ However, no such structure appears in Gropper's Enchiridion. If anything, the division of the Mass into four offerings is alien to the Enchiridion's emphasis on the unity between Christ's sacrifice and those his body. In Adversus Axioma catholicum, however, Bucer had described the Lord's Supper as the "highest sacrifice, not only of praise, but of Christ himself, and also of ourselves." ${ }^{\prime 79}$ As we shall see, it may be that the fourth sacrifice of bread and wine was added to these three by Gropper. In this way Bucer's three sacrifices would be bound into Gropper's understanding of the Mass as a liturgical progression in which the symbols of the church's sacrificia pietatis were transformed into the sacrifice of Christ inaugurated in the Supper.

\section{at The First Offering: Christ}

The first offering in the Mass was that of Christ. He who offered his body to the Father on the cross as a victim sufficient for the sins of the whole world, was immolated to God the Father, in the name of the whole church, in the representative sacrifice of the Mass. ${ }^{80}$ His offering on the cross was made once and could not be repeated; however the power of the victim immolated endured forever so that today the sacrifice was, "'no less efficacious in the sight of the Father,' in those who represent it with devout faith, 'than on that day on which water and blood flowed from his sacred side." The church, "sets him [i.e. Christ] and his true body and blood before God the Father with prayer for the sins of the whole world and on account of this victim it prays for the temission of sins and the grace of God." ${ }^{11}$ As we have already noted, Eck's 1542 Apologia objected to the Article's claim that Christ's sacrifice was "no less effective" in the Mass than on the cross. The quotation came from Ps.-Cyprian, De baptismo Christi by way of Gropper's Enchiridion. $^{\text {82 }}$

religiose agratur, Dco quatuor spiritualiter offeruntutr."

${ }^{78}$ Sce BDS 9.1:493.

7 Adverstis Axioma, F2a, "Itaque existit in sacra coena summun sacrificium non laudum modo, sed ipsius Christi, sed et nostri ipsortum."

${ }^{60}$ BDS 9.1:461, 1, 4-8, "Initio enim cluristus, qui seipsum patrj in martalj corpore cruentam, sufficientem et beneplacentem pro totius mundi peccatis hostiam crucj affixus obtulit. Idem ille in missa, quae est omnium sacrorum sanctissima actio et publicum in Ecclcsia ministerium, totius ecclesiae nomine repraesentatiuo sacrificio eiden deo patrj Immolatur."

"B1 BDS 9.1:461, 1. 8-10, "Quod certe fit, cum Ecclesia illum eiusque verum corpus et sanguinem deo patrj pro totius mundi peccatis pia prece sistit" [Worms draft adds: "et proper hanc hostiam rexaissionem peccatorum et gratiam dei orat."] 'his is the only major cotrection to the Worms draft ol the material on the Mass. Its omission seems immaterial to either side's position.

${ }^{82}$ Ibid., 1, 10-13, "Nam ctsi oblatio illa in cruce semel facta transijt non reiterabilis, victima tamen ipsa Immolata perpetua virtute consistit, vt non minus hodie in conspectu patris oblatio illa In ijs, qui eam deo religiosa fide repraesentant, sit efficax quam eo die, qua de suo latere sangnis et aqua exivit." Ernaldus Bonaevallis, Liber de curdinalibus operibus Christi (PL 189:1631), "...non minus 
'I'he next paragraph noted that the fathers spoke of the body and blood of Christ, "present on the altar" as "the price for the sins of the whole world," "the price of our redemption" and, "the saving victim." ${ }^{35}$ Here the article cited the passage from Chrysostom's Homilia 17 in Hebraeos which had proved so popular in Catholic apology and so amenable to a Zwinglian view of the eucharistic memorial. The article continued: God had given his Son Jesus so that, "doubting our own powers and rightly conscious of our sias we may represent him to God the Farher as a unique, most powerful Victim who makes satisfaction for our sins." Here the article made an unattributed allusion to Bernard of Clairvaux's In Epiphania Donini sermo 1 and In Cantica 22, again via Gropper's Enchiridion. ${ }^{8+}$

How did Bucer understand these references to the "offering of Christ" and "representative sacrifice."? First of all, the "offering of Christ" meant for Bucer that Christ's sacrifice was commzemorated. Bucer's Consilizm theologicum quoted Augustine's Contra Faustum 20.21:

The flesh and blood of this sacrifice was promised before the coming of Christ under the likeness of victims. In the passion of Christ it was delivered up in truth itself. After the ascension of Christ it is celcbrated in the sacrament of the memorial. ${ }^{.5}$

This passage was also excerpted in the Florileginm patristicum where Bucer had underlined the words, "sacrament of the memorial." $\$ 6$

Howcver, the "representation" was more than mere memorial. In Adversus axioma catbolicum Bucer had written:

Aquinas affirms that the celebration of the Eucharist is called the "immolation of Christ" for two reasons: because it is, "a kind of

hodie in conspectu patris oblatio illa sit efficax, quam ea die qua de saucio..." Allusion not noted in BDS 9.1.

${ }^{83}$ 1bid., 1. 14-16, "In quam sententiam patres corpus et sanguinen christj in altarj praesentia nunc precium pro peccatis totius mundi, nunc precium redemplionis nostrac, nunc Victimam salutarein appellare consucuerunt."

${ }^{84}$ Ibid., 463, 1. 1-6. "...teus enim in hoc nobis donauit christum Jesum filium suum, Vt de nostris viribus diffisi deque nostris ieccalis nobis probe conscif, Tllum Velutj Vnicam et potissinam victinzaun pro nostris peccatis satisfactoriarn doo patrj represcntemus. Ipse enim natus est nobis, ipse datus est 1zobis..." Cf. Bernard, In Epiphariza Demini Sermo 1 (PL 183:144C) "Parvulus enim natus est nobis, et filius datus est nobis. De ue Dominie suppleo quod minus habeo in me..." \& In Cantica semo 22 (PL 183:882B) "...sufficicntia nostra ex Deo. Itaque cum defecerit virtus mea, non conturbor, non diffido. Scio quid faciam: calicen salutaris accipian, et nomen Domini invocabo..." See Encbiridion 106a and Antididagma 99. Allusions not noted in BDS 9.1.

${ }^{85}$ BOL 4:96, "Huius sacrificii caro et sanguis ante adventum Christi per victimas similitudinum promittebatur, in passione Christi per ipsam veritatem reddebatur, post ascensum Christi per sacramentum memoriac celebratur." Cf. PL $42: 385$ \& Oecolan1padius Ad Billibaldum Pyrkbaimerum, $22 \mathrm{a}$, where the same passage is cited as evidence of the equally representative nature of the sacrifices of the Law and the Eucharist which has succeded them.

${ }^{85} \mathrm{BOL}, 4: 29,11.4$. 
representative image of the passion of Christ,' and because the, 'effects of the passion of Christ' are received in it. 'This no-one on our side contradicts. ${ }^{\mathrm{k}}$

In Consilium theologicum he would quote Aquinas agait. The Fucharist "is called a 'victim' in so far as it contains Christ himself, who is the "saving victim." "88 The scholastics, wrote Bucer, called the Supper a sacrifice because it was a solemn commemoration of the passion of Christ and represented (exhibeat) him who offered himself once for us. ${ }^{89}$

Exhibitio had not had a "strong" sense in Buccr's carly sacramental theology. In the 1529 version of his John commentary, exbibere and repraesentare described the function of the sacraments, but in the context of an attack on the claim that external word and sign were instruments and means of grace and the Holy Spirit. ${ }^{\circ 0}$ In the 1530s, however, Bucer began to emphasise the objective conjunction between the outward word/sign and the inward grace offered in the sacrament's institution. Here exbibere acquircd a "strong" sense." Discussing circumcision, for example, his Romans commentary defined the ceremonies of the Old 'l'estament as:

certain actions and observances... which the Lord has instituted for his people for the following purpose: that in them, by means of the sacred ministry of his church, he may offer, bequeath and represent (exbibeat) a share of eternal life, as it were, to our senses, though in fact by means of a sign and confirmation suited to stirring us up... This is the logic underlying sacraments and all sacred ceremonies: not only those which were passed on to the Hebrews, but also those of the church of Christ who is now preached openly. 92

${ }^{87}$ Adversts Axioma, F3a, "Aquinas... affirmat celebrationem eucharistiac, "duplici ratione dici inmolationem Christi,' et quia sit 'quaedam imago representativa passionis Christi,' ct quia in ea percipitur, 'cffectus passionis Christi.' Hoc apud nos nemo contradici.." Cl. Aquinas, ST 3a q. 83 a.1.

${ }^{\text {s8 }} \mathrm{BOL}$ 4:96, "Dicitur autem "hostia' in quantum continet ipsum Christum, qui est bostiat salutaris." Cf. Aquinzs, ST 3 a q.73 a.3.

${ }^{89} \mathrm{BOL} 4: 95-96$.

${ }^{90}$ BOL 2:269, "Eant nunc illi novi Thonistae [i.e. Brenz and the Lutherans] et probent illa esse 'instrumenta et media' gratiae et Spiritus Dei, sine quibus illa interna dona Dei remini contingat. Nos libenter verbum şuod nos loquimur et sacramentum quod nos exhibemus, nihil nisi evanidum signum esse fatemur, si nos cooperetur Deus, id est animo persuadeat et donet quae nos ex ipsius verbis proponimus et sacramentis representamets."

${ }^{91}$ Bornert, 315ff; Hazlett, Development, 345.

${ }^{92}$ In Romanos, 152, "Proinde qui velit iuxta Scripturam sacras ceremonias definire in genere, is huiusmodi definitioncm dabit: Esse actiones \& obseruationes quasdam sensibiles \& significatiuas, quas Dominus suo populo instituit in hoc, vt ipse in illis, vsu sacro Ecclesiae suae ministerio communionem vitae aeternae, quasi sensibiliter, significatione nimirum \& attestarione ad excitandum nos summe idonea offerat, tradat, \& exhibeat... IFaec ratio est sacramentorum, vel sacrarum ceremonium omnium, non solum quac tradica fuere Ebracis, sed etiann quac Feclesiae Christi iam palam praedicati. Nemo enim ron fatetur \& hec signa esse, quibus aeterna vita cum 
It is clear from the Jobn commentary and elsewhere that Bucer regarded exhibitio and repraesentatio as synonymous whether their function was weak or strong. ${ }^{93}$ However, the strong sense of the words was "catabatic" in orientation (i.e. used to describe the movement from God to humans). As Bucer put it in the Consilium:

Provided that it is correctly administered, the offering of Christ is indeed commemorated in the Holy Supper, commended to the faithful and also represented to them in the dispensing of the sacrament. Thus the ancient church rightly and freely said that Christ is "immolated in the Supper" and called the Supper a "sactifice." However, they attributed the name "sacrifice" to the action [emph. Mine] of the Holy Supper, because the praises of God... and the things which the faithful brought there for the use of the poor were solemnly offered through the ministry. ${ }^{94}$

In the Worms-Regensburg Book, however, the indirect object of the "representative" sacrifice of the Mass was as much God the Father as the faithlul. The church offered Christ to God the Father (eidem Deo patri) in a representative sacrifice; it "set" Christ's body and blood before the Father with devout prayer. For all Gropper's "l'homism," his Enchiridion had used repraesentare not as Thomas in a catabatic sense but as Eck in an anabatic (i.c. Godward) sense. ${ }^{95}$

Bucer, however, had made provision for such usage in the account of sacrifice in his Romans commentary. The principal purpose of the sacrifices of the Law, he wrote, was the exbibitio and repraesentatio of divine benevolence toward humanity. Here Bucer hinted that the Eucharist was prefigured where the participants in the Old Testament sacrifices ate what they had offered. However, human beings had also offered external sacrifices so that they might "set" themselves before God to abtain forgiveness of sins and favour. In such sacrifices the priests had acted "in the person of Christ the mediator" bearing witness that

significando cxhibetur, tum exhibendo significatur." See also Bericht (BDS 5:160, 1. 5-9); Aquinas, ST 1a 2ae q.102 a.3 \& 2a 2ae q.85 a.1.

${ }^{93}$ This is borne out elsewhere in his writing. See e.g. Pollet, Études 1: 268, 1. 10-15.

${ }^{24}$ BOL 4:94-95, "Est quidom in sacra caena, dum en rite administratur, oblationis Christi, qui in Cruce stmetipsum pro nobis obtulit commemoratio et ad fideles commendatio, tum ctiam dispensatione sacramenti exhibitio: ut recte vecus ecclesia 'immolari in caena Christum' libenter dixeril, caenam ipsum 'sacrificiun' vocarit. Quamquam ideo sacrificii nomen actioni caenae sacrac tribucrunt, quod in sacra coena laudes Dei, et quae fideles illic Domino ad usus pauperum conferunt per administrum caenae solemniter offerebantur."

${ }^{95}$ Enchiridion 107a, "Idcirco ecclesia per sacerdotem, vt publicum ministerium Christi corpus in missa offerens, non tantum hoc agit vt corpus Christi verum, illiusque passionem quae praterijt, deo repraesentet, sed \& seipsam (quae Christi capitis mysticum corpus est) per Christum. offerat." 
those who offered were pleasing and dear to God. ${ }^{96}$

This echoes Augustine's account of Christian sacrifice and its relationship with the sacrifices of the Natural and Old Laws in De civitate Dei 10.6 and 10.20. Both passages were quoted in full in Adversus Axioma catholicum. There Bucer also quoted part of the much-used passage from Chrysostom's Homilia 17 in Hebraeos. ${ }^{\text {"7 }}$ These passages, which described the faithful offering and being offered through and by Christ the High-priest and Mediator, were glossed as follows:

for when we receive the strength and fruit of what Christ offered in himself on the cross and share it with the brethren by means of the sacred ministry and the secret fellowship among the saints, we cannot but consecrate ourselves entirely to God, and zealously bear witness to this through generous alms-giving towards the least in the Lord."

While a passage such as this sits rather more comfortably with the new Evangclical cucharistic orders in which thanksgiving and alms were offered after communion, a passage in the Consilinm suggests that Bucer thought it could be reconciled with the order of the Roman rite:

nothing in the traditions and decrees of the fathers, nothing in these words which are said in the Mass, nothing in the teaching of the scholastics suggests other than that, in the Masses, one celcbratcs the memorial of Christ offered on the cross, and, as it were, [italics mine] sets Christ before the Father in the priest's prayers in the name of the whole church, so that Christ's faithful may enjoy the fruits of the sacrifice consummated on the cross. ${ }^{99}$

Again, this passage amounts to a gloss on Bucer's understanding of "representative sacrifice" when used in an anabatic or Godward sense. ${ }^{106}$ As we shall

${ }^{\prime \prime}$ In Romanos, 151-152 "In oblationibus \& sacrificijs, \& si offerrent aliquid homines, quia id tamen ideo faciebant, $v t$ se sisterent domino, remissionem peccatorum \& perpetulun fauorem exorarent: precipuum in his quoque scremonijs fuit exhibitio diuinae benevolentiae. 'lum quoque oblationes eiusmodi \& sacrificia perficiebantur, cum victimas ignis Dei absumpsisset: id vero pro visibili tescimonio crat, vt hostias, ita multo amplius eos, qui illas sacrificassent, Deo gratos charosque esse, id quod sacerdos eo etiam testabatur, cum a populo hostias $\&$ alia offerenda Deo accipeibat. Mediatoris enin Christi personam gerebat. Eadem diuinae beneuolentiae confirmatio \&: perennitas \& eo repraesentabatur, quod de quibusdam sacrificijs if quoque edebant, qui illa fecissent."

"Adversus Axiona, F2b.

${ }^{98}$ Ibid., F2n-F2b, "Eius enim, quond se Christus in cruce obtulit vim et fructun hic cum percipimus - turn fracribus pro modo sacri ministerii et arcanae sanctorum inter se socictatis communicamus; indeque non possumus nos non totos Domino conserrare, idque benignis elccmosynarum largitionibus, erga minimos Domini, studiose testari." sisti., "

"Consilinm (BOL 4:149), "... Christum Patri precibus sacerdotis, vice totius ecclesiae quasi

${ }^{10}$ Such a gloss is perhaps more evident in the German draft of the arricle which used Gott dem Vatter... durch widergedächtnul? and furstellung vnblatetig auffgeopffert for Deo patri... 
see, the figurative nature of Bucer's understanding of "offering Christ to the Father," - the quasi - would become unequivocally clear in the wake of the Cologne Reformation.

However, there was yct another phrase which biased the sense of Article Twenty in a Catholic sense. The second Colloquy of Leipzig had described the "immolation of Christ" as the priest's prayer that the Father look upon "the offering of his Son performed once on the cross." 101 "This could read figuratively: i.e. in reference to the cross as a past event only. It could also be taken to refer to the body and blood of Christ present on the altar sacramentally. In the WormsRegensburg Book the latter seems to have been intended: "the fathers called the body and blood of Christ, present on the altar, the price for the sins of the whole world..." To speak of the body and blood as in altari praesentia was to assert the objective presence of Christ in the elements irrespective of their reception by faith in communion. As we have noted above, the Consilium was careful to emphasise that the exbibitio of Christ's offering included the dispensatio of the sacrament. How, then, did Bucer understand the phrase in allaris praesentia? Again the answer would become apparent only in the wake of the Cologne Reformation.

\section{b The Second Offering: The Church}

The second offering in the Mass was defined as the church's offering of herself: i.e. of the mystical body of Christ which counted among its members not only the faithful still alive, but also thosc who had died "marked with the sign of faith" (an intentional echo of the Roman Canon). ${ }^{102}$ Through Christ the church rededicated to the Trather what Christ once dedicated to God in himself on the cross. ${ }^{103}$ In the sacrifice the church recalled that through his death Christ has dominion over the living and the dead. It remembered "those who fell asleep in the Lord and were not yet fully cleansed," and bore witness to the unity of the body of

repraesentatiuo sacrificio... immolatur (BDS 9.1:460), 1. 19. Furstellen is the verb used in the Leipzig formula to describe the priest's "setting of Christ beforc the Father."(BDS 9.1:31) ansehen..."

101 Ibid., 31, 1. 5-6, "... das er das opffer seines sons, an Creutz ein male bescheen,

${ }^{102}$ Ibid., 463, 1. 14-16, "... ramos suos in praeterita, praesentia et futura tempora extendit [i.e. ecclesia] et membra habct non tantum qui praesentem vitam adhuc ex fide Viuunt, sed etiam qui curn signo fidej praecesserunt..." Cf. Canon missae, Memento ctiam.

${ }^{103}$ Ibid., 1. 7-13, "Secundo Ecclesia in hoc missae sacrificio seipsam quoque, quatenus christi mysticum corpus est, per christum deo offerre non dubitat. dum enim ex immolatione christi semel in cruce peracta spiritualiter agnoscit nos in Vniversum omnes perditos esse, nisi per Vnicam illam hostiann reconciliatj seruemur, fit ut Vicissim se totam deo consecret et, quemadmodum Christus nos omnes in cruce portabat ct totius Ecclesiae causam gerebat, eam ith se ipso deo patri offerens, sic ecclesia tantam oblationcm pia deuotione recolens se totam per Christum deo Viuo vicissim dedicat." This final line also seems intended to echo Canon missae, Menento, Domine: "... tibiquc reddunt vota sua aeterno Deo, vivo et vero." Allusion not noted in BDS 9.1. Sec also Gropper, Encbividion, 107a. 
Christ which it had in this sacrifice. ${ }^{104}$ It also sought with these prayers, "to bring ease to those who in this life, through the merit of their faith, have obtained the possibility of thesc prayers being of benefit to them after their death." 105

The "memorial of the martyrs" was also mentioned in passing here. It had already been discussed with the veneration of the saints. In both places article twenty quoted Augustine's Contra Faustum 20.21: the church cclcbrated the memorial of the martyrs, "to stir up imitation of them and in order to be associated with their merits." ${ }^{106}$ Referring to the Roman Canon's prayer Communicantes (i.e. its first memorial of the saints) the arcicle stated:

since there is no doubt that the saints have their merits, which are, even so, themselves gifts, it has thus been received by the common consensus of the church that prayer is offered to God in the following manner: to grant that through, "the merits and prayers," of his saints, "we may be strengthened in all things by the assistance of their protection," not, of course, by their merits in themselves, but "through Christ our Lord" by whose grace they, too, were saved, and from whom they regard themselves as having reccived cvery merit. ${ }^{107}$

We have already noted Bucer's readiness in the Furbereytung to admit the language of "merit" understood as God's "crowning" of his own gifts. "The potential for rapprochement on this question had been explored at greater length in his Romans commentary. His labours bore fruit in the draft article on justification

${ }^{104}$ Ibid., 1, 17-24, "...recolit. Christum ob id mortuum semel, ut et tivorum et mortuorum dominetur, non se diuidit, sed veluti se totam colligens non solum presentium, [Cf. Gropper, Enchizidion 107h] sed et: sanctorum, quos iam cerco apud deum viuere nouit et aliornm quoque fratrum et sororum, qui in domino, sed non defecatj satis, obdormiuerunt, mominit as testatur se in hoc sacrificio Vritatem corporis Christi intelligere seque per fidem tum illorum, qui apud deum viuunt, socictati suauj communicatione copularj, tum caeterorum omnium in christo membrorun pia sollicitidine et caritate tangj ac tenerj."

${ }^{\text {so. }}$ Ibid., 1, 27-29 “ $\ldots$ sed et pro fidelibus defunctis in Vninersum supplicare atque adeo horum animas eituscemodj precibus subleuarj, cui tanen, Vt hoc eis post mortem prodesse possit, in hac Vita sibi per fidei meritum compararunt."

${ }^{106}$ Ibid., p. 453, 1. 24-p. 455, 1. 2, "Hac quoque auctoritate [i.e. ecclesiae] receptum est sanctos... laudandos ac eorum memoriam, ad excitandam imitationem vt meritis eorum consociemur, religiosa sollenitate colcbrandam csse, quemadmodun Augustinus habet contra Faustum Manichaeum lib. 20 cap. 21..."; ibid., 463, 1. 25-27, "Quamobrem patres testantur ecclesiam in eoxlem sacrificio non solum matyrum cun ad excitandam initationem, tum ut meritis eorum consocietur, religiose celebrare..." Cf. PL 42:384; Gropper, Enchiridion 110a; Bucer, Florilegiam patristicum 145 (BOL 3:59). We cannot be sure that Bucer came upon this sententia by way of Gropper or by some other route.

${ }^{107}$ BDS 9, 1:455, 1. 8-13 "Et ut non dubium cst sanctis sua esse merita, quae tamen etian Dei sunt dona, Ita communi ecclesiae receptum est, ut pie in hunc modum oretur Deus, quo sanctotum snorum meritis precibusque concedat, $v$ in omnibus suae protectionis muniamur auxilio, notn quiden ipsorum meritis ex se, verum por Christum dominum nostrum, cuius gratia et illi servati sunt, cui etiam omne meritum illi accptum ferunt." Cf. Canon Missae, Communicantes: "... quorum meritis precibusque concedas, ut in omnibus protectionis tune muniamur auxilio, per eundem Chrisum Dominum nostrum." 
written at Worms and in the version redrafted at the Colloquy of Regensburg. ${ }^{108}$

Melanchthon's Apologia had also allowed that the saints had "merits" in this qualified sense. Bucer, however, went further than Melanchthon. In the Consilizm theologicum he allowed a sense in which these merits could be said to assist the faithful. Like Melanchthon, he emphasised that the saints' memorial was celebrated to inspire imitation and thanksgiving for the wonders Christ had worked in them. He admitted, however, that this memorial might result in a cortaitr excessus animi, leading the godly soul to seek assistance through the saints' intercession, "as well as their merits which it [i.e. the godly soul] remembered had been so generously rewarded by God, not only in the saints themselves but also in many others for whom the saints were concerned." 109 God had promised to do good to those who loved him and kept his commandments to the thousandth generation (Exod 20:6). God's promise to answer the saints' intercession for the church could thus be counted among their "merits." According to Bucer, it was for this reason that the memorial of the martyrs had been accompanied by their invocation in the early church. Neither, however, had the cxpress warrant of Scripture. ${ }^{110}$

In a letter to Philipp of Hesse, Bucer mentioned four points over which Gropper and Veltwyck had been intransigent during the secret colloquy. Two were transubstantiation and the necessity of yearly confession. The other two were the memorials of the saints and "those about whose holiness we are apprehensive." was on these latter two counts that Gropper and Veltwyck were least ready to budge. ${ }^{112}$ They had conceded that the commemoration of the saints had no express warrant in Scripture. They also conceded that the direct invocation of the saints was the product of a "fervent disposition" (the prosopopeia of the Leipzig formula) and that it should not be practiced in the sacred liturgy (though they asked that it not be condemned). They appealed, however, to Groppct's ratio synaxeos: "that all of us, who believe in Christ, are members of his body and of each other and must

${ }^{10 y}$ See eg. Metaphrasis et enaryatio in Romanos 13, ".,rcliqui Patrcs, ita \& D. Augustinus admittit merita quidem, id est, bona upera in sanctis, quibus Deun mercedem est pollicitus. Qui dederit poculum aquae frigidae in noninc Christi, non carebit, mercede sua, inquit ipse Scruator. Paulus si volens Euangelium adrininistral, mereden expectat. Verum hace ipsa bona opera sanctorum, quibus Deus glorian rependit, iden dicit ipsius dei dona esse."; Cf. BDS 9.1:391, 1. 1729. In fact the word meritum would be replaced in the extensively redrafted fifth article of the Worms-Regensburg Book (BDS 9.1:9-12) by merces or "reward." Unlike "merit," "reward" was scriptural (e.g. Matt 6 passim).

${ }^{104}$ BOL 4:84, "Tum fit... excesstus quidam anini, ut illos quarnvis absentes pius animus ixvocet, et iuvari se apud Christum expetat cun corum intercessione (quam recogitat apud Christun olim - dum illi hic agerent - tantum valuisse) tum etiam eorum meritis, quae tam liberaliter meminit a Deo remunerata esse - non tantum in ipsis divis sed etiam in snultis aliss, quorum divi curatm agebant."

${ }^{110} \mathrm{Ibid},{ }^{84-85 .}$

${ }^{111}$ Lenz 1:288, no. 106.

${ }^{112}$ Thid., 289. 
intend and bear toward one another an eternal love to the praise of the Lord." "113 A conscquence of this love was that the saints pray for us and seek God's mercy for us - though always and only through the merit of Christ. ${ }^{114}$ Here, interestingly, Bucer quoted Exodus 20:6; the passage used in the Consilium. This suggests that it had been eited by Gropper and Veltwyck, though he may have added it himself in order to explain their views to the Landgrave.

How did Bucer understand Article Twenty's reference to the dead who were "not yet fully cleansed," and to the church's hope that it might "bring relief" after death to those who had procured it by the merit of their faith while still alive? 'the reference to meritum fidei etc. echoes Augustine's Enchiridion 110 which had been quoted in Gropper's own Enchiridion. It was also cited without comment in Bucer's Florilegium patristicum, and Fraenkel suggests that Gropper was Bucer's source. As we noted above, however, Augustine's Enchiridion 110 was common-place in Catholic apology. ${ }^{115}$ We have already noted that the practice of prayer for the dead was not problematic for Melanchthon, and trcated with some sympathy by Bucer in the early part of his career. In Consilizm theologicum Bucer argued that such prayers at the Eucharist could not be condcmned. Hc citcd another Catholic commonplace - Augustine's Confessions 9.11 - and concluded:

the devout mind cannot but commend its departed to Christ, and pray for the desired resurrection on which they wait. And what it does with devotion, it cannot but wish to be done by the whole church especially when the church is joined intimately with Christ her Lord and spouse in the celebration of the Eucharist. ${ }^{116}$

Further on, however, Bucer condemned the abuse whereby, "the antichrists give themselves permission to remit temporal punishment here and in Purgatory; a power which has been committed to them by no Word of God,"117 'This was accompanied by a condemnation of the:

abuse and perversity whereby the antichrists pretend that, "many in the church have exceeded the amount of works of penitence asked of them," and that these "supererogatory" merits are applied to those to

\section{${ }^{113}$ Ibid., 288.}

${ }^{11 \cdot 4}$ Ibid.

${ }^{115}$ Augustine Enchiridion 110 (PI. 40:283); BDS 9.1:463, n. 281 cites Augustine, De chra pro mortuis gerenda 1.1-2 (PI 40:592-593) which discusses similar ideas, but the use of the word "sublcvari" in the Worms-Regensburg Book points to the "relevari" in Augustine's Encbriliton 110. C. Gropper, Enchividion 110b-111b; BOL 3:157, n. 72

${ }_{116}$ BOL 4:42, "Non enim potest mens pia non commendare defunctos suos Christo, ot quam expectant ii optatam resurrectionem praecari; quoque ipse [sic] pie facit, non potcst non optare ab omni etiam ecclesia fieri - et tum maxime, quando illa cum Christo, Domino et sponso suo agit familiarius."; Cf. PL 32:775.

${ }^{117} \mathrm{BOL}$ 4:1C5. 
whom the pope grants indulgences, together with the merits of Christ. ${ }^{118}$

Here it should be noted that Bucer did not condemn the notion of Purgatory as such. Some room was left for Augustine's ignis purgatorius - just as long as this was separated from the complex of indulgences and supererogacory works. Moreover, in the same place, Bucer gave a sympathetic account of the development of the system of canonical satisfactions from which the system of commutations and indulgences had arisen, labente magis ecclesiae disciplina ${ }^{\mathrm{I}}{ }^{19}$

Bucer's account of the secret colloquy suggests that, like Witzel, Gropper and Veltwyck insisted on prayer and almsgiving for the faithful departed while admitting a latitude of opinion on the mechanics of such prayer. Sadoleto would later deal Gropper a gentle reprimand for not having made the connection between the canonical satisfaction and Purgatory clear enough. Gropper replied that although the Enchiridion contained no separate article on Purgatory, he believed the connection had been made clear in the chapter on the Eucharist. ${ }^{120}$ What was important for Gropper was that the ratio synaxeos compelled the church militant to pray for those with whom it awaited the resurrection of the body. No-one, however, should be compelled to believe in Purgatory. ${ }^{121}$ At Worms, Gropper and Veltwyck conceded that, like infant baptism and veneration of the saints, commemoration of the dead had no express warrant in Scripture, but was so old that it must be of apostolic origin. Again, they emphasised that wherever the church prayed in this way it was always through Christ and his merit. ${ }^{122}$ Bucer recorded these remarks without expressing any judgement on them.

Also noteworthy is Bucer's remark in another letter, that Gropper and Veltwyck were prepared to, "drop application and the intention of the massingpriest." ${ }^{223}$ For Bucer, the "church's self-offering" described only the priest's prayer of intercession on behalf of the people. For Gropper, however, it was also the

${ }^{118}$ Thid., "Altcra abusio et perversitas est, quod anticlaristi finxerunt "multos in ecclesia in operibus poenitertia supra mensuram debitorum suorum supererogare,' quae supererogata merita, conimneta meritis Christi per pontifices applicentur is, quibus indulgentias concedunt." $C$. Aquinas, ST 3a Suppl. q.71, a.10 or In 4 libros sententitrum dist. $45, \mathrm{q} .2$, a. 3.

1:9 BOL 4:104.

${ }^{126}$ Sadoleto's letter is reproduced in an appendix to Wrathaffige Antzert, 79b-18b. Gropper responded in a marginal note $(7 \% \mathrm{~b}-80 \mathrm{r})$ : "recte monet... tametsi si tamen in Enchiridio alibi, sed forsan non ita suo in loco multa \& celebris Purgatorij mentio, \& ex patribus comprobatio fiat sub titulo, De sacramento Eucharistiac..." I.e. in the passsage on the ratio synaxeos in Encbiridion, 72b. The relation between canonical satisfaction and temporal punishment is considered, ibid, 109b$112 \mathrm{~b}, 158 \mathrm{a}$. No mention is made of indtlgences. bekerincn..."

:26 Lcrz 1:289, "Dann, ob sie wol nun lsein fegfeur setzen und frei mit den alten vettern

${ }^{122}$ Ibid.

${ }^{123}$ Ibid., 286, "Die application und anlegung des meßmachers lasen sie dennoch fillen." 
priest's and people's faithful apprehension of themsclves and all the members of Christ's body as offered under the species of bread and wine following the consecration. As I suggested earlier, it seems likely that Bucer understood Gropper's "Thomism" as an abandonment of application.

\section{c The Third Offering: Praise}

The third sacrifice was praise: an end of the institution of the sacrament and the reason for the name "Eucharist." "Praise" was described as "faith, hope and love." ${ }^{124}$ It included spiritual sacrifices similar to the "eucharistic sacrifices" included in Melanchthon's Apologia. ${ }^{125}$ The article ended with the following words: "in the presence of such a great sacrament these are reclsoned more effective and to be worth more." This was supported with a quotation from Ps.-Cyprian, De coena domini:

in the presence of this most true and holy body tears do not beg pardon in vain, nor can the sacrifice of a contrite heart be spurned. Here the devout high-priest, representing the mystery of the cross with raised hands, prays confidently for recognition of his own ignorance and that of his people. ${ }^{126}$

We roted earlier Melanchthon's insistence that "eucharistic sacrifice" was not confined to the action of the Lord's Supper. Rather it referred to the whole worship of the New Testament. ${ }^{227}$ 'I'his reference to the special cfficacy of the Mass, and the eatlier description of the Mass as the, "most holy action of all the sacred rites," seem intended to safeguard Catholic belief in the sacrificial character of the Eucharist's institution. Here, though, the assertion was diluted somewhat by the

${ }^{124}$ BDS 9.1:465, 1. 1-5, "Tertio in missa sacrificium laudis, quae huius quoque Jnslitutionis finis cst, offertur, hoc est sacrificium fidej, spei, et caritatis, atque id inprimis gratiarum actionem complectitur, quam pro illo summo beneficio et nobis et veiuersae Ecclesiac collato porsoluimus, propter quam reuerenda et tremenda ista mÿsteria Eucharistia appellantur." Cf. Ps.-Augustine (i.e. Fulgentius of Ruspe) De fide ad Petrm PL 40:772, "... sacrificium parnis et vini, in fide ct charitate, sancta ecclesia... offerri non cessat..." See above, ch. 3, p. 61 \& helow ch. 4. p. 201. Allusion not noted in BDS 9.1.

125 BDS 9.1:465, 1, 6-9, "gratiarum actioni communicatio et confessio doctrinae, obsecrationes, orationes, postulationes et preces pro omnibus hominibus et pia vota, sacrificia certe spritualia et deo grata coniuncta surtt..." Cf. BS 356, but there is also a clear reference to the Catholic commonplacss 1 Tim 2:1 and Augustine, Epistola 149.2. 12-16 (PL 33:635-637). See above ch. 3, p. 49.

${ }^{176}$ BDS 9.1:465, 1. 9-14, "...quae etiam in praesentia tanti Sacramentj magis efficacia et plus Valere censentur. Vt cnim Ciprianus inquit, in huius veracissimj et sancrissimj corporis praesentia non superuacue mendicant lachrime veniam nec Vnquam patitur contritj cordis holocaustum rcpulsam. Hic hierarcha pius eleuatione manuum crucis mysterium repraesentans conlidenter orat pro sua et populi ignorantia." See Ernaldus Bonaevallis Liber de cardinalibus operibus Christi 6 "De coena domini, et prima institutione consummantis onunia sacramenta" (PL 189:1647). Sec above, ch. 4 , p. 57.

${ }^{127}$ ACA 24 (BS 359). See above ch. 4, p. 58. 
inclusion of the word censentur: i.e. the sacrifices of praise at the Eucharist are reckoned more effective - though not by the Evangelicals.

\section{d The Fourth Sacrifice: Bread and Wine}

The fourth sacrifice was described as gifts of bread and wine. Part of this was consccrated and part became alms. Through these outward symbols and prayer the people showed that they dedicated themselves to God. The article cited the Decretales of Pope Fabian as witness, but noted that the practice had almost been abolished in the contemporary church. ${ }^{1.8}$

In his 1542 Apologia, Eck noted that the offering of various kinds of material gifts (e.g. bread, wine, wax, flour, cloth) still occurred "today" in Germany, Greece and France, and he mentioned (but did not specifically cite) a reference in Augustine to the practice of the African church. ${ }^{129} \mathrm{He}$ objected, however, that these "lay offerings" had nothing to do with the priestly offering in the Mass, "since thetc is only one outward sacrificc in the church, namely the Eucharist."1x. Eck's remarks suggest why recognition of a lay offertory was muted in mediacval commentary and Catholic apologetic: it seemed to blur the line of demarcation between the ministerial priesthood and the priesthood of the baptised.

As we have seen, Luther and Melanchthon had both identified a collection of food and alms as the original context of the offertory rite. Witzel's Typus had mentioned the people's oblationes, though it had not given them any prominence..$^{131}$ Without citing its sources, Bucer's Consilium theologicum notes that where the vocabulary of "offering" occurred in the Mass, the fathers and the decrecs it often referred to, "those offcrings which the faithful brought to the sacred Supper for the use of the poor." ${ }^{132}$ As we have already noted, the Leipzig article observed that

${ }^{128}$ BDS 9.1:465, 1. 15-21. According to BDS 9.1:465, n. 285, not in Ps.-Lisiore, Decretales, but see Crabbe 1:121 (Mansi 1:786D).

${ }^{179}$ Possibly "Augastine," Sermo spurizis 265 (PL 39:2238), in fact Caesarius of Arles, Sermo 13 (CCI. 103:65). Cf. BOL 3:24, n. 47 though included bere in Parkser's hand.

${ }^{130}$ Eck, Apologid N3b, "Quod submissa vatin solebant offerri in ecclesia, hoc hodie obsernatur in Gcrmania \& Graecia, vbi offeruntur panes, vina, cera, farina, panni, oua, sal \& panis omni dominico die, vt andio, benedicitur in Gallia, quem morem suo tempore in Aphrica testatur S. Augustinus: sed quid hae oblationes laicae, ad diuinissimam oblationem sacerdotalem in missa, cum vnum tantum sit sacrificium externum ecclesiae, scilicet Eucharistia?" Cf. Carranza's criticism of the four-sacrifices in Gropper's Antididagmat at 'Trent (CT 7.2:511) although Gropper's Enchiridion and Antididagma were cited favourably by Carranza elsewhere (ibid., 528,578 ) and by various other theologians (ibid., 6.2:527; 7.2:409).

31 Witzel, Typus 18a, "Alsdenn werden vom volck Oblationes geopffert, vnd das Offertorium wirt von Clero gesungen..." quoting Rabanus Maurus, De sacris ardimibus 19 "De missa" (PL 112:1178D); Fraenkel's fontnote to Bucer's Consilium (BOL 4:149, n. 7) refcrs us to "Witzcl, Typns, XIX et s." for the source of Bucer's interpretation of the oblationes of the minor Canon. Fraentrcl is using the Mainz 1540 edition, however, the above is the only reference to these oblationes in the 1541 edirion.

${ }^{132}$ BOL 4:149, "Pleraque etiam verba, quae de oblationibus sonant, de is oblationibus dicta 
mention of more than one kind of "offering" was found in the fathers. ${ }^{133}$ The Florilegium patristicum also contains a Latin translation of Justin Martyr's Apology 1.65 which mentions the presentation of bread before the eucharistic prayer and a collection of alms afterwards. Althongh this might seem an obvious source of information about the early eucharistic liturgy, Justin's Apology was not published until 1551 (Grcek; Latin translation in 1565). According to Fraenkel, Bucer may have mer with Johannes Lange, the translator at Regensburg and received a ms. version of the translation there. ${ }^{134}$ Even if this was the case, I have not found Justin cited elsewherc in Bucer's discussion of oflertory or almasgiving.

It should be noted, however, that the article did not refer to the collection of alms in general, but to bread and wine specifically. Moreover, although some of this offering was said to have been set aside as alms, the article suggested that its primary function was a liturgical one. The people's collection was referred to in the pasttensc: i.c. as a practice which used to happen in the ancient church. However, the article also rcferred in the present-tense to the "words" (sc, the minor Canon) with which the bread and wine are offered as symbols of the people's self-dedication to God: i.e. the content of the second and third sacrifices of the Mass. None of this is mentioned in Gropper's Enchiridion, though the idea is consistent with his understanding of the res oblata: i.e. both the historical and the mystical body of Christ under the consecrated species. It was not without precedent, either, in mediaeval commentary on the offertory. ${ }^{135}$

It appears, then, that Gropper sought recognition of the offertory prayers of the Roman rite specifically. Bucer, for his part, seems to have been ready to abandon the Strasbourg preachers' earlier rejection on these prayers, but with provisos. ${ }^{136}$ In the draft of the Worms-Regensburg Book sent to Philipp of Hesse, he had written that this part of the article was, "true if it were understood thus by everyone and those gifts of alms about which these words are to be understood were present." ${ }^{37}$ As we shall see, an offertory collection (without the prayers) would be restored in the 1543 Cologne order for the celebration of the Lord's Supper. Bucer would also bitterly criticise his adversaries' refusal to restore such a collection to the offertory of the Roman rite.

\footnotetext{
sunt, quae fideles in ecclesiam ad sacram caenam in usus pauperum conferebant."

ij BDS 9.1:30, 1. $15 \&$ p. 31, 1. 9-11. See above p. 134

${ }^{134}$ BOL 3:22-24, esp. 22, n. 38. Cf. PG 6:428f.

${ }^{35}$ See e.g. Durandus, Rationale 30.4.15, "Oblatio panis ot vini significat pia desideria fidelitum..." Also perhaps indirectly via the scholastic res tantum sacramenti, i.e. the unity of the mystical body of Christ. Sce, c.g. Lombard In Epistolam 1 ad Corintbios ad 11:23-24 (PT. 191:1642) \& Kilmartin, 120-122.

${ }^{136}$ See above ch. 5, p. 88; BDS 2:489.

137 BDS 9.1:465, 1. 22-23, "Verun, si ita ab omnibus intelligeretur et adessent illa elecmosynarum dona, de quibus Verba illa intelligenda sunt."
} 


\section{e The Roman Canon}

The final paragraph of the article discussed the Canon of the Mass and the attitude with which the laity were to approach its celebration. The Canon was said to contain "nothing unsuitable," as long as it was understood in the way which the article had already described. It deplored:

the superstitious opinion whereby certain persons, badly instructed about the naturc and encrgy of this most holy sacrament, used to think that they could draw off its power for themselves solely through the outward work which the priest performs, even if they brought to it no living faith, summoned no devotion, and offered their assent to the sacrifice by no formula of private or public prayer. ${ }^{138}$

It recommended that those who belicved that they could benefit from the priest's opus externum while persisting in public sin should be kept away from the sacrament. Those who persisted in secret $\sin$ in the same expectation were to be admonished to withdraw from the, "dreadful mysteries." ${ }^{139}$

These comments on the Canon are consistent with Bucer's claim in the Consilium that the superstition of the antichrist did not rcside in the "words" of the Mass. While the Florilegium patristicum contained material collccted from the Roman missal, Bucer would not discuss this material in print until after the colloquy Regensburg. Thus we shall postpone an analysis of his writing on the Canon until the following chapter.

It was widely recognised that some patristic commentators and liturgies referred to a disnissal of catechumens and penitents. Without citing any specific passages, Oecolampadius had alleged the expulsion of notorious transgressors and penitents, "in order that they might signify the mystical body of Christ more purely." ${ }^{140}$ Witzel's Typus cited the dismissal of catechumens, energumens and penitents it the liturgy described in De bierarchia ecclesiastica and in the Liturgy of

${ }^{138}$ Ibid., 467, 1. 1-7, "Iam si canon ille misse, quen veteres solemnem et prolixam precem super panem et calicem trifarie digestam appelauerunt, [Cf. I)ecretum Gratiani d.11, c.5 (Friedberg 1:24) citing "Augustine," i.e. Basil De spiritu sancto 27 (PG 32:188). Not noted ita BDS 9.1] In lunc quem diximus senstum intelligatur, nihil habet Jnconumodj. superstitiosa tantum absit opinio, qun quidam de natura et energia huilus sanctissimj sacrificij male edocti virtutem cius ex solo externo opere, quod facit sacerdos in se derinarj putabant, tametsi ilj tullam Viuam fidem adferrent, nullam pietatem adhibercnt, tulla ratione uel precum seu orationis sacrificio assensum praeberet..."

${ }^{1.19}$ Ybid., 1. 8-13, "...sc hic sacratissimae ac diuinissimae actionj damnabiliter miscuerunt, persuasi sibi missam solius externj operis, quod sacerdos facit, virtute prodesse, etsi ipsi nihil probac mentis adferrent. quae opinio damnanda est atque etiam tales, si publica sint crimina, a sacris arcendj, sin [sic] occulta, Vt se a tam tremendis mÿsterijs dum resipucrint subtrahant, clocendi sint."

${ }^{140}$ Oecolampadius, Ad Billibaldum Pyrkhaimerum, c4b, "Solcbant autem patres... non facile ad communionem admittere insignes facinosoros, licet pocnitente: quo purius designarent Christi corpus mysticum." 
John Chrysostom. ${ }^{141}$ However, it is likely that Bucer and Gropper understood article twenty's reference expulsion of public sinners and penitents rather differcntly. In Grund und Ursach an appeal to the practice of exclusion in the church "at the beginning" had been closely associatcd with polemic against the private-Mass as a subversion of the corporate dimension of the Eucharist. ${ }^{142}$ In fact this kind of exclusion was never enforced in Strasbourg. Instead, the unrepentant were merely admonished to absent themselves from the celebration and those who remained were exhorted to receive communion. ${ }^{1.43}$ It was clearly intended, however, that this kind of sacramental discipline would render the notion of a Eucharist without comnunicants unthinkable. Bucer may have hoped that the tightening of sacramental discipline in Catholic territories would have a similarly subversive effect. ${ }^{1+11}$

\subsubsection{Article Twenty-one: On the Administration of the Sacraments and Certain Specific Ceremonies.}

The twenty-first article of the Worms-Regensburg Book resembled the article which had emerged from the second Colloquy of Leipzig. The collocutors had not been able to agree on threc aspects of the celebration of the Mass, i.e. the Mass without communicants, the administration of communion under one kind, and the celebration of the Mass in Latin. As a consequence, their differing views were placed side by side. The article concluded that in these matters some middle path could be found by "erudite and godly men" through a diligent cxamination of the rites, formulas and observations which had been, "passed on by hand" and were characterised by their godliness. If it should by chance be discovered that something ungodly had crept into these traditions, it could be abolished and ancient purity restored. ${ }^{145}$ Here we are interested in the private Mass.

The Evangelical side of the question was put in terms of the institution of

${ }^{141}$ Witzel, Typus, 17a, 19 b.

${ }^{142}$ BDS 1:245. See also BIOS 2:463, "Auch ist by den altern vald noch den vmbsterclen der geschrifft des heren nachtmal nit ein speiß der schwachen, sunder fur die storcken ynd volkomenen, darzu die Neophyti vnd andere schwachen jm glauben ril gelassen würden." Though, as IJazlett, Development, 370 notes, Bucer would later emphasise, as Luther had done (BS 722, 1. 14) that the Eucharist was not sinnply for the "strong" and "perfect" but for the weals as well. See, e.g. Pollet Études 2:78.

${ }^{143}$ See e.g. the Vermalymung in the 1526-1536 Orders (Coena Domini 1:322-333). For the importance of this aspect of patristic sacramental discipline in the Reformed liturgies, see Old, 271282.

${ }^{144}$ See e.g. Abusum indicatio 5b, "Tollenda igitur erit tanta missarum multitudo nec ullis missae exhibendae, nisi qui digni sacrunentorum communicatione itudicari possunt. tum ad communicationem, quictunque sacris adsunt, diligenter inuitandi erunt. Nam haec sacramenta, non ad spectandtwn, sed ad sumendun instituta sunt. Hinc olim sub poena excommunicationis iubebantur communicare quicunque sacris interessent."

${ }^{145} \operatorname{BDS} 9.1: 473,1,3-10$. 
the sacrament. The instruction to take and cat would be overthrown if no-one but the pricst wcre said to communicate. It was also asserted that the ancient church followed this institution. Thus there should be no more private Masses ${ }^{1 \text { to }}$

The Catholics agreed that the people were to be encouraged to communicate as frequently as possible. This much is consistent with the Canons of the Council of Cologne. ${ }^{147}$ However, the Catholics defended the Mass writhout communicants, as long as there were present some who communed at least spiritually and "gave their assent" to the sacrifice. This, they wrote, did not contradict the practice of the ancient church, nor did it compromise the institution of Christ. The Mass was performed by the priest as a public minister of the church. 'Through it, he joined in faith with all those who shared in the sacrament the world over. The Catholics also expressed anxiety that the spiritual sloth of the present age would lead to the cessation of the "sacrifice of praise" if congregational communication were made the precondition of its celebration. ${ }^{148}$

Bucer's interest in the historical origins of the private Mass was already evident in the 1529 Epistola apologetica where he noted that none of the side-altars removed during the liturgical reforms in Strasbourg was found to have existed for more than two-hundred and twenty ycars. The private Mass was thus a recent invention. ${ }^{145}$ The texts collected under the heading "Private Mass" in the Florilegitm patristicum, suggest that, like Melanclithon, Bucer saw the origin of the private Mass in terms of the increasing frequency of communication on week-days and in "private" places: i.e. Monasteries and domestic oratories. He cited, for example, two letters from Jerome (also cited in Witzel's 1541 Typus) rcferring to daily communion in Rome. ${ }^{150} \mathrm{He}$ also cited Gregory's concession that Mass could be celebrated in a private oratory, providing that the founder of the oratory permitced it, "and a gathering of the faithful asked for it." "Privite Masses, in other words, were not originally celebrated in the parish and Cathedral churches, and even when they were celebrated in private places, they were celebrated for a monastic or lay community in which some used to communicate.

${ }^{146}$ Ibid., 1. 2-6.

${ }^{147}$ See above, ch. 7, p. 126.

${ }^{148}$ BDS 9.1:473, 1. 7- 18. According to the cditions of the Worms-Regensburg Book in CR 4:231 and ARC 6:82, 1. 25-29, at this point Gropper and Julius Pflug lad written in margin that this was their opinion, but that they would leave it to the Emperor and the Estates to decide how best this question might be selted for the churches on either side of the question. According to Augustijn and De Kroon (BDS 9.1:469, n. 287) however, this comment referred to the Catholic defence of communion under one kind.

${ }^{149}$ BOL 1:108.

${ }^{130}$ BOL 3:38; Jerome, Epistolke 48.15 8.77.6 (PL 22:506, 672); Cf. Witzel, Typus ecclesine prioris $16 \mathrm{~b}-\mathrm{nol}$ recognised by Fraendacl.

${ }^{151}$ BOL 3:38; Gregory Eptistolat 12.11 (PL 77:1226). 
The Consilizm showed little readiness to compromise on the private Mass. There was, Bucer wrote, no way of retrieving or using this ceremony in a godly way. Its very performance could only serve to strengthen the superstitions of Antichrist. He recognised, however, that there were some benefices which involved the celebration of such Masses. ${ }^{152}$ Those bound to such benefices must carefully weigh the scandal caused by desertion of their post against the scandal caused if they were to celebrate private Masses. Clergy who earned their living solely through the recitation of private-Masses were encouraged to find another position. The same advice was given to those whose benefice gave them no opportunity to give instruction in the proper use of the sacrament. ${ }^{153}$ Those not covered by these cases, having presented their perplexities to Christ in prayer, were encouraged to withdraw themselves from, "those private Masses and other superstitious ccremonies, as much as they possibly can." 154

On the other hand, in his 1534 memorandum to Guillaume du Bellay, Bucer had expressed his readiness to engage in disputation as to "whether, in some manner, it [i.c. the private Mass] could be a ceremony which had value in stirring up faith and thanksgiving." ${ }^{255} \mathrm{He}$ clained in the same place that Melanchthon was also willing to engage on a disputation on this subject. There is nothing to suggest this in the surviving abridged account of Melanchthon's memorandum, though, as we have seen, such a disputation is consistent with the proposals in his 1530 Indicium de missa. ${ }^{156}$

Does this mean that, in the interim, Bucer was prepared to allow the celebration of the public Mass without congregational communion as an absolute pre-condition? In De concilio et legitime indicandis controversiis (1545) Bucer strenuously denied Gropper's accusation to this effect. He would rather die, he wrote, than admit such a mutilation of the sacrament. An appeal to Christian liberty here was illegitimate. ${ }^{157}$ P'erhaps the clue to Bucer's alleged promises of discussions on this subject lies in the rider to the offer he added in the 1534 nemorandum: "just as there may be agreement on the principal questions of religion if we seek the Lord with sincerity, so it should be impossible for skirmishes

${ }^{152}$ BOL 4:59-60.

${ }^{153}$ Ibid., 56-57.

${ }^{154}$ Ibid., 60.

155 Pollet, Écudes 2:515.

${ }^{155}$ Ibid., 519. See above, ch. 7, p. 115.

${ }^{157}$ De concilio, $\mathrm{q} 4 \mathrm{a}-\mathrm{q} 4 \mathrm{~b}$, "... ausus est [1.e. Gropperus] scribere, me ipsi proposuisse, ut mediam aliquam uiam resituendae concordiac inter Protestantes, \& rcliquos Ordines Imperij, si liberum fieret Missas habere absque communicantibus, \& alteram tantum uel utramque speciem sacramenti distribuere \& sumere. Nam gratia Christo mori malim quam tantan sacramenti admittere deprauationem, $8 x$ mutilationem contra manifestum Scripturae testimonium." 
about this residual matter to endure." 158 It may be that what Gropper took to be an openness to further discussion on Bucer's part was an expression of confidence that once agreement had been reached on the nature of the Eucharist, the whole edifice of the private Mass and Mass without communicants would collapse of its own accord.

Bucer's intransigence, however, should toot lead us to overlook the concessions the Catholics had made both at Leipzig and at Worms and Regensburg. As we have already noted, Witzel, like Erasmus, agreed with the Reformers that the private Mass was an innovation. Eck's 1541 edition of the Enchiridion attacked "two who wish to be regarded as faithful to the holy Roman Church, and yet childishly attack the private Mass with empty-headed quibbling." It was on account of these "two," Fck wrote, that he had added a defence of the private Mass to his Encbiridion. ${ }^{159}$ Fraenkel identifics the objects of Eck's reproach as Witzel and Gropper. ${ }^{162}$ In fact Gropper had not mentioned the private Mass in his own Enchiridion (though that in itself may have been a sin of omission). However, a letter from Calvin to Farel claimed that at Regensburg the "adversaries" (unidentified) had offered to do away with the "marketing and multitude of Masses," to replace them with a single daily Mass in each church. This would not take place without a congregation, and the congregation would be exhorted to receive communion and instructed in the meaning of the sacrament. ${ }^{161}$ 'T'hus Bucer's collocitors sought to defend the public Mass without communicants rather than the private Mass proper: i.e. celebrated in a private oratory or at a side altar for a private istention.

Nor did they defend the Mass without communicants by appealing to its sacrificial character: i.e. on the basis that the priest could also apply the sacrifice to non-communicants. By way of contrast, the chapter on the private Mass in Eck's Encbiridion included a section pro applicatione in which the private Mass was defended with an appeal to the applicability of the sacrifices of the Old Testament. ${ }^{162}$ This might seem at first to be the intention behind Article Twentyone's claim that the priest "joins himself through faith" with all who, "participate

${ }^{158}$ Pollet, Études, 2:515.

${ }^{159}$ CCath 34:389, "...duo qui volunt haberi tanquam fidcles sanctac Romanae ecclesiae, et tamen missam privatam inanibus cavillis infantiliter impugnarunt." l'rivatc Mass also attacked in Beatus Rhenaauss 1540 "Praclatio in missa Chrysostomi," rcprinted in Flaccius Illyricus, Missa latina, quae olim anve Romanam circat 700 Domini annum in usa fuit... (Strasbourg: Christian Mylius, 1557), esp., 107. See also, Fraenliel, "Bcatus Rhenanus, historien de lia liturgie," Annitaire des Amis de la Bibliothèque butmaniste de Sétéstut (1985):247-252.

${ }^{160}$ CCath 34:389, n. 2.

161 CR 39:251.

${ }^{162}$ CCath 34:395-399. 
in the sacrament." 16.3 However, one of Gropper's sententiae at Trent suggests that his intention was to answer the objection that the Mass without communicants subverted communion. "The priest," he said, "even if he does not have present some who might communicate with him, communicates nonetheless with the church in all places, since we are one bread and one body who partake of the one bread." ${ }^{\text {tot }}$

By framing the discussion in terms of communion rather than application, the Catholics had sanctioned the elimination of the circumstances, envisaged in the Consilinm, which would force any priest to relinquish his benefice. They had stepped away from the "multiplication of Masses" toward a restored communal celebration of the Lord's Supper. As we have already noted, the sacramental discipline alluded to in Article Twenty could be hoped to take the Catholics a step further in this direction.

\subsection{Summary: 'The Mass in the Era of the Colloquies}

In the closing section of the Consilizum Bucer wrote:

whatever things the holy fathers once practised in a godly manner, we can also practise in a godly manner now - especially when it is not ours to change them: for the Lord has not wished to place it in our power to do so. ${ }^{165}$

Here Bucer admits two things which shed light on his approach to the Mass before and after the era of the colloquies. Firstly, he suggests that reform must take a different course when it docs not lie in one's power to institute change. Between 1524 and 1529, the Strasbourg preachers had been able to institute rapid and radical liturgical reforms with the support of the magistracy. Following the Diet of Augsburg, however, liturgical change in the remaining Catholic territories was less assured of success. The threat of military and legal reprisals hung over the heads of the Evangelical citics and princes, and over those who showed signs of wanting to join them. The Emperor's ability to implement these threats, however, was compromised by his need for financial and military support against the Turks. Perhaps, by means of a council of the German nation, or by a religious colloquy, the Empcror could be encouraged to contemplate a programme of moderate reform.

But what would the status of such a reform have been in Bucer's opinion? According to Francis Higman, a "scriptural" reform of the kind instituted in

${ }^{163}$ BDS 9.1:469, 1. 18-14.

$: 64$ CT 7.2:444, l. 7 .

$: 65$ BOL 4:166, "Quibusque olim sancti patres pie usi sunt, his etiam nunc pie uti possumus - praesertim, cum illit mutare non sit nostrum: Dominus enim id non in nostrin potestate poncre voluit." 
Strasbourg was always Bucer's ultimate goal. ${ }^{166}$ As Augustijn puts it in one of his earlier discussions, if complete reform in the Catholic territories was not possible, it might still be possible - by provisional and moderate reform - to make room for the preaching of the Gospel. Once faith in Christ and love of neighbour had been proclaimed, various minor abuses would disappear spontaneously. ${ }^{167}$ As Higman points out, the crucial phrase underpinning the programme of the Consiliztm was adbuc sub tyrannide papac. ${ }^{168}$

More recently, however, Augustijn has argued that the provisional arrangements were in fact those which Bucer had helped institute at Strasbourg. He claims that Bucer seized the opportunity offered by the colloquies (Regensburg in particular) to preserve a national German church, complete with existing structures such as episcopacy, while expunging "improper and inesscntial elements." As Per quos steterit (1539) and Abutsum indicatio (1541) suggest, Buccr regarded the Colloquy of Regensburg as an opportunity to reform the German church at a national level, and (as he had once done at Strasbourg) he argucd for the right and duty of the Christian magistrate (i.e. the Emperor) to initiate and implement such reform. ${ }^{169}$ However, it is one thing to say that Bucer might have felt able to live with traditional structures such as episcopacy. It seems to me quite another to imagine that he might have been prepared to live long with Articles Twenty and Twenty-one of the Worms-Regensburg Book. Indeed, Article Twenty-one, with its differing opinions laid side-by-side, was by its very nature provisional.

This provisionality seems to me the only explanation for a number of neuralgic points in the book's treatment of the Mass. Catholic insistence on the legitimacy of the Mass without communicants is an obvious example. The Book's apparent endorsement of Purgatory is another. The parties had been able to agree that the Mass was a sacrifice in four ways, but the phrase "present on the altar" seemed to bias any interpretation of the relationship between the four sacrifices in a Catholic direction.

On the other hand, the responses of Eck, Contarini and Sadoleto to the formulae indicate how much Witzel and Gropper may have appeared to concede to the Evangelical side. Insistence on the retention of daily Mass, regardless of the presence of communicants, did not amount to an endorsement of privatc Masscs. The fact that the practice was defended in terms of communion rather than application, may have represented a genuine advance as far as Bucer was concerned. Moreover, the Evangelicals had not bound themselves to accept this practice. It was

\footnotetext{
${ }^{166}$ Higman, "Bucer et les Nicodemites," 652

${ }^{167}$ Artgustijn, "L"Esprit d'Érasme," 382-383.

${ }^{168}$ Higman, 652.

I69 Augustijn, "Bucer's Ecclesiology," 113-114.
} 
to be discussed further. Purgatory was endorsed with Augustinian reserve by Gropper and Veltwyck and mentioned not at all in the Leipzig formula. Bucer does not seem to have regarded Purgatory as fundamentally objectionable anyway. What was objectionable was the association of Purgatory with indulgences and supererogatory works. None of the formulae mentioned these. Eck's objections to Gropper's phrase, "no less effective" suggests how novel Gropper's understanding of application appeared to be and why Bucer alleged that Gropper and Veltwyck were prepared to "drop" application. $\Lambda$ s long as the Mass was seen as four separate sacrifices rather than four aspects of the one sacrifice of Christ, then application appeared to Bucer to be no more than intercession offered by the priest on behalf of the church. Finally, Contarini's addition of the transubstantiatis clause to article fourteen, as well as Evangelical debate about the admissability of phrases such as transmutatio and even transconditionatio, give us some clues as to how Bucer might have been prepared to interpret the phrasc in altaris praesentia. This question is explored further in the following chapters.

It is clear that the articles of the Worms-Regensburg Book permit different interpretations. Are they then, a better illustration of Bucer's skills as a diplomat than as a theologian? I wonder whether this is in fact a legitimate distinction. If diplomacy means the art of legitimate compromise and pragmatism, then Bucer had a well developed theology of diplomacy. In 1537 he wrote to Thomas Cranmer distinguishing between "practical" theology and the rash "thcorctical" theology of Simon Grynaeus. The theoretical theologian, he wrote, had a conccption of the ideal church, but no idea or experience of what difliculties arose in the overthrow of Antichrist or in the establishment of the kingdom of Christ. He thought this an easy process in which no-one would wish to resist the kingdom of Christ or whit was founded on the Word of God and of profit to humanity. The pragmatic theologian, however, knew otherwise and practised patience. ${ }^{170}$

We have ample evidence of Bucer's growing recognition that reform, like the individual's growth in holiness, was something which happencd gradually rather than suddenly. From the time of Paul, the ministers of the Word had accommodated themselves to human weakness in order to draw some more fully to the truth. Whether or not Bucer believed that patristic eucharistic-sacrificial vocabulary had been such an accommodation, he clcarly believed that it had once been conducive to godliness. This much is evident in the Consilium's asscssment of the Roman rite. At Regensburg, agrcement on justification seemed to have becn secured and Melanchthon's bugbear, ex opere operato sine bono motw utentis had been

170 To Cranmer, 23.10.1537 (Epistolae Tigurinae de rebus ad ecclesiae Anglicanae Reformaizonem pertintentibus (London: Publications of the Parker Society, 1848), 342). 
explicitly rejected. Articles Twenty and Twenty-one could be regarded as the bcginning of a process of reversal by which, "whatever things the holy fathers once practiscd in a godly manner, we can also practise in a godly manner now." The aftermath of the Colloquy of Regensburg, however, suggests that the formulae of the colloquies were the beginning rather than the end of Bucer's reform progranme. 


\section{THE AFTERMATH OF THE FIRST COLLOQUY OF REGENSBURG (1541-1546)}

\subsection{Introduction}

At the end of the Diet which followed the Colloquy of Regensburg, Cardinal Contarini urged the German bishops to institute a "Christian reformation" by making provision for better pastors, preaching, education of the youth, and more modest living in their own households. ${ }^{1}$ At the same time Charles $\mathrm{V}$ signalled that he would allow the Protestant princes to act on their own interpretation of the agreed articles pending the decision of a general council. ${ }^{2}$ Bucer's Constans defensio (1543) and De vera et falsa catnue dominicae administratione (1546) have their origin in the attempt of Archbishop Hermann von Wied to introduce such a reformation to the ecclesiastical territory of Cologne. ${ }^{3}$ In Noyember 1541, Hermann invited Buccr to consult with him on the best mans of instituting this reformation. Bucer arrived at Buschhoven (one of the archiepiscopal residences) in February 1542. There he conferred with the archbishop and Gropper, before returning again to Strasbourg. ${ }^{4}$

In March 1542, Termann revealcd his plans to the Landtag and secured its assent. ${ }^{5}$ In September he presented the Cologne cathedral Chapter with a draft of his reform proposals. The Chaptcr abjected to the draft's Evangelical content and rejected it. ${ }^{6}$ The Archbishop then wrote to the Strasbourg Rat seeking to engage the help of Bucer and Hedio in the framing a new and more radical reform proposal. Bucer arrived in Bonn in December 1542, and was given a pulpit in the Minster thcre. At the same time he hegan a series of lectures (in Latin) on 1 Corinthians at the Franciscan Convent. As in the debate on the abolition of the Mass at Strasbourg, a lecture on 1 Corinthians allowed a speaker to deliver his views on the controversial subjects of Baptism and the Eucharist. ${ }^{7}$

Correspondence between Bucer and Gropper suggests that their relationship

\footnotetext{
${ }^{1}$ ARC $4: 5-7$.

${ }^{2}$ Ibid. 3:390-393, esp. 391. See also CR 4:623ff; CT 4:200f (Latin text).

${ }^{3}$ Stupperich 86a-b, 88; For the following discussion see: Köln, Martin Bucers Entwwy, esp. 44-46; De Kroon. "Bucer und die Kölner Reformation," in Martin Bucer and Sixteenth century Europe, ed Krieger, 493-506; Pollet, Martin Bucer: Études sur les relations de Bucer avec les Pays-Bas, l'Ëlectorat de Cologne, et l'Allomagne d"Nord, avec de nombretix textes inédils, (Leiden, 1985), 1:105ff.;

" Pollet, Martin Bucer 1:108.

${ }^{5}$ See Recess of the Landtag (ARC 4:218-219).

6 According to Köhnn, 41-43, this draft is lost and its author's identity unknown. Scc, however, AKC 4:221-225, no. 63 (Billicls's report on its contents).

${ }^{7}$ Pollet, Martin Bucer 1:116.
} T.enz 2:113-158. 
was still cordial and open to the possibility of further collaboration. ${ }^{8}$ According to Bucer at least, it was Gropper who had recommended him to the archbishop. Gropper strenuously denied this and claimed that Hermann's decision to invite Bucer to Bonn had taken him by surprise. ${ }^{9}$ He would soon throw in his lot with the opposition to the Hermann and his reforms.

This opposition centred on the cathedral Chapter and the University of Cologne. In February 1543 the Chapter published Sententia de vocatione Martini Buceri attacking Bucer's charactcr and the content of his preaching in Bonn. 'Ihe Chapter also claimed that the reforms proposed by the archbishop far exceeded anything sanctioned by the Interim. ${ }^{10}$ Bucer responded in March with Was in Namen der Heiligen Evangelii ietzund zu Bonn im Stifft Coellen gelebret unnd gepredigt würdt. ${ }^{11}$ In it he summarised the content of his preaching and defended his activity in the archdiocese. He called on his readers and opponents to judge whether or not his teaching was not consistent with Holy Scripture, the canons, the holy ancient councils and the holy fathers. ${ }^{12}$ 'These criteria were to shape the literary debate on both sides of the controversy over the next three years.

Bucer began work on a final draft of the reform ordinances in March 1543. In May, Melanchthon was invited to Bonn at Bucer's suggestion. Under the supervision of the archbishop and his advisors, the two men collaborated on the first edition of the ordinances, which was printed in August or early September $1543 .{ }^{13}$ At the archbishop's request, this German version, Von Gottes genaden wnser Hermans Ertzbiscboffs zu Cöln, unnd Churfürsten etc. Einfaltiges bedenken... was not circulated until September or October 1543 when a Latin translation, Nostra Hermanni ex gratia Dei Archiepiscopi Coloniensis Simplex ac pia deliberatio... had becn complcted. ${ }^{14}$

The Bedenken was divided into three sections: the first on Christian doctrine; the second on ceremonies; and a third on the reform of institutions such as the ministry. Wc know from Melanchthon that the doctrinal articles on the Trinity, creation, original sin, justification, the church and penance were principally his own work and that the articles on Baptism, the Lord's Supper, and

\footnotetext{
${ }^{8}$ Ibid, 106. See Gropper, Briefreechsel (CCath 32:240-242; 282-288). The last of these letters suggests that the relationship between Gropper and Bucer was degenerating by January 1543.

"Gropper, Warbaffige Antzeort, 5 la ff.

${ }^{10}$ BDS 11.1:434-446, esp. 439

${ }^{11}$ Tbid., 29-144.

${ }^{12}$ Ybid., 69; Sce also De concilio, n3b.

${ }^{13}$ Köhn, $67-68$.

${ }^{14}$ Stupperich, 74, 74a-c. For publication history, see Köhn, 60-63. Here I have used the text in BDS 11.1:163-429. According to Janse, Albert Hardenberg als theologe: Profil eines Butcer Scbülers, (Leiden, 1994), 19-20, 190, Bucer was assisted in the translation, by Albert Hardenberg
} 
church discipline were Bucer's. ${ }^{25}$ Neither, however, was given an entirely free reign. Hermann had instructed the pair to take Osiander's 1533 Brandenburg-Nuremberg ordinances as the basis for their work, and the influence of other contemporary church orders is evident as well. ${ }^{16}$ It is clear from the Bedenken's frequent references to "preachers" and the instruction of the people that the work was intended, like Gropper's Enchiridion, to serve as a catechetical hardbouk for the clcrgy.

The Beclenken had been printed, though not distributed when the Chapter published its reply: Cbristliche und calboliscbe Gegenbericbinting eyns erwirdigen Dhomkapittels zu Cöllen... ${ }^{17}$ On 4th November 1543, Melanchthon told Bucer that he had received copies of both works together. ${ }^{18}$ While the Gegenherichtung presented itself as a corporate production, it seems to have been primarily, perhaps solely, the work of Gropper. ${ }^{19}$ Gropper later claimed that he had composed the work in three weeks, since Hermann had given the Chapter only this long to reply to the Bedenken. ${ }^{22}$ The Cegenberichtung was written in German so that it could be read by the secular priests of the archdiocese. The Antididagna, a Latin translation by the Carmelite Provincial at Cologne, Eberhard Billick, was published in January 1544. It is to this translation that we will refer in the following discussion. Here was the Catholic response to Bucer's challenge to a disputation based on the fathers and canons of the pre-scholastic church.

The structure of the Antididagma was loosely modelled on that of the Bedenken. Certain non-controversial subjects were not addressed at all. For example, there was no section which corresponded to the Bedenken's chapter on the Trinity. Like the Bedenken, it begatn by identifying the sources of Christian doctrine: i.e. Scripture as interpreted by the church and unwritten "universal traditions." The sccond part addressed justification and related questions, the church and Christian prayer, the veneration of the saints, fasting and the use of images. The third part addressed the seven sacraments. 'I'he section on the Eucharist (eucharistic presence and sacrifice) occupied just undcr a third of the entire Antididagma. The defence of the sacrifice of the Mass alone amounted to approximately a fifth of the book (the discussion of justification, in comparison, occupicd about an eighth). Gropper and the Chapter clearly felt that the sacrifice of the Mass required a great deal of clarification. The Antididagma concluded with sections on disciplinary and administrative questions (e.g. feast and fast-days,

${ }^{15}$ CIR 5:113.

${ }^{16}$ Pollet, Martin Bucer, 1:156. Cf. Andreas Osiander, D. Ä Gesamt axsgabt, ed. G. Miiller \& G. Seebass (Gütersloh, 1983), 37-177.

${ }^{17}$ Lipgens, 226, no. 17.

${ }^{18}$ CR 5:220.

"See Gropper, Briefwechsel (CCath 32:332, n. 2); Pollet, P/tug 3:552.

${ }^{20}$ Gropper, Warbufftige Antwort, 67a-68a. 
celibacy of priests, reform of the schools and monasteries, care for the poor). Under each heading Gropper elucidated the Catholic position and then summarised the perceived deficiencies and errors in the Bedenken.

Bucer's reply appeared first in German as Bestendige Verantwortung, and was published early in 1545. A Latin translation, Constans defensio, was not published until 1613 , but it is to this that we will refer below. ${ }^{21}$ 'I'he structure of the Constans de/ensio lollowed that of the Antididagma almost exactly. In each chapter Bucer began by summarising his adversaries' objections, and then answered then. The discussion of the Eucharist mirrored that of the Antididagna in its relative proportions.

During his debate with the Chapter, Bucer was engaged in literary skirmishes with other Catholic apologists. De verd et falsa caenae dominicae administratione was the final product of an exchange of letters and pamphlets with Bartholomacus Latomus (c1490-1570). ${ }^{22}$ The relationship revealed in the literary exchange between Bucer and Latomus resembles that between Bucer and Gropper. Bucer seems at first to have thought that he had found one who shared his analysis of the predicament of the church and of the remedy to be applied to it. ${ }^{23}$ Indeed Latomus did deplore the state of the church with some vehemence. For him the abuses included not only the moral turpitude of the clergy and laity, but their ignorance of the Gospel, incomplete and contaminated doctrine and a collapse of the discipline found in the early church. ${ }^{24}$ Unlike Gropper, even in the thick of the debate, Latomus was ready to admit the limitations of his theological cxpertise and his readiness to be proven wrong by Bucer. ${ }^{25}$

However, when Bucer wrote to Latomus in June 1543, attempting to win his support for the Cologne reforms, Latomus wrote a Responsio expressing his disapproval. ${ }^{26}$ Latomus' Responsio addressed four specific topics: the administration of the Eucharist (i.e. under one or two kinds); the invocation of the saints; clerical celibacy; and the authority of the church. In his letter to Latomus, Bucer had urged

${ }^{21}$ According to t.p. and dedicatory epistle (Constans defensio $\$ 3$ b) talken from ms. by Bucer; but according to Janse, $19-20,500$, translation partially or fully by Hardenberg.

22 Stupperich, 88. See, Bietenholz 2:303-304; L. Keil, "Introduction," Bartbolomates Latomus (CCath 8:xi fif. Lattomus, a teacher of Latin rhetoric at the Collège Royal in Paris, had beer introduced to Bucer in 1539 by two lormer colleagues, Jean Sturnu and Johann Sleidan.

${ }^{23}$ Bucer, Scripta duo, 1.

${ }^{24}$ Latomus, Responsio (CCath 8:20-21).

${ }^{25}$ Latomus, Defensio (CCath 8:37) ${ }^{\circ}$ Errare possum, fateor, necyuc in hac contentione mihi quicquam aliorum prudentiam arrogo. Verum illud alss te peto, ne me condemncs prius, quan tuann quoque causam iudicari pormiseris. Ego doceri cupio, non a magistro tantum, sed etiam ab adversario..."

${ }^{26}$ Latonus, Responsio ad epistolam quandam Martini Bucceri [sic]... (Cologne: Novesianus, 1544). The exchange began as private correspondence, but Melchior Novesianus obtained copies of the letters and published then. 
him to prefer Scripture to all authorities in matters of religion. ${ }^{27}$ Latomus, however, expressed his disquiet with this method of proceeding. He accepted Scripture as, "dictated by the Spirit from the mouth of God." He noted, however, that even Scripture (2 Pet 3:12) recognised the obscurity of other passages of Scripture. The violence of the present religious controversy called for clear teaching. Who, he asked, would serve as interpreter where Scripture was obscurc ${ }^{28}$ Noting that Fisher and Luther, Luther and Oecolampadius, Eck and Bucer could artive at difforent interpretations of the same passages, Latomus plumped for the church as "pillar and mainstay of the truth." ${ }^{29}$

In March 1544, Bucer answered Latomus's Responsio privately. Later in the year, his letter (Responsio altera et solida) together with the entire correspondencc, was published at Strasbourg under the title, Scripta duo adverstria D. Bartbolomaei Latomi LL. doctoris et Martini Buceri theologi. ${ }^{30}$ In 1545 Latomus published a reply, the Defensio. ${ }^{31}$ In it he revisited the subjects he bad dealt with in his own Responsio, but in greater detail. So far, the sacrifice of the Mass had barely featured in the debate. However, a brief allusion to the subject in Latomus' Defensio seems to havc been the occasion of Bucer's lengthy treatment of eucharistic sacrifice in the second half of the work De vera et falsa caenae dominicae administratione published at Neuburg in April 1546.32

In his Responsio, Latomus had noted the discrcpancy between Bucer's interpretation of Malachi 1:11 and that of Eck. Here again, he argued, the church was needed to decide between the two intcrpretations. In Responsio altera, Bucer briefly defended his reading of Malachi 1:11, by referring Latomus to Irenaeus' Adversus baereses $4 .{ }^{33}$ It was because of the alms brought to the Supper in the early church, he argucd, and because of the invocation of God's name the confession and praise offered there that Irenacus regarded the Eucharist as the fulfilment of the prophecy of Malachi. It was not because the priests offered the Son to the Father in the Mass, as Eck and the other sophists alleged. ${ }^{34}$

\footnotetext{
${ }^{27}$ Bucer, Epistola prima (CCath 8:1).

${ }^{28}$ Latomus, Responsio (CCath 8:12).

${ }^{2 y}$ Ibid., 13. Cf. 1 Tim. 3:15.

${ }^{30}$ Stupperich, $78,78 \mathrm{a}$.

${ }^{31}$ Adversus Martinum Buccersm, de controversiis... altera plenaque defensio. (Cologne: Novesianus, 1545).

${ }^{32}$ Pollet, Études 2:14, n. 1.

${ }^{33}$ Scripta duo, 241. For the patristic passages in question, see discussion below.

${ }^{34}$ Ibid, 242-243, "Quia uero in sacra syrlaxi Eucharistiac hace Christianorum sacrificia omnia simul exhiberi debent, \& nominatim ex primo Apostolorum instituto fideles ad mensam Domini semper afferebant eleemosynas, qua distribuerentur intcr pauperes, de hac ipsa oblatione inuocationis, confessionis, laudis, eleemosynarum, quae ommia in sacra Synaxi offerebantur, ueteres plexique $8 x$ inter hos etiam Irenaeus uaticinium Malachiac oblatione Eucharistiae impleri scripserunt.
} 
In his Defensio, Latomus noted Bucer's insistence that, in the Eucharist, the church must do nothing but what the Lord had done. Here Bucer had appealed to Cyprian's Epistola 63. ${ }^{35}$ Latomus expressed amazement that Bucer should cite this father against him, when Cyprian referred in the same letter to the priest imitating Christ, the high priest, by offering what he saw Christ to have offered: i.e. sacrificium verum et plenum. ${ }^{36}$

It was this observation which seems to have stung Bucer, because he mentioned it in the preface to the second book of De vera et falsa. ${ }^{37}$ He wrote that. he had composed this work for Latomus and all those:

whose custom it is to pretend with a singular confidence, not to mention impudence, that where the sacrifice of the Masses is concerned, the authority of the holy fathers stands entirely for you against us. This is the false boast which, more than anything else, my sophist friends at Cologne have attempted to contrive. ${ }^{38}$

As this remark suggests, the sccond book of $D$ e vera et falsa was directed not only against Latomus, but against Gropper and his allies. The work contained some of the material which Bucer had already used in Constans defensio. However, it added further patristic citations and elaborated on a number of points in Constans defensio and Responsio altera. In both works we find Bucer using, for the first time, many of excerpts gathered it the Florilegium paristicum.

\subsection{The Principles Underlying the Debate}

Because of its importance of the fathers to both sides of debate, it is worth examining the way in which Bucer and his opponents articulated the relationship between the authorities (i.e. Scripture, 'Tradition, and the church) on which they based their arguments. The case which Bucer nakes here is particularly interesting

Quod autem Eccius \& Sophistae alij hunc locum co detorquere conantur, ut probcnt, Saccrdotem in Missa offerre patri filium..."

${ }^{35}$ Scriph duo, 42-43, though Bucer anticipates this criticism, 43, "Nce est quod cauilleris hoc loco de uerbo Offerre. \$. Martyr crim proposuit, de calicc Domino sanctificando $8 x$ plebi ministrando."

${ }^{36}$ Latomus, Defensio (CCath 8:46), "Quanquam illud mirum est, tanto studio te summi illits viri authoritatem miti opponere voluisse, nec vidisse interim locum illum non solum nihil facere contra me, sed obiter etiam incurrere in aliud dogma, vinum de calice dominico offerendo, in quo tu cum neges in dirino sacrificio panem et calicem pro peccatis nostris offerendum esse contra theologus nostros contraque vetustissimum ecclesiae consuctudinem... profuisset certe hoc telum non movisse..."

${ }^{37}$ De vera, 144. Book 1 deals with the church's right to modify the dominical institution of the sacraments, specifically communion sub wa.

38 Ibid., “...iactare singulari confidentia, ne dican impudentia soletis, S. Patrum anthoritatem, quod ad sacrificium Missarum uestranm attinet, stave ommino a nobis contra nos, Quam falsam gloriationem prae alijs adotnare conati sunt mei Coloniensi Sophistae" 
since he now turned the defence of unwritten tradition, developed against the Anabaptists in the early 1530 s, against his Catholic opponents.

The first section of the Bedenken located the source of Christian doctrine in Scripture, which it described as abundantly sufficient for the perfect knowledge of true and salutary doctrine. Here alone the Word of God was set forth in a way that was unmixed and ccrtain. ${ }^{3 n}$ Citing the well-rehearsed example of Augustine, it noted that the teachers of the church had requested that credence be given only to the parts of their work which were grounded in Scripture. ${ }^{10}$

The Antididagma countered with two commonplaces of Catholic apologetic: 1 Corinthians 11:2 (laudo vos, fratres, quod per omnia mei memores estis, et sicut tradidi vobis, praecepta mea tenetis) and 2 Thessalonians $2: 14$ (Lenete institutiones quas didicistis, siue per sermonem, siue per epistolam nostram). ${ }^{41}$ Both passages, widely recognised among the mediaeval canonists, were cited via Basil's De Spiritu sancto 27 (though usually attributed to "Augustine") where they had been used to support the contention that certain teachings of the church (in Basil the doxology in which the Spirit is glorified "with" the Father and the Son) had been passed on agrapbos (i.e. in unwritten form). ${ }^{42}$ Gropper seems to have had the whole passage before hin. He noted, that Basil had in mind the divinity of the Holy Spirit as a dogma founded on the church's lex orandi rather than the bare letter of Scripturc. He also noted that Basil described rejection of unwritten Tradition as injurious to the "principal parts" of the Gospel. ${ }^{43}$

Gropper, however, did not accord an undifferentiated authority to unwritten traditions. Here he used a number of passages from Augustine (principally Epistola 54 to Januarius, used by Bucer) to rank and distinguish between one invalid and three valid kinds of tradition ${ }^{4+}$ The first of the valid kind

${ }^{39}$ BDS $11.1: 170$.

${ }^{40}$ Tbid., 171. Cf. Decretum Gratiani 1 dist.9 c.3--5, 8, 10 (Friedberg 1:17) and Augustine, Epistola 82.1.3 (PI. 34:41); De baptismo contra Donatistas 2.3 (PL 43:128f); See alove, ch. 2, p. 15.

${ }^{41}$ Sec c..g. Fick, Encbiridion 13 (CCath 34:151), "...verbis Augrustini,"

${ }^{42}$ Antididagma, 1a citing Basil, De Spiritu sancto 27 \& 29 (PG 32:187, 199) attrib, in Decretum Gratiani 1 dist.11 c.5 (Friedber 1:23) to Augustine.

4) Antididlagma, 1a-b; Gropper (ibid. 1a-2a) also cites Ps.-Dionysius, De bierarcbia ecclesiastica 1.4 (PG 3:376); Irenneus, Adversus hatereses 3.4.1 (PG 7:855B); Chrysostom, Homilia 26 in 1 Fipisiolaw ad Corintbios (PG 61:213); Commentaritus in 2 Epistolatn ad Thessalonicenses 2.4.14 (PG 62:488); Epiphanius, Contra haereses "2.1" [i.e 3.1] (PG 42:516). Also with no specific ref.: Tertullian, De pratescrijutionibus (probably ch. 21 (PL 2:38) "... et hic praescribam non aliter probari debere, nisi per easdem Ecclesias, quas ipsi apostoli condiderunt, ipsi eis praedicando, tam viva, guod aiunt voce, quam per epistolas postea"); [Ps.]-Athanasins, Disputatio contra Arrium (prob. ch. 7 (PG 28:443C)); Origen, Peri archon (prob), ch. 3 (PG 11:116-117)).

${ }^{44}$ Antididatgma, 3a-4b; Cf. Artgtstine, Epistola 54 "ad Ianuarium" 1-5 (PI, 33:199-202); l's. Augustinc [i.c. Gcntnadius of Marseilles] Liber de ecclesiasticis dogmatibus 30-31. (PL 42:937) "Obsecrationem quoquc saccrdotalium sacranenta respiciamus, quae ab apostolis tradita in toto mundo, atque in omni catholica Foclesia uniformiter celebrantur, ut legem credendi, lex statuat supplicandi." 
was "universal" Tradition observed by the church throughout the world. According to Gropper, this was to be accorded the same authority as Scripture. Thus the Antididagma condemned the Bedenken for teaching that there was no certain revelation or tradition concerning the will of God or the salvation of humanity outside the writings of the prophets and the apostles; that the church was built solely on what is found expressly in Scripture; and that only this was be taught to the people. ${ }^{45}$ The second valid kind was "particular" tradition. This was observed only in parts of the church and was established to build up the faith and morals in response to specific circumstances in which the church has found itself. The Bedenken was condemned for having abrogated both universal traditions of the church and traditions particular to the archdiocese of Cologne. "The third valid kind was "superfluous" tradition. ${ }^{47}$ Such "traditions" were warranted neither by Scripture, councils of bishops, the custom of the universal church, nor other reasonable circumstances. 'T'o insist on them ran contrary to the Gospel. However, even where a beneficial purpose would be served by changing them, care had to be taken that this was not done in a way which disturbed public tranquillity. ${ }^{48} \mathrm{~A}$ fourth catcgory, invalid tradition, was that which was directly and openly contrary to sacred Scripture. It was not to be observed. No example was given."

Bucer responded that the adversaries had accurately summarised the teaching of the Bedenken. Outside the Old and New Testaments, there existed no book in which the sure teaching of God was handed down and revealed to us. 2 Timothy 3:[16-17] demonstrated that even the apostles did not hand on their teaching without the authority of Scripture, which, at that time, was the Old Testament. ${ }^{30}$ Bucer, however, had no difficulty in conceding to his opponents that the apostles had indeed handed on their teaching orally. Some of this was subsequently put into writing, (i.e. in the New Testament); some was not. However, one could discern from 2 Thessalonians 2:15 what the unwritten tradition was: "whatever nade it possible to promote both fuller progress in obedience to the Lord, as well as continuation and improvement in sanctification, in faith in the truth and

${ }^{45}$ Antididagma, 4b. C.. BDS $11.1170-172$.

${ }^{16}$ Antididagma, 6b.

${ }^{+7}$ Citing Epistola "19" (i.e. 55.19) "ad Ianuarium" (DI. 33:221).

${ }^{48}$ Citing Epistola 86.2 "ad Casulanum" (PL 33:136) (cl. Detretum Gratiani 1 dist.11 c.6-7 (Friedberg 1:25)) and De baptismo contra Donatistas "4.7" [4.5] (PI. 43:157).

${ }^{49}$ Antididagma, 2b-3a; Citing Augustine, De baptismo contra Donatistas 3.6 (PL 43:143); Cyprian Epistola 75.19 (CCL 3C:598) (Not in PI.) "Dominus cnim, non cgo sum consuetudo, sed ego, inquit, sum veritas."

${ }^{50}$ Constans defensio, 28. 
attainment of the glory of Christ." 51

The unwritten traditions discussed in the Bericbt and the Furbereytung had been disciplinary. In Constans defensio Bucer added a second category: doctrinal unwritten tradition. As examples of disciplinary tradition Bucer listed the following: the election, examination and ordination of minsters; baptism of infants; renunciation of the world, the devil, the confession of faith at baptism; the Apostles" Creed; confirmation of the baptised through the imposition of hands; the Lord's day; fasts; readings, prayers and offerings in the public celebrations of the church; support of the poor; the reception of communion before other foods. ${ }^{52}$ Examples of doctrinal tradition were the formation of the canon of Scripture, the doctrine of the Apostolic Fathers concerning the divine essence, the three persons in the Godhead, the incarnation of the Word and the two natures in the person of Christ. ${ }^{53}$

Returning to the sententia of Basil, Bucer sought to identify what unwritten apostolic traditions Basil had in mind. In addition to the liturgical confession of the Holy Spirit with the Father and the Son, he found mention of the sign of the cross, triple immersion in Baptism, the custom of standing to pray between Easter and Pentecost, and the "words of invocation" over the eucharistic elements. ${ }^{54}$ It was clear, he wrote, that even the adversarics did not observe triple immersion or standing after Easter. ${ }^{55}$ Thus he posited a further distinction between unwritten traditions which had wis ad pictatem and those which did not. There were, in other words, various "signs" which had come from the apostolic church but had no foundation in the Word of God nor any intrinsic capacity for promoting godliness. Some, such as the custom of giving milk and honey to the newly baptised had died out. Others had survived, but only with a great deal of superstition attached to them. ${ }^{56}$ In 1 Corinthians 14 the Spirit tanght that everything was to be done in a way which was understandable, decent and orderly for the building up of the body of Christ and for the promotion of godliness. Christus finis legis est, (Rom 10:4) and the tradition and teaching of the church had to have him as their goal and point of reference. Traditions of any kind should promote attentiveness to the dominical institution of the Sacrament, full comprehension of it, more fervent prayer for

51 Ibid., 29, "quam per quod promoueri potuerint, tum ad plenius obtemperandum Domino, tam ad pergendum, ac proficiendum in sanctificatione, in fide veritatis, \& acquisitione gloriae Christi." Cf. BDS 5:312.

${ }_{52}$ Constans defensio, 31,33 .

${ }^{53}$ Ibid., 33, 35. Cf. Florilegizm (BOL. 3:149-150).

${ }^{54}$ Cited but not quoted in Florilegitum (BOI. 3:142).

${ }_{55}^{55}$ Constans defensio, 40.

${ }^{56}$ Ibid., 40-41. Cites Tertullian De corona (PL, 2:98f) re, milk and honey for the newly baptised, the sign of the cross and fasting on Wednesdays and Fridays. 
Christ's help, thanksgiving for his benefits, and obedience to his commandments. As in the Furbereyinng, Bucer noted that the apostolic church and Jesus himself had permitted the abandonment even of practices with express scriptural warrant where these, "did not pertain to salvation of Christians at all times." Again the Sabbath observance and dietary laws were cited as examples, ${ }^{5 \circ}$ As we shall see, these distinction would be useful to Bucer in answering the claim of his adversaries that "offering" for the dead had scriptural warrant in 2 Maccabees 12.

Thus, Bucer did not have to rejcct any of the sententiae on unwritten traditions produced by Gropper. Not everything was received on the basis of Scripture, and this was all the fathers had been had claiming. ${ }^{59}$ However, all traditions had to be consonant with the Word of God. How, otherwise, was the validity of a tradition to be tested? Here Bucer cited 'Tertullian's De praescripitonibus: the truth of discipline or faith in Christ, of Scripture or of Tradition was one in the same. ${ }^{60}$ Whoever had the gift of the Holy Spirit could learn the true sense of Scripture easily, and would have no difficulty in discerning the proper relationship between Tradition and the Sacred Letters. ${ }^{61}$

Gropper had claimed that the gilt of interpretation resided in the church alone, and that teachers were given to the church to protect it against false doctrine. Here he citcd 2 Timothy 3:[14] and Bucer's locus classicus on the ministry: Ephesians $4:[11-13 .]^{62}$ Teaching authority in the church was identified with the legitimate succession of bishops and churches, and the truth handed on from previous generations. ${ }^{63}$ Gropper did not speculate on whether the consensus Ecclesiae or indeed the teaching ministry of the church had any historical or theoretical priority over Scripture.

Even though Bucer defined the catholic church as "all the faithful who have existed from the beginning of the world and have lived in every place right up to our age," ${ }^{64}$ he rejected the claim that the true understanding of Scripture was

Constans defensio, 31-32.

${ }^{58}$ Ibid, 32.

${ }^{59}$ Ibid., 42.

${ }_{60}$ Possibly De praescriprionibus 38 ([L 2:62), "Etenim quid contrarium nobis in nostris? Quid de proprio intulimus, ut aliquid contrarium ei quod esset in Scripturis deprehensum... Quod sumus, hoc sunt Scripturae ab initio sto; ex illis sumus."

6) Constans defensin, 43, "Quicunque donum habet Spiritus Sancti, is verum Scripturartum sensum facile ex ipsis Scripturis discere potest. Et qui spiritualis est, is adiumento Spiritus Sancti, \& S. Scripturarum nullo negotio inter doctrines traditas, ac verum S. Literarum intellectum, qui Ecclesiis ab Apostolis traditus est, discernere valet." See also ibid., 120.

${ }^{62}$ Antididagma 5a. See Van "t Spijker, The Ecclesiastical Offices in the Thought of Martin Bucer, transl. J Vriend \& L. Bierma (Leiden, 1996), 237-305; Flammann, 101.

${ }^{63}$ Citing Ps.-Clement, Epistola 1 ad Jacobum fratrum Domini (Crabbe 1:31-41).

64 Constans defensio, 48, "Catholica Frclesia... hoc est, apud omnes fideles, quatquot ab initio mundi fuerunt, \& quibuscunque in locis exstiterunt, \& adhuc sunt nostro seculo." 
automatically to be found in the catholic church or in any office. ${ }^{65}$ When the fathers had spoken about the apostolicity of a custom or a church, they had not meant that the truth was tied to certain persons or places (i.e. Rome or Constantinople). Rather, they meant that it should be sought where the gift of interpretation could be shown to have endured since the time of the apostles. ${ }^{66}$ Certainly, the catholic church was the "column and mainstay" of the truth, but only because it was built on the foundation of the Word of God and remained firm in the things found most surely in Scripture. ${ }^{67}$

He noted the objection that Scripture would not have been expounded in such different ways if its meaning was so clear. To this he offered two answers. Firstly, the true children of God who prayed for the gift of the Spirit perceived in Scripture all things necessary to salvation. These things had been handed on to the present church, satis et abunde... summoque consensu. ${ }^{68}$ Secondly, the Lord gave ministers to his church for instruction in sure and harmonious belief and knowlcdge of Christ. The medium and instrument through which these gave instruction was exposition of the Word contained openly in the Sacred Letters. ${ }^{69}$ In this way Bucer re-appropriated Ephesians 4:11 and 2 Timothy 3:14 from his opponents.

Regarding the dictum Augustini (i.e. "I should not have believed the Gospel...") Bucer admitted that the authority of the Holy Spirit had used the church's proclamation tamquam instrumento to move Augustine to faith in the Gospel. ${ }^{70}$ Teachers such as Ambrose had guided him toward the fullness of the truth, but the culmination of his journey came with the voice of the child: tolle, lege. In Contra epistolam Fundamenti 4 (the source of the dictum) Augustine had listed the things which kept hin in the catholic church: miracles; its consensus; the succession of its teachers. However (according to Bucer) he had claimed that the truth of Scripture was to be preferred to all these. He noted that Augustine's $D e$ doctrina christiana laid down the following requirements for sound scriptural interpretation: love of God and neighbour, the importance of understandixg the scriptural languages, the necessity of diligence and caution, and comparison of obscure passages with clearer ones. Nowhere did it mention that the truth was first

${ }^{65}$ Ibid., 47.

${ }^{6}$ Cf. Tertullian, De pratescriptionibus 32 (PI, 2:53-54).

${ }^{67}$ Ibid., 51, "Non negamus Ecclesiam cssc columnam \& firmamentum omnis veritatis. Quamobrem id vero? Certe non aliam ob causan, quam quod fundamento verbi Doi supcracdificata est, in his quae in 5 . Scriptura certissime reperiuntur, firma \& immota persistit."

${ }^{58}$ Ibid., 49.

${ }^{69}$ Ibid., 49, 51.

${ }^{70}$ Ibid., 54. Cf. BDS 2:100 whete Bucer rejected dicttm. Augustine should have said, "Ich glaubte der Kirchen nit, ja wisszt nit, das ein Kirch Cluristi were, ich glaubte, dann dem Evangelio..." 
to be sought in the catholic church. ${ }^{71}$

The Bedenken had enumerated three marks of the true church: truc doctrine; right administration of the sacraments; and "confession" of true doctrine. ${ }^{72}$ The Antididagma objected that true doctrine and its confession were the same thing. ${ }^{73}$ Bucer denied this. Among the people of Israel, true doctrine had been "rightly and legitimately administered" but had not been put into practice. Hence this assembly (coetus) of people had not been a church of God, but a Sodom and Gomorrah, a harlot and an adulteress. In the midst of the Jewish people, there might have existed many whom God preserved in the truc faith, but the question here was how to recognise the visible church, not the invisible church latens et sparsa. ${ }^{74}$ For Bucer, the visible church was recognised where individuals grew into communion with Christ and one another, where ministers and antistites (i,e. ministers exercising oversight) werc properly elected, and where the faithful were obedient to those in authority, and to church discipline. ${ }^{75}$

Herc Bucer remained open to the possibility, entertained in the Consilium theologicum, that true Christians were hidden and scattered within the papal church. However his insistence on a distinction between true doctrine and crue confession reveals his suspicion of the moderate reform from within proposed by Gropper and his ilk. ${ }^{70}$ Throughout the discussion of the Mass in Constans defensio Bucer protested that even where a legitimate complexion might be put upon the doctrine of the adversaries, their proposals did not bear fruit in practice. Rather their insistence on ancicnt practices and formulations served only to confirm ungodliness and superstition.

Thus Bucer concluded this section in Consians defensio by presenting the formula from the Commonitoriun of Vincent of Lerins (nsed on the first leaf of the

7: Constans defensio 54. Cf. Augustine, Confessiones 8.12 (PL 32:762); Contra epistolam Itondamenti 4 (PL 42:175). Augustine does not say what Bucer alleges here. Rather he claims that if the Manichaeans could show him the truth, then he would prefer it to all those things which keep him in the Catholic church (where the truth is contained) even though his tarditas intelligentiae has as yet pervented hirr from perceiving it apertissime. Bucer gives no specific references for De doctrina christiana (PL 34:15-122) perhaps because he summarises the content of the entire work.

${ }^{72}$ BDS 11.1:259-260.

${ }^{73}$ Antididagma, 27b-28a. Ibid., 27a, describes four marks of the church: sound doctrinc understood according to the universal catholic and apostolic tradition; proper and uniform use of the sacraments; the bond of unity and peace; the church's universal character. The latter two, says Gropper, are crucial for distingushing the church from hercsy.

${ }^{74}$ Constans defensio, 118.

${ }^{75}$ Constans defensio, $113-117$.

${ }^{76}$ See e.g. Epistola Prima (CCath 8:1), "Nec quicquam nos nomen ecclesine, nilil antiqui temporis vel amplissimi consensus authoritas ad tribunal Christi sublevavit, si non et privata confessione tum oris unn vitae totius ac publica et doctrina et ceremoniis omnibus, "praedicamus Dominum Iesum et hunc crucifixum' idque clarissime et confidentissime et ardentissimc." 
Florilegium patristicum) as a description of the church founded on the Word." It should be remembered, he wrote, that heresy and ungodliness had also been adhered to, ubique, omnibus temporibus et ab omnibus. However wherever there was true and effective fellowship in the full tcaching of the Gospel, in the sacraments, in confession, in discipline and in obedience to the commands of Christ, there the church was universal across all places, times and peoples. ${ }^{78}$ 


\section{EUCHARISTIC SACRIFICE IN CONSTANS DEFENSIO (1543) AND DE VERA ET FALSA CAENAE DOMINICAE ADMINISTRATIONE (1546)}

\subsection{Structure of the Argument and Some Preliminary Observations.}

As we have noted already, the structure of the argument in Constans defensio is largely determined by the structure of the argument in the Antididagma. The debate on the Mass falls into three major parts. The first is addressed to the question of whether the "Holy Supper" may properly be called a sacrifice. The second and longest part considers the "four sacrifices" of the Mass which had informed Article Twenty of the Worms-Regensburg Book and the discussion in the Antididagma. In Constans defensio at least, Bucer seems to have used the four sacrifice structure for the sake of argument. ${ }^{1}$ The third part of the discussion in Constans defensio offers a critique of the Roman Canon. Although Bucer would finally reject the Canon, this section suggests the grounds on which he might have admitred its continued use in less favourable ecclesiastical and political circumstances.

Because the second book of De vera et falsa identifies its "occasion" as a passing remark in Latomus's Defensio, Bucer was freer to structure the argument to suit himself. 'The Supper is discussed under the heading of five rather than four sacrifices. As we shall see, Bucer seems to have proposed this new model in order to avoid some of the ambiguities inherent in the Worms-Regensburg Book. However it is likely that the new structure was also designed to accommodate a development in his understanding of the Roman Canon. This discussion of the five sacrifices was followed by a lengthy treatment of prayer for the dead and the doctrine of Purgatory. The book closed with a defence of the reformed Cologne Order for the celebration of the Lord's Supper and provision for the burial of the dead.

\subsection{Catsa Offerendi: the Rationale of Sacrifice}

As we have noted, Gropper's Enchiridion did not identify what was sacrificial about the institution of the Eucharist. It simply observed that fathers such as Irenaeus had described it in these terms. The Antididagma, likewise, asserted that Christ:

not only distributed his flesh and blood to the apostles under the species of bread and wine, but at the same time he also offered a new

${ }^{1}$ See e.g. ibid., 308, "Tertium sacrificium Missac volunt Adversarij esse Christum Doninum nostrum, corpus $\&$ sanguinem eius..." [emph. mine]. 
sacrifice to God the heavenly Fathcr and instructed his apostles and their successors to do the same to the end of the world. ${ }^{2}$

In doing so Christ put an end to the ancient sacrifices, and instituted the sacrifice of the New Testament. This not only signified his bloody sacrifice on the cross, but contained its saving reality: i.e. his body and blood. ${ }^{3}$ Here, however, Gropper was not content with a bare appeal to typology. On its own, this kind of argument would not escape the Reformers' accusation that "allegories do not offer firm proofs." Rather, he attempted to identify a rationale for sacrifices in general.

The two typological sacrifices which Gropper produced in support of his case were the paschal lamb of Exodus 12, and the first-fruits offering of Deuteronomy 26. Unlike the paschal lamb, the first-fruits had not featured Catholic writing on eucharistic sacrifice in the 1520 s. Herc Gropper took his cue from Irenaeus's Adversus buereses 4.17. We noted above that Adversus baereses had attracted only passing and rather unreflective comment from Eck and Fabri.. In the debate between Gropper and Bucer, however, Irenaeus's remarks on the Eucharist were subject to closer scrutiny and shaped both men's views of the eucharistic sacrifice.

According to Gropper, the type of the Paschal Lamb was fulfilled in the words of institution which referred to the giving of Christ's body and the shedding of his blood for the remission of sins. ${ }^{5}$ However there was more to the typology than this. "l'he Eucharist, like the paschal lamb, and the first-fruits offering was instituted in "recollection, thanksgiving and praise" for the deeds of the Lord. This, Gropper argued, was in fact the function of all the libations and holocausts of the Old Testament. He noted the correspondence between "do this in memory of me," and Exodus 12:24 (cum introieritis in terram, quam dominus Deus claurus est uobis, ut pollicitus est, obseruabitis caeremonias istas religione perpetua). Likewise, in Deuteronomy 24, the priest offered the first-fruits, giving thanks to God for leading his people into the promised land and bestowing upon them all the things which he had promised.' Both sacrifices were instituted by God in order that both his

${ }^{2}$ Antididagma, 84b, "gon solum distribuisse apostolis suis sub panis \& uini speciebus carncm \& sanguinem suum, sed ctiam eodom tempore obtulisse Deo patri coelesti nouum sacrificium, \& apostolis ac successoribus eorum, ut id ipsum usque ad finem mundi facerent, mandasse."

'Ibid. 85a, "Christus... hic loco multiplicium oblationum \& sacrificiorum Veteris testamenti, quae tantum umbrae quaedam fuerunt rerum futurarum, nouum istud tradidit sacrificium. Quod certe sit manifestißimum, si uerba factaque Christi, uum uerbis \& ritu sacrificiorum Veteris testamenti conferantur." See also 86b-87a, ".. quod non solun significet, uerumetiam re ipsa in se contincat ueritatem illarum rerum..."

${ }^{4}$ Sce above, ch. 3, p. 35.

${ }^{5}$ Antitidiagma, 85a-85b.

${ }^{6}$ Ibiel. 
promises and their fulfilment might be recalled and enjoyed with thanksgiving and praise. Gropper noted that, after giving thanks for the first-Iruits, the sacrificcrs ate them. 'I'hus the entry into the promised land and the enjoyment of its riches were themsclves types of the heritage won by Christ.

Likewise in the Supper Christ had left his disciples an everlasting and unbloody memorial of the New Testament ratificd once and for all in his blood, so that they might enjoy a foretaste of its fullness:

He taught us to offer that most holy sacrifice to the heavenly Father, spiritually and in memory of him, again and again and forever, until he comes. This was not so as to merit afresh the remission of sins - as though Christ had not fully and sufficiently obtained these for believers once on the cross - but so as always to represent his passion and death and to set them forth before God the Father, mystically and figuratively, in memory of the redemption he won...; so as to give thanks to him that, because of his generous favour, he gave us and the whole world his only beloved Son, and through him remission of sins and all his gifts. As a consequence, through this spiritual representation, commemoration, thanksgiving, and chiefly through the reception of this most holy sacrament, we apply those divine gifts which he obtained and make them our own. ${ }^{8}$

Thus, although the Antididagma insisted that the Supper was intrinsically sacrificial, it insisted as well that the rationale of sacrifice was memorial (or perhaps better, realised memorial). By giving thanks for the gifts of God, bclicvers announced their faith in him. By this faith they "applied" the gifts of God to themselves (and others) not solely but chiefly in the reception of the body and blood of Christ.

In light of this emphasis on the primacy of communion and the memorial mature of the eucharistic sacrifice, it is perhaps not surprising that Buccr should have claimed at the beginning of the corresponding section of Constans defensio that the whole controversy rested on words, rather than the sense and understanding of those words. 'The principal test of the opponents' case lay not in the sense of their

${ }^{7}$ Ibid.

${ }^{8}$ Ibid., 87a, "Praecepitque ul sanctíßimum illud sacrificium patri coelesti iterum atque iterum ac semper, quousque ueniat, spiritualiter \& commenoratiue offeramus: non ad demerendarn eo primum remißionem peccatorum, quasi non sit per Cliristum semel in cruce omnibus credentibus plenaric \& sufficenter impetrata uerum in cius suae redemptionis memorian, hoc est, ut paß̧ionem eius \& mortem Deo patri.., semper niystice \& figuraliter representemus \& proponamus, agamusque propterea gratias eidem, quod nobis \& toti mundo dilectum unicum filinm sum, \& per cum remißionem peccatorum, omniaque sua dona, ex liberali gratia sua donauit, ut ita nobis istiusmodi spirituali reptaesentatione, commemoratione, \& gratintum actione, praecipue uero sumptione huius sandetißimi sui sacramenti, impetrata illa diuina dona applicemus, nobisque appropriemus."

${ }^{7}$ Constans defensio, 26 . 
words, but in their actual willingness to lcad the people toward a proper administration of the Lord's Supper - i.e. by excluding its usc as a source of worldly revenue and pomp, and conceding the need for changes to the liturgical status quo. ${ }^{10}$

This would be the burden of the Constans defensio, and, indeed, of De vera et falsai: "true teaching" must bear fruit in "true confession." The principal point of contention between the Reformers and their adversaries in Cologne was the latters' refusal to institute the kind of Reformation which Bucer believed should logically follow from the doctrinal casc which was articulated in the Antididagma.

Like the Antididagma, Constans defensio began by attempting to define the rationale of sacrifice in the Old Testament. Bucer listed the instances of sacrificial vocabulary in the New Testament: the sacrifice of Christ (I-Teb \& Eph 5:2); the preaching of the Gospel (Rom 15:16); the spiritual worship of Rom 12:1; sustenance for the ministry and alms for the poor (Philip 4:18 and Heb 13:16); confession of the name Christ (Heb 13:15). ${ }^{11}$ These sacrifices, wrote Bucer, possessed the same internal or spiritual character as those of the Old Testament. A marginal note in $D e$ vera et falsa remarked that under the New Testament only the species of sacrifice had changed, but not the res. ${ }^{12}$ Hence, the sacrifices of the Old Testament:

are no more than symbols and sacraments: firstly of our Lord Jesus Christ and of the redemption performed and acquired for us by his precious blood, together with the blessed communion in the divine and holy life of the Father which we have with him and through him as long as we live in him and he in us, and finally, of our faith and surrender of our whole will and obedience to God through Christ. ${ }^{13}$

Intrinsic to this obedience was the practical or ethical purpose of many of the typological sacrifices. Those sacrificed goods not consumed or used for some other spiritual signification were given for the support of the ministry or distributed to the poor. ${ }^{14}$

For both parties, then, "sacrifice" was an external observance instituted by God to remind those who believe in him of the fulfilment of his pronises and to stir in them the new life of faith. Gropper, however, insisted with the scholastics

${ }^{10}$ Ibid.

${ }^{11}$ Ibid., 267-268.

${ }^{12}$ De vera, 151 . Because some of the marginalia in this work seen to contain "last minute" partristic citations not included in the text, it is likely that the note is Bucer's.

${ }^{13}$ Ihid., 267. "... iuxta Scripturam veteris Testamenti sacrificia tribil aliud sint quam symbola \& sacramenta imprimis Domini nostri Iesu Chrisri, \& redemptionis factae \& acquisitne nobis pretioso sanguine eins vaa cum beata communione diuinae ac sanctae vitne, quam cum ipso \& per ipsum cum Patre habemus, siquidem in ipso viuimus, \& ille in nobis, denique etian fidei nostrae ac traditionis nostri in omnem voluntatem \& obedientiam Dei per Christum."

${ }^{14}$ Constans defensio, 267. 
that the sacraments of the New Testament contsined the grace which those of the Old merely signiffed. For Gropper, as we shall see, this implied the substantial conversion of the Eucharistic elements into Christ's body and blood. For Bucer the sacrifices of the Old and New 'l'estaments shared the same internal reality and the same "exhibitive" function when celebrated by the faithful. Here Bucer was heavily influenced by Augustine; Contra Faustum 20 in particular. We have already noted the use of passages from book 20.21 in the Consilium theologicum and the WormsRegensburg Book. The Florilegizm patristicum contains anothcr passage from 20.17:

In the sacrificial victims taken from the flocks, which the Hebrews offered to God in many and various ways, in a way befitting a matter of such great importance, they celebrated the prophecy of the coming sacrificial victim which Christ offered. For this reason Christians now celebrate the memorial of the same completed sacrifice in the most holy offering and sharing of the body and blood of Christ. ${ }^{15}$

At the end of the section on the sacrifice of the Mass in Constans defensio Bucer would describe this as one of his fundamental patristic texts. ${ }^{16}$

Despite a measure of agreement on the continuity between the Eucharist and the sacrifices of the Law, Bucer argued that it was preferable if the Eucharist were called by the names given it by the Holy Spirit (i.e. in Scripture). According to Bucer, these were, "the Lord's Supper," "the breaking of the bread," "the eating of the Lord's bread," "dispensing the cup of praise, drinking from the cup of the Lord and the communion of the Lord." The words "sacrifice" and "offering" could legitimately be applied to the Supper in so far as they charactcrised its celebration. However, he reiterated the argument, advanced by Melanchthon, that these terms could be applied to Baptism with equal legitimacy. ${ }^{17}$

Bucer also noted that there was no mention of sacrificc in De bierarchia ecclesiustica. Ps.-Dionysius called the Eucharist kowewvín and ovvo'sis. He also referred to the deirovpyia of the body and blood of Christ. Bucer noted that in his translation of Ps.-Dionysius' De divinis nominibus, Marsilio Ficino had used oblatio for deiтovpyía. He argued, however, that the Greek term was in fact a general one denoting no more than "sacred action." ${ }^{18}$ In this case the sacred action was the

${ }^{15} \mathrm{PI}$ 42:382-383, "Hebraei autem in victimis pecorum, quas offerebant Deo, multis et variis modis, sicut re tanta dignum erat, prophetiam celebrant futurae victimae quam Christus obtulit. Unde jam Christiani, peracti ejusden sacrificii memoriam celebrant, sacrosancta oblatione et participatione corporis er sanguinis Christi."; Constans defensio, 273-274.

${ }^{16}$ Ibid., 341. The others are Augustine, Enarratio in Psalmum 75; Cyprian, Epistola 63, and Chrysostom, Hornilia 17 in Hebraeos. For his use of the first two of these, see below, p. 199, 202.

${ }^{17}$ Ibid., 269.

${ }^{18}$ I.e. in Ficino, Dionysius Areopagitae praedarum opus de divinis nominibus Marsilio Ficino interprete, una cum ejus commentario (Venice, 1501). (CF BCor 1:14). Not located. 
proclamation of the Gospel which confected the sacrament. Bucer noted that in

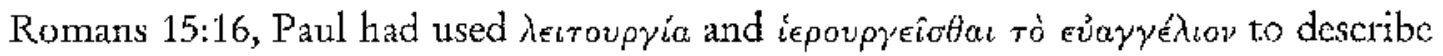
his own ministry of the Gospel. ${ }^{19}$ Here, as later on, Bucer conditionally accepted the apostolic provenance of De hierarchia ecclesiastica and De divinis nominibus on the basis that, even if the works were authentic, their eucharistic doctrine still bore more relation to the new Cologne order than the traditional Mass.

Bucer acknowledged that the fathers immediately after Dionysius (e.g. Irenaeus) did speak of the Supper as an offering and a sacrifice. However,

for the purposes of edification it is safest and most expedient to use the same names for the Holy Supper as those imposed on it by Scripture, especially in these times which are poorly suited to a true understanding of the sacrificial vocabulary, and in which many abuse it causing a disgraceful scandal. ${ }^{20}$

\subsection{The Four Sacrifices of the Mass}

As already noted, Antididagma and Constans defensio retained the four sacrifices structure which first appeared in the Worms-Regensburg Book (though in a slightly different order): (1) the offering of bread and wine; (2) the offering of thanksgiving and praise; (3) the offering of Christ; and (4) the church's offering of itself. In De vera et falsa, Bucer used a slightly different model. Ie listed five sacrifices: (1) the offering of Christ's Passion, also known as the offering of Christ or of his body and blood; (2) the offering of bread and wine "sanctified" for the use of the sacrament throtgh which the body and blood of Christ are "represented" to us; (3) the offering of thanksgiving and praise, i.e. the administration of the whole sacrament; (4) the offering of the "ourselves and of the whole faithful people;" (5) the offering of gifts which are brought forward by the faithful. ${ }^{21}$

Here Bucer also noted two nova genera oblationum in the "Greek Canon" (here the Liturgy of John Chrysostom): an offering of incense, and the fraction of the eucharistic bread into four pieces with a recitation of Isaiah 53:7. The latter

${ }^{19} \mathrm{Jbid}, 270,276$. Cf. Florileginm patristicum (BOL 3:21). Cf. Erasmus, Annotationes, 298 (on Rom 15:1), "biergounta, quasi rem sacram operans, ut respondeat ad leitotngon, qui proprie sacronnn minister est, \& bierourgein fungi administratione sacrorum. " See also De vera 165-166. Bucer (ibid., 164) cites "Gregory the Great" (i.e. Isidorc, Evymologiae 6.19 (PL 82:55, "Sacrificium dictum, quasi sacrum factum, quia prece mystica consacratur in memorian pro nobis dominicae passionis..." )) which he takes to be the exbibitio of the body and blood of Christ).

to Constans defensio, 269, "... tutissirnum est, \& ad acdificationem vtilissimum, eisdem nominibus S. Coenam appeliare, quae S. Scriptura illi imposuit, his praesertim temporibus, quibus de nominibus sacrificiorum ad verum intellectum non modo male contenit, sed etiam plerique ad horrendam offensionem iis abutuntur."

${ }^{21}$ De vera 147 , "Quile et quot genera oblationum \& sacrificiorum habuerit uetus Ecclesia." 
Bucer described as a "symbolic representation of the death of Christ." 22 As this suggests, the Liturgies of John Chrysostom and Basil were used extensively in De vera et falsa as keys to what Bucer believed had been the original sense of the Roman Canon. ${ }^{23}$

The principal difference between the four and five-sacrifice models was that in De vera et falsa, Bucer had separated the bread and wine "sanctified for the use of the sacrament" from the bread and wine collected from the people. He recognised, as we shall see, that some of the ancient eucharistic prayers included an "offering" of the sacramental elements which was in some sense distinct from the collection of the goods of the faithful.

\subsection{1 'the Offering of Bread and Wine}

In the Antididagma, Gropper acknowledged that the prayers of the minor Canon suggested that the Roman Eucharist had once included a collection of food and alms from which the sacramental elements were taken. Here he cited the Canons of the apostles (cited in the same context in Melanchthon's Apology), the Decretales of Fabian (citcd in the Worms-Regensburg Book) and the Secret of the fifth Sunday after Pentecost which referred to the "offerings of your men and womcn scrvants." 24

In Constans defensio and De vera et falsa Bucer cited these prayers with approval, and added examples of his own. All are excerpted in Florileginm palristicum. ${ }^{25}$ We cannot establish whether it was Gropper who prompted Bucer to use this material or vice versa. It is possible that the material was discussed during the secret colloquy at Worms.

Whatever the case, these praycrs confirmed for Bucer that where the minor Canon referred to "offering" and "sacrifice" it meant the offerings of bread and

${ }^{21}$ Ibid., 165. See Liturgy of John Chrysostom, Prothesis (Brightman, 356, 359)

${ }^{23}$ The Greek liturgies are not used extensively in Constans defensio, but there (328) he refers to two translations by "Johannes Tuscus" (i.e. Leo Tuscus/Toskanos (12th cent.)) and Ambrosius Pelargus. He asks his readers to compare them with the Greek text in "books printed at Venice and Rome." This strggests the collection of liturgical histories and texts whose annotations are edited in BOL 3:198-208. In De wert et falsd, Bucer is using the Latin parallel text in He theia leitourgid ton bagiou Loannou tou Chrusostomon... (Venice: per Ioannem Antonium, 1526) with slight corrections. For T'uscus ed. see Fraenlkel, "Beatus Rhenants," 249.

${ }^{24}$ Antididagma, 9cb. See above ch. 8, p. 156. See Missale Romanum, Secret for the Fifth Sunday after Pentecost, "Propitiare, Domine, supplicationibus nostris; et has oblationes famulorum famularum tuartum benigntss assume; ut, quod singuli obtulerunt ad honorem nominis tui, cunctis proficiat ad salutenz. Per Dominum."

${ }^{25}$ Constans defensia, 282, where he quotes the secret prayers for the fifth and seventh Sundays after Pentecost. Also quoted in De vera, 156 but as the fifth and seventh "after 'Trinity." See also in BOL 3:30-31 (fifth, sixth, seventh and ninth "after Trinity"). Antididagnat, 90b refers to the fifth and seventh after "Pentecost." Aquinas, ST 3a q.83 a.1 quotes from the ninth Sunday after Pentecost (Quoties huius hostiae commemoratio celebratur, opus nostrae redemptionis exercetur). 
wine brought to the Eucharist by the faithful. $\ln$ De vera et falsa. Bucer extended this clain to include the major Canon as well as the minor. He noted that the major Canon's prayers Te igitur, Memento Domine, Hanc igitur and Quam oblationem implied the presence of circumstanles, famuli et famulae, and the entire familia which made an offering of sacrificia and munera at the altar. ${ }^{26}$.

While Gropper admitted that oblationes in the minor Canon meant the collected bread, wine and gifts, he attempted to integrate this offering with the major Canon by speaking of a prior "mystical" or "significative" sacrifice by which the church showed its own self-offering through the symbols of bread and wine. It was not, he wrote, that the collccted gifts were thought to have any value in their own right; this was clear from Irenaeus's observation that God did not stand in need of them. Rather the priest and people offered;

so that in action and signs we may confess that the Lord God (who created all things and continues to keep all things in existence, who gives food to all flesh, who gives bread to bring strength to the human heart, and wine to bring it joy) so loved the world that he sent his only-begotten Son from heaven to earth for us. For he is the heavenly bread, the bread of angels and the true bread of life in whom God created all things, and in whom he has restored all that exists whether in heaven or on earth. For our sake the very same Son took on flesh, sacrificed himself, and poured out both blood and water from his side to cleanse us from our sins. ${ }^{27}$

Where the secret prayers of the seventh Sunday after Pentecost spoke of the offerings of bread and wine "helping us" and "working out our salvation," Gropper insisted that this did not mean that our salvation was furthered by bare bread and wine. Rather it nust mcan that, "the mysteries which we proclaim, which we signify by things of this kind, which we call to mind and apply to ourselves by faith, effect in us what we seek through divine power and through Christ our 3;31).

${ }^{26}$ De vera $156-162$. See sentertiate collected under Oblationes ad missam in Florilegizm (BOL

${ }^{27}$ Antididlagma, 90a-b, "...jn mysterio ad significationem ineffabilium beneficiorum Dei, sic uidelicet, ut rerun istarum oblatione significemus, ac opere \& signis confiteamur dominum Deum (qui omnia creauit, \& incessanter operatur omnia, qui dat escam omni carni, dat panem ad confortandum cor horninis, \& uinum ut cor hominis letificet) ita mundum dilexisse, ut unigenitum filium suum (in quo omnia creauit, in quo omnia quoque quae extant, siue in caelis, siue in terris reparauit, qui est panis coelestis, panis angelorum, uerus tuitae panis) propter nos miserit de coelis in terra. Idipsumque filium incarnatum pro nobis sese ipsum sacrificasse, aeque latere suo sanguinem 8 . aquam in ablutionem peccatorum nostorum effudisse." Cf. Irenaeus, Adversus baereses 4.18.4-5 (PG 7:1024-1025) “... hanc oblationem Ecclesia sola puram offert fabricatori offerens ei cum gratiarum actione ex creatura ejus..." Gropper also cites: Atgustine, De Spiritu et litera 11 (PL 44:211); Liturgy of Jahn Chrysostom, "Cherubic IHymn" (i.e. the Proskomide) (Brightman, 377-382, esp. 380, 1. 29m 381, 1. 10); 'l'heophylact Enarratio in Evangelizm Matthaei 26.26 (PL 123:443D). 
Lord." 28

Bucer did not contest this interpretation of the "significative" offering as such. He too, thought it legitimate to speak of the gifts helping us and working out our salvation. ${ }^{29}$ If "to offer bread and wine" meant,

to celebrate God on account of his many gifts, to tell of his kindnesses and show them forth, to call upon him for further blessing and grace, then it is certain that the Book of the Reformation [i.e. the Bedenken] does not overlook offering of this kind, but orders it to be observed and exercised." 30

In the Bedenken's Order for the Lord's Supper, the offertory of the Roman rite had been replaced with a collection. The significance of this collection and its location was explained as follows:

...each person who hears the Gospel with true faith, and recognises from it that out of his unfathomable love, God has given us his only Son and everything with him, will give himself completely to God and Christ, and make an offering of himself on account of this faith. Because of this, the faithful shall bring their free-will offerings while the Creed is being sung, each as a token of what has been bestowed upon him from the bounteous hand of God. ${ }^{31}$

This collection did tat include bread and wine for the Eucharist. However, in Constans defensio Bucer conceded that:

It would be proper, and in accordance with the custom of the Christian and primitive churches of God if the faithful were to bring along bread and drink with them for the poor and to offer these whenever they approached the Holy Supper. From these a certain

${ }^{28}$ Antididagma, 91a, "...mysteria praedicta, quae rebus istiusmodi significamus, \& in memoriam reducimus, fideque nobis applicamus, idipsum quod petimus uirtute diuina operentur, per Christum dominum nostrum."; Cf. Missalle Romanum, Secret for the ninth Sunday aftex Pentecost.

29 Constans defensio, 282 citing lrenaeus, Adversus hateres 4.17.5 (PG 7:1023). "Ecclesiam ideo hanc oblationem offerre, vt ipsi nec infructuosi nec ingrati simus, eique seruire discamus."

${ }^{30}$ Constans defensio, 283, "Si igitur offerre panem \& vinum est \& significat Deo pro talibus donis celebrare, ac beneficia eins enumerare $\&$ predicare, eum pro vilteriori benedictione \& gratia inuocate, certe Liber Reformationis huiusmodi oblationem non praetermisit, sed obseruandam \& exercendum ordinauit."

${ }^{31}$ BDS 11.1:348, "Vnd dwejl [sic] ein jeder, der das H. Fuangelium mit waren glauben gehoext, und auß dem erkennet, das jm Gott auß seiner grundtlosen liebe, seinen Son, vnd nit dem alles geschenckt hatt, auch auß solichem glauben sich selb Got, vnd vnserem Herren Christo gantz ergibt, vnd auffopfferet, also sollen die gleubigen die weyl man den glaubon singet, jre frey willige opffer bringen, ein jeder nach dem segen der jon von der milten hand Gottes verlehnet ist." Sce also ibid., 285-289 on "Christian offering" both in the contezt of the Supper and outside it. 
portion would be consecrated and distributed in the same way as it used to be done by the ancients... ${ }^{32}$

Here Bucer cited Cyprian's De eleemosyna 15 (also excerpted in the Florilegium) in which a wealthy woman was reproached for having contributed no bread and wine to the communal collection for the poor, but having "eaten the part of the sacrifice which the poor man offercd" (i.e. the bread which he had contributed for the celebration of the Eucharist). ${ }^{33}$

However, although Bucer conceded that thanksgiving was essential in the Supper, he argued that the physical offering and dedication of gifts was not. The "offering" of bread and winc must be considered, "an offering different and separate from the thanksgiving, prayer and memorial of Christ and his passion which follow." Tertullian, he claimed, had spoken of the "offerings" of the faithful in a way that distinguished them from, the "bread and wine of the Lord." "The essence of the offertory lay finally not in any particular symbolic act, but in the accompanying prayer. ${ }^{36}$ It was thus that the observance of the ancients had becn preserved in the Bedenken.

Bucer also pointed out that the obscrvance of the adversaries squared with that of the fathers even less than that of the Bedenken. He seized on their apparent admission that a collection of bread, wine and almus was something which might properly be restored in the contemporary Roman rite. All the thetoric, the "paint," which the adversaries had used would not stick to the wall they were trying to redccorate. They tried to shelter under the cover of the "fathers" but would not follow their example. ${ }^{37}$ The offering for the poor was turned into an offering of

32 Constans defensio, 281, "Decorum quiden esset, Christianarum \& primitiunum Ecclesiarum Dei consuetudini consentaneum, si fideles, quoties ad S. Coenam accedint, panem ac potum pro pauperibus secumque adducerent \& offerent Domino: ex quibus portio quaedam consecraretur, \& distribueretur, quemadmodum ab antiquis fieri solebat..."

${ }^{33}$ Ibid., 272; (if. De vera, 153; Ilorileginm (BOL 3:30); Cyprian, De opere et eleemosynis (PL 4:636m637). He also quotes Paulinus of Nola, De gazophylacio (PL 61:345), "Non patiamur ergo mensam Domini, et nobis vactaam, et egentibus inarem, relinqui..."

${ }^{34}$ Constans defensio, 284, "Haec sanc tealis oblatio erat per se: non quidem sine Christo, fideque propria, \& traditione in voluntatem \& obedientiam Christi: adhuc considerata in se ipsa alia erat oblatio \& diuersa a sequenti gratiarum actione, oratione, ac memoria Christi \& passionis eius."

${ }^{35}$ Ibid., 271. No specific passages cited here.

36" Ibid., "...Ecclesia non ad panem \& vinum per se respicit, sed potius ad adiunctam confessionem, gratiarum actionem \& orationem, item ad Christum Dominum ipsum \& passionem cius, vna cum oblatione ac deditione in obedientiam illus."

${ }^{37}$ Ibid., 283, "Et quidem elegans hic color csset siquidem \& parietem cui colorem istum inducere conantur, recipere vellent. At quis, obsecro Missatorum de tali confessione vnquam cogitat, vel populum instituit... Quare color eorum non haerer, sunque nihil aliud quam inania verba \&. nugae, quacque dicunt, quibus horrendos abusus suos in hae actione fucare conantur. Perpetuo tentatn verbis \& actionibus S. Tatrum se tegere, reipsa autem res imitari nolunt." 
candles and money for the priests. ${ }^{34}$ The priest said the offertory prayers not over bread, wine and alms collected from the congregation, but with a "morsel of bread and a few little drops of wine." Discussing the Canon's references to the adstantes and their offerings he asked:

where now are the "mon-servants and women-servants who offer this sacrifice of praise?".. Where now the "entire family?"... So you see clearly that at the time this Canon of yours was composed and used by those who understood it, the "gifts," "sacrifices" and "offering" of which it spoke were a good deal more than this paltry piece of bread and drop of wine..."

'The meaning of Gropper's "significative" sacrifice, he wrote, was never explained to the people, and he doubted that it was understood by many of the priests either. Indeed their very ungodliness indicated that it was entirely misunderstood. ${ }^{41}$

For all this, it is not clear (in Constans defensio at least) how Bucer understood the passnges from Adversus baereses which underlay the debate at this point. Like the Antididagma, both Constans defensio and De vera et falsa made much of Irenaeus' Adversus bacreses $4.17-18$ as the earliest "more certain" witness (i.e. more certain than Ps.-Dionysius) to the ancient celebration of the Lord's Supper. Bucer listed four reasons why Irenaeus supported the Evangelical case. Firstly, the material "offering" in the celebration of the Supper was, "nothing more than bread and wine with the giving of thanks; and not a word suggests the offering of the body and blood of Christ." ${ }^{2 z}$ Secondly, Irenaeus cautioned that, "we, do not offer these gifts to God as if he stood in need of them." Thirdly, Irenaeus wrote that,

${ }^{38}$ Ibid., 282, "... quod maius est oblationem fidelium, quae pecunia \& candelis fit, pauperibus omnino subtraxerunt"; ibid. 284

37 Ibid., 282, "Verum oblationem istam panis \& vini veteribus mysterium fuisse, cui congruat id quod nostro tempore Dinconi site sacerdotes pauxillum panis, \& pauculas guttas vini ir calice conficiunt, id longe aliter se habet."

${ }^{40}$ De vera 157-158, "Vbi ntunc hi famuli \& famulac, qui hoc sacrificium laudis oflcrunt?... Vbi nunc cuncta familia?... Cernis itaque clare, \& eo tenpore quo Canon ille uester compositus, \& intelligenter usurpatus est, munera, \& sacrificia, atque oblationem de quibus loquitur, haud quaquan fuisse ptsillum illum panem, \& pauxillum uini..." He notes ibid., 157, that pro quibus tibi offerimus could not be found in the earliest versions of the Canon which he had examined. Sce Canon missae, Metnento Dumine.

${ }^{41}$ Constans defensio, 282, "Impia quoque est, \& irreligiosa socordia, imo peruersitas, dicta consuetudine ad mensan Domini offerendi praetermissa, penitusque collapsa, vetertum oration's ac verba, quate super memoratas oblationes pronunciarunt, tanta pompa ac ceremoniis in qualibet $S$. Coena recitare, vtque recitentur serio exigere: cum tament eiusmodi oblationes non adsint: eamque ob causam talium precationum verba nemo recte, plerique vero deprauatissime \&z maxime scandalose intelligant."

${ }^{42}$ Ibid,, 270, "... testatur Ecclcsiam ab $\Lambda$ postolis accepisse, vt in S. Coena nihil aliud quam panem \& virum offerret cum gratiarum actione; oblationis vero corporis \& sanguinis Christi ne verbo quidem meminit." Cf. De vera, 154; Irenaeus, Adversus baereses 4.17.5 (PG 7:1023). 
"sacrifices do not sanctify a man but that the pure conscience of the one who sacrifices sanctifies the sacrifice. ${ }^{343}$ Fourthly, because the sacrifice in question was the sacrifice of the church, it could not, Bucer concluded, be the sacrifice of Jesus himself. Rather, it was the pure, sweet-smelling and acceptable sacrifice of Malachi 1:11, Romans 12:1, Philippians 4:18. ${ }^{44}$ Yet, in all this he had avoided answering Irenaeus's claim that Christ had instituted the Eucharist precisely as an offering of the created elements of bread and wine: "the new offering of the New Testament." Offertory in other words lay at the heart of the institution of the Lord's Supper; it was not an optional adjunct. In De vera et falsa Bucer himself would re-visit this problem when discussing the offering of the sanctified bread and wine.

\subsubsection{The Offering of Christ}

The Antididagma treated the offering of bread and wine in the minor Canon as part of a liturgical wholc in which the self-offering of the church (symbolised by the elements) became united sacramentally with Christ's offering of his own body and blood. Bucer argucd that his opponents could not have it both ways. They could not speak of four sacrifices and then attempt to link them together into one. ${ }^{45}$ Here Bucer highlights what I believe is an important difference between himself and his adversaries. In order to clarify this point, I propose a temporary departure from the sequence followed by Bucer and his opponents. This will involve skipping ahead to the "offering of Christ" and discussing its meaning for the two sides in light of their differences regarding the nature of Christ's presence in the Eucharist. We will then return to the "application" of Christ's sacrifice. Bucer and his opponents considered this under the heading of the sacrifices of thanksgiving and praise of the church.

Catholic anxieties about ambiguities concealed in the Worms-Regensburg Book had led Contarini to insist on an unambiguous assertion of transubstantiation. The same desire to avoid ambiguity was evident in the Antididagma. ${ }^{46}$ Firstly, Gropper insisted on the necessity of a prayer such as the

${ }^{13}$ Constans defensio, 271, "Idem Pater... indicauit, non sacrificia sanctificare hominem, sed conscientian purann eius qui olfert sanctificare sacrificium...In hoc testimonio D. Irenaei illud quoque diligenter animaduertendum est, quod de causa oblationis scribit: nempe quod Dominus in veteri \& nouo Testamento docuerit offerre, non, wh aliquid Deo indigenti demus aut promereamur ab ipso..." Cf. De vera, 151-2; Irenaeus, Adversus baereses 4.18.3 (PG 7:1025).

${ }^{44}$ Constans defentsio, 271.

*j Ibicl., 283, "Ad extremun notel Christianus Lector circa hunc locum $\Lambda$ duersarios quo pani \& vino suo fuco quodam patrocinentur, ad ca adiungcre Oblationem Christi Domini \& passionis eius, item fidelium mentiurn, oblationem videlicct Ecclcsiac \& communionis Christi, hoc est omnes tres residuas oblationes, quas missae attribuunt. Ad quid hoc aliud est, quam id quod antea affirmare, rursus negare: posuerunt enim panem \&x vinum esse peculiarem oblationcrn a reliquis sepuratam."

15. Antidildagnd, 64b-66a. 
Canon for the valid consecration of the Eucharist. The minister of the church blessed and sanctified the eucharistic with the almighty words of the Christ. However, Gropper emphasised that the consccration was not a recitation of an historical account such as that found in 1 Corinthians 11. One who attempted to confect the sacrament by reciting no more than these words:

does not, as a minister of the church, call the name of God upon the presented gifts of bread and wine, nor does he direct the words of consecration to the host before him, [italics mine] and in no way does he consecrate or effect the true sacrament in accordance with the agreement and tradition of the catholic church. ${ }^{\text {it }}$

We will return to this passage when we consider the role of the church's minister in the eucharistic sacrifice. For the moment, however, I want to concentrate on the consecration. According to the Antididagma, the consecratory formula effected a change in the bread and wine. As evidence of this, Gropper listed patristic sententiae (beginning with Dionysius) which referred to an invocation or prex mystica by which the elements were transformed into the body and blood of Christ. ${ }^{48} \mathrm{He}$ also appealed to the epiclesis in the Liturgy of Jolnn Chrysostom:

The bishop rises and makes a sign (doubtless that of the cross) over the offering and says, "O Lord make this bread your precious body, Amen." And over the chalice he says, "Make what is in the chalice the precious blood of your Christ, changing it by the power of your Spirit."

Such prayers, claimed Gropper, witnessed to the belief of that, "the bread is

${ }^{47}$ Ibid., 112b, “... non inuocet autem tanquam Ecclesiae minister, nomen Dei super dona proposita panis \& uini, nec item consecrationis uerba dirigat ad hostiam praesentem, hunc talem nequaquam consecrare, nec uerum sacramentum secundum Ecclesiae Catholicae sensum \& traditionem efficere"

${ }^{+3}$ Antididagma 112b-113b. Cites Ps.-Dionysius De bierarcbia ecclesiastica 3.3 (PG 3:442) (ref. to soleman words proceeding consecration); Irenaeus, Adversts baereses 4.18.5 (PG 7:1028) (See discussion re epiklesis below, p. 194) Ps.-Cyprian, De coena Domini (PL 189:1642D); Basil, De Spiritu Sancto 27 (PG 32:186-196); Theoplaylact, Enarrationes in Evangelium Marci (PG 123:649); Chrysostom, De sacerdotio 3.4 (PG 48:642) (see Lepin, 56-57); Ambrose, De sacramentis 4.4 (PL 16:439) (via Decretum Gratiani 3 de consecr. dist.2, c.55 (Friedberg 1:1334)); Ambrose, "De officiss" i.e De mysteriis 9 (PL 16:426) (via Decretum Gratiani 3 de consecr. dist.2 c.40 (Friedberg 1:1328)); Avgustine, Contra Faustzm "13" [20.13] (PL 42:379); De Trinitate "4" [3.4] (PL 42:873-874) (see Decretum Gratiani 3 de consecr. dist.2 c.60 (Friedberg 1:1337)); Gregory, Epistola 63 (PL 77:956958).

49 Antididagma, 113a, "Missa Graeconum prodit, quod Episcopus sc erigat signctque; (proculdubio crucis signo) oblationen, \& dicat: Fac, o domine hunc panem praeciosum corpus Christi tui, Amen. Et in calicem dicat: Quod in calice est, fac praetiosum sanguinem Christi tui transmutans spiritu tuo sancto." (Brightman, 387). Cf. BOL 3:201. 
not only a figure and example of the Lord's body, but is 'transelemented' into it." Gropper identificd the Quam oblationem, (i.c. the prayer immediately preceding the consecration in the Roman Canon) as the counterpart of the epiclesis in the Anaphora of John Chrysostom and Basil. The antiquity of the Quam oblationem was demonstrated with an appeal to Ambrose's De sacramentis $4.5 .^{51}$

In Constans defensio Bucer confirmed Gropper's suspicions by asserting that, "whatever prayers are uttered over the bread and cup are uttered for our sake, so that through these sacraments we might receive Christ to our salvation." This, he claimed, was the way itl which Aquinas and the other scholastics understood the consecratory effect of the words of Christ. ${ }^{52}$ T'aking several of Gropper's references to invocatio Dei or prex mystica, Bucer argued that most of them referred to the words of Christ, rather than an "invocation" such as the Quam oblationem."

Bucer was nevertheless ready to admit the language of "change" or "conversion" if it meant that the eucharistic elements were transferred from ordinary into sacramental use. ${ }^{54}$ Thus, with no prompting from Groppcr, he cited the sententia of "Eusebius Emisenus" (i.e. Faustus of Riez) which referred to Christ as the invisible priest "converting" the visible creatures of bread and wine into the substance of his body and blood by his word. ${ }^{55}$ He also drew attention to the christological implications of his doctrine of the real presence by quoting from Pope Gelasius I, De duabus in Christo naturis contra Eutychen et Nestorium:

The sacraments of the body and blood of Christ which we consume, are a divine thing, and on this account and through them we are made partakers in the divine nature [2 Pet 1:4], and yet the substance or nature of the bread and wine does not cease to exist...just as they pass over into this, the divine substance, through the opcration of the $\mathrm{Holy}$ Spirit, and yet the property of their nature remains, so, by remaining in the proper sense those things which they are, they demonstrate that

${ }^{50}$ Antididagma, 113a, "Non enim Eiguram tantum $8 x$ exemplar dominici corporis panem esse, scd in illum transelementari"

${ }^{51}$ Antididagma, 113a. Cf. Liturgy of John Chrysostom (Brightman, 386-387); Ambrose, De sacromentis 4. 5. (PL 16:462). Again the attribution of this work and passage to Ambrose is contested, Constans defensio 204.

${ }^{52}$ Constans defensio, 324: "Quaecunque igitur preces super pane \& calice funduntur propter nos funduntur, nempe ut per haec sacramenta Christum ad salutem nostram percipiamus... Thomas enim \& alij omnes fatentur, Sacerdotem quando verba Christi super symbola recitat, intentione ea consecrandi, vere sacramentum conficere." Cf. Aquinas, ST 3a q.78 ‥1.

${ }^{53}$ Constans defensio, 320-323. Also cites Ambrose, De mysteriis 9 (via Decretum Gratiani de consecr. dist.2, c.85 (Friedberg 1:1349)), "... non ergo corporalis esca sed spiritualis."

${ }^{54}$ Constans defensio, 200.

55 Ibid., 323, Emisenus, "hanc veritatem clare exprimit." See Decretum Gratiani 3 de consccr. dist.2 c.35 (Friedberg 1:1325). See also Constans defensio 201. 
the chief Mystery, whose efficacy and power they truly represent, remains one Christ entire and true. ${ }^{56}$

Bucer noted that Gelasius had written this letter in 487 . He claimed, however, that this was also the meaning of "transubstantiation" taught by Lateran IV and Innocent III. ${ }^{57}$ The implication here was that Gropper's understanding of transubstantiation involved a Monophysite christology.

Bucer recognised, however, that sone of the patristic allusions to the transformation of the elements by a "prayer" referred to something other than the institution narrative. Like Gropper, Bucer did not explicitly entertain the possibility that the epiclesis of the Eastern Anaphora might be understood to have a consecratory function. ${ }^{58}$ He noted that when citing Basil De Spiritu sancto 27 , his

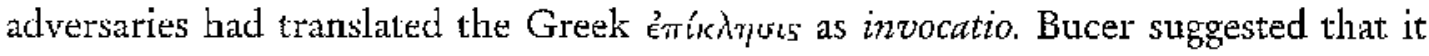
could also be translated as cognominatio: i.e. calling the bread and wine what they had become through Christ's word. Ps.-Dionysius, he wrote, described this as the,

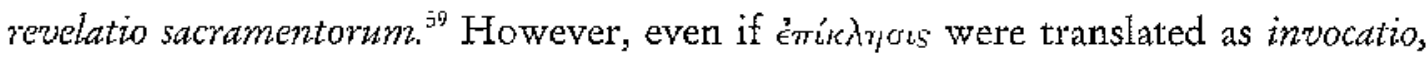
Bucer argued, this invocation of the Spirit was directed upon the ministers and

¿6 Ibid., 199, "Sacramenta quae sumimus corporis \& sanguinis Christi, diuina res est, propterea quod \& per eadem diuinae efficiuntur consortes naturae, \& tamen esse non desinit substantia vel creatura panis \& vini... vt sicut in hanc scilicet in diuinam transeant [i.e. corpus \& sanguis in Christo Domino], sancto Spiritu perficiente substantiam, permanente tamen sua proprietate naturae: sic illud ipsum mysterium principale cuius nobis efficientiam uirtutemaque ueraciter repracsentant: ex quibus constat proprie permanentibus, vnum Christum, quia integrum uexumque permanere demonstrant." Not in PL. Probably wia Johannes Sichard, Antidotum contra diversas omnium fere seculormm baereses... (Basel: Henricus Petrus, 1528), 233b. Eucharistic portion of treatise quoted in Kilmartin, The Eucharist in the West: Fistory and Theology (Collegeville, 1998), 4142. Constans defonsio, 200, adds that when the fathers speak of our own bodies taking on the flesh and blood of Christ, they do not mean that our own nature and substance is emptied out. Cf. Sichard, Antidotum, 2333.

${ }_{57}$ Constans defensio, 204 "... sinc dubio vcrus istorun [i.e. Innocenti III et Concilii Lateranensis] verbortm intellectus hic erit, guod sub pane \& vino, quae species stnt ac figurae corporis \& sanguinis Christi, verum corpus verusque sanguis Christi sit \& praebeatur: quodque ibi panis \& vinum transsubstantientur, transelemententur, \& essentialiter conuertantur in substantiam corporis \& sanguinis Christi, nempe sacramentaliter." Presumably via the canon Cum Marthae in Decrekales Gregorii IX 3, tit.41 c.6 (Friedberg 2:637-640, esp. 637) and DS 782. For Lateran IV, see DS 802.

${ }^{58}$ Though therc is no reason he should have been unaware of the differences between the Eastern and Western churches in this respect. The list of books in his possession at Y-Teidelberg 1518 (BCor 1:48) includes Bessarion's Oratio de sacramento encharistiae et quibus verbis Christi corpus perficiatur (1465). This had been published at Strasbourg in 1513 (BCor 1:55, 11. 56). See esp. Mohler $3: 49$.

${ }^{99}$ Constarts defensio, 323. It is not clear what words he is referring to in De bierarchia. In the discussion of transubstantiation (Constans defensio 198) Bucer uses the same argument in relation to Ircnacus, Adversus baereses 4.18.5 (PG 7:1208) "Quenadmadum pranis terrenus, accepta vocatione a. verbo Dei... notandum est quod dicit vocationem non invocationem" According to Roussean, 4.2:610,

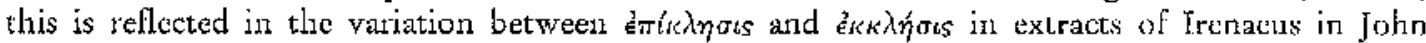
Damascene, Sacra parallela. Marg. note in Constans defensin, 198, "Sic Damasconus 1.4, c.14" not necessarily Bucer's own. Not traced in PG95-96. 
congregation rather than upon the gifts themselves. He noted that in the $\Lambda$ naphora of Basil and of John Chrysostom, the epiclesis occurred after the recitation of the words of Christ. 'Thus:

...if the representation of the body and blood of Christ depends entirely on his word, the faithful mind must nevertheless always pray, not only after the recitation of the words of consecration, but even after the bodily consumption of the sacraments is completed. For the sense here is not that the bread and wine or the accidents of the bread and wine hold Christ the true bread of heaven and food of eternal life, but that we, Christ's disciples, for whom this food was destined by Christ the Lord, may enjoy him. ${ }^{60}$

In other words, there was a kind of hiatus after the institution nartative and preceding communion in the Greek and Roman Canons. During it the minister and the faithful had to pray that faith would not desert them and that Christ would indeed present himself to them at the moment of communion.

For Gropper, on the other hand, the epicletic Quam oblationem marked the liturgical point of transition in which the church moved from offering the sacrifice of praise to offering the sacrifice of Christ. I-Ie demonstrated this with a sequential commentary on the prayers of the minor and major Canons. As we have already seen, the prayers of the minor Canon recalled the kindness of God in a significative offering of bread and wine. In recognition of this kindness the major Canon followed with prayers for the church, its leaders, for the living, and in commemoration of the saints (i.e. Te Igitur, Memento Domine, and Communicantes). The offering of the sacrifice of praise ended in the anacepbalosis or "summing up" of the Hanc Igitur in which the priest asked that God would accept the sacrifice of his people, grant them peace in their day, save them from final damnation, and count them among the number of the elect. ${ }^{\text {th }}$ Gropper noted that, like all the prayers of the Canon, the Hanc igitur ended per Christum Dominum nostrum. .? $^{2}$ The church, in other words, did not count on its own merits, but offered its sacrifice of praise through Christ.

In the Quam oblationem the priest sought that the sacrifice would be,

${ }^{50}$ Constans defensio, 324, "Ft si igitur exbibitio corporis \& sanguinis Christi verbis eitus penitus nititur, nihilominus tamen fidelis mens eam perpetuo orare debet non tantum post. recitationem verborm Consecrationis, sed etiam post corporalem sacramentorum sumptionem peractam. Non enim hic sensus est, quod panis \& vinum, vel accidentia panis \& vini Christum, verum panem coelestem, ac cibum vitae aeternae habeant, sed quod nos discipuli Christi, quihus hic cibum a Christo Domino destinatus est, co frui debcamus." Cf. Bucer's remarks an the elevation in the I.iturgy of John Chrysostom, BOL 3:202, "[sc. ut] per participationem et evangelicam orationem simus [i.e. participes] simus orat."

${ }^{61}$ Canon missa, Hanc igitur.

${ }^{62}$ Antididagma, $96 \mathrm{~b}$. 
"blessed, approved established, spiritual and acceptable so that it may become for us the body and blood of your most beloved Son our Lord Jesus Christ." Reciting the words of institution, the priest consecrated the sacrament in persona Christi. The cotascration ended with the words, boc facite in commemorationem meam. Then with the words, unde et memores:

Christ the Lord is offered anew (denuo) in the name of the whole church in an unbloody manner and through a spiritual representation and commemoration of his passion. This happens when the church proposes or represents the true body and true blood of Christ before the Father with thanksgiving and solicitous prayer for the salvation and for the sins of the whole world. ${ }^{64}$

Here he argued that the church did not attempt to reconcile itself with the Father by offering Christ through its own agency. ${ }^{65}$ Rather, it recognised itself as offered in the sacrifice of its Head present on the altar. Here Gropper appealed to the Augustinian exegetical principle underlying his understanding of eucharistic sacrifice: i,e. that what was attributed to Christ as the head of the body could also be attributed to his mystical body and vice versa. fir He cited Augustine's commentary on Psalm 21:2 (LXX) in which the words, Deus, Deus meus, respice me; quare dereliquisti were said to be spoken by the crucified Christ on behalf of his members. ${ }^{67}$ Gropper also quoted Augustine's mystagogical Sermo 272:

...the consecrated host is not only substantially the true budy and the true blood of Christ our head, but also signifies and represents the mystical body of Christ, i.e. the church, just as it is joined together

${ }^{63}$ Canon missae, Quam oblationem.

64 Antididagma, 97b-98a, "Christus dominus... denuo totius Fcclesiae nomine, moto incruento spirituali repraesentatione, \& commemoratione sacratißimae suae passionis offertur. Quod ipsum fit quando Ecclesia Christum \& eius uerum corpus uerumque sanguinem, Den patri cum gratiarum actione, \& oratione attenta pro salute \& pro totius mundi peccatis, proponit seu repraesentat." Again he quotes "Cyprian" De coena domini (i.e. Ernaldus Bonacvallis De cardinalibus operibus Christi (PL 189:1631)) "...110n minus hodic in conspectu patris oblatio illa sit efficax..." confirming that his understanding of the Mass remained "Thomist." See above, ch. 7, p. 128.

${ }_{65}^{6}$ Antididagma, 99b, "P'rocul a nobis absit ut talis sensus aut cogitatio nobis in mentem ueniat, quasi nos miseri peccatores uelimus nostra actione corpus \& sanguinem Domini lesu Christi Patri primum concillare \& accepta reddere."

${ }^{66}$ See De doctrina christiana 3.30-37 (PL 34:81-90) which describes this as the first rule of the Donatist exeyete Tychonius. According to the second rule (ibid, 82-83) this only applicable to the corpus Cbristi mysticum. E.g. Cant 1:5, "Nigra sumn..." refers to the corpus Christi bipartitum, i.t. the corpus permixtum or, worse, simulatum which includes the heirs of both Isaac and Ishmael (Gal 21:10)

${ }^{67}$ Antididagma, 99b, "Quarc.. boc dicitur nisi quia nos ibi eramus, nisi quiat corpus Cbristi Ecclesia. Debent \& hic ad eundem modum uerba illa intelligi, ut Deus super hunc sanctum panem $\& x$ calicem salutis aspicere dignetur, quatenus panis ille sanctus \& calix salutaris nos simul comprehendit. Vuus enim panis, ait Apostolus, \& unum corpus..." See Ennaratio in Ps. 212 (PL $36: 172)$. 
both in head and members... As the blessed Augustine teaches on the sacraments: "the mystery of yoursclves lies on the altar; you reccive the mystery of yourselves; you respond 'Amen' to what you are yourselves. Be a member of the body of Christ so that your 'Amen' may be true. ${ }^{68}$

As already noted, Bucer had cited this same passage in his Bericht. There, however, he had distinguished between the res received by members of Christ's mystical body and the sacramentum received by those who belonged to the body outwardly only. As in the Worms-Regensburg Book, the difference between Bucer and Gropper lay in their disagreement as to what was present "on the altar."

For Gropper the substantial conversion of the significative sacrifice of the church, the elements of bread and wine, was an objective pledge that the church's imperfect obsequizm servitutis was acceptable to God the Father through the perfect sacrifice of Christ. The prayers which followed the consecration cxpresscd the church's recognition of this fact. In the Supra quae propitio, the Canon asked the Father to accept the church's offering as once he had accepted the sacrifices of Abel, Abraham and Melchizedek. ${ }^{69}$ Gropper argued that this was not to suggest that the sacrifices of the patriarchs were accepted on their own account or because of their offerers' merit. Rather, they were accepted on account of Christ whom they signified, and their offerers' obedience to the divine mandate to offer sacrifice. Likewise, the church asked God the Father to accept the holy bread and saving cup, "not because of its most blessed head who presents himself there, but because of ourselves, who by this mystery show ourselves to be also one bread with Christ." Again, although the sacrifice of Christ was already perfect and sufficient, the church sought to be united more perfectly with Christ, as it already was in mysterio.

E8 Antididagma, 95b-96a, "... hostia consecrata, non tantum est vetum cotpus \& uerus sanguis capitis nostri Christi substantialiter, uerumetiam corpus Christi mysticum, hoc est Ecclesian, sicut cx capite \& membris simul conexa est, significat \& repraesentat... sicut beatus Augustinus tradit de Sacramentis: Mysterium (inqtuit) zestrum iacet in altari, mysterim restrim. stumitis, ad quod ipsi estis, Amen respondetis. Esto membrum corporis Christi, ut Amen tunm sit uertm." Cf. Augustine, Sermo 272 "ad infantes de sacramentis" (PL 38:1248), "Mysterium vestrum in menst Domini positum est, naysterium vestrum accipitis..." [emph. mine].

69 Antididagma 100:-100b. Also cites refs. to Abel, Noah, Abraham, Moses, Aaron and Samuel in Liturgy of Basil (Brightman, 401); Chrysostom's Orationes adriersus Ludaeos "in eos qui cum Judaeis ieiuniant" 2.3 (PG 48:860) is cited to the effect that the prophetic dernunciation of the Old Testament cult was not a rejection of sacrifices as such, but of the spirit in which they were offered.

${ }^{70}$ Antididagma 100a-100b, "... sacrificia illa Patrum propter Christum atique designabant, denique \& propter mandatım Dei sacrificia illa requirentis, non poterant ipsa non placerc: \& tancrn quod ad corum obedientiam attinebat, quam in sacrificando Deo exhibebant, in sacrificijs illis figuralibus orabant, quemadmodum \& nos, ut Deus dignaretur ea accepta habere. Itaque panis sanctus \& calix salutaris, non ratione capitis superbenedicti illic se exhibentis (in quo Patri semper bene complacuit) sed ratione nostri, qui illic quoque unus cum Christo panis esse, mystice significanur, \& quatcnus nos ea offerimus, accepta haberi petuntur." 
In the following prayer - Supplices te rogamus - the words of the Canon asked that the Father bid his angel bring the sacrifice to his heavenly altar. Gropper wrote that no-one should imagine that the body and blood of Christ were now being brought before the Father for the first time. The "angel," had a double significance. Tobit 12:12 referred to the archangel Raphael presenting the supplications of Tobias and Sarah before God in glory. "Thus the "angel" in the Canon referred, first of all, to the angelic presentation of the prayers of the church at God's heavenly altar. This was confirmed with the citation of a similar prayer in Ambrose's De sacramentis 4.6 which spoke of "angels" in the plural rather than the singular." Gropper, however, noted that the Supplices spoke of one "angel." Understood in this way, the angel was Christ. Here he cited a prayer, allegedly in the "Greck Canon," which referred to Christ as the, "Angel of great counsel" (cf. Isaiah $9.5(\mathrm{LXX})$ ) offering the sacrifices of the church to the Father on the altar of his humanity. ${ }^{73}$ Every spiritual sacrifice which Christians offered, whether of faith, of devotion, of thanksgiving, of vows, of prayers, of hope or of love, must be offered to God the Father in and through Christ (1 Pet 2:5). ${ }^{74}$

In Cunstans defensio and in De vera et falsa. Bucer was at pains to distinguish between the two senses in which this "offering of Christ" was "represented." Representation in the "strong" sense was confined to the catabatic dimension of the Eucharist: i.e. the preaching of the sacrificed Christ to the faithful and their reception of him in communion. Representation in the anabatic sense (i.e. to God the Father) was figurative or "weak." In Constans defensio he wrote that in the Supper there was no "proposing or representing" Christ to God the Father beyond the prayer of thanksgiving. Nor was this representation one by which the church

${ }^{71}$ Antididiagma 102a. Cf. also Psalm 78:11 (LXX); Ps 87:3 (LXX); Sira 35:17 [i.e. 35:8?].

${ }^{72}$ Antididagma 102a. PL 16:464, “... per manus angelorum tuorum..." Gropper also cites "Augustine In Tohannem" via Decretum Gratiani 3 de consecr. dist.2, c.59 (Friedberg 1:1336) and the reference to the "high-heavenly and intellectual altar" either in the Liturgy of John Chrysostom, Lord's Prayer or Basil, Proskomide (Brightman, 390, 401).

${ }^{73}$ Antididagma 101a-101b, The prayer which I have been unable to find in Brightman or elsewhere reads: "Omnipotens Deus, cun probe scianus mysticam hanc nostran oblationem corporis \& sanguinis dilectißimi filij tui, quam tibi sub panis \& uini figuris in terreno isto altari exteriori operatione offerinus, beatißinam eius paßionem tibi rursus figuraliter proponens, cum immensa gratiarum actione, propter indignitatem nostram tibi placere non posse. Idcirco supplices roganus, ut per eum ipsum, qui est magni consilij angelus, endem illa tibi offeratur in sublime tuum altare hurnanitatis eius, quam super omnes coelos cxaltasti, \& ad dexteram tuan collocasti quo sic ad nostram reconciliationem semper in conspectu apparcat \& luceat."

${ }^{74} \mathrm{Ibid} ., 102 \mathrm{a}$ also cites Exod 23:20-23 (angel as type of Chrisi) and Heb 13:10-16 \& Rev 8:3-5 (Christ as heavenly altar'. Supported with Augustine De Trinitate "10," presumably 3.10 (PL 42:880) (rc. Cod speaking in the person of an angel in Exod 3:6); De fide ad Petrum (PE 40:22) (re. Christ as priest, sacrifice, altar and temple); Enarratio in Ps. 25.[10] \& 26.[12] (PL 36:193, 205-206) "Algcr of Liège," probably De sacramentis corporis et sanguinis domini 1.14 (PL 180:781) "...ostcndcns [i.c. "Supplices"] ipsum Filium, jussione Patris in coelis esse offerentem, et hostiam, et id super quod offertur ..." 
"set" Christ before the Father. ${ }^{75}$ Here he distanced himself explicitly from the use of vorstellen/sistere in the Leipzig and Worms-Regensburg formulae. Even in De vera et falsa, where Bucer re-appropriated the language of anabatic representation, he disparaged his adversaries' use of sistere as the "Cologne conjuring trick" (prestigium Coloniensem):

"set him before the Father as the victim for our sins?" - a phrase which those at Cologne have wrongly appropriated. He is exalted at the right hand of the Father and, seated there forever, he sets and presents (exbibet) us to the Father. "Ask the Father that he be pleased with the sacrifice of his Son?" Yet it is on account of that very sacrifice with which the Father is most pleased that he favours us in his beloved Son. ${ }^{76}$

This, in effect, was what Gropper bad said in the Antididagma, but for Bucer his adversaries' insistence on substantial conversion could only imply a new offering of Christ.

In order to demonstrate that the primary representation of Christ was to the faithful, Buccr citcd Augustine's Enarratio in Psalmum 75. This was the second of the patristic texts which Bucer described as fundamental to his argument on the Mass in Constans defensio. ${ }^{77}$ In fact the passage was quoted in full only in De vera et falsa:

Brothers, see that Christ has indeed renewed us, forgiven us all our sins, and that we have been transformed. If we forget what was forgiven us and by whom we were forgiven, we forget the saving gift [or gift of the Saviour]. Yet because we do not forget the saving gift, is not Christ sacrificed to us [immolatur nobis] daily? Christ was also sacrificed once for us [immolatur pro nobis]. When we believed, that was something we acknowledged. Yet the memory of him who came to us and of what he forgave us are only the remains of that acknowledgment, and out of the very remains of that acknowledgment, in other words, out of that very memory, he is

${ }^{75}$ Constans defensio 309, "In hac oblatione Christi nulla est propositio vel repraesentatio Domini nostri lesu Christi, per quam Deo Patri proponatur, \& representetur, praeter id quod ibi summas illi gratias agere debernus... At haec non est propositio vel reprnesentatio Filij Dei qua ipsum Patri sistamus vel repraesentemus: sed multo magis receptio ipsius Domini nostri, qui nobis ibi a Patre ministerio S. officij, vha cum sacrosancto Evangelio \& sacramentis proponitur, ac repraesentatur." See also ibid. 275.

${ }^{76}$ De vera, 181, 'Sistere eum patri hostiam salutis pro nobis? quod Colonienses perperan arripuerunt. At ille ad dexteram patris exaltatus, \& sedens perpetuo sistit, \& exhibet nos patri. Rogare patrem, ut sacrificium filij factum habeat gratum? At propter hoc ipsum sacrificium, quia gratissimum habet pater, gratos nos facit in dilecto tilio suo."

${ }^{77}$ Ibid., 341. 
immolated to us daily. It is as if he who renewed us by his first grace, renews us daily. ${ }^{78}$

Here Bucer posited a distinction between immolatur nobis (i.e. "sacrificed to us") when speaking of the Lord's Supper, and immolatur pro nobis (i.e. "sacrificed for us," or "on our behalf") when speaking of Christ's death once on the cross appropriated in Baptism by faith. For Bucer, the distinction demonstrated that Christ was not offered "to the Father but that he is proposed and handed over to us for our benefit."

Bucer's nobis/pro nobis distinction is borne out in the contemporary versions of Augustine's Enarrationes in Psalmos which I have been able to consult. ${ }^{80}$ Gropper had also used this passage, but he had paraphrased and mis-cited it: "Christ was offered once for us. Yet, if we believe and remember that he came to us, he is daily offered for us (pro nobis) as if he who renewed us with his first grace, rencws us daily." Modern editions of Augustine's Enarraitones strike a via media between the two, using immolatur nobis for both the crucifixion and the Eucharist. ${ }^{82}$

In both Conslans defensio and De vera et falsa Bucer supported his reading of Enarratio in Psalmum 75 with further Augustinian passages. In Epistola 98 "to Boniface the bishop," he found the phrase populis immolatur used again to describe Christ's "immolation" in the Eucharist and distinguished from his immolation in seipso on the cross. ${ }^{83}$ Citing Contra Faustum 20.21, (Huius sacrifici curo et sanguis... per sacramentum memoriae celebratur) he wrote:

${ }^{78}$ De vera, 176-177 (incorrectly cited as Augustine, In Ps. 78): "Eutenitn fratres mei, ecce innouaut nos Christus, donauit nobis omnia peccata, \& conuersi sunus. Si obliniscannur quid nobis donatum est, \&x a quo donatum est, obliuiscimur munus salutaris [sic]. Cum autem non obliuiscimur munus salutaris [sic], nonne qutotidie nobis Christus inmolatur? Et semel pro nobis Christus immolatus est, cutn credidimus, tunc nobis fuit cogitatio, modo autem reliquiae cogitationis sunt, qua meminimus, quis ad nos uenerit, \& quid nobis donaterit, ex ipsis reliquijs cogitationis, id est ex ipsa memoria, quotidie nobis sic immolatur, quasi quotidie nos innouet, qui prima gratia sta nos innouauit."

${ }^{7}$ Constuns defensio, 308, "Verum, non dicit, Quod Patri, sed quod nobis offeratur, hoc est, ad fruendum proponatur \& tradaur..."

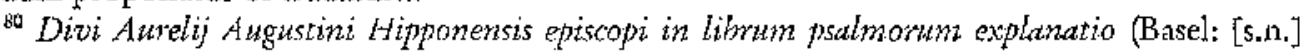
1489), fol. $P_{4} 4_{1} ; D$. Aurelit Augustini Hipponensis, cuitus prastantissima in ommi genere monimenta... 10 v. (Basel: Hroben, 1569), 835. These differ from Bucer's text only in their use of munus saluatoris where, perhaps due to a printing error, Bucer's text uses munus salutaris [i.e. salutare]

".i Antididagma 98b, "Semcl pro nobis Christus oblatus est: si credinus autem \& commemoranus quia uenit ad nos, quotidie offeratur pro nobis, ac si renouet nos quotidie, qui nos prima gratia sua renouauit." The reference given in the Antididagma is incorrectly given as Augustinc, In Psalm 55. There is no similar passage in Enarrationes in P. 75 (PL 36:646-661).

${ }^{82}$ Sce PL 36:966; CCSL 39:1047, 6.

${ }^{83}$ Constans defensio, 275 cites (bur does not quote) Epistola 98 (PL 33:363-364), "Nonnc semel immolatus est. Christus in seipso, et tamen in sacramento non solum per omnes Paschac solemnitates, sed omni die populis immolatur... Ex hac autem similitudine plerumque stiam ipsarum rerum nomina accipiunt." 
Here you see that to offer this sacrifice of Christ, or Christ himself, is the same thing for Augustine as celebrating him, i.e. preaching him by word and sacrament, presenting the memorial of Christ and his death. ${ }^{84}$

Bucer did admit to finding mention of the church offering the body and blood of Christ "to the Father" in Augustine's Quaestiones evangeliorum 2.33. ${ }^{85}$ However he produced another passage from "Augustine" ( in fact Fulgentius of Ruspc) De fide ad Petrum 18 which referred to the church offering a sacrifice of bread and wine to the Father with the Son and the Holy Spirit.. ${ }^{86}$ The Son could not be offered his own body and blood, Bucer concluded; he could only be thanked for having offered them. Offering "to the Father" must mean the same thing: i.e. the Father was thanked for the sacrifice of the Son. ${ }^{87}$

Thus the Lord's Supper was the sacrament of the body and blood of Christ in so far as Christ distributed these to his disciples with the "sacraments" of bread and wine. Yet, in two of the patristic texts underlying this debate, the Last Supper was described as the institution of a sacrifice. In Adversus Haereses 4 Irenaeus described it as the institution of an offering of bread and wine. ${ }^{89}$ Likewise in his Epistola 63 Cyprian claimed that Jesus had fulfilled the priesthood of Melchizedek by offering bread and wine, scilicet corpus et sanguinem. ${ }^{89}$ Thus:

because we make mention of his passion in all our sacrifices (for the passion of the Lord is the sacrifice which we offer) we must do nothing

${ }^{34}$ De vera, 176, "Hic uides offere hoc sacrificium Christi, atque Christum ipsum Augustino iden esse, atque celebrare, hoc est, uerbis \& sacramentis predicare, atque exhilsere memoriam Christi \& mortis eins." See also Constans defensio, 274. See above, ch. 8, p. 146.

${ }^{85}$ De vera, 177. See PL 35:1346, "Et islac cpulae... (Cf. Matt 15:11-32) nunc celebrantur, per orbem terrarum Ecclesia... Vitulus enim ille in corpore et sanguine Dominico et offertur Patri, et pascit totam domum." Bucer describes this as liber adscriphus Augusino.

${ }^{86}$ Constans defensio, 274; De vera, 177-78. Cf. PL 40:772, "Firmissime tenc, et. nullatenus dubites ipsum unigenitum Deum, Verbum carnem factutrn, se pro nobis obtulisse sacrificium, \& hostian Deo in odorem suavitatis; cui cum Palre, ct Spiritu sancto a Patriarchis, prophetis, et sacerdotibus tempore Veteris Testamenti animalia sacrificabantux: ct cui nunc, id cst, tcmporc, Novi Testamenti cum Patre et Spiritu sancto, cum quilsus illi est una divinitas, sacrificium panis \& uini in fide et charitate sancta Ecclcsia catholica per universum orbern terrae offerre non cessat." PL 40:752. Also in PL 65:671-705.

${ }^{87}$ Constans defensio, $274 ;$ De vert, 178.

${ }^{88}$ PG 7:1023, "Sed et suis discipulis dans consilium primitias Deo offerre ex suis creaturis... cum qui ex creatura est panis accepit et gralias egit dicens: Hoc est mettm corpus. Et calicem similiter, qui cst $\mathrm{cx}$ ca creatura quae est secundum nos, suum sanguinem confessus est novi Testamenti novam docuit oblationem; quan Ecclesia ab Apostolis accipiens in universo mundo offert Deo, ei qui nobis praestat, primitias suorum munerum in novo Testamento.

89 PL 4:387, "Item in sacerdote Melchisedech sacrificii Doninici sacramentum pracfiguratum videmus... quod Melchisedech sacerdos Dei sumni fuit, quod panem et vinum obtulit, quad Abraham benedixit. Nam quis magis saccrdos Dei summi quam Dominus noster Jesus Christus, qui sacrificium Deo Patri obtulit, et obtulit hoc idem quod Mclchiscdech obtulerat, id est panem ct vinum, suum scilicet corpus ct sanguinem?" 
other than what he did... As often, therefore, as we offer this cup in commemoration of the Lord and his passion, we do what the Lord is held to have done...9

This was the third of the patristic texts which Bucer described as Iundamental to his case, but in Constans defensio at least, he seems to have been uncomfortable with its implications. Cyprian was, he wrote, speaking in a "sublime" and "cnlarged" manner. What he and the other ancicnt fathers were really saying was that:

in the Holy Supper, if we celebrate it in accordance with the institution of the Lord, we have present and receive to our eternal life our Lord Jesus Christ, the single sacrifice acceptable to God the Father. In him we also offer ourselves to the Father and we are offered through him, and we give thanks, and we celebrate with our praises. All of these are worship agreeable and acceptable to God, and a pleasing work. ${ }^{21}$

In De vera et falsa, however, Bucer tackled the sacrificial nature of the Supper's institution with greater confidence. As we have already noted, Bucer introduccd a new sacrifice to the four which structured the argument in Constans defensio. This was the offering of the sanctified bread and wine set aside from the gifts of the faithful for the use of the sacrament. Returning to Cyprian's account of the institution in Epistola 63, Bucer acknowledged the propriety of describing it as an "offering" if it meant that:

when [Christ] made an olfering as high priest of God the Father, he took bread and wine, the gifts of God, and like the priest before God with the assembly then gathered around him, he gave thanks to the Father. And, together with teaching, prayers and hymns, he blessed [the gifts] for the wholesome use of the sacrament, and distributed them so that he might present his disciples with a life-giving

90 Thid., 389, "Fit quia passionis eitus mentionem in sacrificiis omnibus facinus (passio est enim Domini sacrificium quod offerimus), nihil adiud quam quod ille fecit facere debemus... Quotiescunque ergo calicem in commemorationem Domini et passionis eius offerimus, id quod constat Dominum fecisse faciamus..."

91 Constans defensin, 272, "Similes inueniretur fere apud omnes antiquos Patres, verum in nullo alio sensu, quam quod multum amplificare ac sublimibus verbis pronunciare voluenunt id quod in S. Coena, si modo eam iuxta institutionem Domini celebremus, praesens habennus, \& ad vitam aeternam percipimus, videlicet Dominum nostrum Issum Christum, vnice acceptum Deo Patri sacrificium, In quo nos ipsos quoque Patri offerimus, \& offerimur per ipsum, gratias illi agemus, laudibusque celebramus, quae amnia sunt gratus \& acceptus Deo cultus, opusque beneplacitum." 
communion with himsclf and his merit, and stir them to a blessed memorial of him. ${ }^{2 / 2}$

Bucer now applied this priestly-sacrificial paradigm to the sequence of prayers in the Roman Canon as Gropper had done in the Antididagma. In Constans defensio he had treated the prayers of the Canon with suspicion. He noted that in the eucharistic prayer of Ambrose's De sacramentis, the Quam oblaionem described the offering of the church as a "figure" of the body and blood of Christ. Hence, Bucer had concluded, the oblatio referred to must have been the prayer with which the body and blood of the Lord were commemorated. ${ }^{93}$ Turning to the Unde et memores he had emphasised its memorial of the Lord's passion, but of its relerence to the "holy bread of cternal life and che cup of everlasting salvation," the most that he was prepared to say was that the prayer could not refer to the consecrated elements. ${ }^{94}$ In De vera et falsa, however, Bucer acknowledged that the Unde et memores of the Roman Canon did in fact refer to the bread and wine taken from the offerings of the faithful. These now lay on the altar, and were set apart for the usus sacrament $i$ by the recitation of the institution narrative.

Although the Antididagma had identified the first-fruits offering of Deuteronomy 26 as a type of the Eucharist, this had received no comment in Constans defensio. In De vera et falsa, however, Buccr sccms to have taken his cue from Gropper and used both Adversis baereses 4 and Deuteronomy 26 to demonstrate that the Unde et menores and subsequent prayers of the Roman Canon had once carried a wholesome sense. According to Bucer, the first-fruits offering had manifested the people's liberation from slavery both to Pharaoh and to superstition and impiety; it had celebrated the giving of the law; and it looked to the coming of the promised Christ. The priests and people thanked God for all his benefits, resolved to tuse his gifts in a wholesome manner, and then enjoyed them in his presence. They also set some aside for the use of thc widows, the Levites and the poor. This, he wrote, was worship pleasing to God. Similarly in the Lord's Supper, the bread and wine and the prayer said with them represcnted the sacrificial death

${ }^{92}$ De vera 172-173, "cum ipse summus sacerdos Dei patris obtulit, Panc \& uino, donis Dei, in manibus sumptis, ac ita ceu in conspectum Dei, \& eius suac Ecclesiac, quan tum collcctam apud se habet, prolatis, egit gratias patri. Et in salutarem usum sacramenti ca, quo uiufificann sui \& meriti sui communicationem discipulis exhiberet, \& beatam sui commemorationem excitaret, \& sanciret, sanctificauit, \& distribuit, adiuncta doctrina, precibus, \& hymnis."

${ }^{9}$ Constans defensio "342" [332] "Sic enim in eo loco legitur: "Fac nobis hanc (Orationem) inserted here to clarify Bucer's reading] ascriptam, rationabilem, acceptabilem: quod est figura corporis \& satguinis Domini nostri Iesu Christi.' Consimilis ratio est verborum illius precationis, quam statim a Consecratione dicunt. Vnde et memores..." Cf. Ambrose, De sacramentis 4.5 (PI) $16: 462)$.

$$
{ }^{94} \text { Constans defensio. "342" [332]-333. }
$$


of Christ and showed the faithful that he is the food of eternal life. ${ }^{95}$ Irenaets, he claimed, had written in a sinilar vein: "we offer him what is his, proclaiming in a firting way the communion and the unity of the spirit and flesh."

This, in effect, is Bucer's explanation of the phrase, "on the altar" and of the Unde et memores. The elements, as well as the prayer, are called the, "bread of life" and the "cup of eternal salvation" in an anticipatory sense, i.e. because they will he received as such by the faithful. They are not, as Gropper would have it, transubstantiated, but in De vera et falsa Bucer seems to have admitted the notion of a significative sacrifice and a kind of transformation whereby the offered bread and wine were named as the sacramental representation of the body and blood of Christ for the faithful.

Bucer argued that the prayers following the consecration and Unde et memores (i.e. Supra quae propitio and Supplices le rogamus) continued to refer in their most fundamental sense to the church's sacrificc of thanksgiving and praise. Apparently taking his cue from the Antididagma he compared the reference to the Angel and the heavenly altar in the Supplices with the dcacon's exhortation in the Liturgy of John Chrysostom:

For the precious gifts which have been offered and sanctificd let us pray to the Lord... that our most clement Lord, who accepts them in his holy, high-heavenly and intellectual altar as a sweet smelling spiritual sacrifice, may return to you divine grace and the gift of the most holy Spirit. ${ }^{77}$

Likcwise, he argued, the Supplices anticipated that a portion of the gifts brought to the Supper by the faithful would return to them as sacraments of the body and blood of Christ filling them, "with every heavenly blessing and grace." Here Bucer noted the emphasis in the Eastern Anaphora on "spiritual worship" (Rom 12:1). There was, he claimed, no distinction made in the Liturgy of John Chrysostom between this offering of gifts on the "intellectual altar," and an

${ }^{95}$ De vera, 167, "Verum cum offerent sancti suas oblationes, fam eas esse doria Dei, \& esse quoque in manu $8 x$ in conspectu Dei, religiosius considerabant, de cisque gratias Deo per Christurn Dominum agebant religiosius, eaque iam uelut e manu Dei suscipicbant, \& stra quoque professione gloriae Dci, diuinisque usibus (ut Irenei uerbo utar) decernebant, denique in hunc usum sanctificari ea sibi precabantur, ac etiam tsurpabant, seseque iuxta Deo in onne obsequium sistebant \& consecrabant."

${ }^{96}$ Ibid., 173, "Offerimus enim ei quae sunt eius, congruenter communicationem et unitatem praedicantes carnis et spiritus." Cf. Irenaeus, Aiversus baercses 4.18.5 (PG 7:1028-1029)

${ }^{77}$ De vera, 160-161, "Pro oblatis \& sanctificatis praeciosis donis deprecenur Jominum... Vt clementissimus Dominus noster, qui accipit ipsa in sanctum $8 x$ supercoeleste, ac intellcctuale suum altare, in odorem suauitatis spiritualis, renitlat uicissin uobis diuinarum gratiam, \& donum sanctissimi spiritus..." Liturgy of John Chlysostom, Lord's Prayer (Brightman, 390). Cf. BOL 3:202. 
offering of incense which, elsewhere in the Liturgy, was offered on the same altar. ${ }^{98}$ Thus, in the Roman and Grcek Canons properly understood, the minister of the church prayed on behalf of the offerentes that their spiritual sacrifices, signified in gifts of bread and wine, might be acceptable to God. Buccr explained the Roman Canon's references to the acceptability of the sacrifice on the heavenly altar by quoting from Augustine's De civitate Dei 10.6: "in the offering which she makes, she herself is offered." ${ }^{\text {99 }}$ Bucer also noted that in the Liturgy of John Chrysostom the priest prayed, "For you, O Christ our God are the offerer and the one who is offered, the who takes up and the one who is distributed, and to you we give glory with the Father. ${ }^{n 100}$ As in Adversus Axioma catholicum, Bucer aclsnowledged the propriety of speaking of Christ as the eternal High Priest who is active in presenting the sacrifices of the church to the Father, as long as it was recognised that in the Supper the cburcb did not "represent" or "set" Christ before the Father except in so far as it offered prayers of thanksgiving and praise through, with and in Christ to the Father.

\subsubsection{The Offering of the Church}

\subsubsection{The Opus Operatum and Its Application for Otbers}

We have already noted the Antididagma's insistence that "invocation of the divine name" was necessary for the valid consecration of the sacrament. In addition to its association in Gropper's mind with substantial conversion, this invocation guaranteed that the priest consecrated as a minister of the catholic church and in the sense intended by it. ${ }^{151}$ In Baptism, he argued, the minister did not simply read an account of the institution, but said Ego te baptizo etc. Likewise, the validity of the Eucharist depended not only on the minister recounting what Christ had said, but on his doing what the catholic church held Christ to have done.

However, while the minister's use of the Canon signified this intention, he

De vera 164, "Incensum tibi offerinus Christe Deus, in odorem suauitatis spiritualis, quam suscipe Domine in sanctum \& supercoeleste ac intellectuale tuum altare, \& repende nobis opes misericordiae tuae, \& miserationes eas." Sec Liturgy of John Chrysostom, Prothesis (Brightman, 359). Cf. BOL 3:199 for the incense offering and ibid. 199-208 passim for various underlined references to the high-heavenly and intellectual altar.

g" De vera, 162-63, "De hac scripsit Augustinus.. 'Hoc est,' inquit, 'sacrificum Christianorum, multi unum corpus sumus in Christo: quod etiann sacramento altaris fidelibus noto frequentat Lcclesia, ubi ei demonstratur, quod in ea oblatione quem offert, ipse offeratur."; PL $41: 284$.

${ }^{100}$ De vera, 166, "...huius offerentem confitetur sacerdos esse Christi ipsius, non se. Ait enim, 'Tu, enim, o Christe Deus noster es offerens, \& is qui offertur, \& qui suscipit, \& grii distribuitur, \& tibi gloriam damus cum patre. \&.c." See Liturgy of John Chrysostom, Prayer of the Chertabic Hymn (Brightman, 378). Cf. BOL 3:202.

${ }^{101}$ Antididagma, 112b. 
consecrated, "not with his own words, but with the almighty words of the Lord Jestus Christ:" ${ }^{102}$ Thus the minister consecrated not principally as a minister of the church, but in persona Christi tanquam minister eits. ${ }^{103}$ Again, for Gropper the opus operatum in the Mass was:

not the outward actions of the priest, but the work of God in the consecration and sanctification of the sacrament. This does not depend on the merit of the priest but on the power of Christ who cruly consecrates his sacrament himself, confects it and dispenses it to the people, but through the ministry of the priest, no matter how bad or unworthy he may be. ${ }^{104}$

As in the Incbiridion, Gropper distinguished between this perfect work of Christ and the oblatio in which the church presented its prayer through the priest tanquam minister publicus. Here Gropper noted that, according to the scholastics, the efficacy of the offering was dependent on the moral condition of the priest speaking on the church's behalf. However, he insisted that this limited only the benefits gained by the priest bimself. The story of Balaam (Numbers 22-23 via Augustine, Contra epistolam Parmeniani 2.8) suggestcd that God heard the prayer of sinners for others. 'Thus the efficacy of any priest's oblatio for other beneficiaries was limited only by their devotion. ${ }^{105}$ The Mass was a representative sacrifice "applicatory" of the remission of sins "promerited" through Christ's sacrifice, and each person applicd this remission to him or herself through faith (or in the case of the faithful departed, through the meritum fidei acquired while they lived). ${ }^{106}$ The

${ }_{102}$ Ibid.,112a, "sacerdos Ecclesiac minister, cum inuocatione noninis diuini proposita dona benedicat \& sanctificet, non utique suis, sed omnipotentibus donini nostri lesu Christi uerbis." pronunciat."

${ }^{103}$ Ibid, 113a, "Quae verba deinde it2 persona Christi, tanquam minister eius prosequitur \&.

${ }^{10.1}$ Ibid.,110a, "Innocentius enim tertius... \& scholastici doctores omnes in 4 sententiarum per opus opcratum sacrificium altaris intelligunt in non externns sacerdotis actiones, sed opus Dei in consecratione \& sanctificatione sacramenti: Quod non a merito sacerdotis, sed a Christi potentia dependet: qui sacramentum suum ipse ueraciter consecrat, sonficit, \& fidelibus dispensat: quanquam ministerio sacerdotis, lice mali nonnunquam $8 x$ indigni. " Cf. Innocent XII, $D z$ sacro altaris mysterio 3.5 (12L 217:844); Lombard, Sententiae 4 d.13 4.1 (PI, 192:867).

${ }^{105}$ Antidiagma 110a-1101, “... scholastici inter opus operatum \& opus operans hanc faciunt differentiam; Prits illud dicunt cum sit opus solius DEI \& CHRISTI non consistens in oblatione, sed in sacramenti consecratione \& sanctificatione, semper purum esse \& sanctum. Licet permittat nonnunquam Deus externe tractari illud manibus sacerdotis sicut enim... hic est qui baptizat Christus, ita hic est qui sanctificat ad altarc... Nhterum uero opus operans, quod... consistit in... oblatione sacrificij, in gratiarum actionc, orationibus"; Citing Jerome, Contra Luciferianos (PL. 23:163-192) (probably via Decretum Gratiani 2, causa 1., qu.1, c.75 (Friedberg 1:384-385); "Augustine" in Decretion Gratiani 3 de consecr. dist.2 c.72 (Friedberg 1:1343) (In fact Paschasius, De corpore et sangutine domini 12 (PL 120:1310). "Reliqua omnia... nichil aliud quam laudes et gratiarum actiones sunt, aut certe obsecrationes et fidelium petitiones." Augustine, Contra Parmenianum 2.8 (PI 43:60-61) re. Balaam.

106 Antididagma 109a-109b, "...summatim dicamus, Christi sacrificium est meritorium remissionis, repraesentatium Missae sacrificiun est promeritae redemptionis applicatoriun, quod 
scholastics, Gropper wrote, had never taught that these benefits could be gained without faith. ${ }^{107}$

In Constans defensio Bucer attempted to identify the common ground between himself and his adversaries. He conceded that the priest "in some sense assimilates himself" to Christ by reciting the words of consecration and distributing the sacrament. ${ }^{108}$ Here his principal authority was Ps-Dionysius' Hierarcbia ecclesiastica 3.12 which referred to the priest's "imitation of the divine ministry"

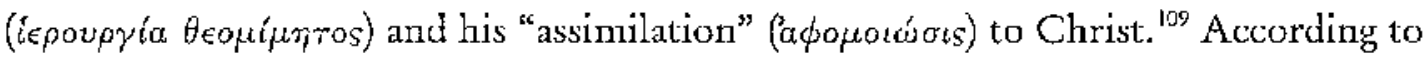
Bucer, this imitation and assimilation lay chiefly in the recitation of Christ's words of institution. However the priest also assimilated himself to Christ by doing as he did: i.e. taking bread and wine, showing them to be his body and blood, offering thanks and praise to God, and distributing the sacraments to the people. ${ }^{110}$

Thus, when the Supper was celebrated according to Christ's institution and properly enjoyed, it was also rightly called, "a good and saving work." The grace of the sacrament depended in no way on the minister opus operans, but on the work of Christ who offered this grace when his ordinance was observed. It was necessary, however, that the faith of the opus sumens (Bucer's own phrase for the communicant) be brought to the Supper for its effect to be enjoyed. 'l'his faith neither merited grace nor added anything to the work of Christ. ${ }^{111}$

Thus Bucer and his adversaries agreed that the church and its ministry exercised some agency in mediating Christ's work. Bucer was careful to point out that there were two kinds of application in the Supper. Firstly, individuals applied the redcmption and merit of Christ to themselves by means of their faith. Secondly, through word and sacraments, the priest applied and delivered redemption and

eo applicet sibi quisque per fidem remissionem illan; quod \& in defunctis obtinct, cui dum uiucrent sibi hoc meriturum per fidem propriam compararunt, ut ipsis haee post mortern prodesse possent." 10? Ibid., 110b-111a, "Quin potius docuit [i.c. ccclesia], opus illud in sequale est considcratum, nemini conferre [i.c. remissionem peccatorum]. Quapropter sententia contraria doctoribus scholasticis inciuiliter, imo malitiose per quosdan affingitur."

${ }^{108}$ Constans defensio, 321, "Deinde cum precatus est, vt idoncus factus huic administrationi qua Deum imitatur, diuina dona, quadam sui ad Christum ipsun assimilatione, valcat perquam sancte, tum perficere, tum distribuere."

${ }^{101}$ PG 3:442CD.

${ }^{110}$ Constans defensio, 321.

${ }^{111}$ Ibid.,318, "Alioqui verum est S. Coenam iuxta institulionem Christi administratam, per se bontum ac salutiferum opus esse omnibus qui ea rite vtuntur: etiam si sacerdos omni fide destitutus sit, modo poptulus sine propria culpa id ignoret... Omnis enim gratia in sacratnentis nullo modo ex opere operantis ministri, sed ex opere operato Christi, quod ibi iuxta verbum et mandatum illius praebetur, proficiscitur. Nihilominus tamen opus operantis sumentis \& sacris Christi vtentis quoque accedere opportet, hoc est, indubitatam fidem in Christum \& promissiones eius, quae opus Christi apprehendit, eoque fruitur. Non quod fides aliquid ex se nobis promereatur, vel ad opus meritumque Christi nonnihil ponderis practerea adferat, sed quod opus Christi apprehendat." 
communion with Christ to all the faithlul. ${ }^{112}$

However, Bucer's phrase opus sumens alerts us to the fundamental tension between the two accounts of the opus operatum. Gropper held that in the Supper Christ had offered his body and blood to the Father and given them to the apostles. Bucer held that he had given them to the apostles, but had not offered them to the Father.

Giting Luke 22:19 and John 17, Gropper insisted that Christ's thanksgiving and intercession had made the Supper an offering and sacrifice. ${ }^{113} \mathrm{He}$ insisted that the fathers had distinguished between the offering and distribution/consumption of the Eucharist. ${ }^{14}$ Citing Ps.-Cyprian, De coena domini, he also argued that, when made with faith and devotion, the priest's intercession in the Eucharist was more effective than elsewhere. ${ }^{113}$ It might appear from this that Gropper regarded the church's intercession as part of the cucharistic opus operatum, but, as we have seen, he denied this. The church's thanksgiving etc. was the opus operans. Hence it sccms that Gropper understood the Last Supper as a priestly action by which Christ made his body and blood present as offered for the world by his thanksgiving etc. By consecrating, the church's ministcr made the same offered body and blood present. $\mathrm{B}_{\mathrm{y}}$ thankful commemoration and intercession the entire church applied the benefits of the present victim to itself. By receiving the sacrament individuals applied communion with Christ to themselves.

According to Bucer, Christ offered his body and blood to the Father on the cross, but not in the Supper. In the Supper, he gave them to the apostles as food and drink. Just as one was not baptised for others, one did not receive communion for others. ${ }^{16}$ He granted, nevertheless, that Jesus had given thanks over bread and a cup, and prayed for the elect. Timothy 2:1-2 also gave a mandate for thanksgiving and intercession in the Supper. ${ }^{117}$ Prayer over bread and wine, as well as invocation could be called "offering" not just because the fathers of the church had done so,

112 Ibid., 315, "Fides [sic: i.e. fidei] enim non modo applicationem agnoscunt, vbi quilibet sibi per propriam fidem redemptionem ac meritum Christi apprehendit \& applicat: verum etiam applicationem Sacerdotis, qui redemptionem \& communionem Christi omuibus fidelibus pes verbum \& sacramenta applicat \& tradit."

${ }^{113}$ Antididagma, $108 \mathrm{~b}$.

${ }^{11+}$ Ibid. Citing Augustine, De Trinitate 3.10 (PL 42:881) "in altari offertur et datur, et peracta pietatis celebrationem sumitur"; Conncil of Neocaesarea can. 13 (Crabbe 1:223) "Preshyteri... offerre non possunt, nec panem sanctificatum dare, calicem porrigere."

115 Antididagma, 109b-110a. Presumably PL 189:1641-1650, "in huins [i.e, sacramenti] praesentia non supervacue mendicant lachtimae" quoted in the Worms-Regensburg Book (BDS 9.1:465, 1. 10-11).

${ }_{116}$ Constans defensio, 315 \& 340 , "Constat Dominum de sacramentis corporis \& sanguinis sui non dixisse, offerte ea Patri, sed accipite, comedite, bibite, \& Hoc facite in commemorationem mean. In quibus verbis nullum habemus praeceptum de oblatione corporis \& sanguinis Christi."

:17 Ibid., 313, 315. 
but because such actions met the criteria for "offering" under the law of Moses. ${ }^{\text {IIB }}$ No-one, wrote Bucer, denied that these elements should also be included in the Supper. ${ }^{19}$

Again, Gropper and Bucer agreed that, in its own right, application pro aliis was simply intercession. Both agreed, as well that true and efficacious intercession was made through, with and in Christ. Hc was the High Priest of the spiritual sacrifices of his members. As noted earlier, Bucer was even ready to admit Cyprian's claim that the institution of the Eucharist was in some sense priestly. However, for Gropper both the anabatic and catabatic dimensions of Christ's priesthood were "represented" in the consecration. For Bucer only the catabatic dimension (i.c. from God to humanity) was represented.

Despite this, Bucer called the Antididagma's description of the church as the opus operans of the sacrifice a "remarkable confession of the truth." $120 \mathrm{He}$ praised their claim that it was ultimately faith, rather than the deputation of a priest, which made one a beneficiary of the sacrifice. ${ }^{121}$ To the claim that incercession offered in the Eucharist was more effective, he replied that his adversaries knew that the real source of this sentenia was not Cyprian. He granted, however, that the more solid the faith with which intercession was offered, the more effective the prayer. ${ }^{122}$

As, elsewhere, his principal objection was to the shortfall between his adversaries' teaching and their practice. Even if the scholastics had never taught that the Mass availed ex opere operato sine bono motu utentis, it was clear, he wrote, that a magical conception of the opus operatum had "put down deep roots among the majority of people." Moreover, the theological obfuscation used by his adversaries to defend the status quo, only served to confirm this error. ${ }^{123}$ When did the partisans of the Mass ever instruct the people about the true meaning of the opus operatum? In most countries, he wrote, preaching had all but ceased outside Advent and Quadragesima, and the people were not instructed to turn their attention and the desire of their hearts to what the priest was doing. Instead they believed that:

${ }^{118}$ Ibid., 315, "... oblatio dici potest, iuxta consuetudinem legis mosaicae: \& sic omnes antiqui patres S. Coenam oblationem dixerunt."

${ }^{119}$ Jhid.

${ }^{120}$ Ibic., 310. Cf. Antididagma, $109 \mathrm{~b}$ quoting Innocent III, De sacm altaris mysterio 5.2 (PL 217:888b) "...quod populus agit voto, sacerdotes peragunt ministerio [PL:mysterio]..."

${ }_{121}$ Antididagma 109b, does allow that the sacrifice night benefit the evil but, "non pro sacrificantis, sed pro Dei bona voluntate" Presumably by obtaining the grace of repentance for them. See above, ch. 3, p. 48.

122 Constans defensio, 317.

${ }^{123} \mathrm{Tbid}, 317$, "... negari non potest errorem istum in nimis magna hominum parte sat [sic] altas radices egisse, quas nec Aduersarij tentant, quin potius omnibus ijs, quae ad conservationem istius abominationis Saciunt, fuco patrocinantur." 
by his own intention and direction in the secret Mass the priest applies the sacrifice of Christ and his own work of saying the Mass to whomsoever he wishes, and from this anyone at all may secure the greatest possible grace and blessing for body and soul from the Lord... In the meanwhile the people are taught either nothing or a very little about how at Mass they must apply the sacrifice of Christ and the prayer of the faithful to themselves through faith. ${ }^{24}$

Only if Christians spoke clearly, using the words of Scripture, would the people understand that true application meant:

that the church of Christ... prays and gives thanks, through the priest and with the priest, first for other people, and then so that the priest may stir, prepare and sanctify the people, by means of Christian teaching and exhortation, to beg and pray that in the sacraments they will receive the sacrifice of our Lord Jesus Christ, the grace of the new and everlasting testament, the remission of sins and every kind of blessing from the bounty of God, and through their own faith apply these to themselves. ${ }^{125}$

Ifere, again, the praycr of the church's minister was not simply intercession, but also a form of preaching (praedicatio) by which those present were stirred up to appropriate the benefits of Christ's sacrifice to themsclves through reception of the sacrament. In De wera et falsa Bucer quoted from Cyprian's Epistola 58, "the victim which provides an example of courage and faith must bc immolated to [or for] those of the brothers who are present." Bucer understood this to mean that the example of Christ must be preached to the clergy in order to stir them to courageous confession of the faith, and even martyrdom. ${ }^{26}$

${ }^{124}$ Thid., 312, "... quod sacerdos intentione ac deputatione sua in secreta missa, sacrificium Christi, \& proprium suum opus missandi cui velit applicet, quo vuusquisque gratiam \& henedictionem a Domino pro corpore \& anima quam optime consequatur... Interim populus aut nilhil admodum parum docetur, quomodo sacrificium Christi, fideliumque orationem apud missam sibiipsis per propriam fidcm applicare clebeat, \& quod ea sine fide neno cuiquam mortalium applicare possit, quod neque adhuc apud Aduersarios docetur."

125 Ibid., "...praesens Ecclesia Christi per sacerdotem \& cum sacerdote, pro aliis quoctue hominibus orat, \& gratias agit: vtque saccrios per Christianam doctrinam \& adhortationem homines excitet, praeparet, \& sanctificet, quo propria fide sacrificium Domini nostri Iesu Christi, gratiam noui \& acterni Testamenti, remissionem peccatorum, \& omnimodam benedictionsm. bonitatis diuinae ex animo per Christum Dominum nostrum petant \& orent, irl sacramentis percipiant, vereque sibiipsis applicent."

${ }^{126}$ De vera, 187, "Primum gratias cgerunt Deo patri \& Christo filio pro dono tam praechro confessionis, quod eis Dominus contulerat: Dcindc orauerunt atque petierunt a Patre per Christum Dominum, ut ipse Dominus qui perfectus est \& perficicns glorian confessionis qua dignatus illos etat, eis custodiret, \& perficieret."Cf. Cyprian Eptstola 58 "ad Lucium" (l'L 3:1006-1007; alsp "Epistola 61" (CCEL 3:697-698)), "...uictima quae fraternitati pracbet cxcmplum et uirtutis et fidei praesentibus deber fratribus immolari." The marginal notc hore reads "Vide, inmolari pro praedicari." Thus Cyprian supports Bucer's reading of Augustine Enarratio in Psalnum 75. See above, p. 199. 


\subsubsection{The Offering of 'Thanksgiving and Praise}

\subsubsection{Offering for the Living}

Although Bucer and Gropper debated application under the heading of the church's self-offering, the beneficiaries of this application were discussed under the heading of the offering of thanksgiving and praise. The rationale for this division (at least on Gropper's part) seems to have its origit in Gropper's distinction between: (1) the res oblata in which the corpus Cbristi mysticum is already perfectly united and all the benefits won by Christ are available (i.e. "applied" to his body), and (2) the efficacy of this oblatio which is limited by the faith of the individual and still imperfect members of the body.

Thanksgiving, according to the Antididagma involved the recollection that God is the author of all good things. Since God caused his sun to rise and rain to fall on the good and bad alike (Matt 5:45), the church prayed for all conditions of humanity (1 Tim 2:1-2), both just and unjust, present and absent. ${ }^{127}$ Bucer would contest none of this and, as we have already noted, he regarded such intercession as integral to the institution of the Supper. However, Gropper found fault with the eucharistic prayer in the Bedenken because it failed to mention the pope and other leaders of church. Here he cited Ephesians 6:[18-20], 2 Thessalonians 3:[1], and a canon of Pope Pelagius I stating that anyone who did not pray for the apostolic pontiff in the Eucharist was cut off from communion with the whole world. ${ }^{128}$ Bucer replied that although the ancients were accustomed to name those who brought offerings to the Supper, as well as the names of bishops and presbyters, the recitation of particular names was not itself a part of the Supper's institution, and did not occur in the liturgy of the Hurrarchia ecclesiastica. Besides, he continued, it was disingenuous of his adversaries to insist on the necessity of any recitation of names, when the Canon was in an unintelligible language, and could not be heard by anybody. ${ }^{129}$ As to the naming of the pope, Bucer noted that the letters of Cyprian suggested that no-one beyond the bishop was prayed for in that Father's church. The Greeks still prayed for nowone beyond the Archbishop. ${ }^{130}$

\subsubsection{Offering for the Dead}

There continued to be a measure of agreement between the two parties on

${ }^{127}$ Antididagma, 92b. Citing Chrysostom, Homilia 26 (or 25) in Afatthaeum (PG 57:331); Tertullian, Apologia 39 (PL 1:532).

${ }^{128}$ Antididatgma. 93a. See. Pelagius I, Epistola ad episcopos 7usciate (PL 69:398C).

${ }^{129}$ Constans defensio, 287.

${ }^{130}$ Ibid., 288. See Cyprian, Epistolate 9, 11, 66 (PL 4:258, n. 2 "offertur nomine eorum", ibid.; 263; 411); Liturgy of John Chrysostom (Brightman, 388) 
the nature of the memorial of the saints (i.e the commemoration - though not the direct invocation - of those who already enjoyed the beatific vision) in the Eucharist. In Constans defensio, Bucer cited the same patristic sententiae as the Antididagma (Hierarchia ecclesiastica "in the explanation of the Eucharist," Augustine, De civitate Dei 8.27, 22.10 and Contra Faustum 20.21) and did not contest Gropper's interpretation of these. Both agreed that the memorial of the saints provoked the faithful to imitation, testificd to the church's belief that the saints were alive in Christ and with the church, not only in memory, but in the unity of the body of Christ. ${ }^{131}$

Regarding Augustine's claim that the church also sought to be "associated with the merits" of the saints and aided by their prayers, Bucer referred his readers to his discussion of the invocation of the saints elsewhere in Constans defensio. ${ }^{132}$ This followed a line of argument similar to that which we have already noted in the Consilizm theologicum, but now with explicit qualifications. It was certain, he wrote, that the saints prayed for us in heaven as they had on earth, but it was not clear whether in heaven they prayed for certain individuals such as those who honoured their memories, or whether they prayed for all in general. ${ }^{133} \mathrm{I}-\mathrm{Ie}$ now described the "reward" (merces) of the Worms-Regensbarg Book as preferable to "merit" in describing the benefits which God bestows on the obedience and good works of his saints. The Gcrman word for "merit," Verdienst, suggested the proportionality and equality of the exchange. The patristic merimm, he wrote,

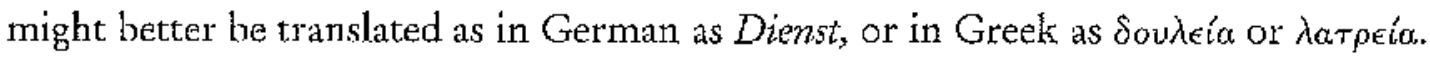
This emphasised that the merits of the saints were the gifts of God: i.e worship of God and good works. Hence, in Contra Fanstum 20.21, "associated with their merits" meant to be "helped by their prayers." 134 Whatever the case, when the Scripture spoke of God being swayed through the intercession of the living saints, the cmphasis was on God's fidelicy to his promises rather than the saints' obedience. Gropper had quoted Augustine's comments on Exodus 32:13-14, (cum merita nostra

${ }^{131}$ Antididagma, 94b; Constans defensio 288-289. Both cite Augustine De civitate Dei 8.27, 22.10 (PL 41:255, 772); Contra Fatstum 20.21 (PL 42:384); The "explanation of the Eucharist" (both are similarly vague) is presumably De bierarchia ecclesiastica 3.9 (PG 3:464). This mentions only the commendation of the saints' example to the faithful. In De vera, 189, Bucer also cites Cyprian, Epistola 34.3 (PL 4:331) ("39.3" in CCEL) and Epiphanins, Adversus batereses 3.1 (heresy 74) (PG 42:513) to the same end: that to offer for the saints is to give thanks for their witness and commend their example.

${ }^{132}$ Constinns defensio, 288.

${ }^{133}$ Ibid., 143, 150-153.

${ }^{134}$ Ibid., 142, "[Meritum] apud eos [i.e. patres] non tam late patet, quam apud nos (Verdienen und verdienst) quae rocabula portionem quandam \& acqualitatem in se habent... Melius... reddi possit per uocabulum (Dienst) quam (Verdienst) ${ }^{n}$; ibid., 149, "(Merita) apud Patres in genere rithil aliud significare quam cultum Dei \& bona opera... Populum christianum memorias martyrum... celcbrarc... vt meritis eorum, hoc est, douleiais e latreiais consocietur..." 
nos gravant.. relevari posse eorum meritis, quos diligit). ${ }^{135}$ Bucer replied

When he [i.e. Moses] invoked the memory of the ancient patriarchs and friends of God, saying: Remember Abrabam, Isaac and Israel your servants, he did not add, "who were so obedient to you, and scrved you with such love," but: to whon you swore by your own self, saying, I shall multiply your descendants like stars of the beaven etc; a promise which the Lord most certainly made to them out of nothing but his grace." $" 136$

Gropper had also reasserted the point, made in the Encbiridion, that the Canon never addressed the saints directly, but always God Father, "through Christ our Lord." He noted that in its second memorial of the saints - the Nobis Quoque the Canon sought a share in their fellowship, addressing God "not as a recknner of merit, but as the dispenser of pardon." ${ }^{137}$ Herc, however, Gropper clarified what had not been clear in the Worms-Regensburg Book. The communion of the saints meant not only a share in what had been given to the church by God in Christ, but in all the things which the saints had possessed or received through God's mercy. ${ }^{138}$ Like the Enchiridion, the Antididagma did not elaborate any further. ${ }^{139}$ However, Bucer belicved that he saw again the spectre of supererogatory works and indulgences. He insisted that, although the faithful had communion in Christ with all the saints from the foundation of the world, it could not be concluded from this that their "merits" might be imputed to us. God repaid each according to his or her own works (Eph 6:8). ${ }^{140}$

Again, while Bucer conceded that commemoration of the saints might be legitimate, he denied that it was integral to the Supper's institution. He would heed patristic references to "offering" for the martyrs only when his adversaries began to celebrate the Supper in the way the fathers described it. Because a superstitious faith in the saints had prejudiced faith in Christ among the people, it was no longer expedient to mention their names in the Supper. God required that the rites of the

${ }_{135}$ Antididagma, 34b; Qutastiones in beptateuchum 2.149 (PL 34:646). See above, ch. 3, p. 54.

${ }^{136}$ Consians defensio, 141, "Cumque memoriam veterum quoque Patrum, \& amicorm Dei troduceret [sic], dicens, Recordare Abraham Isadc E Israd serworum suom, [Exod 32:13] non subiicit, Que tam obedientes tibi fuerunt, tibique tam diligenter sertiertunt, sed: Quibus iurasti per temetipsum, dicens, Multiplicabo semen vestrum, sicut stellas coeli, \&c. Quam promissionen Dominus procul dubio ex mera gratia illis fecit.:

${ }^{11 \%}$ Antididagma, $95 \mathrm{~b}$; C.. Canon missac, Nobis quoque.

138 Antididagma 32a, "Omnes quoque uere credentes, \& in cadcm communione permanentes, habent participationem now eorum tantun, quae Deus nobis per Christum donauit \& tradidit. Verumetiam eorum omnium bonorum, quac sancti Dei quotquot fucrunt ab initio mundi, ad sıos usque unquam habuernnt, aut per misericordiann cius acceperunt."

${ }^{19}$ As in Enchividion, 158b-160b, Anitdidagma, 127a fil, referred only to the cancellation of temporal punishment through satisfactiones canonicae sen disciplinares.

${ }^{140}$ Constans defensio, $146-147$. 
church be preserved only, "where godliness is effectively promoted through them. Whatever stands in the way of this or has a harmful effect on it should, in so far as it is possible, be done away with." ${ }^{141}$

With respect to the memoria defunctorum in Christo (i.e. Lhose not specifically recognised as saints) Gropper cited a passage from Augustine's In Evangelium Iobannis 84.1 which, he alleged, distinguished between "offering" for the saints "offering" for the dead. In the first case, Gropper claimed, the church expressed its confidence that the saints had gone to their final reward and sought the assistance of their intercession. In the second casc, the church offered prayer for those it knew to have died in the faith, but about whose final purification it was uncertain. Gropper went on to argue that this second category embraced the souls awaiting libcration from Purgatory. ${ }^{142}$

In both Constans defensio and De vera et falsa, Bucer countered with an argument similar to that already noted in Melanchthon's Apologid: that in most of the patristic witnesses (including the Liturgy of Basil) offering was made without distinction for, "those who rest in Christ: forefathers, fathers, patriarchs, prophets... and every spirit which has departed in faith." ${ }^{143}$ Bucer knew that the Eastern churches did not believe in Purgatory, and suggested that if they ever had, it was because the Turkish threat to Constantinople had forced them to accede to Western pressure at the Council of Florence in $1439 .{ }^{144}$ While he did not specifically challenge the distinction in Augustine's In Iohannem, he claimed that there was ultimately no difference between the state of the two kinds of dead for whom the church prayed. In the case of the "saints" (defuncti sancti), the church gave thanks for their witness and commended thcir example. In the case of those he called the defuncti laici, fideles wulgares or fideles non martyres the church gave thanks for them, sought rest for them, and celcbratcd the blessed resurrection. ${ }^{245}$

Regarding prayer for the defincti laici, Bucer claimed that the essence of the practice was found in the Hierarchia ecclesiastica 7 . The priest, he wrote, gave thanks for the forgiveness of sins granted the dead and praised God for destroying the

${ }^{141}$ Ibid., 289, “... vt per cos pietas efficuciter prouehatur: quicquid vero ei obstare 8 officere valet, quantum quidem fieri potest, e medio tollatur." Sainls' days were not, however, abolished (see instructions for preaching at the "sainis' memorials," BDS 11.1:374-375).

${ }^{142}$ Antididagma, 103aj Cf. Augustine, In Evangelium Iobannis 84.1 (PL 35:1847), "Idco quippe ad ipsam mensam non sic eos [i.e. martyres] commemoramus, quemadmodum alios qui in pace requiescunt, ut etian pro eis oremus, sed magis ut ipsi pro nobis, ut corum vestigiis adhaeramus."

${ }^{143}$ De vera, 190-191; Liturgy of Saint Basil, Anaphora (Brightman, 406).

${ }^{144}$ De vera, 236 "Quod \& Concilium Florentinum fecit, in quo haec quaestio tractata est, cum Graecis, qui tandem spe anxiliotum contra Turcas, quae a Latinis petebant, esse aliquod Purgatorium, tenuiter sane, ut acta testantur, admiserunt, sicut \& de Primatu Papae supra omnes ccclesias." Cf. Rlorilegizm (BOL 3:30). See Latantur coeli (DS 691-694) (Crabbe 3 not available).

${ }^{145}$ De vera, 191-192; Constans defensio, 288. 
dominion of $\sin$ in them and bringing them before his just judgement. ${ }^{146} \Lambda$ ccording to Bucer the same belief was evident in the funeral orations and "epitaphs" of Gregory Nazianzen, Basil, Jcrome and A mbrose. These fathers recognised the sins of the dead, but gave thanks to God for having takcn them to their rest through his grace and the merits of Christ. They confessed their belief in the communion which the dead and those who mourn them have in Christ. $\Lambda$ s the church did not hesitate to pray for forgiveness for the living or to absolve them, so these fathers had not doubted that God forgave the sins of the faithful departed and gave them etcrnal life. $^{147}$

Bucer believed that Ambrose was the final witness to a previously unbroken consensus of the fathers that, "the one who has not received forgiveness in this life will not reach the next one." "The Antididagma had cited a number of Ambrosian sententiae which referred to the offering of oblationes on behalf of the dead. Bucer was able to show that in each case, the soul in question was also assumed to be in glory. ${ }^{\text {it? }}$.

Here Bucer's use of the fathers was at its most nuanced. I le did not attempt a wholesale appropriation of the fathers cited by his opponents. Indeed, he argued that certain opinions of Gregory, Bernard, [Ps.-] John Damascene, and more particularly, Augustine and John Chrysoston should not be heeded in the present circumstances. They had no firm foundation in Scripture nor in the practice of the apostolic church. Yet he attempted at the same time to offer a sympathetic account of the of the dcvelopment of the practice of "offering" for the cead and of the doctrine of Purgatory in the patristic church.

${ }^{146}$ Constans defensio 290; De vera 197. Citing Ps.-Dionysius, De bierarchia ectlesiastica 7 (esp. 7.3 (PG 3:556ff). Bucer, however, ignores two passages quoted in Antididayma 103b-104a: De bierarcbia ecclesiastica 7.6.64 (PG 3:561) re. the effectiveness of the "praycrs of the rightcous" and "the saints" in this context, and ibid. 7.6.56-60 which claims the scriptural warrant of Samuel's prayers for Saul (possibly referring to 2 Esdras 7:108).

${ }^{1 \cdot 7}$ Bucer cites specifically and discusses only Ambrose (see discussion below). The passage From Gregory Nazianzen is probably Oratio 7 in laudem Caesarii fratris, (PG 35:755-788, csp. 774775) cited in Antididagma 103b. Gropper (ibid.) also cites "Gregory of Nyssa," (Locus nusgtatm occurit in editis, according to PG 95:253, n. 11) and Ps.-Athanasius, Qutestiones ad Antiochum Ducem 34 ( $P G$ 28:617) re. benefit of prayers and good works for the dead. All probably via [Ps.JDamascene, De bis qui in fide dormierstnt (PG 95:247-278, esp. 263 and 265, and 11. 4).

i48 Ambrose, De bono mortis 2.5 (PL 14:569) "...Qui enim hic non acceperit remissionem peccatorum, illic non erit." See also Cyprian, Ad Demetrianum 25 (PL 4:582) quoted in both Constans defensio, 294 and De vora, 208-209: "Quando istinc excessum fuerit, nullus iam poenitentiae locus est, rullus satisfactionis effectus..."

${ }^{149}$ Antididagma, 105b. See Ambrose, Epistola 39 (PL 16:1146), “...haec autem ad tempus quidem erepta nobis, meliorem illic vitan exigat? Ttaque non tam deplorarudam, quan prosequendam orationibus reor; nec noestificandam lachrymis tuis, sed magis oblationibus animam eius Domino commendendam arbitror." Constans defensio, 292 and De vera, 197 cmphasisc "meliorem vitam illic exigat." Constans defensio, 292-293; De verd, 193, 196 also cite or quotc Ambrose, De obitu Valentiniani consolatio 77 (PL 16:1442) \& De obitu Theodosii (PL 16:1461-1462). 
Gropper had appealed to the commonplace 2 Maccabees 12:[44-45] as proof of the antiquity of the practice. ${ }^{159} \mathrm{He}$ had also produced Ps.-Dionysius Hierarchia ecclesiastica "3.7," (i.e. 3.9), Epiphanius Contra Haereses 3.1 (heresy 74) John Chrysostom, Homily 32 on Mattbere, Ps. John Chrysostom, "Homily 69 to the people of Antioch" and [Ps.]-John Damascenc, Sermo de bis qui in fide dormierunt in support of the claim that prayer and sacrifice for the dead had their origin in the apostolic church and with the Lord himself. ${ }^{151}$

In Constans defensio, at least, Bucer did nor contest the canonicity of 2 Maccabees, nor did he deny the possibility that prayer for the dead might have been practiced in the apostolic church. ${ }^{152}$ Instead, he contested the assertions of the Antididagma on the following two grounds: the first was the paucity of references to this practice in Scripture; the second was the principle, enunciatcd earlier in Constans defensio, that not all the traditions and practices of the apostolic church were binding on subsequent generations. If prayer for the dcad had been central to apostolic preaching, Bucer wrote, Paul would have enjoined it in 1 Thessalonians 4:13ff where he bade his readers not to grieve for those who have fallen asleep in Christ. While the Old Testament mentioned sacrifices for almost every other eventuality, sacrifice for the sins of the dead was mentioned only in 2 Maccabees 12. Thus, Bucer thought it most likely that sacrifice for the dead was a practice which the Jews had acquired through their contact with the Hellenistic world. In commending such an offering, Judas Maccabaeus might have been attempting to hallow a semi-pagan practice so as to stir his men to faith in the resurrection of the

${ }^{150}$ Antididagma, 105b; for Gropper also proof Purgatory. De vera, 215, however, rejects the "paralogism" that because the church offers prayers and sacrifices for the dead, it follows that this is done in order to obtain fuller remission of their sins or a mitigation of the punishment due to them. Thus the question of prayer for the dead is separated from the question of Purgatory. For Bucer's discussion of the scriptural basis of the doctrine of Purgatory specifically, see below.

${ }^{151}$ Antididatgma, 103b-105b. See Ps.-Dionysius, De bierarchia ecclesidstica 3.9 (PG 3:464); Epiphanius Contra baereses 3.1 (heresy 74) (PG 42:503-516); Chrysostom, Homilia 32 in Mauthatum (PG 57:375); Homilit 69 ad Populum Antiochenum "Quod peccatores lugendi sunt viventes \& mortui, \& quod multum defunctis prosunt elecrnosynae, \& officia pro eis exhibita," (Divi Ioannis Chrysostomi opera, 5 v. (Paris; Clatude Chevallon, 1536) 5:336; not located in PG, but cf. PG 59:348; $60 ; 169 ; 61: 360)$. Antididagma, 105a notes debt to Oecolampadius's 1520 translation of this sermon Quantum defunctis prosint viuentium bona opera, sermo Toannis Damasceni lohanne Oecolampadio interprete, (Augusburg, 1520) and notes that Oecolampadius translated the work, "cumn nondum ab Ecclesia Catholica plane deficisset." Consians defensio 301 acknowledges that he, too, is citing, Oecolampadio interprete. On this edition, see Backus, "What Prayers for the Dead in the Tridentine Period? [Pseudo-] John of Damascus, 'De his qui in fide dormierunt' and its 'Protestant' tranlsation by Johannes Oecolampadius," Zwingliana 19.2 (1993):13-24.

${ }^{152}$ In De vera, 228 he questions its status, citing Augustine, De doctrina christiana 2.8 (PL 34:41); \& Canones Apostolorum, c.84 (Crabhe 1:26); Council of Laodicea, c.59 (Crabbe 1:380); Euscbius, Fcclesiastical Fistory "6.18" [i.e. 6.16 re. Origen's /lexapld] (PG 20:554); However he then continuss, "Scd fac librum istum secundum Machabcorum esse Canonicum, tamen author clare admodum ipse hoc exposuit, nec se preces \& sacrificia pro mortuis alia de causa laudasse..." Latomus, Defensio (CCath 8:59), is likewise reluctant to declare on its canonical status. 
dead. The practice might have been tolerated by the apostles for the same reason. However, Bucer described this conjecture as "barely probable"153

Whatever the casc, it was clear that:

the churches of Christ have not only the power but also the mandate either to observe or omit whatever was not handed down by the Lord or by the apostles as something which pertains to the salvation of Christians of all times. ${ }^{154}$

Prayer for the dead was to be regarded as a practice which belonged in this category. While acknowledging that Epiphanius had described prayer for the dead as a tradition handed on by Christ, he noted that the same father had described fasting on Tuesday as a precept of the apostles. ${ }^{155}$ The adversaries must, therefore, regard those who ignored the Tuesday fast as infidels, or admit that prayer for the dead did not belong to that category of traditions which were absolutely necessary for edification in the faith. ${ }^{156}$

Bucer did acknowledge that patristic references to "offerings" and the performance of good works for the dead were widespread. However he appealed to the connection between prayers of thanksgiving and acts of charity. He claimed that the funeral rite described in De bierarchia ecclesiastica 7 emphasised forgiveness of sins and the hope of the resurrection and surmised that the oblationes were made in thanksgiving for this. ${ }^{157}$ Hence the fathers had called funcrals "offerings" because they included almsgiving for the support of the poor and the public ministry. ${ }^{158}$

In De vera et falsa Bucer engaged in a detailed examination of Epiphanius's refutation of the heretic Aërius in his Adversus baereses 3.1. In response to the Antididagma's accusation of "Aerianism" (i.c. the rejection of prayer for the dead), Bucer distinguished between the heretical contention that prayers and good works for the dead were no use at all, and the denial that these prayers and good wortss

${ }^{153}$ Constans defensio, 304-306; See also De vera, 228-229.

${ }^{154}$ Constans defentio, 302, "Quicquid non a Domino vel ab Apostolis eius traditunn est, vt quod ad salutem omnium Christianorum, atque omne tempore conducat, id vel obsertandi vel intcrmittendi non modo potestatem verum etiam mandatum habent Christianae Ecclesiae..."

${ }^{155}$ Epiphanius, Contrabaereses 3.1 (heresy 74) (PG 42:512).

${ }^{195}$ Comslaris defensio, 306-307.

${ }^{157}$ De vera, 203. Cf. De hierarchia ecclesiastica 7 (PG 3:551f). Here he ignores the fact that the funcral rite also includes prayers for the forgiveness of the sins of the deceased (ibid. 7.6-7 (PG 3:559-56.3) however this prohlem has becn "neturalised" by his observations in De vera, 200. See below, p. 219.

${ }^{158}$ De vera, 184-185, 200. Buccr argues (ibid. 204) that such funcrals werc not celcbrated in conjunction with the Lord's Supper. The two, he alleges, were only gradually associated in the Western Church "...quod spem resurrectionis in hac per praedicationem mortis Christi, \& comrnunicationem corporis \& sanguinis Christi maxime confirmatur, studiumque nouae uitae praecipue excitatur." Ignored by Antididagma 103b, which appropriates the non-eucharistic funeral service of De bierarchia ecclesiastica 7 to defend the Roman Canon. 
could in some way alleviate the suffering of the souls in Purgatory. Epiphanius, he argued, had defended prayer for the dead only in relation to the former: i.e. because of its role in the church's confession of faith in the forgiveness of sins and the resurrection of the dead. ${ }^{159}$ In both De vera et falsa and Constans defensio Bucer attempted to demonstrate that although the Bedenken omitted prayer for the faithful departed, its funeral service contained the essentials of patristic practice: i.e. stirring the people to repentance and mortification; confirming their faith in the resurrection; and confirming their hope in the communion which the faithful departed have in Christ. ${ }^{100}$

Bucer recognised that Aërius had also objected that if prayers and good works were held to bring relief to the dead, people would neglect godliness and righteousness in this life. These objections were almost exactly Bucer's. He denied, however, that this aspect of Aërius's teaching was essential to his heresy. ${ }^{161} \mathrm{He}$ believed that, like Augustine, Epiphanius had probably believed that prayer for the dead brought relief, "only to those who had lived in such a way that they would deserve to benefit from such assistance." If so, he would have been right to reject Aërius' claim that prayer for the dead encouraged complacency in this life. This, however, did not amount to a binding endorsement of the notion that such good works were of benefit to souls in Purgatory. ${ }^{162}$

The Antididagma had quoted a passage from Epiphanius which claimed that prayers for the faithful departed were, "of benefit, even if they do not excise their whole guilt (totam culpam)." 16.3 Bucer, who seems to have had access to the recently published Greek text of Epiphanius' Panarion, noted that the translation of tota

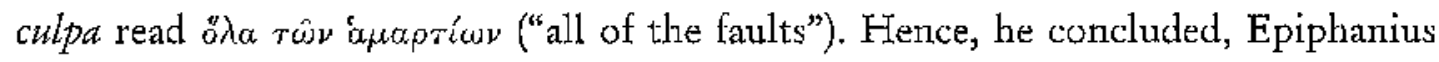
must mean that prayers for the dead did not cancel any of blame of those who die without faith. He also noted, quite correctly, that the scholastics had not spoken of prayer removing the guilt the dead. Rather they held that it removed the temporal punishment due to sin after the guilt and eternal purishment of death had been removed through the merits of Christ. ${ }^{164}$

${ }^{159}$ Constans defensio, 298; De vera, 225.

${ }^{1160}$ Constans defensio, 303; De vera, 251ff. See 13DS 11.1:375-390.

${ }^{161}$ See e.g. De vera 243 , "Nundinatio purgatorij extinxit poenitentiam \& fidem uivorum."

${ }_{162} \mathrm{Ibid}$., 224, "[Aerius] reijcibat, quod defunctis preces licclesiae nihil prodessent, \& si illas prodesse defuncris quis diceret, ex eo consecutum iri, ut homines dum hic uiuerent, pietatem \& iusticiam negligerent... Haec igitur cum Aerius obijceret, si sensisset Epiphanius mortuos, precibus uitorum releuari, ut id putauit D. Augustinus, oportuisset eum etiam idem respondere, quod D. Augustinus respondit, nimirum preces \& sacrificia Ecclesiae defunctis quidem prodesse, sed ijs tamen qui cum uiuerent, ut hae sibi postea possent prodesse meruissent..." [emph. mine]

${ }_{163}$ Antididagma 104a, "Prosunt auten \& preces quae pro ipsis fitnl, etiam si totam culpam non abscindunt" Citing Ephiphanius, Contra baereses 3.1.74 (PG 42:514).

${ }^{164}$ See PG 42:513. De vera, 222-223 assumes that baimatia is interchangeable with culpa used in the scholastic technical scnse: "Aduersarij nostri Colonienses... inferre conantur, Ergo partem 
Nevertheless, in an aside in De vera et falsa, Bucer did admit the possibility of a sort of causal (though not a sequential) relationship between prayer for the dead and the full remission of sins which it is hoped the faithful departed now enjoy. Here Bucer cited the reversed temporal scqucnce by which the conversion of Paul was related to the Baptism which he subsequently underwent. Prayer for the dcad could be compared to the sacrametits as "seals" of the wrork of God which had preceded them. ${ }^{165}$

Thus Bucer avoided the accusation of "Aerianism." In the end it is not clear what Bucer thought Aërius's heresy actually was. At worst, his fault was that he had denied the cxpediency of a non-essential tradition which, in its own time, served to confirm something essential: namely, faith in the forgiveness of sins and the resurrection of the dead.

Epiphanius, however, had not condemned scepticism on the subject of Purgatory, nor denial of its existence. As we have already noted, Bucer believed that Purgatory had crept into the teaching of the church after the time of Ambrose. Even then, he believed that sound apostolic doctrine had survived largely without confusion up to the time of Bermard of Clairvaux. "In Constans defensio a story in [Ps.] John Dannascene's Sermo de bis qui in fide dormikrunt about Gregory freeing Trajan's spirit from Hell by his prayer was produced as an example the "trifling figments" of popular piety. ${ }^{167}$ However, Bucer offered Bernard's Sermo 26 in Cantica canticorum on the death of his brother Gerhard, and Scmo in transitu $S$. Malacbiae episcopi as proof of Bernard's belief that eternal bliss or damnation followed death immediately. ${ }^{168}$ Bucer conceded that Bernard had referred to sins

aliquam culparum abscindi his Ecclesiae officijs. Vorum id ne Epiphanius subijcit, nes scholastici hoc recipiunt. Nam \& hi culpam omnem uiuis remitti agnoscunte, ctiamsi figmenturn ilhd de expiatione poenarum in purgatorio amplexi sint" See also Constans defensio, 298, "Porro quod dicil orationem. istam non omnem culpam resecare fieri potest, vt in eo sensu dixcrit, quod infidelitas peccatum non resecetur. "Quicunque enim sinc fide in Christum cx has vita migrant, ij iam iudicati sunt." According to PG 41:iv, the first Greck imprint, from an ms. given to Melanchrhon by J. Lang, was Tou hagiou Epiphaniou... kata batreseon ogdoekonta... Panarion, ed. J. Oporinus (Basel: J. Hervagius, 1544); first Latin imptint: D. Epiphaniz... contra octaginta baereses ophus...transl. J. Cornarius (Basel: $\mathbb{R}$ Winter, 1543).

${ }^{165}$ De vera, 200-201. He also cites the discussion of circumcision in Romans 4.

${ }^{166}$ De verat, 230-232 also cites the liturgy for the dead: "Et hinc certe factum est, ut in illis qunque lectionibus \& cantionibus, quas tui Latome uocant Vigilias defunctorum, eo, quod olim noctu $\mathrm{km}$ as funera uigilabatur, recitari \& decantari solebant, nullum insit uerbun de purgatorio uestro, sed omnia moneant de noxa peccatorum, de uera poenitentia, de metu \& horrore iudicij diuini, de mortc \& resurectione Christi, quibus credentibus Christo, peccata, mors, \& condem natio sublata sunt." Cl. Pontificale sectindum ritum sacrosanctae Romanae eccleside... (Lyons, [s.n.], 1542), 230ab, "De vesperis \& matutinis pro defunctis..."

167 Constaris defensio, 301. See [Ps.]-Damascene, De bis qui in fude dormienunt (PG 95:261264).

${ }^{168}$ Constans defensio, 3CO. See Sermones in Cantica 26 (PL 183:903-912) and Sermones in transitu S. Malacbiate episcopi (PL 183:481-490). No specific refs. given. Both Sermones in transitu servc Bucer's case. 
forgiven in the age to come (Matt 12:32). He claimed, however, that here Bernard was writing not according to his own judgement and opinion, but that of common people. ${ }^{169}$ Bucer did not cite his source herc, but it was probably Bernard's Sermo 66 in Cantica Canticorum, cited in the Antididagma. If it was this passage, then Bucer's conclusions about Bernard and the opinion of the common people seem to have been rather hasty. ${ }^{170}$ Certainly Bernard did not re-appear in De vera et falsa.

De vera et falsa included a lengthy discussion of the scriptural texts used to support Purgatory in Catholic apologetic." ${ }^{171}$ Bucer argued that the "fire" in 1 Corinthians 3:11-15 referred to the testing of doctrine by adversity during this life and on the day of judgement. Here he cired Jerome's and Chrysostom's commentaries on this passage. ${ }^{172}$

He dismissed the exegesis of Matthew 12:32 in Augustine's De civitate Dei 21.24. It was, he wrote, a deceptive fantasy to conclude that therc wcre sins which would be forgiven in a future age. ${ }^{173}$ Even if Augustine were correct, Luke 23:43 (re. the good thief) showed that Christ could grant remission of sins and entry into Paradise "this day" without the need for the torments of Purgatory. ${ }^{174}$

Bucer noted that his adversaries citcd Matthew 5:26 (non exies inde, donec reddas novissimum quadrantem) as proof that there would eventually be a release for the faithful departed who had "paid the last penny" of their temporal punishment. He replied with a curious allusion to Matthew 1:25, (non cognoscebat eam donec peperit filium sunm primogenitum) According the adversaries, souls would be not be released from Purgatory "until" they had paid their last penny. According to this passage, Joseph did not "know" Mary until (donec) she bore Jesus. According to the logic of the adversaries, this must mean that Mary bore further children after Jesus. ${ }^{175}$ The latter seems to have been as unthinkable for Bucer as the former.

Having demonstrated the frailty of the scriptural case, Bucer did not tarry long with Chrysostom's ruminations on the fate of the dead before the general resurrection or Augustine's "more tolerable damnation" and not very good or bad. ${ }^{176}$ Thesc passages wcre juxtaposed with those (noted earlier) which referred to

160 Constans defensio, 300.

${ }^{170}$ Antididagma 1C6a. See Sermones in Cantita 66.10-11 (PL 183:1099-1100) directed against the "Manichae" who deny marriagc, baptism of infants, Purgatory", prayers for the dead and the invocation of the saints.

${ }^{171}$ De vera, $232-241$.

${ }^{172}$ De vera, 233-234. Cl. Jerome, Expositio in Epistolam I ad Corintbios (PL 30:755-756); Chrysostom, Homilia 9 in 1 Epistolam ad Corinthios (PG 61:79).

${ }^{173}$ De vera, 238; See PL 41;738. Constans defensio, 300 notes that "Gregory" uses this and 1 Cor 3 to arguc for a purifying fire after denth. See possibly, Gregory Dialogi 4.39 (PL 77:393-396).

${ }^{174}$ De vera $238-239$.

${ }^{175}$ Ibid., 240-241; Constans defensio 299.

176 Constans defensio, 298ff; De vera 206ff. Citing Chrysostom, "Sermo 69 to the Antiochenes" (see above, p. 216); Homilia 7 in 1 Epistolam ad Thessalonicenses [2-3] (PL 62:436-440) 
the immediacy of the eternal punishment or reward. While Bucer never described Augustine's views as erroneous, he concluded in De vera et falsa that Augustine had spoken inconsiderate. The uncertainty of Augustine's opinions was suggested by Father's description of the purgatorial fire as "not unbelievable." Invoking Tertullian's De praescriptionibus, as well as several of the well-known sententiae in which Augustine had submitted his writing to the judgement of canonical Scripture, Bucer claimed that what had always been uncertain in the church should never be taught as its doctrine:

However great their holiness, however forcelully they teach it, we should not hold as fixed nor regard as true anything the holy fathers wrote in their books after the confirmation of the canon if we do not take what they hand down to us as thoroughly proven to be true by canonical Scriptures, or probable reasoning. Indeed, with due regard to the honour owed to men of such greatness, we may legitimately mistrust and even reject any judgement or understanding of theirs which with God's assistance we find to differ from the truth as it has been understood by others or by us." 177

\subsection{The Status of the Roman Canon}

Most of what Bucer had to say about the substance of the prayers of the Roman Canon has been discussed already. However, we have still to address his judgement on the Canon's suitability for use in the I,ord's Supper. The German version of the Antididagma (the Gegenberichtung) included a German transiation of the Canon. ${ }^{178}$ The reason for this was explained even in Billick's Latin translation. Gropper accused Luther's Vom Greuel der Stillmesse (1525) of having translated the

(against the theory of metempsychosis; cited only in Constans defensio); Augustine, De octo Dutcitit qudestionibus 2 (PL 40:157-158); De cura pro mortwis gerenda 1.2 (PL 40:593) (cited only in De vera); Enchiridion 67-68 (PL 40:263-265); De file et operibus 15-16 (PL 40:212-217); De civitate Dei 21.26 (PL41:743-746).

${ }^{177}$ De vera, 211, "Non debere cos firmun tenere, nec uerum putaxe, in libris S. Patrum, quotquot post confirmatum Canonens scripsertunt, quantalibet sanctitate, quantaue doctrina illic polleant, si non id quod tradunt uerun intellexerimus, hoc est, comprobatum per scripturas canonicas, aut probabiles rationes, immo etiam licere nobis, salua honorificentia quae tantis debetur hominibus, aliquod in scriptis eortm improbare, atque respuere si forte intteniamus, ditino adiutorio, quod aliter sexserint quam ueritas habet, uel ab alijs intellecta, uel a nobis." Citing Tertullian, De praescriptionibus (no exact reference given; possibly 38 (PI, 2:62); Augustine, De Trinitate 3, "Proemium" (PL 42:869); Augustine, Epistola 82.1 (PI. 33:277); De batptismo contra Donatistas 2.3 (PI, 43:1280); Fpistola [148] "ad Fortunatianum" 3.[15] (PI, 33:627-628); These final three are from the Decretum Gratiani 1, dist. 9, c. 3, 7-8, 10 (Friedberg 1:17-18) See above ch. 2, p. 15.

${ }^{178}$ Lipgens, 146. 
Canon, "treacherously and unfaithfully, as is the wont of heretics.". ${ }^{179}$ Not only had Luther held the Canon up to ridicule with his "blasphomies," but, he had made it available to the judgement and derision of everyone, the good and the bad, the simple, the ignorant, and those scarcely capable of understanding the mysteries. "The Canon was now discussed in town squares and bath-houses $1^{180}$ Gropper had thus sought to remedy Luther's translation with one of his own. He begged the reader to rreat this material with the reverence duc to it. ${ }^{\text {It1 }}$

Unsurprisingly, the Antididagma claimed that the Canon contained nothing which had not been obscrved at the time of the apostles. This much, it argued, was evident from a comparison with the prayer described in De hierarchia ecclesiastica 3 and the "Greek Canon." It was perhaps this claim that drove Bucer to draw on these sources so heavily. Although Gropper did not suggest that the Roman Canon had bcen in use since the time of the apostles, he described it as a prayer of great antiquity. Here he appealed to a letter of Gregory the Great to John Bishop of Syracuse which:

...compares the Canon with the Lord's Prayer in this way, "it was the custom of the apostles to consecrate the sacrifice offered by means of that prayer alone [i.e. the oratio dominica] and it seemed most inopportune to me that we should say a prayer, which a scholar had composed, over the offering, and not recite that tradition, which our Redeemer composed, over his body and blood." ${ }^{182}$

In citing this passage, Gropper's interest lay with the credentials of the scholar (scholasticus). The Greeks had Liturgies attributed to John Chrysostom and Basil. Gropper seems to have wanted to find a distinguished author for the Roman Canon. Scholasticus, he argued, was not someone's proper name. It was the

${ }^{179}$ WA $18: 24-36$. According to Franz, 632 the first vernacular translation of the Mass in Germany was published in 1480 but was quickly withdrawn. The first authorised translation was published in 1530.

:80 Antidiagma, 315a, "... tremenda illa \& adotanda potius quam curiose inuestiganda mysteria nephatio \& scelecato ausu publicat, uertit Canonem Missae in linguam 'l'eutonicam, idque haereticonsm more, perfide \& infideliter: Deinde etian conmentario blasphemo simul ac scurrili ita defoedat, conspurcat, \& lubridio adficit, ut nihil possit contemptius, abiectiusque uideri: atcluc hos: ornatum modo, omtaibus publicat, bonis $8 x$ malis, simplicibus, rudibus, sceleratis ctiam $8 x$ mysteriorum minime capacibus, iudicandum $\&$ deridendum."

${ }^{181}$ Ibid., $115 \mathrm{~b}$.

${ }^{182}$ Ibid., $11 \mathrm{lb}$, "confert ibiden Canonem ipsum cum Oratione Dominica, hoc nodo: Mos... apostolorum fuit, ut ad ipsam solummodo orationem, oblationis bostiam consecrarent, \& ualde mibi inconueniens uisum est, ut precem quam Scholasticus composturat, stiper oblationem diceremus, E ipsam traditionem, quam Redemptor noster composuit, super eiws corpus $\&$ sanguinem non diceremus $E$ c." Cf. PL 77:956-958. 
honorific title of a man learned and experienced in the affairs of the church. ${ }^{183}$ The title indicated Gregory's esteem for the composcr. In support of this Gropper cited Augustine's reference to scholastici in De catechizandis rudibus 9 and Beatus Rhenanus's notes on Origen in his edition of Eusebius' Historia ecclesiastica. ${ }^{184}$ Thus Gregory's letter had not indicated contempt for the Canon or its author. Rather, he was arguing that the Oratio dominica (which Gropper took to be the Pater noster) should not be omitted at the end of the Canon. ${ }^{185}$

In addition to this, the Antididagma made the familiar Catholic appeal to Augustine's comments on 1 Timothy 2:1 (obsecrationes, orationes, interpellationes at gratiarum actiones) in Epistold 149 to Paulinus. ${ }^{186}$ Here the passage was cited not so much to suggest that the structure of the Canon had a Pauline provenance, as to show that a prayer of similar shape had been used by Augustine. Lest this sequence be taken to endorse those Reformed liturgies in which thanksgiving followed the communion rather than preceding it, Gropper cited John Chrysostom's Homily 83 in Matbeum which spoke of two thanksgivings in the Last Supper: the prayer which Jesus had spoken over the cup before giving it to his disciples and the singing of psalms afterwards. ${ }^{187}$

In Constans defensio Bucer dismissed the notion that Gregory's use of scbolasticus indicated esteem for the Canon's putative author. He notcd that Beatus Rhenanus had observed that in schools attached to the churches of Alexandria scholasticus "perhaps" signified a teacher of long-standing. 'I'his, however, said nothing about the value attached to the title among the ancients. De catechizandis rudibus 9 did not serve the casc of the adversaries either. Scholasticus was found only in the excerpt of this passage in the Decretum Gratiani. The adversarics had clearly not referred to the original text. ${ }^{188}$ Besides, the "teachers" to which the original text referred were pagans approaching the church for Baptism rather than teachers of divinity. Nevertheless, Bucer wrote, even if one were to grant that the esteemed scholasticus had existed, that he had composed a prayer used by Gregory, and that

${ }^{183}$ Antididagma, 111b, "Porro scitur quid patres nomine Scholastici olim significauerint: Non utique uirum aliquem cui hoc nomen esset proprium: sed peritum, egregie doctum, \& in rebus Ecclesiasticis exercitatun uirum."

${ }^{164}$ PL 40:320. In fact, "quidam de scholis"; Beatus Rhenanus, Antores bistoriae ecclesiasticae... (Basel: Froben, 1528), 132, "Praeficitur apud Alcxandriam scholae ecclesiasticas, hoc est, magister Catechumenonum" re. Eusebius, Mistoriat ecclesiasticd 6.3, in which attention is drawn to the consistency of Origen's life with his doctrine.

${ }^{185}$ Antididatgma, $111 \mathrm{~b}$.

${ }^{186}$ PL 33:635-637.

${ }^{187}$ Antididagma 111b. Sce Augustinc, Efristola 149.2.16 "ad Paulinum" (PI 33:637) "Quibus peractis, ct participato tanto Sacramento, gratiarum actio cuncta concludit..."; Chrysostom, Homilia 82 (or 83) in Mattbielim (1PG 58:740) re. Malt 26:30.

${ }^{188}$ Decretum Graliani 1, dist. 38, c. 9 (Friedberg 1:143), "Sedulo monendi sunt scholastici..."; For both Beatus and Augustine, see above p. 223. 
this prayer was the same as the present Canon, it could most certainly not be proven that he had been a teacher of the ancient church. No other ancient writer mentioned him. The adversaries' appeal to Gregory's letter, showed at the very most that the Roman Canon had been composed by a learned individual some time prior to or during the pontificate of Grcgory. ${ }^{185}$

Although the Antididagma had elsewhere pointed to similarities between the Roman Canon and the cucharistic prayer in Ambrose's De sacramentis 4, Bucer refused to accept this as evidence of the Canon's antiquity. "Who is there," he asked, "among the truly learned who believes that thesc books are Ambrose's?"190 There was, he claimed, every cvidence that the Liturgies attributed to John Chrysostom and Basil were themselves products of a process of change, accretion and admixture, and bore little resemblance to what the two fathers in question had written about the Holy Supper. ${ }^{191}$

In Constans defensio, Bucer proceeded to examine the Canon, prayer by prayer, in order to demonstrate its "manifest ungodliness:"

If we wished to go through it part by part, we should find in abundance horrible perversions, contempt and dishonour for the majesty of God, as well as the baneful seduction of the simple people. ${ }^{192}$

Despite these remarks, Buccr's objection was, again, not to the Canon itself, but to the way in which it was used in the contemporary church. Bucer argued that in its original context the Canon had been "proclamation" (pracdicatio) prior to the distribution of the sacrament. It was to such preaching or proclamation that Augustinc had referred in the Epistola 149 to Paulinus. ${ }^{193}$ Thus his rejection of the Canon in Constans defensio is consistent with his vindication of what he believed to have been its true sense in $D e$ vera et falsa.

There was, however, such a shortfall between the practice of the contemporary church and the original intention of the Canon's composers, that he believed the prayer must be modified or abandoned. It was recited quietly and in a

${ }^{189}$ Constans defensio, 328.

${ }^{190}$ Tbid., 335. Bucer also belicyed that Erasmus doubred the authenticity of De sacramentis. See his remarks tccorded in the Codex Musculus, Fraenkel, "Les protestants," 103, n. 22 where he claims, incorrectly, that Erasmus regarded it as inauthentic.

${ }^{131}$ Constans defensio, 328-329.

192 Ibid., 330, "Iam si per singulas cius partes transire voluerimus, rutsus horrendas peruersiones, contemptum \& ignominiam diuinae Maiestatis, perniciosam item simplicium scductionem abunde reperimus."

${ }_{133}$ Ibid., 328. Cf. Augustine, Epistola 149.2.16 "ad Paulinum" (PL 33:637) “... quo Sacrancnto praedicatur nustrum illud votum maximum, qto nos vovimus in Christo esse mansuros, utique in compage corporis Christi." Here Bucer also cites "Chrysostom," probably Homilia 25 (or 26) in Matthaeum (PG 57:331) quoted in Antididagma, 912. 
language which the people did not understand. This encouraged them to put their faith in the mutterings and crossings of the priest rather than in Christ. It also subverted the rule of Paul (1 Cor 14:26, 40) that all praycr must be both intelligible and edifying. The Canon, in other words, no longer fulfilled its function as proclamation.

Even if the Canon were now translated and said aloud, the people would not understand it properly. Again, Bucer did not deny that the Canon might once have becn used in and edifying and suitable way - nor, indeed, that it might be explained again in the same way. However, in Constans defensio, he considered the explanations offered by the Antididagma and exclaimed:

such glosses are elegant indeed, if only they were also understood and set before the people in this way, but what is the number of priests and Mass-peddlers who understands these words in such a sense, let alone explaining them and passing them on to to the church of Christ?

Instead the present performance of the Canon, with its gestures, language, silence, and sacramental minimalism, was calculated to lead the people and the vast majority of the priests into godless superstition. Instead of parroting the fathers or trying to hide the mysteries of Christ from the faithful with "prolix commentaries and glosses," the adversaries should attempt to imitate the fathers by doing as they did: i,e speaking openly, intelligibly and simply, and observing tcaching of Christ and the apostles. ${ }^{195}$

Here Bucer appealed to the "forms" (rather than the words) of two patristic accounts of the Lord's Supper: De bierarcbia ecclesiastica 3 and Chrysostom's Homilia 18 in 2 Epistolam ad Corintbos. ${ }^{176}$ The Antididagma had done no more than allege similarities between the eucharistic liturgy of Ps-Dionysius and that of the Roman ritc. Bucer, however, presented a summary of the liturgy similar to that which had appeared in Jacques Lefcyvre's scholia to Traversari's Latin translation of De hierarchia ecclesiastica. ${ }^{197}$ As we noted earlier, this table had been reproduced by Eck in order to demonstrate the apostolic provenance of the Roman rite. ${ }^{198}$ Bucer

19. Constans defensio, 334, "Tales glossae elegantes quidem sunt, si modo etiarn intelligerentur, \& ita populo proponentur: Quantus vero sacerdotun \& missatorum aumenus sist, qui ipsi haec verba tali senst inteiligant, taceo Ecclesiae Christi \& exponant?"

${ }^{195}$ Constans defensio 335, 337 "Quid opus est fidelibus mysteria Christi tam obscuris \& non intellectis verbis abscondere, sepelire, ac deinde prolixis commentariis ac glossis rursus entere 8 in lucem proferre?... Annon debenus totum Euangthum, omnia mysteria Christi \& salutis nostrae fidelibus eius quans apertissime $8 x$ simplicissime proponere?"

${ }^{195}$ De bierarcbia ecclesiastica 3.2 (PG 3:425-428); Chrysostom, Homilia 18 in 2 Epistolam ad Corinthios (PG 61:527).

${ }^{197}$ Constans defensio, 338.

${ }^{198}$ See above ch. 3, p. 50. 
attempted to demonstrate that the Ps.-Dionysian liturgy corresponded better to the new Cologne Order. It was celebrated in an intelligible language to edify the faith of the people. They responded to the prayer of the pricst. They offered their gifts to the poor. At least some of them received the sacrament. One Mass was celebrated at a time. Buccr urged his readers to compare this "form" with that in the new liturgy. He admitted that the new Order included no iticense, kiss of peace or commcmoration of the apostles and martyrs. However, the proper "ancient" signification of the first two was not understood by anyone, let alone the adversaries, and so they could legitimatcly be dropped. Provision had been made for the commemoration of apostles and martyrs "elsewhere" in the Bedenken (i.e. in the provisions made for the celcbration of the saints' days). ${ }^{159}$ Bucer also quoted the account of the liturgy in Chrysostom's Homilia 18 in Epistolam 2 ad Corinthos, almost in its entirety and compared it with the shape of the Cologne order. ${ }^{250}$ The same form, he claimed, had also been used by Cyprian, Jerome, Augustine, and Gregory. He claimed that the third and seventh Councils of Carthage and the third Toletan council had sanctioned a variety of eucharistic prayers provided that they had been composed by "the more prudent bishops" and had nothing in them which was contrary to the faith. ${ }^{201}$ This was no more than the Bedenken had done.

199 Constans defensio, 340

$20 x$ Ibid., 339; PG 61:527.

2งt Constans dejensio, 337. Carthage 3, c.23 (Mansi 3:884) is repeated at Carthage 7 (Mansi 4:435). Bucer incorrectly interprets "mensis" in Toletan 3, c.7 as referring to the Eucbarist. In fact "solent crebro mensis otiosae fabulae interponi" refers to reading at meals hosted by the bishop. 


\section{CONCLUSION}

\subsection{Bucer's use of the Fathers}

In Chapter Four, I noted the model of neutralisation and appropriation as a wray of describing the Reformers' use of the fathers. There is, however, a question which this model leaves begging: to what are the fathers appropriated? The immediate answer is scriptural doctrine, but this leads us to a further question: what is scriptural doctrine for the Reformer in question? If Scripture is assumed to have provided a static and exhaustive blucprint for the doctrine and practice of the church, then patristic witnesses are little more than trophics hung around an already pre-determined system. They have little to contribute to that system except by way of confirmation - and then somewhat unreliably. The same can be said of Catholic apology. Fifteen-hundred years of tradition had to be stretched or squeezed onto a Procrustean bed of the ecclesiastical and theological status quo. Theories of doctrinal development were still four centuries in the offing.

Elements of a thcory of development were, however, evident in the doctrinal hierarchy which Erasmus proposed in Ratio verae theologiae and elsewhere. The church's doctrinal system had its origin and point of fixity in Christ and his simple teaching. The rest was an attempt to articulate what it meant to follow Christ, "with a pure heart, a good conscience and unfcigned faith." The diversity of the Word's andience and of the situations in which the church found had forced apostolic teaching towards ever greater complexity. While there were elements of the church's doctrinal structure which remained static, there were other elements which the church (though not individuals) might change to meet the requirements of different times and circumstances. The eucharistic liturgy was one such element.

Even in the early period of his career as a reformet, Bucer proposed a similar distinction betwecn the principal articles of faith (the Hauptstuck) and their actualisation in the life of the individual believer and the chtrch. As long as the church remaincd founded on faith in Christ and love of neighbour, it continued to be the church, no matter how much it erred in other respects. Although the reform programme in Grand und Ursacb sought to return the liturgical norms of Scripture, the apostolic church served less as a model of perfection than of the attempt to turn orthodoxy in to orthopraxis: doctrina vera into confessio vera, as Bucer would later put it. In the 1530s Bucer began to acknowledge that this had led the apostles and their successors to institute various traditions for which they had no express scriptural or dominical mandate. However, to acknowledge the legitimacy of these traditions was not to afford them all the same authority. IIence in the same period 
Bucer appealed to Augustine's Epistola 54 to Januarius in distinguishing between traditions with vis ad pietatem (such as infant baptism) from tcmporary expedients (the veiling of women) and erroneous traditions (the Mass).

Because of his distinction botween the principal articles of faith and their actualisation, Bucer was able to appropriate the fathers in a relatively nuanced and sympathetic way. He was able to appeal to a consensus patrum on the principal articles of Christian doctrine without claiming absolute uniformity in 1500 years of Christian praxis. The fact that an institution, rite or even a form of language was presently associated with ungodliness did not necessarily mean that it had been that way in the past. Nor did the fact that a practice had been associated with godliness in the past mean that the church was bound to preserve it in the present.

This brings us to a further aspect of Bucer's use of the fathers: his attempt to reverse gradually the gradual historical process by which the liturgical norms of the apostolic church had become tainted with error and impiety. The liturgical reforms in Strasbourg during the 1520 s saw the elimination of rites and ceremonies which Bucer regarded as obstacles to worship in spirit and in truth. Even here, however, he was preparcd to use or tolerate things he considered less perfect (e.g. the elevation) in order to draw the weak to things more perfect. In the 1530s Bucer became convinced that there were traditionalists, anchored in the principal articles of Christian doctrine but nevertheless "addicted to ceremonies," who could be drawn to things more perfect by those very ceremonies. Here Paul's dealings with Judaising Christians set an example of what Bucer would call epieikeit: the attempt to apply laws with a view to the intention of the law-giver (here edification in faith and love) rather than in accordance with their letter. Sign and signified in Christian worship were not so necessarily connected that non-scriptural rites presently conducive to error could not be turned to edifying ends. Indeed the gradual passage from the imperfect and changing world to the perfect and spiritual underlay Bucer's understanding of the entire economy of "ceremonics" including the sacraments.

\subsection{Bucer and the Eucharistic Sacrifice}

As we noted at the outset, Francis Clark has presented Reformation hostility towards the Mass as in attack on an "incarnational" theology of sacramental mediation and co-operation. He defincs this theology as follows:

through a channel of created causes, God reaches down to men, as it were, to bring them salvation, and then implants in them a deiform principle, sanctifying grace, which begins and energises their ascent towards ultimate union with himself. In this economy of mediation through the church, the Mass is the principal instrument of Christ's saving action. Through its Eucharistic counterpart, the sacrifice of the 
cross is made available for all men in succeeding ages. In this great "work" mortal priests are vicars of the immortal IFigh Priest."

He attempts to demonstrate that the Reformers' attack on the Mass was not the result of distortions in late mediaeval theology or abuses but of their hostility towards such a view of the church, the sacraments and their ministers. Is this contention borne out by an examination of Bucer's views on eucharistic sacrifice?

A complete answer to this question would involve a broader discussion of Bucer's views on the nature of justification, the church, the ministry and, indeed, of the Eucharist, than has been possible here. Nevertheless, I believe that within the parameters of this study it is possible to show that Clark's account is too tidy to describe the relationship between the views of Bucer and his principal opponents with any accuracy.

Bucer and Gropper set out to resolve the question left hanging at the end of the Diet of Augsburg in 1530: in the Eucharist, what is the relationship between Christ's merit and work and the church's merit and work; between the chturch's impcrfect self-offering and the perfect and complete sacrifice of Christ? Both ment agreed that the Eucharist was a sacramental means by which the mystery of the body of Christ was brought to complction in those incorporated into it. The sacrificed body and blood of Christ were "represented" through word, sacrament and the ministry of the church. Those who faithfully commemorated Christ's sacrificial offering of his body and blood on the cross recognised that their spiritual sacrifices of praise were offered through, with and in Christ their high priest. As Augustine put it, they saw the mystery of themselves "on the altar" and received the body and blood of Christ in order that their "Amen" might be true. The transformation of the faithful into the one body of Christ was thus associated with and caused by a sacramental transformation of the elements of bread and wine through the almighty words of Christ and the operation of the Holy Spirit.

Bucer rejected the claim that Christ had offered his body and blood to God the Father in the Supper either with, in or under the elements of bread and wine. To this extent, Bucer's understanding of the Worms-Regensburg formula involved a Melanchthonian distinction between sacrament and sacrifice. The observance of the Lord's institution involved an objective "representation" of the sacrificed body and blood of Christ really and substantially (though with the caveat that these words were not to be understood naturaliter, quantative vel localiter but sacramentaliter). T'o the extent that these gifts were received by the faithful, the Eucharist could be said to "contain" the sacrifice of Christ. Here Bucer was prepared to speak of the

${ }^{1}$ Clark, 105-106. 
consecration of the sacrament as opus operatum, and to describe the consecrating minister as acting ex persona Christi.

In addition to this, the faithful offered a sacrifice of thanksgiving, praise, of themselves and of alms for the poor. Here Bucer was prepared to say that the minister offered prayer in the eucharistic celebration ex persona ecclesiae. Bucer would insist, however, that this aspect of the Eucharist could only be called the "sacrifice" of Christ in a figurative sense. The faithful "set" or "represented" Christ before the Father in their prayer by thanking the Father for the salvation won in Christ and offering their intercession through Christ.

Gropper, as we have seen, regarded the consectration as the means by which these two aspects of the Eucharist which we have called catabatic and anabatic, were united ex opere operato by the priest consecrating ex persona Christi. Through the priest observing the dominical institution in accordance with the intention of the church, Christ united the internal self-offering of his members, symbolised in the sacraunental elements, with his own offering to the Father. Through the consecration, the sacrifice of Christ was "applied" to the church. The priest prayed expersona ecclesiae that its fruits might be of benefit to all members of the church still on their way to glory. Bucer seems to have associated "application" ex opere operato with the anabatic movemement of the eucharist: i.e. with a mediate opus performed by priest in accordance with a perverse understanding of the Supper as a mandate to offer the consecrated body and blood of Christ to God the Fiather for the sins of the living and the dead. Gropper also referred to ex opere operantis limitations on the eucharistic sacrifice in connection with the church's oblatio: i.e. the priest's intercession and the devotion or "faith" of the beneficiarics. However it is clear that he regarded the constitutive sacrifice of the Mass - the sacrificed body and blood present on the altar - as no less effective than the offering of Christ on the cross. Gropper's association of "application" ex opere operato with the consecration (i.e. the catabatic movement) seems to have encouraged Bucer to believe that Gropper had abandoned application ex opere operato.

Clark has noted references to the "pleading" of Christ's eternal sacrifice in later Protestant eucharistic theology and liturgy. He argues, however, that this language takes on a different complexion depending on whether or not "real objective presence... in the consecrated elements is admitted or denied." The failure of Gropper and Bucer to agree or even understand each other on this point appears to support Clark's contention. But do these differences support Clark's central thesis: that Reformation opposition to the Mass sprang from a fundamental hostility to any notion of sacramental and ecclesial mediation? 
From the beginning, Bucer's eucharistic doctrine was characterised by its emphasis on the effects of the sacrament: the actualisation of what was commemorated in the life of the individual believer and in the corporate life of the church, both invisible and visible. The faithful who participated in the sacrament carried with them the death of the Lord in order that his life might be visible in their bodies; they lived no longer for themselves but for others; Christ dwelt in them and they in him; they became onc bread, one body with one another and with Christ their head.

For Bucer, the visible corporate life of the church was the arena in which the invisible reality of the mystical body had begun to be actualised visibly. As Hamman has argued, the visible church, its ministry and sacraments were not a priori indispensable for salvation in Bucer's scheme of things. In the second half of the 1520's sacraments were simply visible signs of invisible grace. However, from the early 1530 s Bucer came to regard them as the habitual and normal instruments by which the Holy Spirit was bringing about the first imperfect manifestations of the kingdom. In this respect, Hammann claims, Bucer regarded the visible church as the kingdom's indispcnsable servant. ${ }^{3}$ Bucer did not admit a straight-forward equation between the external fellowship of the baptised and the mystical body of Christ. Those who were not joined to Christ by faith, participated in the Eucharist only sacramentotenus, as Augustine had put it. Howcver, like Melanchthon, Bucer would countenance Catholic language of sacramental transformation and (if compelled to it) "transubstantiation" as long as a line of demarcation was maintained between the inward and outward dimensions of the sacrament: Irenaeus's "heavenly" and "carthly." This was not to say, however, that the earthly could not mediate the heavenly.

Bucer's understanding of this mediation is captured in his quotation from Gelasius I's De duabus naturis. The humanity of Christ had "passed" into his divinity through the operation of the Spirit. The two were now united in the one person without either losing its individual properties. Likewise, through the Spirit, the elements were joined in sacramental union with the substance of Christ's lifegiving flesh without loss or confusion of their own properties. Likewise human nature "passed over" into the life-giving flesh of Christ without its own substance being "emptied out."

Provided that the distinction between the earthly and heavenly dimensions of the rite was respected, then it was possible for Bucer to appropriate a great deal of the traditional vocabulary of eucharistic sacrifice. The therne of Christ's high priesthood was not prominent in Bucer's eucharistic theology. He was,

${ }^{3}$ Hammann, $109-110$. 
nevertheless, prepared to acknowledge with Augustine, that just as Christ's body was present in the midst of his members, so Christ was present in the Eucharist as high priest, presenting the spiritual sacrifices of the faithful to God the Father. Provided that the sacrifice of the Mass was understood as logike latreia Bucer acknowledged that the "Canon of the Greeks" rightly spolse of Christ as "offered and offering" and of the heavenly, and spiritual altar on which the church presentcd its sacrifice to God the Father. It was from this altar, that according to the Roman Canon, the faithful who participated in the sacrament were filled with every heavenly blessing and grace.

It is also clear that Bucer was prepared to recognise a sense in which the very institution of the Eucharist could be described as an offering and an exercise of Christ's pricsthood. We have already noted that Bucer did not share the view of the Wittenberg reformers that sacrament and sacrifice were exclusive categories. Rather he stood with the Swiss Reformers in treating the sacrifice as a sub-specics of sacrament or "ceremony." The Eucharist succeeded the sacrifices of the Old Testament as an outward sign of inward grace and as an outward expression of inward worship. The internal reality which bound the sacraments of the two Testaments together and lent them their efficacy was the sacrificial death of Christ and the participation of the faithful in it. However, the sacraments of the New Testament were more effective than those of the Old. For Gropper this was because they "contain grace." For Bucer it was because they were united with a "fuller" and "more effective" outpouring of the Holy Spirit (and, consequently, less need for ccremonies).

Bucer held that, like the sacrifices of the Old Testament, the eucharistic rite could be cclebrated in an cxternalistic fashion: it could become an idol and an abomination; it could be used to oppress the poor and rupture the bonds of love which it was supposed to confirm. However, like the sacrifices of the Old Testament, the Eucharist could also function as an outward representation of the obedience of faith, of the worshippers' readiness to place their lives and goods at the disposal of God who they acknowledged as their Creator, Redeemer and Sanctifier.

It was in this context that Bucer would appeal to the model of the first-fruits offering of Deuteronomy 26 (via Irenaets' Adversus baereses). Underlying his appeal was his discussion of the exhibitive/representative function of sacrifices in the Romans commentary. Material gifts were collected and presented with thantrsgiving for God's acts in the past, his present kindness, and the hope of his decisive intervention in the coming Messiah. The rite as a whole, prayer and gifts, "represented" both God's acts and the people's tharkssgiving for them. A portion of the gifts was then enjoyed in God's presence by the priests and the people. Another 
portion was set aside for the use of the poor and for the priesthood. According to Bucer, this model explained why Irenaets and Cyprian had described the Supper as the institution of an offering or sacrifice and Christ's actions in the Supper as priestly. Christ had offered thanksgiving to the Father, with word and sacrament he had "represented" the sacrifice of his body and blood to his disciples, and he had commanded them to do the same in memory of him. Bucer regarded the addition of a collection of alms in the Supper as a legitimate unwritten tradition added to the celebration by the apostles. Considered as a total rite, the dominical institution of the Supper embraced both sacrament and sacrifice; God's initiative and his people's grateful response; both catabasis and anabasis.

Morc remarkably, Bucer found this pattern in the shape of the Roman rite so detested by Luther and Zwingli. Bread, wine and alms had been collected during the offertory. These were presented to God the Father with prayct in which the outward elements served as external tokens of the church's internal self offering. A portion of this offered bread and wine was consecrated so that it became an cxternal representation of the fundamental offering of Christ through whom all true worship was made. The faithlul circumstantes were further itcorporated into the mystery of Christ's body by the Holy Spirit opcrating through the word and the outward tokens of Christ's sacrificial death. For this reason, the post-consecratory prayers of the Canon referrcd to the consecrated portion of the offering as "the bread of everlasting life and the cup of eternal salvation." This, in other words, was what they now "represented."

Here Bucer was also prepared to countenance the legitimacy of commemorating those who had died in Christ: both the martyrs, and the rest of the faithful departed. The principal intention of this commemoration was to commend the example of the martyrs to the faithful. Like Melanchthon but unlike Zwingli Bucer allowed that the saints in glory prayed on the church's behalf. Unilike either, he allowed that in this qualified sense the saints could be said to "merit" God's assistance for others: i.e. in so far as God chose to reward their prayers. Prayer for the dead was appropriate in the Eucharist where the faithful contemplated the eternal life won for them by Christ's sacrifice and desired that this same reward might be given to others for whon they prayed. Here Bucer seems to have been unique among the Reformers in comparing prayer for the dead with the sequence of events in Paul's conversion and subsequent baptism. If baptism could be a "seal" of election, prayer for the dead could also be a "seal" of faith in the resurrection.

Bucer, however, believed that patristic liturgical commemoration of the saints and the faithful departed had preceded the development of the doctrine of Purgatory and supererogatory merits. Likewise he believed that the Mass of the 
Roman rite had preceded the development of the papist doctrine of transubstantiation which he placed after the definitive use of transubstantiatis by Lateran IV. In conjunction with these, and other subsequent developments such as infrequent communion and the sacralisation of Latin, a legitimate liturgical tradition with vis ad pietatem had become a tool of Antichrist.

These elements underlay Bucer's policy toward the Mass during the era of the colloquies and the Cologne Reformation. During the 1530s he began to believe that most of the ritual and prayers of the Roman rite could be restored to what he believed had been their original significance. This would have involved elimination or at least reduction of Masses at which no communicants presented themselves, a liturgical collection and presentation of alms together with the bread and wine at the offertory and the use of the vernacular or at least a programme of preaching in which the proper significance of the rite was explained. It is almost certainly the case that Bucer regarded reform of this kind as provisional. However, as we have already noted, he regarded even the purest celebration of the sactaments as a divine accommodation to human weakness. Strict adherence to the simple ceremonial law of the New Testament was the surest way of inculcating the obedience of faith. However, circumstances sometimes meant that one had to do onc's best with the material available and bring as many as possible, step by step, to a fuller perception of the truth. As it was, the refusal of his adversarics to admit even such modest liturgical reforms made the retrieval of the traditional rite impossible. Moreover, relatively fawourable circumstances in Cologne made it possible to reconfigure the traditional liturgy in a way which drew a less anabiguous line between worship in spirit and in truth and the ungodly persuasions of Antichrist.

The eucharistic rapprochement between Bucer and his Catholic adversaries cannot be written off as diplomatic flexiloquentia, nor hailed as a prototypical exercise in ecumenism, nor simply dismissed as a case of misunderstanding. Their discussion and debate between 1539 and 1546 contain all three elements, but the ambiguities and misapprehensions should not blind us to the common ground which renders problematic any attempt to present "Catholic" and "Protestant" as self-contained and mutually contradictory categories. 


\section{BIBLIOGRAPHY}

\subsection{CONTEMPORARY PRINTED SOURCES AND PRIMARY SOURCES IN PRINT}

Altenstaig, Johannes. Lexicon theologicum complectens vocabulorum descriptiones, diffinitiones [sic] \& interprelationes, omnibus sacrae theologiae ac diuini verbi concionatoribus magno vsui futuruma... Antwerp: Peter Beller, 1576.

Ambrose of Milan. Ambroise de Milan, Des sacraments, Des mystères. Edited by $B$. Botte. New ed. Sources chrétiennes, 25bis. Paris, 1961.

Aquinas, Thomas. S. Thomae Aquinatis doctoris angelici Summa lheologiae. Edited by P. Caramello. 4 v. Turia, 1956.

- Summa totius theologiae D. Thomae Aquinatis... cum Commentariis D. Thomae de Vio, Caietani, cardinali Sancti Xysti, quibus accesserunt \& alia, nempe Supplementum tertiae partis... deinde Quotlibeta auctoris, postremo Opuscula omnia eiusdem... 3 v. Lyons: Apud haeredes Iacobi Iuntae, 1558-1580.

Bekenntnisschriften der evangelisch-lutherische Kirche. 8th ed. Göttingen, 1979.

Bessarion. De sacramento eucharistiae et quibus verbis Christi corpus perficiatur. In Kardinal Bessarion als Theologe, Humanist und Staatsmann: Funde und Forscbungen, new ed., L. Mohler, vol. 3:1-69. Aalen, 1967.

Bible. Opus Biblie una cum postiliis... Nicolai de Lyra cumque additionibus per Paulum Burgensem editis, ac replicis magistri Mathie Dorinck. 4 v. Nuremburg, 1478.

Biel, Gabricl. Gabriclis Biel Canonis Misse expositio. Edited by Heiko Oberman \& William J. Courtenay. 4 v. VIEGM, 31-34. Wiesbaden, 1963-1967.

--- Collectoritm circa quattuor libros 'Sententiarum.' Edited by Wilfridus Werbeck and Udo Hofmann. 5 v. Tübingen: Mohr, $197 \overline{5}$.

Bonaventure. Sancti Bondventurae ex Ordine Minortm... Opera. 7 v. in 6. Mainz: sumptibus Antonii Hierati, 1609.

Brightman, F. E. Liturgies Eastern and Western. Oxford, 1896.

Bucer, Martin. Abusuum ecclesiasticonum, et rationis, qua corrigi eos abusus oporteat, indicatio Imperatoriae Maiestai, in comitijs Reguespurgi, postuianti exbibita. Strasbourg: [Wendelin Rihel], 1541.

--- Acta colloquii in comitiis Imperii Ratisponae babiti, boc est articuli de religione conciliati, \& non conciliati omnes... Strasbourg: [Wendelin Rihel], 1541.

--- Constans defensio ex s. scriptura, et vera catholica doctrina, atque observatione universalis christianae ecclesiae deliberationis de christiana reformatione, quam publicavit Hermannus Arcbiep. Coloniensis... Geneva: Ian. Ant. Saracen and Alexander Pernet, 1613 . 
--- Correspondance de Martin Bucer. Edited by J. Rott. Vol. 1-. SMRT, 25-. Leiden, 1979-.

--- De concilio et legitime italicandis conlraversiis religionis, criminum quae in Mart. Bucerum Iob. Cochlaeus... \& quae Ioh. Gropperus... perscripsit, confutatio... Strasbourg: ex officina Knoblochiana per Georgium Machaeropoerum, 1545.

-De vera ecclesiarum in doctrina, ceremoniis, et disciplina reconciliatione $E$ compositione...: responsio ad calumnias Alberti Pighij Campensis... et refutatio suggillationis Eccianae contra Acta Ratisponensia. Strasbourg: [Wendelin Rihel], 1542.

--- De verat et falsa caenac dominicae administratione libri II. Neuburg: Johannes Kilianus, 1546.

--- Defensio adversus Axioma catbolicum, id est criminationem R. P. Roberti Episcopi Abricensis... Strasboug: Mathias Apiarius, 1534.

--- In sacra quatuor eqangelia, Enarrationes perpetuae, secundum \& postremum recognitae. Geneva: Robertus Stephanus, 1553.

--- Metaphrasis et enarratio in Epistoli D. Patuli Apostoli ad Romanos... Basel: apud Petrum Pernan, 1562.

-martin Bucers Deutsche Schriften. Edited by R. Stupperich et al. Vol. 1-. Gütersloh, 1960-

-_- Martini Bucer Opera Latina. Edited by F. Wendel et al. SMRT, 30-. Vol. 1-. Paris, 1954-; Leiden, 1979-

--- Scripta duo adversaria B. Latomi et M. Buceri de dispensatione sacramenti Eucharistiae, invocatione diuorum, coelibatu clericortm... respondetur etiam Pighii, \& Alphonsi atque deputatorum Coloniensium. Strasbourg: Wendelinus Rihelius, 1544.

- S. Psalmorum libri quinque ad Ebraicam veritatem versi, et familiari explanatione elucidati per Aretium. Felinum theologum. Strasbourg: Georgio Vlrichero Andlano, 1529.

Cajetan(Tomasso de Vio). Reverendissimi... Thomae de Vio Caietani Cardinalis... De sacrificio missae aduersus Luteranos... Rome: per Gerardum Bladum Asulanum, 1531.

Calvin, John. Iohannis Calvini opera quae supersunt omnia. Edited by W. Baum, E. Cunitz \&r R. Reuss. CR, 29-87. Brunswick, 1863-1900.

Clichtove, Josse. Antilutherus... Paris: Simon Colineus, 1524.

--- Propugnaculum ecclesiae... Paris: Simon Colinaeus, 1526.

Coena Dominit die Abendmablsliturgie der Reformationskirchen im 16./17. Jahrhuindert. Vol. 1. Edited by I. Pahl. Spicilegium Friburgense, 29. Freiburg, 1983. 
Die Confutatio der Confessio Augustana vom 3. August 1530. Edited by Herbert Immenkotter. CCath, 33. Münster, 1979.

Crabbe, Peter. Concilionm omnium tam generalium quam particulariun ... in tres nunc tomos ob recentem. multorum additionem diuisa. Vol. 1-2. Cologne: Quentcl, 1551.

Denzinger, H. \& A. Schönmetzer, eds. Enchiridion symbolorum, definitionum et declarationum de rebus fidei et morum. 26th ed. Freiburg i. Breisgau, 1976.

Durandus, Gulielmus. Rationale divinorum officionum... Naples, 1859.

Eck, Johannes. Apologia... aduersus mucores $\mathcal{E}$ calumnias Buceri, super actis Comicionm Ratisponae... Cologne: ex officina Melchioris Nouesiani, 1542.

- De sacrificio missae libri tres (1526). Edited by E. Iserloh \& al. Corpus Catholicorum, 36. Münster, 1982.

-n. Enchiridion locorum communium adversus Lutherum et alios bostes ecclesiae (1525-1543). Edited by Pierre Fraenkel. Corpus Catholicorum, 34. Münster, 1979. bucb

Emser, Hieronymus. Scbriften zur Verteidigung der Messe. CCath, 28. Münster, 1959.

Erasmus, Desiderius. Desiderii Erasmi Roterodami opera omnia emendatiora et auctiora... 12 v. Leiden: Van der Aa, 1703-1705.

--- In nowum testamentum., adnotationes Erasmi Roterodami... Basel: Froben, 1519.

Faber, Johannes. Malleus. Cologne: Peter Quentel, 1524.

Fisher, John, R.D.D. Ioannis Fischerii, Roffensis in Anglia Episcopi, Opera. Wirceburgi: apud Georgium Fleischmannum, 1697.

Friedberg, A, ed. Corpus Iuris Canonici. 2nd ed. 2 v. Leipzig, 1879. reprint Graz, 1959.

Gropper, Johannes. Antididagma seu Cbristiance et Catbolica religionis...propugnatio aduersus librum quendam. Louvain: Servatius Zassenus, 1544.

--- Canones concilii prouincialis Coloniensis sub Reuerendiss. in Christo patre ac dno, D. Hermanno S. Colonien. ecclesiae Arcbiepiscopo... quibus adiectum est Encheridion [sic] Christianae institutionis. Cologne \& Leipzig: Nicolas Wolrab, 1538.

--- Johannes Gropper: Briefwechsel. Edited by Reinhard Braunisch. Vol. 1, 15291547. CCath, 32. Münster, 1977.

-.. An die Roensche Keyserliche Maiestat... Warbafftige Antworl vnd gegenberichtung... Vff martini Buceri Freucliche Clage ond angeben wider $j m$ D. Groepper in eynem jüngst ausgangen Trueck bescheben. [Cologne]: Jaspar Gennepaet1s, 1545. 
Henry VII. Assertio septem sacramentorum adversus Martinum Lutherum. Edited by P. Fraenkel. CCath, 43. Münster, 1992.

Irenaeus, Irenée de Lyons, Contre les hérésies. Edited by A. Rousseau. 8 v. Sources chrétiennes, 100. Paris, 1965.

Latomus, Bartholomaeus. Bartbolomäus Latomus: Zwei Streitschriften gegen Martin Bucer (1543-1545). Edited by L. Keil. CCath, 8. Münster, 1924.

--- B. L. adversus Martinum Bucerum, de controuersijs quibusdam ad religionem pertinentibus, altera... defensio Cologne: Mclchior Novesianus, 1545.

--- Refutatio calumiosarum insectationum Martini Buceri, quibus nouissimis libellis editis in Bartholomacum Latomum extra ordinem inuectus est, ipso Latomo authore... Paris: Christianus Wechelus, 1546.

Lefèvre d'Étaples, Jacques. Theologia virificans, cibus solidus: Dionysii Coelestis Hierarchia, Ecclesiastica Hierarcbia. Polycarpi Epistola Vna. Paris: in alma Parisiorum academia ,1515.

Lenz, Max, ed. Briefwechsel Landgrafs Philipp's des Grossmüthigen von Hessen mit Bucer. Publicationen aus den K. Preussischex Staatsarchiven, 5, 28, 47. Leipzig, 1880-1891. reprint, Ösnabruck, 1965.

Liturgy of John Chrysostom. Divina ac Sacra Licurgia Sancti Ioannis Chrysostomi. Interprete Ambrosio Pelargo Niddano. Worms: Sebastian Wagner, 1541.

Luther, Martin. D. Martin Luthers Werke: kritische Gesamiausgabe. 72 v. Weinar, 1883 -

Mansi, J., cd. Sacrorum concilionum nova et amplissima collectio. 53 v. Florence; Paris, 1759-1927.

Melanchthon, Philipp. Opera quae supersunt omnia. Edited by Karl Bretschneider \& H. Bindseil. CR 1-28. Halle, 1834-1860.

Netter, Thomas. Thomae Waldensis Carmelitae Anglici Doctrinale antiquitatum fidei catholicae ecclesicte ad vetera exemplaria recognitum... Edited by $\mathrm{F}$. Blanciotti. 3 v. Venice: Antonio Bassanesio, 1757.

Oecolampadius, Johannes. De genuina verborum boc est corpus meum, iuxta vetustissime authores expositione liber. Strasbourg: Knobloch, 1525.

-..- Ivannis Oecolampadii ad Billibaldum Pyrkaimerum de re eucharistide responsio Zurich: Froschaver, 1526.

Pactzold, A. Die Konfutation des Vierstädtebekenntnisses. Leipzig, 1900.

Pfeilschifter, G, ed. Acta Reformationis Catbolicae ecclesiam Germaniae concernantia saeculi XVI. 6 v. Regensburg, 1959-1974.

Richter, Aemilius L., ed. Die evangelischen Kirchenordnung des secbszebnten Jabrbunderts. Vol, 2. Nieuwrkoop, 1967.

Rhenanus, Beatus, ed. Autores bistoriae ecclesiasticat... Basel: Froben, 1528. 
Schatzgeyer, Kaspar. Kaspar Schatzgeyer OFM: Schriften zur Verteidignung der Messe. CCath, 37. Edited by E. Iserloh \& P. Fabisch. Münster, 1984.

Schieß, T, ed. Briefrechsel der Brïder Ambrosius und Thomas Blaurer 1509-1548. 3 v. Freidburg i. Breisgau, 1908-1912.

Schirrmacher, Friedrich cd. Brief und Acten zu der Geschichte des Religionsgespräches zu Marburg 1529 und des Reichstages zu Augsburg 1530. Gotha, 1876.

Scotus, John Duns. Joannis Duns Scoti doctoris subtilis, ordinis minorum opera omnia. Vol. 16 \& 26. Paris, 1844-1845.

Witzel, Georg. De Eucharistia sacrosanctissima ecclesiae Christi Iesu. Leipzig: Nicholas Wolrab, 1539.

-.- Georgii Wicelii Methodus concordiae ecclesiasticae cum exbortatione ad concilium, iuxta exemplar excussum apud Nicolaum Wolrab 1533... adiectae sunt notae marginales doctrinut, E vita ipsius... per T.I.S. T.P. London: Iohannes Billius, 1625.

-.- Typus ecclesiate prioris: Anzeigung wie die beilige Kyrche Gottes inwendig siben. und mebr bundert jaren nach unsers Hern Auffart gestalt gewesen sey... reichlich gemehret und von newem gedruckt. [s.1.: s.11.], 1541.

Zwingli, Huldreich. Huldraich Zwinglis samtiche Werke. Ed. Emil Egli et al. CR, 88-. Berlin, 1905

\subsection{SECONDARY}

Augustijn, Cornelis. "Bucer und die Religiongespräche von 1540/41." In Marin Bucer and Sixteenth Century Europe, ed. Krieger, vol. 2, 671-680.

--- "Bucer's Ecclesiology in the Colloquies with the Catholics." In Marin Bucer; Reforming Church and Community, ed. Wright, 107-121.

-_._ "Die Religionsgespräche der vierziger Jahre." In Die Religionsgespräcbe der Reformationszeit, ed. G. Müller, 43-53. SVR, 191. Gütersloh, 1980.

-..- "L'Esprit d'Érasme pendant le colloque de Worms (1540)." In Colloquia Erasmiana Turonensia, ed. Jean-Claude Margolin, vol. 1, 381-396. Toronto, 1972.

--- Te Godsdienstgesprekken tussen Rooms-Katholieken en Protestanten van 15.38 tot 1541. Haarlem, 1967.

-n "Strasbourg, Bucer et la politique des colloques." In Strasbourg ax coeur religieux $d u$ xvi siècle, ed. G, Livet et al, 197-206. Grandes publications de la Société Savante d'Alsace et des regions de l'est, 12. Strasbourg, 1977.

Backus, Irena. "Martin Bucer and the Patristic 'Tradition." In Martin Bucer and Sixteenth Century Europe, ed Krieger, vol. 1, 55m69. 
--- "The Early Church in the Renaissancc and Reformation." In Early Christianity: Origins and Evolution to A.D. 600 in Honour of W.I.C. Frend, ed. Ian Hazlett, 291-303. London, 1991.

--- ed. The Reception of the Church Fathers in the West from the Carolingians to the Maurists. 2 w. Leiden, 1997.

--- "Erasmus and the Spirituality of the Early Church." In Erasmus' Vision of the Church, ed. Pabel, 95-114.

--- "Ulrich Zwingli, Martin Bucer and the Church Fathers." In Reception of the Church Fathers, ed. Backus, vol. 2, 627-660.

-_- "What Prayers for the Dead in the Tridentine Period? [Pseudo-] John of Damascus, 'De his qui in fide dormierunt' and its 'Protestant' tranlsation by Johannes Oecolampadius." In Reformiertes Erbe: Festcbrift für Gottfried W. Locher 'zu seinem 80. geburtstag, H. Oberman et al. eds. Zwingliana, 19. 2:1324. Zurich, 1993.

Barkley, J. "Pleading His Eternal Sacrifice in the Reformed Liturgy." In The Sacrifice of Pratse: Studies in the Themzes of Thanksgiving and Redemption in the Central Prayers of the Eucbaristic and Baptismal Liturgies, ed. Bryan D. Spinks, 123-140. Rome, 1981.

Bentley, J. Itumanists and Holy Writ: New Testament Scholarship and the Renaissance. Princeton, 1983.

Bictcnholtz, Peter \& Thomas B. Deutscher, ed. Contemporaries of Erasmus: a Biographical Register of the Renaissance and Reformation. Toronto, 1985-1987.

Bornert, Réné. La réforme protestante du culte à Strasbourg aux xvi siècle (1523-1598): approche sociologique et interprétation théologique. SMRT, 28. Leiden, 1981.

Bosshard, Stefan Niklaus. Zweingli-Erasmus - Cajetan: die Eucharistie als Zeichen der Einbeit. VIEGM, 89. Wiesbaden: Franz Steiner, 1978.

Braunisch, Reinhard. "Die 'Artikell' der 'Warhafftigen Antwort' (1545) des Johannes Gropper: zur Verfasserfrage des Worms-Regensburger Buches (15401541)." In Von Konstanz nach Trient: Beiträge zur Geschichte der Kirche von den Reformkonzilien bis zum 'lridentinum: Festgabe für August Franzen, ed. Remegius Bäumer, 519-545. Munich, 1972.

- Die Theologie der Rechtfertigung im Enchiridion (1538) des Jobannes Gropper: sein krilischer Dialog mil Philipp Melanchthon. Münster, 1974.

-w- "Johannes Gropper zwischen Humanismus und Reformation: zur Bestimmung seines geistigen Standorts bis 1543." Renaissance Quarterly 69 (1974);192-209.

Carr, Donald W. Tyler. The Influence of Patristic Writings on the Ecclesiology of Martin Bucer. Ph.D. diss., Southern Baptist 'l'heological Seminary, 1981. 
Casel, O. "Das Mysteriengedächtnis der Meßliturgic im Lichte der Tradition." Jahrbucb für Liturgiereissenschaft 6 (1926): 113-204.

Chapman, Mark E. "Sacrament and Sacrifice in the Theology of the Mass according to Luther, 1513-1526." One in Cbrist 28, no. 3 (1992):248-266.

Chrisman, M. U. Strasbourg and the Reform: a Study in the Process of Change. Yale Historical Publications, Miscellany 87. New Haven, 1967.

Clark, Francis. Eucharistic Sacrifice and the Reformation. 2d ed. Oxford, 1967.

De Kroon, Marijn. "Bemerkungen Martin Bucers über das Abendnaahl in seinem Psalmenkommentar von 1529." In Bucer und seine Zeit, ed. De Kroon, 88-100.

-.- Bucer und seine Zeit: Forscbungsbeiträge und Bibliograpbie. Edited by M. De Kroon und Friedhelm Krüger. VIEGM, 80. Wiesbaden, 1976.

-... "Bucer und die Kölner Reformation." In Martin Bucer and Sixteenth Century Europe, ed. Krieger, vol. 1, 493-506.

-.- Studien zu Martin Bucers Obrigkeitsverständnis: Evangeliscbe Ethos und politisches Engagement. Gütersloh, 1984.

Dolan, John P. The Influence of Erasmus, Witzel and Cassander in the Church Ordinances and Reform Proposals of the United Ducbees [sic] of Cleve during the Middle Decades of the 16th Century. Reformationsgeschictliche Studien und Texte, Hft. 83. Münster, 1957.

--- "Liturgical Reform among the Irenicists." In Sixteenth Century Essays and Stzulies, ed. C. Myer, vol. 2, 72-94. Saint Louis, 1971.

Eells, Hastings. "The Genesis of Martin Buccr's Doctrine of the Lord's Supper." Princeton Theological Review 23 (1925):213-233.

-..- Martin Bucer. New Haven, 1931.

--- "The Origin of the Regensburg Book." Princeton Theological Review 26 (1928):355-372.

Fraenkel, Pierre. "Beatus Rhenanus, hiscorien de la liturgie," Anntaire des Amis de la. Bibliothèque bumaniste de Séléstat (1985):247-252.

--- "Beatus Rhenanus, Oecolampade, Théodore de Bèze et quelques-uncs de leurs sources anciennes." Bibliotheque d'Humanisme et Renaissance 41, no. 1 (1979):63-81.

--- "Les protestants et le problème de la transubstantiation au Colloque de Ratisbonne: documents et arguments, da 5 au 10 mai 1541." Oecumenica 3 (1968):70-116.

--- Testimonia Patrum: the Function of the Patristic Aryument in the 'theology of Philip Melanchthon. Travaux d'Humanisme ct Rcnaissance, 46. Geneva, 1961.

--- "Zwischen Altkatholizistnus und Caesaropapismus: zu Martin Bucers Materialsammlung über di Rolle des Papsttums in Der alten Kirche." In 
Reformatio ecclesiae: Beiträge zu kircblicben Reformbemübungen von der Alten Kirche bis zur Neuzeit: Festgabe für Erwin Iserloh, cd. Remigius Baümer, 597 613. Paderborn, 1981.

Franz, Adolph. Die Messe im deutschen Mittelalter. Freiburg i. Br., 1902, repr. Darmstadt, 1963.

Grane, Leif, A, Schindler and M. Wriedt, eds. Auctoritas Patrum: Contributions on the Reception of the Cburch Fathers in the Fifteenth and Sixteenth Century. Mainz, 1993.

Greenslade, S. L. The Reformers and the Fathers of the Church: an Inatgural Lecture Delivered before the University of Oxford on 10 May 1960. Oxford, 1960.

Greschat, Martin. Martin Bucer: ein Reformator und seine Zoit (1491-1551). Munich, 1990.

Hall, Basil. "Colloquies between Catholics and Protestants." Chap. in Humanists and Protestants, 1500-1900. Edinburgh, 1990.

Hammann, G. Entre la secte et la cité: le projet d'Église du reformateur Martin Bucer (1491-1551). Geneva, 1984.

Hazlett, W.I.P. The Development of Martin Bucer's Thinking on the Sacrament of the Lord's Supper in its Historical and Theological Context. Dr. theol. diss., University of Münster, 1975.

--- "A Pilot-study of Martin Bucer's telations with France, 1524-1548." In Martin Bucer and Sixteenth Century Europe, ed. Krieger, vol. 2, 512-521.

--- "Zur Auslegung von Johannes 6 bei Bucer während der A bendmahlskontroverse." In Bucer und seine Zeit, ed. De Kroon, 74-87.

Hendrix, Scott, H. "Deparentifying the Fathers: the Reformers and Patristic Authority." In Auctoritas Patrum, ed. Grane, 55-68.

Higman, Francis, "Bucer et les Nicodemites." In Martin Bucer and Sixteenth Century Europe, ed. Krieger, vol. 2, 645-658.

Honée, E. Der Libell des Hiieronymus Vebus zum Augsburger Reichstag, 1530; Untersuchung und Texte zur katbolischen Concordia-Politik. RST, 125. Münster, 1988.

Iserioh, Erwin. Die Eucharistie in der Darstellung des Iobannes Eck. RSt', 73-74. Münster, 1950.

-- Der Kampf um die Messe in den ersten Jahren der Auseinandersetzung mit Luther. Katholisches Leben und Kampfen im Zeitaltcr der Glaubensspaltung, 10. Münster, 1952.

-..- ed. Katholische Theologen der Reformationszeit. Vol. 1-5. Münster, 1975-

--- "Das Tridentiner Messopferdekret in seinem Bezeihungen zu der Kontroverstheologie der Zeit." In Il Concilio di Trento e la Riforma cattolica: 
Atti del Convegno Storico Internazionale, Trento 2-6 Settembre, vol. 2, 409-412. Rome, 1965.

--- "Der Wert der Messe in der Discussion der Theologen vom Mittelalter bis zum 16. Jahrhundert." ZkTh 83 (1961): 44-79.

Iserloh, Erwin \& Vilmos Vatja. "The Sacraments: Baptism and the Lord's Supper." 'I'ransl. by D. Beekman. In Confessing on Faitb: a Joint Commentary on the Augsburg Confession by Lutheran and Catbolic Theologians, ed. G. Forell \& J. McCue, 202-233. Minneapolis, 1982.

Janse, Wim. Albert Hardenberg als Theologe: Profil eines Bucer-Scbülers. SMRT, 57. Leiden, 1994.

Jedin, Hubert. A History of the Council of Trent. Translated by Ernest Graf. Vol. 1. London, 1957.

--- "Kirchengeschichtliches in der älteren Kontroverstheologie." In R. Bäumer, ed., Reformatio Ecclesiat: Beiträge zu kirchlichen Reformbemühungen von der alten Kirche bis zur Nenzeit: Festgabe für Erwin Iserloh, 273-280. Paderborn, 1980.

Jungmann, Joseph. The Mass of the Roman Rite: its Origins and Development. Transl. by F. Brunner. 2 v. New York, 1951.

Kaufmann, Thomas. Die Abendmablstbeologic der Straßburger Reformatoren bis 1528, Beiträge zur historischen 'l'heologie, 81. Tübingen, 1992.

-- "Streittheologie und Friedensdiplonatie: die Rolle Martin Bucers im Frühen Abendmahlsstreit." In Martin Bucer and Sixteenth Century Europe, ed. Krieger, vol. 1, 238-256.

Keen, R. "The Fathers in the Counter Reformation: Theology in the pre-Tridentine Period." In Reception of the Church Fatbers, ed. Backus, vol. 2, 701-743.

Kilmartin, J. The Eucharist in the West: History and Theology, Collegeville, 1998.

Kittelson, J. "Martin Bucer and the Sacramentarian Controversy: the Origins of his Policy of Concord." ARG 64 (1973):166-183.

Koch, Karl. Studium pietatis: Martin Bucer als Ethiker. Beiträge zur Geschichte und Lehre der Reformierten Kirche, 10. Neukirchen-Vluyn, 1962.

Köhn, Mechtild, Martin Bucers Entwourf einer Reformation des Erzstiftes Köln: Untersucbung der Entstebungsgeschichte und der Theologie des Einfältiges Bedenkens von 1543. Wittenberg, 1966.

Koopmans, Jan. Das altkirchlicbe dogma in der Reformation. Transl. H. Quistorp. Beiträge zur evangelischen Theologie, 22. Munich, 1955.

Kretschmar, K. "Realpräsenz und T'ransubstantiation: der Reichstag von Regensburg 1541 und ökumenische Konsensusdokumcnte der Gegenwart." In Praesentia Cbristi: Festschrift Johannes Betz zum 70. Geburtstag dargebracht von 
Kollegen, Freunden, Scbülorn, ed. I. Lies, 208-239. Düsseldorf, 1984.

Kricger, Christian \& Marc Lienhard, ed. Martin Bucer and Sixteenth Century Europe: Actes du Colloque de Strashourg (28-31 août 1991). 2 v. SMRT, 52-53. Leiden, 1993.

Krüger, Friedhelm. "Bucer und Erasmus." In Martin Bucer and Sixteenth Century Europe, ed. Krieger, vol. 1, 583-594.

Lane, Anthony N.S. John Calvin: Student of the Church Fathers. Edinburgh, 1999.

Laenmer, Hugo. Die vortridentinisch-katholische Theologie des Reformations-zeitalters aus den Quellen Dargestellt. Berlin, 1858.

Le Goff, Jacques. La naissance du Purgatoire. Paris, 1981.

Lepin, M. L'idée du sacrifice de la messe d'après les théologiens depuis l'origine jusqu'à nos jours. Paris, 1926.

Lewis, Keith D. "Unica oblatio Cbristi: Eucharistic Sacrifice in the First Ziirich Disputation." Renaissance and Reformation 17, no. 3 (1993):19-41.

Lienhard, Marc. "Thomas Murner et la Reformation." Chap. in Un temps, une ville, une Réforme: la Reformation à Strassbourg: Studien zur Reformation in Sirassburg, 51-62. Aldershot, 1990.

Lipgens, Waltcr. Kardinal Johannes Gropper, 1503-1559 und die Anfänge der Katholischen Reform in Deutschland. Münster, 1951.

McGrath, A. The Intellectual Origins of the European Reformation. Oxford, 1987.

Massaut, J. P. Critique et tradition à la veille de la Réforme en France. Paris, 1974.

Matheson, Peter. Cardinal Conlarini at Regensburg. Oxford, 1972.

--- "Martin Bucer and the Old Church" In Martin Bucer: Reforming Church and Community, ed. Wright, 5-16.

--- "Martyrdom or Mission? a Protestant Debate," ARG 80 (1989):154-171.

Mehlhausen, J. "Die Abendmahlsformel des Regensburger Buches." In Studion zur Geschichte und Theologie der Reformation: Festschrift für Ernst Bizer, ed. L. Abramowski and G. F. G Goeters, 189-211. Neukirchen-Vluyn, 1969.

Millet, Olivier. Correspondance de Wolfgang Capiton (1478-1541): analyse et index (d'après le "Thesaurus Baumianus" et autres sources). Publications de la Bibliothèque Nationale et Universitaire de Strasbourg. Strasbourg, 1982.

Miiller, Gertard. "Landgraf Philipp von Hessen und das Regensburger Buch." In Bucer und seine Zeit, ed. De Kroon, 101-116. VIEGM, 80. Wiesbaden, 1976.

Müller, Johannes. Martin Bucers Hermentik. Quellen und Forschungen zur Reformationsgeschichte, 32. Gütersioh, 1965.

Oberman, Heiko. The Forernnners of the Reformation: the Shape of Late Medieval Thought Illustrated by Key Documents. Transl. by Paul L. Nyhus. London, 1967. 
-_- The Harvest of Medieval Theology: Gabriel Biel and Late Medieval Nominalism. Cambridge, Mass., 1963.

Ölkumenischer Arbeitskreis cvangelischer und katholischer Theologen. "Das Opfer Jesu Christi und der Kirche." In Das Opfer Jesu Cbristi und sein Gegenweart in der Kirche: Klärungen zum Opfercharakter des Ilerrenmables, ed. K. Lehmann \& E. Schlink. Dialog der Kirchen, 3. Freiberg, 1983.

Old, Hughes Oliphant. The Patristic Roots of Reformed Worship. Zürcher Beiträge zur Rcformationsgeschichte, 5. Zurich, 1975.

Olivier, Daniel. "Melanchthon et la doctrine du sacrifice de la messe." In Penser la foi: recherches en théologie aujourd'bui: mélanges offerts à Joseph Moingt, ed. J. Doré \& C. 'Theobald, 601-614. Paris, 1993.

Pabel, Hilmar, ed. Erasmus' Vision of the Church. Sixteenth Century Essays and Studies, 33. Kirksville, Mo., 1995.

-2.- "The Peaccful People of Christ: the Irenic Ecclesiology of Erasmus of Rotterdam." In Erasmus Vision of the Church, ed. Pabel, 57-93.

Payne, John, Erasmus: bis Theology of the Sacraments. [s.n.], 1970.

Pffnür, Vincenz. "Die Eingigung bei den Religionsgesprächen von Worms und Regensburg, 1540/41: eine Täuschung?" In Die Religionsgespräche der Reformationszeit, cd. G. Müller, 55-88. SVR, 191. Gütersloh, 1980.

Pollet, Jacques V. Julius Pfing (1499-1564) et la crise religieuse dans l'Allemagne du xvi siècle: essai de synthèse et théologique. SMRT, 45. Leiden, 1990.

-- Martin Bucer: études sur la correspondance avec de nombreux textes inédits. $2 \mathrm{v}$. Paris, 1962.

- Martin Bucer: études sur les relations de Bucer avec les Pays-Bas, l'Électoral de Cologne et l'Allemagne du Nord. 2 v. SMRT, 33. Leiden, 1985.

Power, David. "The Priestly Prayer: the 'T'ridentine Theologians and the Roman Canon." In Fountain of Life, ed. G. Austin, 134-164. Washington D.C., 1981.

--- The Sacrifice We Offer: the Tridentine Doctrine and its Re-interpretation. Edinburgh: T. \& T. Clark, 1987.

Rudolf Padberg. "Luther und der Canon Missae." Catbolica 37, no. 4 (1983):288305.

Rice, E. "The Renaissance Idea of Christian Antiquity: Humanist Patristic Scholarship." In Renaissance Humanism: Foundations, Forms and Legacy, ed. A. Rabil, 17-26. Philadelphia, 1988.

Ritter, Adolf M. "Dionysius Areopagita im 15. und 16. Jahrhundert." In Auctoritas Patrum, ed. Grane, 143-158.

Rutherford, D. "Gratian's Decretum as a Source of Patristic Knowledge in the Italian Renaissance: the Example of Tomoteo Maffei's In sanctam rusticitatem 
(1454)" In Reception of the Cburch Fathers, ed. Backus, vol. 2, 511-535.

Schindler, Alfred. Zwingli und die Kirchenväter: Zurich, 1984.

Schulze, Manfred. "Martin Luther and the Church Fathers." In Reception of the Church Falbers, ed. Backus, vol. 2, 579-626.

Schüssler, Hermann. Der Primät der Heiligen Schrift als theologisches und kanonistisches Problem im Spätmittelalter. VIEGM, Bd. 86. Wiesbaden, 1977.

Stinger, Charles. "Italian Renaissance Learning and the Church Fathers." In Reception of the Cburch Fathers, cd. Backus, vol. 2, 473-510.

Stupperich, R. "Bibliographia Buceriana" in H. Bornkamm, Martin Bucers Bedeutung für die earopäische Reformationsgeschichte, 37-96. Gütersloh, 1952.

-.- Der Humanisnus und die Wiedervereinigung der Konfessionen. SVR, 160. Leipzig, 1936.

Tavard, George H. Holy Writ or Holy Church: the Crisis of the Protestant Reformation. London, 1959.

Thompson, Thomas A. The Ecclesiology of Georg Witzel, 1501-1573: a Study in the Catbolic Reformation. Ph.D. diss., University of Pittsburgh, 1977.

'Trusen, W. Um die Reform und Einheit der Kirche: zum Leben and Werk Georg Witzels. Katholisches Leben und Kämpfen im Zeitalter der Glabuensspaltung, no. 14. Münstcr i. Westfalen, 1957.

Tylenda, Josephy. "A Eucharistic Sacrifice in Calvin's Theology." Theological Studies 37 (1976):456-466.

Van de Poll, Gerrit Jan. Martin Bucer's Liturgical Ideds' the Strussburg Reformer and bis Connection with the Liturgies of the Sixteenth Century. Van Gorcum's Theologische Bibliotheek, no. 27. Assen, 1954.

Van 't Spijker, Willem. The Ecclesiastical Offices in the Thought of Martin Bucer. Transl. J Vricnd \& L. Bierma. SMRT, 57. Leiden, 1996.

Varrentrapp, C. Hermann von Wied und sein Reformationswersuch in Köln: ein Beitrag zur deutschen Reformationsgeschichte. Leipzig, 1878.

Vogel, Cyrille. "Une mutation cultuelle inexpliquée: le passage de l'eucharistie communautaire à la messe privée." Revue des sciences religicuses 54 (1980): 231250.

Wartenberg, Gïnther, "Die Leipziger Religionsgespräche von 1534 und 1539: Ihre Bedeutung für die sächsisch-albertinische Innenpolitik und für das Wirken Georgs von Karlowitz." In Die Raliyionsyespräche der Reformationszeit, ed. G. Müller, 35-41. SVR, 191. Gütersloh, 1980.

Werbeck, W. "Valor et applicatio missae: Wert und Zuwendung der Messe im Anschluß an Johannes Duns Scotus." ZThK 69 (1972):163-184.

Wright, David. "Martin Bucer; Ecumenical Theologian." In Common Places of 
Martin Bucer. Appleford, 1972. 17-71.

--- ed. Martin Buccr: Reforming Church and Community. Cambridge, 1994.

Zur Mühlen, Karl-Heinz. "Martin Bucer und das Religiongespräch von Hagenau und Worms, 1540/41." In Martin Bucer and Sixteenth Century Europe, ed. Krieger, wol. 2, 659-669. 